\title{
Physico-chemical characterisation of material fractions in household waste Overview of data in literature
}

\section{Götze, Ramona; Boldrin, Alessio; Scheutz, Charlotte; Astrup, Thomas Fruergaard}

Published in:

Waste Management

Link to article, DOI:

10.1016/j.wasman.2016.01.008

Publication date:

2016

Document Version

Peer reviewed version

Link back to DTU Orbit

Citation (APA):

Götze, R., Boldrin, A., Scheutz, C., \& Astrup, T. F. (2016). Physico-chemical characterisation of material fractions in household waste: Overview of data in literature. Waste Management, 49, 3-14.

https://doi.org/10.1016/j.wasman.2016.01.008

\section{General rights}

Copyright and moral rights for the publications made accessible in the public portal are retained by the authors and/or other copyright owners and it is a condition of accessing publications that users recognise and abide by the legal requirements associated with these rights.

- Users may download and print one copy of any publication from the public portal for the purpose of private study or research.

- You may not further distribute the material or use it for any profit-making activity or commercial gain

- You may freely distribute the URL identifying the publication in the public portal 


\title{
Physico-chemical characterisation of material fractions in household waste: overview of data in literature
}

\author{
Ramona Götze, Alessio Boldrin, Charlotte Scheutz, Thomas \\ Fruergaard Astrup
}

Department of Environmental Engineering

Technical University of Denmark

Kgs. Lyngby, Denmark

"NOTE: this is the author's version of a work that was accepted for publication in Waste Management journal. Changes resulting from the publishing process, such as peer review, editing, corrections, structural formatting, and other quality control mechanisms may not be reflected in this document. Minor changes may have been made to this manuscript since it was accepted for publication.

A definitive version is published in Waste Management, vol 49, pp 3-14, doi: 10.1016/j.wasman.2016.01.008" 


\begin{abstract}
State-of-the-art environmental assessment of waste management systems rely on data for the physico-chemical composition of individual material fractions comprising the waste in question. To derive the necessary inventory data for different scopes and systems, literature data from different sources and backgrounds are consulted and combined. This study provides an overview of physico-chemical waste characterisation data for individual waste material fractions available in literature and thereby aims to support the selection of data fitting to a specific scope and the selection of uncertainty ranges related to the data selection from literature. Overall, 97 publications were reviewed with respect to employed characterisation method, regional origin of the waste, number of investigated parameters and material fractions and other qualitative aspects. Descriptive statistical analysis of the reported physico-chemical waste composition data was performed to derive value ranges and data distributions for element concentrations (e.g. Cd content) and physical parameters (e.g. heating value). Based on 11,886 individual data entries, median values and percentiles for 47 parameters in 11 individual waste fractions are presented. Exceptional values and publications are identified and discussed. Detailed datasets are attached to this study, allowing further analysis and new applications of the data.
\end{abstract}




\section{Introduction}

State-of-the-art environmental assessment of waste management systems rely on data for the physico-chemical composition of individual material fractions comprising the specific waste (e.g. Laurent et al., 2014; Astrup et al., 2015). Emissions of metals from thermal treatment of waste depend on the metal content of the waste materials received at the waste incinerator (e.g. Brunner and Rechberger, 2014; Astrup et al., 2011; Morf et al., 2000). The composition of compost after aerobic degradation of organic waste is affected by the purity of the input organic waste to the composting facility (Andersen et al., 2010). Similarly, unwanted substances in waste paper collected for recycling may affect the recyclability of the paper (e.g. Pivnenko et al., 2015). Decision support tools like life cycle assessments (LCA), as well as substance flow analysis (SFA) and material flow analysis (MFA), apply waste characterisation data as input for modelling of waste management systems and individual waste technologies, for example, to identify emission hotspots, dissipation of valuable resources, and to assess the environmental consequences of potential new waste management initiatives, e.g. new source-segregation schemes affecting the material composition of existing waste incinerators, additional pre-treatment of organic waste fractions prior to composting, or isolation and removal of potential contaminated material fractions from waste flows. Without data for the physico-chemical composition of these individual material fractions, the environmental consequences of such management initiatives cannot be systematically estimated and evaluated, and emissions from the waste treatment processes cannot be tracked back to individual waste material fractions (Astrup, 2011; Manfredi et al., 2010, 2011; Rotter, 2004).

Due to the inherent heterogeneity of waste materials as well as temporal and spatial variability, representative sampling and analysis of waste samples is challenging, labour intensive and costly. Consequently, life cycle assessment of waste management technologies and systems are most often based on literature waste characterisation data (e.g. Aye and Widjaya, 2006; Cherubini et al., 2008; Fruergaard and Astrup, 2011; Arena and $\mathrm{Di}$ Gregorio, 2014). While selection of these modelling input data may significantly affect the outcome of such studies (e.g. Slagstad and Bratteb $\varnothing, 2013$; Clavreul et al., 2014; Laurent et al., 2014), very little attention is devoted to the selection of data and the type of literature sources (e.g. focus and origin of the studies providing the waste characterisation data, sampling and analytical methods applied, data coverage, etc.). As such, little guidance is available for LCA practitioners for selection of waste characterisation data and/or for evaluation of case-specific data in the perspective of data available in literature. An overview of existing characterisation data quantifying data variability for different physico-chemical parameters in individual waste material fractions, and linking critical values to specific publications, sub-fractions, geographical scopes and characterisation methods is important to support LCA practitioners in making an informed choice for their inventory data. Such an overview has not been provided previously.

A variety of waste characterisation methods have been developed, however, no international consensus has been achieved so far (Dahlén and Lagerkvist, 2008). From a more generic perspective, Brunner and Ernst (1986) defined three approaches for waste characterisation: i) direct waste analysis, ii) waste product analysis, iii) market product analysis. Direct waste analysis examines individual samples of waste materials by chemical analysis. Waste product analysis (also referred to as indirect waste analysis) combines chemical analysis of output materials from waste treatment facilities (e.g. incineration residues, compost or mechanically sorted waste fractions) with mass and substance balance calculations to determine the chemical composition of the input material. A key advantage of waste product analysis over direct analysis is the minimisation of 
uncertainties associated with sampling as samples of residues from incineration represent larger waste quantities entering the incinerator (e.g. Brunner and Ernst, 1986; Astrup et al., 2011). On the other hand, waste product analysis may provide limited information about individual material fractions within waste flows (i.e. waste product analysis involving waste incinerators may only provide data for the combined waste input flow, rather than the individual materials in the waste), while direct waste analysis may address the specific material fractions within mixed waste flows (e.g. household waste). In both cases, however, high quality characterisation data require considerable attention to sampling and sample handling (e.g. Gy, 1998; Morf and Brunner, 1998; Petersen et al., 2004). Market product analysis estimates the waste composition based on national statistics on production and consumption of goods (Brunner and Ernst; 1986) and is classically used to quantify material and substance flows (MFA/SFA) within a country. As we aimed at directly reported element concentrations and using the later explained search criteria no studies using this approach could be identified, market product analysis is not further addressed in this paper.

Both direct and indirect waste analysis requires considerable efforts for capturing spatial and temporal variation in the physico-chemical properties of waste materials. This may result in limited availability of waste characterisation data suitable for specific assessment purposes. The importance for LCA studies of applying appropriate waste composition data reflecting the spatial and temporal scope of the assessment has been pointed out in several cases (e.g. Clavreul et al., 2012; Fruergaard and Astrup, 2011). However, in a review of LCA studies of waste-to-energy technologies, Astrup et al. (2015) reported that only $44 \%$ of studies in literature provided information about the chemical composition of the addressed waste (and only $60 \%$ of these specified the origin of the data). Despite the potential challenges related to data quality, data coverage, characterisation approaches, etc., state-of-the-art waste LCA modelling most often involves selection and combination of various data sources for establishment of the needed input data (e.g. Fruergaard and Astrup, 2011). Potentially, this may involve a mixture of datasets from different publications based on a variety of waste characterisation methods as well as varying temporal and regional scopes (e.g. Aye and Widjaya, 2006; Cherubini et al. 2008; Arena and Di Gregorio, 2014). To properly address uncertainties in LCA modelling of waste technologies, a basis for identifying appropriate uncertainty ranges reflecting the choice of physico-chemical waste composition data is needed. A quantitative overview of value ranges and variability of waste characterisation data in literature, including the variations due to involved methods, geographical scopes, waste types, and parameters, is fundamental in this context.

The overall aim of the paper is to provide an overview of available data on the physical and chemical composition of individual waste material fractions in literature. This includes the following, more specific objectives: i) systematically collecting relevant waste characterisation data in literature for materials in household waste, or materials very likely to be found in household waste, ii) evaluating key aspects of the involved literature (e.g. region, sampling point, type of waste materials, characterisation method, analytical method), and iii) quantifying value ranges and data distributions for selected parameters (e.g. energy, nutrient and heavy metal contents) for individual waste material fractions based on the collected data. The provided value ranges include all types of uncertainty and variability related to acquisition of the waste characterisation data in literature (i.e. temporal and spatial variation, as well as uncertainties related to the waste characterisation approach, sampling and chemical analysis). The value ranges thereby represent full error margins associated with the "blind" selection of data from literature. Finally, gaps in existing literature and data availability for individual regions, the included parameters and waste material fractions are identified. 


\section{Methods}

\subsection{Literature selection}

Literature indexed and accessible through online search platforms (e.g. Web of Science, Google Scholar and ScienceDirect; a list of keywords is provided in Table $1 \mathrm{~A}$ in Appendix A) was included. Only literature published in English, German, Dutch, French and Italian was assessed. Publications were selected according to the following criteria:

I. the publication was published between 1990 and 2014;

II. the publication addressed the characterisation, management or treatment of municipal solid waste or waste materials that are very likely to be found in household waste and waste with comparable properties;

III. the publication presented physico-chemical data for heating value, ash content and/or the elemental composition of distinct waste materials or mixed waste fractions from household waste or comparable sources.

To ensure that the results would be relevant for a broad range of waste management assessment scenarios, characterisation data on mechanically processed waste were excluded (e.g. plastics sorted in a MRF from co-mingled fraction). For the same reason, publications investigating "artificial waste samples" (i.e. non-waste materials or mixtures of non-waste materials) were also excluded. Only literature published after 1990 was included to ensure relevance for current and near-future waste compositions. The reviewed publications included peer-reviewed journal articles, accessible theses, and online available reports from governmental institutions and other organizations. When the presented data originated from other articles, reports or theses, the primary source was identified and, if accessible, added to the collection instead of the secondary source. When the primary source could not be accessed, the secondary data source was used. If the provided characterisation data were published only in figures, the original data were requested from the authors. If the authors could not be contacted or did not reply, the values were estimated based on the graphics via digital measuring tools.

\subsection{Data extraction from literature}

The waste materials addressed in literature were categorised as one of 11 predefined waste material fractions: mixed organic waste, food waste, gardening waste, paper and cardboard, composites, plastics, combustibles, metal, glass, inert or mixed waste. Hazardous and electronic waste fractions were excluded from the scope of the study. A more detailed description of the 11 defined waste material fractions is provided in Table A2 in Appendix A.

Data were considered single database entries when the reported values represented individual samples in time (e.g. season or any other occasion) and location (e.g. treatment facility, municipality orsocio-economic factors in the collection area). The waste characterisation data found in literature were reported in several ways: i) single values, ii) value ranges, iii) median values with a percentile, or iv) mean values with a variation (e.g. 50.2). To allow comparison, database entries were converted into individual data points using the following approach: i) single values were included as individual data points; ii) value ranges or repeated measurements of the same material sample were included as two data points equivalent to the higher and lower end of the range; iii) medians with percentiles were included as three data points: the median and reported percentiles as one lower and one upper value; iv) mean values with a variation (regardless of probability distribution or level of confidence) were included as three data points: mean, mean minus the variation and mean plus the variation. The abovementioned approach thereby attributed more "weight" to data from studies reporting median/mean values with uncertainty ranges as opposed to studies reporting only single values. This was done tacitly 
acknowledging that studies providing median/mean values with ranges also offered more "information" than associated with single values. Negative values were discarded (as negative concentrations do not exist); e.g. if a mean value minus the variation resulted in a negative value.

\subsection{Data evaluation}

While the collected literature data represented a wide variety of sources and approaches, the intention was not a priori to discard specific data types or analysis approaches, but rather to provide an overview of the full range of data available. This approach tacitly assumed that published research may provide useful information, regardless the "quality" of the reporting and the specific experimental methods applied. Based on the set of database entries collected from literature, median concentrations and $10 \%, 25 \%, 75 \%$ and $90 \%$ percentiles were calculated for the available physico-chemical parameters and waste material fractions. The difference between the $25 \%$ percentile (lower quartile) and the $75 \%$ percentile (upper quartile) is called the "interquartile range". Values outside the interval between the upper quartile, plus the interquartile range multiplied by a factor of 1.5 and the lower quartile minus the interquartile range multiplied by a factor of 1.5, were considered as outliers relative to the remaining literature data.

If results below the detection limit were reported as semi-quantitative information, i.e. if the exact value of the detection limit was provided, this value was included as a database entry. If data were reported on a wet basis, the dry-based equivalent was calculated using the reported moisture contents of the materials. Data on ash contents were derived from reported data for the volatile solid content (VS), following the assumption that the sum of ash contents and volatile solid contents add up to $100 \%$.

\section{Results and Discussion}

\subsection{Literature overview}

\subsubsection{Number and type of publications}

Overall, 101 publications were identified as relevant according to the selection criteria. Of these, only 97 were suitable for further evaluation (see Table A3 in Appendix A for a complete list of publications): in one publication (LfU, 2002) compositional values could not be extracted because of the quality of the presented figures, while three other publications (Morf et al., 2000; Riber, 2005; Øygard et al., 2004) only provided data based on wet weight of the waste materials, without reporting any moisture content. As the comparison of dry- and wet weight-based values is not meaningful and most data were reported per dry weight, data from these three publications were excluded from further evaluation. Overall, the amount of data based on wet weight corresponded to only $0.5 \%$ of all collected database entries. While many publications (19\%) did not explicitly state whether the presented values were based on dry or wet material weight, studies where the data appeared to be based on dry weight were nevertheless included - despite the risk of including some wet-based values. The following results and discussion address the 97 publications from which data could be extracted and included in the evaluation.

\subsubsection{Types of publications and geographical origin}

The selected 97 publications comprised 65 articles published in ISI journals, 12 reports, nine articles in other journals or conference proceedings, five books, four PhD theses and two Bachelor theses. About half of the selected publications were published after 2006. English was the primary language (83 publications), but six publications in German, four in Italian, three in French and one in Dutch were also identified. Overall 11,886 database entries were collected. The majority of waste characterisation data were 
obtained for European waste. Overall, $42 \%$ of the publications and $58 \%$ of the database entries described waste from Europe (Figure 1).

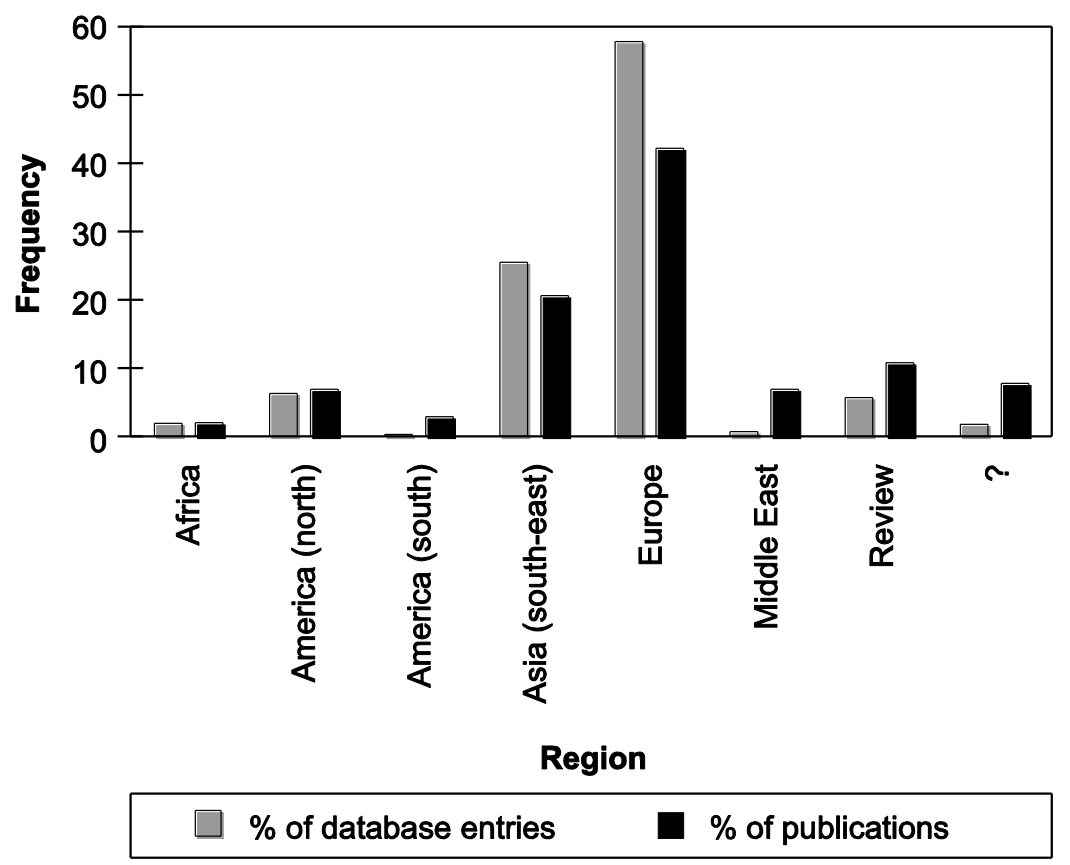

Figure 1: Data availability per region based on 97 publications containing a total of 11,886 database entries

Within Europe, most data were found for central European waste ${ }^{1}(53 \%)$ and the least for southern European waste ${ }^{2}(11 \%)$. Waste characterisation data from northern Europe $^{3}$, including Greenland, comprised $37 \%$ of the European data. The second largest amount of publications (20\%) and database entries (25\%) was found for waste from Asia. Very few publications and data were found for waste in South America (three publications) or the Middle-East, including India (four publications). Eleven publications reported reviewed data that could not be associated with a specific region, and eight publications did not report the regional origin of the investigated waste materials at all. Overall, the countries for which most characterisation data were found were China, Denmark and Germany, contributing with $25 \%, 18 \%$ and $9 \%$ of all database entries, respectively. Notable publications from China were: Zhang et al. (2008) and Zhou et al. (2014), the former published characterisation data only in figures but nevertheless provided an extensive dataset - upon request - describing the heavy metal contents for monthly sampled waste fractions. Zhou et al. (2014) provided a comprehensive review of waste characterisation data from publications on Chinese waste (although we suspect that some of these reviewed publications published in Chinese included simulated waste, any definitive conclusions were not possible based on the available information). Although the overall amount of data

\footnotetext{
${ }^{1}$ Central Europe: Austria, Czech Republic, France, Germany, Netherlands, Switzerland, United Kingdom

2 Southern Europe: Greece, Italy, Spain

${ }^{3}$ Northern Europe: Denmark, Finland, Greenland, Norway, Sweden
} 
found appears to be extensive when subdividing the datasets from every country by physico-chemical parameters and waste material fraction clear limitations for multifactorial statistical data analysis become obvious due to data paucity as presented for the example of $\mathrm{Cd}$ in Table 1.

Table 1: Collected database entries for the element $\mathrm{Cd}$ by waste material fraction and region. Similar information for all parameters found is provided in Appendix A (Tables A6-12.

\begin{tabular}{|c|c|c|c|c|c|c|c|c|}
\hline Waste Fraction & $\begin{array}{l}\text { ○ } \\
\text { 을 } \\
\text { ய }\end{array}$ & $\frac{\pi}{4}$ & $\frac{d}{d}$ & $\frac{\mathbb{8}}{\frac{0}{2}}$ & 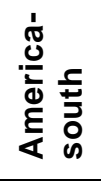 & 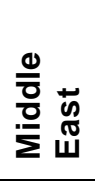 & 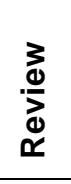 & r. \\
\hline Mixed organics & 32 & 2 & & & & & 3 & 1 \\
\hline Food waste & 47 & 48 & 3 & & & & & \\
\hline Gardening waste & 17 & & 2 & & & & & \\
\hline Paper and cardboard & 36 & 24 & 6 & & & & 3 & 3 \\
\hline Composites & 10 & & & & & & & 1 \\
\hline Plastic & 35 & 24 & 5 & & & & 5 & 10 \\
\hline Combustibles & 59 & 48 & 5 & & & & 11 & 5 \\
\hline Metal & 30 & 24 & 5 & & & & 1 & 1 \\
\hline Glass & 15 & 25 & 1 & & & & 1 & 1 \\
\hline Inert & 17 & 25 & 1 & & & & 2 & 1 \\
\hline Mix & 31 & 25 & & 15 & & 6 & 2 & 1 \\
\hline
\end{tabular}

As described more in detail in chapter 3.1.5, $\mathrm{Cd}$ is the parameter we found most data for. While for each fraction a substantial number of database entries was collected, many data gaps appear when sorting the data by an additional factor, such as e.g. macro-regions. Thus, a consistent statistical comparison of physico-chemical properties in individual waste fractions by region or country is not possible based on the current database. More detailed information on the regional data availability for every parameters and material combination is provided in Appendix A (Tables A6-12).

\subsubsection{Data presentation and focus of studies}

In 53 out of 97 of the reviewed publications, the characterisation data were presented in the results section of the study, in 16 publications in the methods section, in three publications in the introduction and in four publications in the appendix, while for one study the respective table was not cross-referenced to any text section. Twenty (20) publications did not follow the classic scientific article structure (i.e. introduction, methods, results, etc.) so that the data presentation could not be clearly associated to any of those types. Only 38 out of 97 publications focused solely on the characterisation of the waste materials, whereas in 59 publications characterisation data were presented as part of other objectives. This indicates that not all publications offering waste data had waste characterisation as primary focus, but rather focused on other aspects such as evaluation of specific waste treatment processes. As such, these studies may also offer valuable waste characterisation data. On the other hand, such studies provided less information about sampling, analytical methods and the origin of the waste. Overall, we found that 40 out of the 97 publications provided no information about where and how the samples were obtained, and for additional eight publications the information was incomplete. 
Thirteen (13) publications provided all or parts of their characterisation data in figures. In two cases, the authors responded to our contact and provided the related dataset. For the other publications, data were approximated from the figures as previously described.

\subsubsection{Characterisation approaches}

As already described in the introduction, waste characterisation methods can be classified into three categories (Brunner and Ernst, 1986); two of these are addressed in this overview: direct waste analysis and waste product analysis (or indirect waste analysis). The dominant type of characterisation method used in the reviewed publications was direct waste analysis, accounting for $64 \%$ of the evaluated database entries (Figure 2). Six publications ( $2 \%$ of database entries) used waste product analysis or SFA to estimate elemental concentrations in the input waste, and in five publications outputs from waste incinerators were investigated for this purpose (Astrup et al., 2011; Belevi and Moench, 2000; Morf, 2006; Morf et al., 2013; SAEFL, 2004). One publication used secondary data for multiple waste treatment facilities to track substance flows back to the combined MSW (Korzun and Heck, 1990).

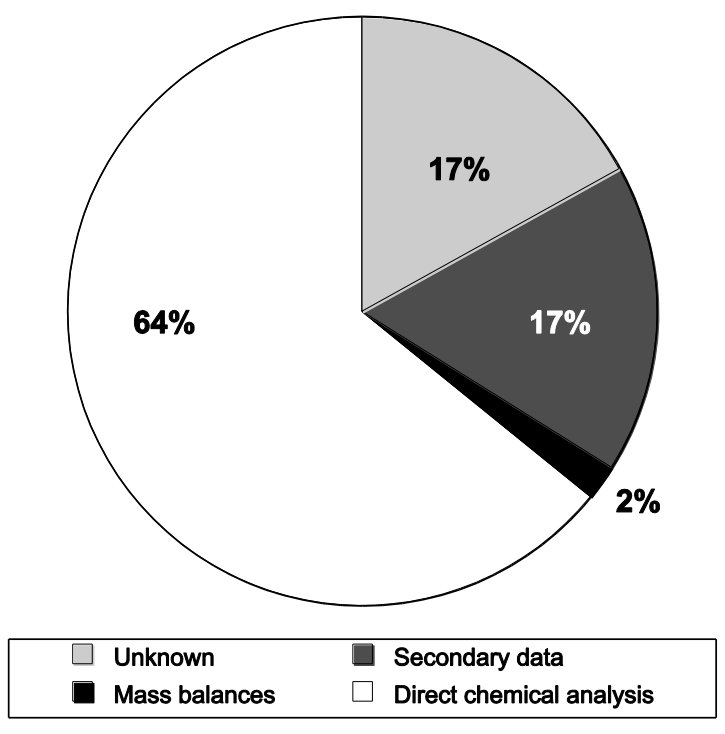

Figure 2: Prevalence of characterization methods, expressed as share (\%) of 11,886 database entries

The employed characterisation approaches differed, however, substantially between the individual parameters. Detailed information on the frequency of the employed approaches for every parameter is available in Table A5 in Appendix A. For heavy metals and toxic elements, on average $76 \%$ of the data points for each element originated from direct chemical analysis, whereas only $6 \%$ originated from mass balance calculations and $8 \%$ from secondary data reporting. For $9 \%$ of the data for heavy metals, the characterisation method or original source was not reported. For nutrients and organic elements, on average $61 \%$ of the data points for the individual parameters were obtained using direct waste analysis. Only $1 \%$ of the data for $\mathrm{C}, \mathrm{H}, \mathrm{S}$ and $\mathrm{O}$ were based on mass balance calculations, while for $\mathrm{N}$ no values at all were obtained via waste product analysis. For $\mathrm{P}, \mathrm{K}, \mathrm{Na}, \mathrm{Mg}$ and $\mathrm{Ca}$, the share of data points derived from waste products analysis was between $4 \%$ and $8 \%$, while secondary data reporting was more common for the elements $\mathrm{N}, \mathrm{C}, \mathrm{H}, \mathrm{S}$ and $\mathrm{O}$ (average $21 \%$ of the respective data sets) than for $\mathrm{P}, \mathrm{K}, \mathrm{Na}, \mathrm{Ca}$ and $\mathrm{Mg}$ (on average $7 \%$ of the respective data points). For about $20 \%$ of the data points relating to 
nutrients and $\mathrm{CHNO}$, no information on the characterisation method was provided. The reported energy contents (HHV and LHV) and ash contents were mostly obtained from experimental measurements (55-58\% of the data points), whereas waste product analysis was used only by a single publication to determine the LHV. For about $20 \%$ of the data points no information on the characterisation methods was provided, and $17-27 \%$ of the data points originated from other cited publications which were not accessible. Also, for $\mathrm{Cl}$, $\mathrm{F}$ and $\mathrm{Br}$, direct chemical analysis was the most common waste characterisation method. Many elements which have been recently under discussion because of their strategic criticality and supply risks were only investigated using waste product analysis ( $\mathrm{Bi}, \mathrm{Ga}, \mathrm{Gd}$, $\mathrm{Ge}, \mathrm{Hf}, \mathrm{In}, \mathrm{Nd}, \mathrm{Pr}, \mathrm{Pt}, \mathrm{Rb}, \mathrm{Rh}, \mathrm{Ru}, \mathrm{Ta}$ and Te). For Ag, Au, B, Li, Nb, Sc, Sn, Sr, Ti, W, Y and Zr direct chemical waste analysis was also reported by $2550 \%$ of the relevant publications.

\subsubsection{Parameters and material fractions investigated}

Most of the reviewed publications focused on specific materials found in waste (64 publications), whereas 33 publications focused on a wider range of material fractions found in MSW or household waste (HHW). Most publications investigated only a few waste fractions and a limited set of physico-chemical parameters, while publications dealing with many different material fractions and many parameters were scarce (Figure 3 ). Sixty-three (63) publications provided information for one to nine parameters, while six publications provided information only on one parameter and 15 publications investigated more than 20 parameters.

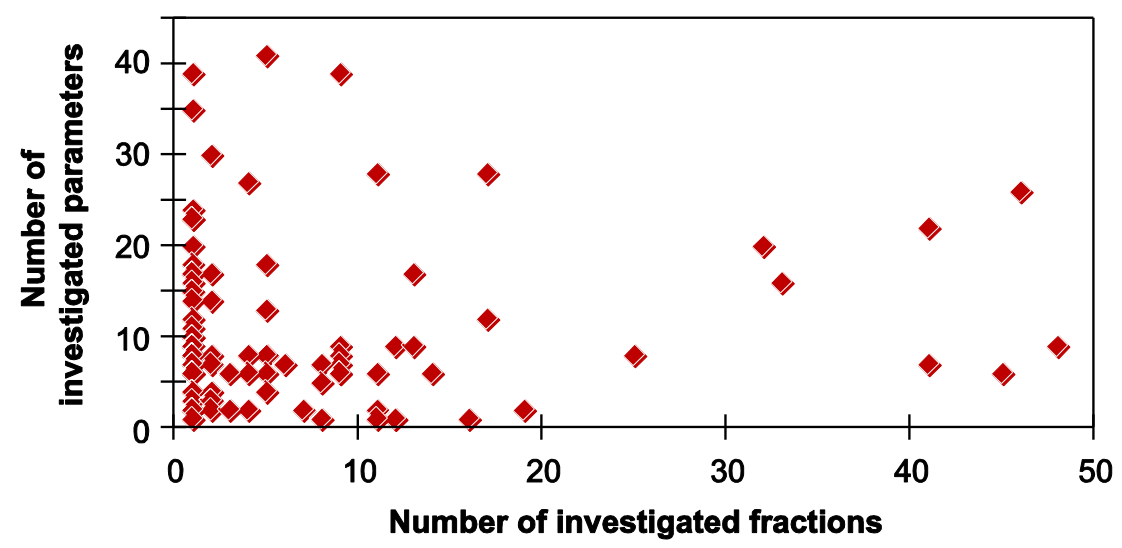

Figure 3: Overview of the reviewed 97 publications with respect to number of investigated material fractions and physico-chemical parameters.

The most parameters analysed were found in Boldrin and Christensen (2010) (41 parameters; source-segregated garden waste fractions), in Eisted and Christensen (2011) (39 parameters; Greenlandic household waste fractions) and in Morf et al. (2013) (39 parameters; MSW via waste product analysis). The most material fractions were investigated by Kost (2001) (48 fractions), Riber et al. (2009) (46 fractions), Rotter (2002) (41 fractions) and Maystre and Viret (1995) (41 fractions). The majority of publications (57) investigated fewer than five waste material fractions, while 45 publications did not subdivide the investigated waste into fractions at all. Only seven publications dealt with more than 30 distinct waste fractions. Categorising the materials investigated in the selected publications according to the 11 defined waste fractions, the most investigated material fractions were: mixed waste (49 publications), plastics (44), paper and cardboard (39), combustibles (39) and food waste (38) (Figure 4). 


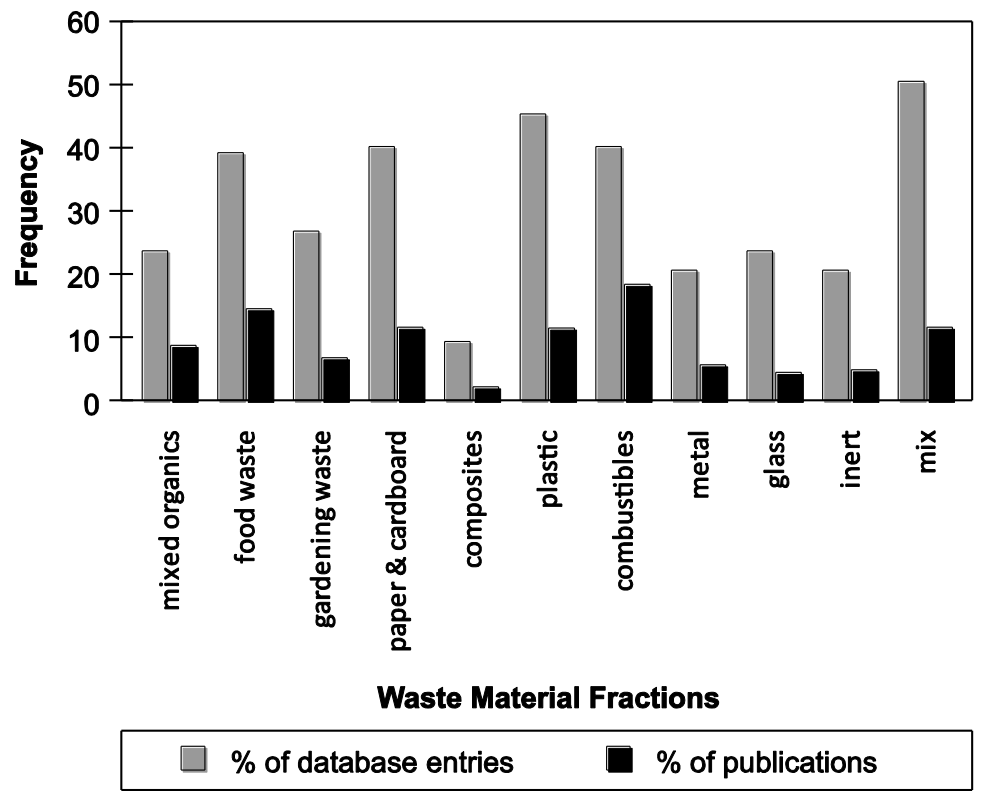

Figure 4: Data availability per waste material fraction based on 97 publications containing a total of 11,886 database entries

Only nine publications investigated composite material fractions. Publications that provided both very detailed fractions and many physico-chemical parameters were: Riber et al. (2009) (26 parameters; 46 fractions), Tchobanoglous et al. (1993) (22 parameter; 41 fractions), LfU (2003) (20 parameters; 32 fractions), Bailie et al. (1997) (16 parameters; 33 fractions) and RIVM (1999) (28 parameters; 17 fractions).

Overall, we found data for 62 parameters in waste materials. However, the number of available database entries varied significantly between parameters and waste material fractions (Figure 5). Only for about 15 parameters, data were collected across in all 11 waste materials. For 30 parameters, median values were not calculated for all material fractions due to lack of data, while for 13 parameters only a single database entry was found. The most frequently analysed parameter in the reviewed publications was $\mathrm{Cd}$ with a total of 675 database entries, followed by $\mathrm{Pb}$ ( 659 database entries) and $\mathrm{Zn}$ ( 645 database entries). Most $\mathrm{Cd}$ data were found for combustible waste (128 database entries). This suggests that the focus of many publications was quantification of trace contaminants of environmental concern. A detailed overview of the number of database entries found for all parameter-material combinations is provided in Table A4 in Appendix A.

\subsection{Value ranges and parameter-specific information}

The following sections provide an overview and discussion of the collected waste characterisation data grouped according to parameter types (heavy metals and toxic elements, nutrients and CHNO, energy related parameters, and high-tech application elements): i) an overview of data availability, ii) quantification of median concentrations and data ranges when this was possible based on the collected data, iii) discussion of exceptional observations and outliers, and iv) an overview of the analytical and characterisation methods applied. 


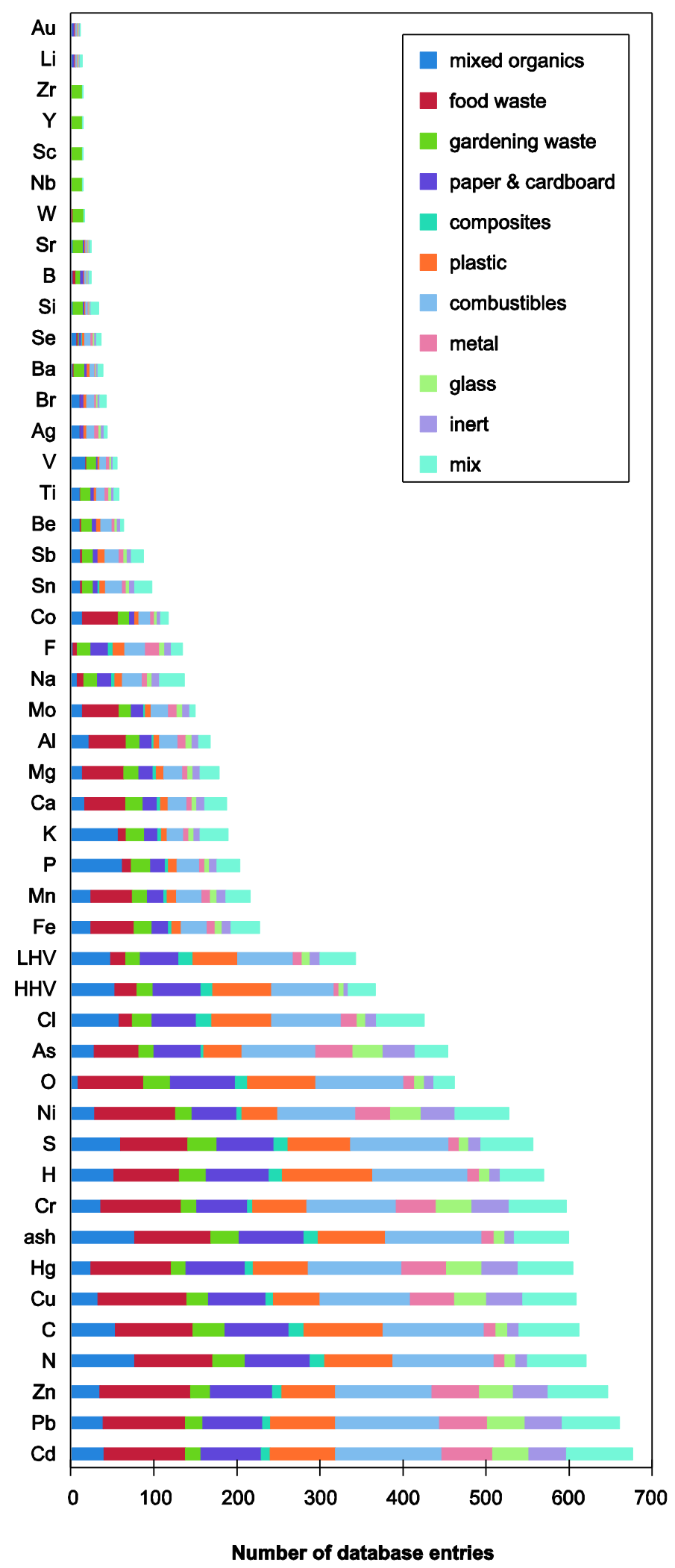

Figure 5: Collected database entries for different parameters and waste material fractions (only parameters with 10 or more database entries are displayed). 


\subsubsection{Heavy metals and toxic elements}

In following sections collected data for the elements $\mathrm{Al}, \mathrm{As}, \mathrm{Ba}, \mathrm{Be}, \mathrm{Cd}, \mathrm{Co}, \mathrm{Cr}, \mathrm{Cu}, \mathrm{Fe}$, $\mathrm{Hg}, \mathrm{Mn}, \mathrm{Mo}, \mathrm{Ni}, \mathrm{Pb}, \mathrm{Sb}, \mathrm{Tl}, \mathrm{V}$, and $\mathrm{Zn}$ are presented and discussed.

\section{Data Availability}

The best data availability was observed for $\mathrm{Cd}$ with 675 database entries, translated into 869 data points. An extensive amount of data was also found for $\mathrm{Pb}$ ( 828 data points), $\mathrm{Zn}$ (719 data points) and $\mathrm{Hg}$ (751 data points). For $\mathrm{Cu}, \mathrm{Cr}$, Ni and As, significant amounts of data were available for all waste material fractions except for composites (fewer than 10 data points). For Fe, Mn, Al, Mo and Co, we found very little data for two or more material fractions (fewer than 10 data points). Data availability for $\mathrm{Fe}$ and $\mathrm{Mn}$ in glass and composite, for Mo and $\mathrm{Co}$ in composite, and for $\mathrm{Co}$ in plastic, glass, inert, metal and paper was insufficient to provide a reliable dataset as fewer than five data points were available for each element-material combination. Moreover, all or $90 \%$ of the data points for Mo, Co and $V$ in food waste refer to values reported below the detection limit (detection limits were used as concentrations) adding uncertainty. For Be and Ba more than five data points were only available for the waste fractions combustibles and mixed waste. Only two database entries for $\mathrm{Tl}$ concentrations in mixed waste were found.

\section{Median concentrations and data ranges}

Due to the extensive amount of data involved, only selected results are discussed below. As an example, box-whisker plots and the corresponding quantiles for $\mathrm{Hg}$ concentrations are presented in Figure 6 and Table 2. Similar information for all 47 parameters can be found in Appendix B.

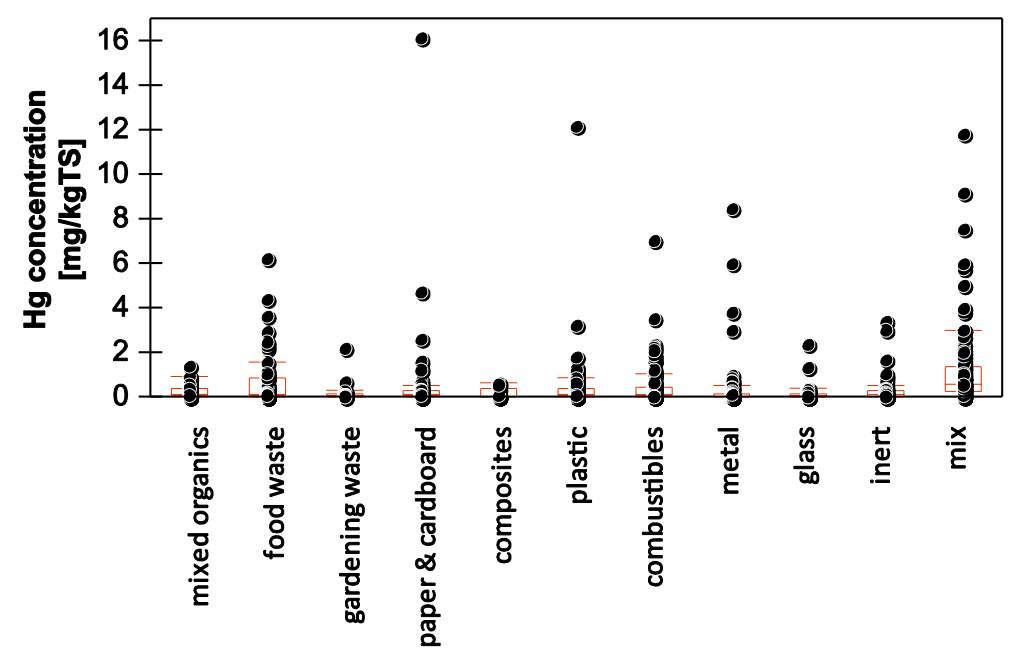

Waste Material Fractions

Figure 6: Box-whisker-plots and data points for $\mathrm{Hg}$ concentrations in different waste material fractions reported in literature. The displayed whiskers correspond to the upper quartile plus the interquartile range multiplied with the factor $\mathbf{1 . 5}$ and the lower quartile minus the interquartile range multiplied with the factor 1.5 . All values beyond these points are considered as outliers. Similar information for $\mathbf{4 7}$ parameters is available in Appendix B. 
Table 2: Quantiles of Hg concentrations (mg/kgTS) reported in literature in, "ndata": total number of data points; "n<DL": number of data points below detection limit, "food waste -alternative" presents quantiles when excluding 40 entries from WRAP (2010), which were below the detection limit. Similar information for 47 parameters is available in appendix $B$.

\begin{tabular}{llllllllll}
\hline Waste Material & & & & & & & & \\
Fraction & ndata & $\mathbf{n}_{<\mathrm{DL}}$ & Min & $\mathbf{1 0 \%}$ & $\mathbf{2 5 \%}$ & $\mathbf{M e d i a n}$ & $\mathbf{7 5 \%}$ & $\mathbf{9 0 \%}$ & Max \\
\hline organic & 34 & 4 & 0.000 & 0.020 & 0.040 & 0.100 & 0.396 & 0.850 & 1.400 \\
food waste & 99 & 41 & 0.000 & 0.020 & 0.100 & 1.120 & 2.000 & 2.000 & 6.250 \\
food waste-alternative & 59 & 1 & 0.000 & 0.000 & 0.040 & 0.140 & 0.870 & 2.310 & 6.250 \\
gardening waste & 20 & 3 & 0.000 & 0.020 & 0.023 & 0.040 & 0.198 & 0.629 & 2.170 \\
paper \& cardboard & 84 & 6 & 0.000 & 0.000 & 0.030 & 0.098 & 0.265 & 0.570 & 16.160 \\
composites & 14 & - & 0.000 & 0.000 & 0.008 & 0.025 & 0.380 & 0.595 & 0.640 \\
plastic & 89 & 3 & 0.000 & 0.000 & 0.045 & 0.130 & 0.400 & 0.891 & 12.150 \\
combustibles & 140 & 6 & 0.000 & 0.000 & 0.050 & 0.110 & 0.470 & 1.573 & 7.030 \\
metal & 60 & 5 & 0.000 & 0.000 & 0.000 & 0.025 & 0.200 & 0.790 & 8.500 \\
glass & 49 & 6 & 0.000 & 0.000 & 0.000 & 0.040 & 0.200 & 0.340 & 2.350 \\
inert & 49 & 5 & 0.000 & 0.000 & 0.015 & 0.100 & 0.285 & 0.900 & 3.420 \\
mix & 113 & - & 0.000 & 0.070 & 0.235 & 0.580 & 1.375 & 3.928 & 11.800 \\
\hline Total & 751 & 79 & & & & & & & \\
\hline
\end{tabular}

Metal waste presented the highest median concentrations for $\mathrm{Cr}, \mathrm{Cu}, \mathrm{Ni}, \mathrm{Fe}, \mathrm{Mn}, \mathrm{Al}$, $\mathrm{Mo}$ and $\mathrm{Co}$ (see Table 4), while the lowest median concentrations of $\mathrm{Cr}, \mathrm{Ni}, \mathrm{Fe}, \mathrm{Al}$ and $\mathrm{Co}$ were observed in food waste. The lowest median $\mathrm{Cu}$ concentration was found in glass and the lowest median $\mathrm{Mn}$ concentration in plastic. The lowest median $\mathrm{Cd}$ concentration was found in paper \& cardboard $(0.3 \mathrm{mg} / \mathrm{kgTS})$ and the highest in composite materials $(2.5 \mathrm{mg} / \mathrm{kgTS})$. The largest data variation for $\mathrm{Cd}$ was found in plastic, combustibles and metals. The lowest median $\mathrm{Pb}$ concentration was found in gardening waste $(9.6 \mathrm{mg} / \mathrm{kgTS}$ ) and the highest in mixed waste $(191.9 \mathrm{mg} / \mathrm{kgTS})$. Large variations of the reported $\mathrm{Pb}$ concentration were found in metal, inert materials and combustibles. The lowest $\mathrm{Zn}$ concentration was found in glass $(55 \mathrm{mg} / \mathrm{kgTS})$ and the highest in plastic $(259 \mathrm{mg} / \mathrm{kgTS})$. For $\mathrm{Zn}$, we observed large variations in the reported concentration levels, particularly for metals, combustibles, plastic and inert waste. Surprisingly, the highest median $\mathrm{Hg}$ concentration was found in food waste $(1.12 \mathrm{mg} / \mathrm{kgTS})$ with a value twice as large as the median found for mixed waste $(0.58 \mathrm{mg} / \mathrm{kgTS})$. However, 41 out of 99 data points for $\mathrm{Hg}$ in food waste were below the detection limit (Table 2). Almost all of these semi-quantitative entries originated from WRAP (2010), reporting a rather high detection limit of $2 \mathrm{mgHg} / \mathrm{kgTS}$. Indeed, $\mathrm{Hg}$ concentrations higher than $2 \mathrm{mg} / \mathrm{kgTS}$ were reported in food waste by other publications (i.e. Zhang et al., 2008 and Ferrari et al., 1998). By excluding the entries from WRAP (2010), the median concentration in food waste was indeed much lower $(0.14 \mathrm{mg} / \mathrm{kgTS})$, but food waste still represented the second-highest median concentration after mixed waste. The lowest median $\mathrm{Hg}$ concentration was observed in metal and composite $(0.025 \mathrm{mg} / \mathrm{kgTS})$. Generally, the data for $\mathrm{Hg}$ showed large variations in all material fractions as well as many very distant outliers in high concentration levels (Figure 6).

The highest median As concentration was found in glass ( $36 \mathrm{mg} / \mathrm{kgTS}$ ) and the lowest in composites $(0.2 \mathrm{mg} / \mathrm{kgTS})$. Very large data variations were found for glass, metal and combustibles. The highest median $\mathrm{Sb}$ concentration was found in mixed waste $(63 \mathrm{mg} / \mathrm{kgTS})$ and the lowest in gardening waste $(0.04 \mathrm{mg} / \mathrm{kgTS})$.

\section{Outliers, exceptional observations and limitations of the calculated value ranges}

For some metals, the reported concentrations differed significantly between ferrous and non-ferrous material samples (Table 3 ). As expected, this was especially the case for 
the elements $\mathrm{Fe}$ and $\mathrm{Al}$, though it also applied to $\mathrm{Mn}$, $\mathrm{Co}$ and $\mathrm{Cu}$. As a consequence, data variations in metal were very large. The presented median values for $\mathrm{Fe}, \mathrm{Al}, \mathrm{Mn}, \mathrm{Co}$ and $\mathrm{Cu}$ in the general metal material fraction are therefore unlikely to represent metal waste materials which are sorted according to their iron content (e.g. by magnetic separators).

Table 3: Comparison of metal concentrations (median values, rounded to three significant digits) in metal waste fractions; ferrous metal, non-ferrous metal, and metal waste in general.

\begin{tabular}{lllll}
\hline Parameter & Unit & $\begin{array}{l}\text { Ferrous } \\
\text { Metal }\end{array}$ & $\begin{array}{l}\text { Non-ferrous } \\
\text { Metal }\end{array}$ & Metal \\
\hline $\mathrm{Fe}$ & $\mathrm{mg} / \mathrm{kgTS}$ & 885,000 & 23,900 & 493,000 \\
$\mathrm{Al}$ & $\mathrm{mg} / \mathrm{kgTS}$ & 4,880 & 689,000 & 172,000 \\
$\mathrm{Cu}$ & $\mathrm{mg} / \mathrm{kgTS}$ & 104 & 39.0 & 94.5 \\
$\mathrm{Mn}$ & $\mathrm{mg} / \mathrm{kgTS}$ & 970 & 3,040 & 1,780 \\
$\mathrm{Co}$ & $\mathrm{mg} / \mathrm{kgTS}$ & 43.5 & 18.5 & 32.0 \\
\hline
\end{tabular}

In the mixed organics fraction higher concentration levels for many elements originated from a publication of RIVM (1999), describing a green waste fraction with particle sizes of 8-20 $\mathrm{mm}$. This could be due to dust or soil which is expected to accumulate in small particle fractions. This observation should be considered when comparing waste materials which have undergone or are supposed to undergo a sieving step. In the combustible material fraction, the largest data variations and relatively high concentrations of the elements $\mathrm{Cd}, \mathrm{Zn}, \mathrm{Hg}, \mathrm{Cr}$ and $\mathrm{Sb}$ were reported for waste materials such as textiles, rubber and leather. Sanitary products and wood generally showed lower values, which were close to the $25 \%$ percentile of the combustible fraction. Some individual data points for $\mathrm{Pb}, \mathrm{Mn}$, As and $\mathrm{Co}$ in wood showed much higher concentrations than the rest of the data - very likely due to the abundance of wood preservatives in the corresponding samples (e.g. Astrup et al., 2011). High Cd, Sb and Zn concentrations in plastic could be tracked back to non-packaging plastic and plastic items (Rotter et al., 2003), and for plastic samples consisting of non-packaging material, concentrations of these elements were likely to be in the upper quartile of the provided ranges. Very high outliers for the elements $\mathrm{As}, \mathrm{Hg}, \mathrm{Ni}, \mathrm{Cr}$ and $\mathrm{Cu}$ in almost all materials, i.e. plastic, paper and cardboard, combustibles (especially textiles, leather and rubber), glass and food waste, could be tracked back to Zhang et al. (2008), whose study examined monthly samples of Chinese waste from different treatment facilities, the reported values for which showed very high variations for these elements. While this may indicate higher concentrations in Chinese waste, no other publications offered comparable repetitions in sampling and analysis of independently obtained samples for the same waste materials. For food waste, up to half or more of the values originated from detection limits. Almost all of these entries below the detection limit for food waste originated from WRAP (2010), which investigated food waste in different municipalities in Wales (UK). In the study, numerous samples were analysed, but almost all the results for heavy metals were reported below (rather high) detection limits, in particular for $\mathrm{Hg}$. As all these database entries were included in the evaluation (to reflect that a concentration below detection limit represents some level of information) with an identical value, the calculated quantiles for food waste should be used with caution. For the elements $\mathrm{Cd}, \mathrm{Pb}, \mathrm{Hg}, \mathrm{Cu}$ and $\mathrm{Ni}$ in food waste, $35-50 \%$ of the collected data points were reported below the detection limit, while for Mo, Co and $\mathrm{V}$ in food waste, the calculated quantiles were extremely uncertain, as $90-100 \%$ of the collected data points referred to measurements below the detection limit. 


\section{Characterisation and analytical methods}

On average, $49 \%$ of the publications reporting values for heavy metals and toxic elements employed a direct chemical analysis of the waste, which corresponds to $76 \%$ of the database entries. The most frequently used analytical methods were inductively coupled plasma (ICP)-based techniques (on average $71 \%$ of publications; $59 \%$ of database entries) and atomic absorption spectroscopy (AAS) with flame atomisers $(22 \%$ of publications, $28 \%$ of database entries). The X-ray fluorescence analyser (XRF) was only used to analyse $\mathrm{Cd}, \mathrm{Cu}, \mathrm{Cr}, \mathrm{Fe}, \mathrm{Mn}, \mathrm{Ni}, \mathrm{Pb}$ and $\mathrm{Zn}$, contributing between $3 \%$ and $10 \%$ of the respective datasets from direct analysis. Depending on the individual element, $24 \%$ to $100 \%$ of the data points from direct analysis were obtained with ICP-based methods. The lowest shares of data points obtained with ICP were identified for $\mathrm{Pb}(24 \%), \mathrm{Hg}(26 \%), \mathrm{Cd}(31 \%)$ and $\mathrm{Zn}(31 \%)$. Due to its special properties, different techniques were employed for $\mathrm{Hg}$ analysis: $41 \%$ of the data points from direct analysis of $\mathrm{Hg}$ were measured using atomic fluorescence spectroscopy (AFS), $20 \%$ using hydrid AAS, $8 \%$ using cold vapour AAS and only $3 \%$ using a special $\mathrm{Hg}$ analyser. For $\mathrm{Pb}, 39 \%$ of the data from direct chemical analysis were measured using flame (or not specified) AAS, $17 \%$ were measured using flameless AAS, $10 \%$ using XRF and $10 \%$ using absorptiometry. Most data from the direct analysis of $\mathrm{Cd}$ were obtained using flame AAS (47\%), though a considerable share was measured with flameless AAS (20\%).

\subsubsection{Nutrients and CHNO elements}

In the following sections collected data for the elements $\mathrm{C}, \mathrm{H}, \mathrm{N}, \mathrm{O}, \mathrm{Ca}, \mathrm{K}, \mathrm{Mg}, \mathrm{Na}, \mathrm{P}$, $\mathrm{S}, \mathrm{Se}$, and Si are presented and discussed.

\section{Data Availability}

The best data availability among nutrients and organic elements was found for $\mathrm{N}$ with 619 database entries, corresponding to 940 individual data points. An extensive amount of data was also found for C (911 data points), H (825 data points), S (766 data points) and O (699 data points). For the elements $\mathrm{P}, \mathrm{K}, \mathrm{Ca}, \mathrm{Na}$ and $\mathrm{Mg}$ only little data (10 or fewer data points) were available for the materials metal, glass and inert, while for plastic and composite waste the data availability was generally low (fewer than four data points available). The data availability for $\mathrm{Si}$ in all materials except for mixed waste and gardening waste was insufficient (less than 5 data points). Also the data availability for Se in all fractions but mixed waste was insufficient to provide a reliable dataset and about half of the existing data points were reported below the detection limit making them even less uncertain.

\section{Median concentrations and data ranges}

The highest median concentrations for $\mathrm{Ca}, \mathrm{Na}, \mathrm{Mg}$ and $\mathrm{Si}$ were found in glass, whereas $\mathrm{N}, \mathrm{C}, \mathrm{H}$ and $\mathrm{P}$ provided the lowest median concentrations in glass (Table 4). The lowest median concentrations of $\mathrm{S}, \mathrm{K}, \mathrm{Ca}, \mathrm{Na}$ and Si were found in metals, while the lowest median $\mathrm{Mg}$ concentration was found in food waste $(274 \mathrm{mg} / \mathrm{kgTS})$; the reported $\mathrm{Mg}$ concentrations in inert, metal and glass varied extensively. The highest median $\mathrm{K}$ concentration was found in inert waste $(12.6 \mathrm{~g} / \mathrm{kgTS})$, and the data variation was very large in organic, food and gardening waste. For $\mathrm{N}$ and $\mathrm{S}$ the highest median concentrations were found in food waste ( $3 \% \mathrm{TS}$ and $3780 \mathrm{mg} / \mathrm{kgTS}$, respectively) and for $\mathrm{C}$ and $\mathrm{H}$ in plastic waste (73.0\%TS and 9.7\%TS). The reported $C$ concentrations varied considerably for all waste materials, especially for food waste, plastics, combustibles and mixed waste. For $P$, the highest median concentration ( $17.9 \mathrm{~g} / \mathrm{kgTS})$ was found in mixed waste, where the largest variation among the reported concentrations was also observed. Furthermore, in the mixed organic, food waste and gardening waste fractions, large data variations for $P$ were 
observed. The highest median $\mathrm{O}$ concentration was found in paper and cardboard (41\%TS) and the lowest was found in inert waste (0\%TS). Due to a lack of data, Si concentrations could be evaluated only for mixed waste and gardening waste. The median Si concentration in gardening waste was $144 \mathrm{~g} / \mathrm{kgTS}$; however, the data reported for this fraction varied significantly.

Table 4: Overview on lowest and highest median values for 32 selected parameters in different waste material fractions. $\mathrm{Hg}^{*}$ : when excluding 40 entries from WRAP (2010) on food waste, which were below the detection limit. This matter is discussed in detail in chapter 3.2.1 and respective alternative values can be found in table 2 .

\begin{tabular}{lll}
\hline $\begin{array}{l}\text { Waste Material } \\
\text { Fraction }\end{array}$ & Highest Median & Lowest Median \\
\hline Mixed organics & - & - \\
Food waste & $\mathrm{Hg}^{*}, \mathrm{~N}, \mathrm{~S}$ & $\mathrm{Cr}, \mathrm{Ni}, \mathrm{Fe}, \mathrm{Al}, \mathrm{Co}$, \\
Gardening Waste & - & $\mathrm{Mg}$ \\
Paper \& Cardboard & $\mathrm{Pb}$ \\
Composites & $\mathrm{Cd}$ & $\mathrm{Cd}, \mathrm{Sn}, \mathrm{Ti}, \mathrm{Ag}$ \\
Plastics & $\mathrm{Zn}, \mathrm{C}, \mathrm{H}, \mathrm{Cl}, \mathrm{HHV}, \mathrm{LHV}, \mathrm{Ti}$ & $\mathrm{As}$ \\
Combustibles & - & $\mathrm{Mn}, \mathrm{Ash}$ \\
Metals & $\mathrm{Cr}, \mathrm{Cu}, \mathrm{Ni}, \mathrm{Fe}, \mathrm{Mn}, \mathrm{Al}, \mathrm{Mo}, \mathrm{Co}$, & - \\
& $\mathrm{Sn}, \mathrm{Ag}$ & - \\
Glass & $\mathrm{As}, \mathrm{Ca}, \mathrm{Na}, \mathrm{Mg}, \mathrm{Si}, \mathrm{Ash}$ & $\mathrm{Cu}, \mathrm{Zn}, \mathrm{N}, \mathrm{C}, \mathrm{H}, \mathrm{P}$, \\
& & $\mathrm{Cl}, \mathrm{F}$ \\
Inert & $\mathrm{K}$ & $\mathrm{O}$ \\
Mixed Waste & $(\mathrm{Hg})^{*}, \mathrm{~Pb}, \mathrm{P}, \mathrm{F}$ & - \\
\hline
\end{tabular}

\section{Outliers, exceptional observations and limitations of the calculated value ranges}

For $\mathrm{N}$ and $\mathrm{C}$ large data variations were observed for the combustible waste fraction. Subdividing this fraction (where possible based on the literature), it was clear that the data for sanitary products and wood had lower variability compared to textiles, rubber and leather and other small combustibles. The highest values for both elements were reported in textiles, rubber and leather. The highest $\mathrm{N}$ concentrations were found mainly for leather and the highest $\mathrm{C}$ concentrations for rubber. The highest $\mathrm{N}$ concentrations in plastic materials were reported for a polyurethane sample, reflecting the fact that urethane groups contain a nitrogen atom. However, also for mixed plastic waste, four very high and outlying concentrations were found without any plausible explanation. A distant outlier for $\mathrm{C}$ and $\mathrm{H}$ in metal could be tracked back to a sample called "metal-like foil" (Riber et al., 2009), suggesting that this sample contained some sort of plastic laminate or coating. For the elements $\mathrm{C}, \mathrm{H}, \mathrm{N}, \mathrm{S}, \mathrm{P}$ and $\mathrm{K}$, we found a considerable difference between vegetable food waste and animal-derived food waste (Table 5). 
Table 5: Comparison of nutrients, carbon, and hydrogen concentrations (median values, rounded to three significant digits) in food waste fractions: animal derived food waste, vegetable food waste, and food waste in general.

\begin{tabular}{lllll}
\hline & & $\begin{array}{l}\text { Animal-derived } \\
\text { Food Waste }\end{array}$ & $\begin{array}{l}\text { Vegetable Food } \\
\text { Waste }\end{array}$ & Food Waste \\
\hline $\mathrm{C}$ & Unit & 55.9 & 42.7 & 47.9 \\
$\mathrm{H}$ & \%TS & 8.40 & 6.60 & 6.50 \\
$\mathrm{~N}$ & $\% T S$ & 10.4 & 1.90 & 3.00 \\
$\mathrm{~S}$ & $\% T S$ & 2,290 & 3,780 \\
$\mathrm{P}$ & $\mathrm{mg} / \mathrm{kgTS}$ & 7,520 & 2,120 & 5,200 \\
$\mathrm{~K}$ & $\mathrm{mg} / \mathrm{kgTS}$ & 12,000 & 25,300 & 8,900 \\
\hline
\end{tabular}

Except for $\mathrm{K}$, the median concentrations were found to be higher in animal-derived food waste than in vegetable food waste. The $P$ and $K$ concentrations in Nigerian mixed waste, reported by Olajire and Ayodele (1998), were remarkably higher than those from other publications. In addition, high P concentrations in Indian mixed waste were reported by Das et al. (2013). Outliers for $\mathrm{K}$ and $\mathrm{Mg}$ in combustibles could be tracked back to fractions such as cigarette butts and vacuum cleaner bags. The rather "exotic" fraction called "dead animals," reported by Riber et al. (2009), which we attributed to the gardening waste material fraction, presented very high and outlying $\mathrm{Ca}$ and $\mathrm{Mg}$ concentrations. The highest $\mathrm{Na}$ and $\mathrm{Mg}$ concentrations in paper and cardboard were reported by Tchobanoglous et al. (1993), citing an inaccessible original source. The same publication reported Ca concentrations $0 \mathrm{mg} / \mathrm{kgTS}$ in paper and cardboard, which may be questionable as calcium carbonate is often used as filling material in paper production (Auhorn, 2012).

\section{Characterisation and analytical methods}

For nutrients and CHNO elements, on average $61 \%$ of the data points for the individual parameters were obtained using direct chemical analysis. Only $1 \%$ of the data for $\mathrm{C}, \mathrm{H}, \mathrm{S}$ and $\mathrm{O}$ were based on mass balance calculations, while for $\mathrm{N}$ no values were obtained via waste product analysis. For $\mathrm{P}, \mathrm{K}, \mathrm{Na}, \mathrm{Mg}$ and $\mathrm{Ca}$, the share of data points derived from waste products analysis was between $4 \%$ and $8 \%$. Secondary data reporting was more common for the elements $\mathrm{N}, \mathrm{C}, \mathrm{H}, \mathrm{S}$ and $\mathrm{O}$ (average $21 \%$ of the respective datasets) than for $\mathrm{P}, \mathrm{K}, \mathrm{Na}, \mathrm{Ca}$ and $\mathrm{Mg}$ (on average $7 \%$ of the respective data points). For about $20 \%$ of the data points for nutrients and CHNO elements, no information on the characterisation method was provided. The most common analytical method used for the analysis of $\mathrm{C}, \mathrm{H}$ and $\mathrm{O}$ was elemental analysis based on sample combustion and the detection of gaseous components, which was employed for $83 \%, 100 \%$ and $83 \%$ of the waste samples, respectively. Alternative methods for determining $\mathrm{C}$ were total organic carbon analyser (TOC) suitable for solids ( $11 \%$ of the publications) and approximation via volatile solids (6\%). Only $52 \%$ of the publications ( $82 \%$ of data points) reporting experimental values used elemental analysis to determine $\mathrm{N}$, and $48 \%$ used the Kjeldahl method. However, this corresponds only to $18 \%$ of data points, reflecting the fact that the Kjeldahl method is a very time-consuming procedure. For the determination of $S, 40 \%$ of the publications chose elemental analysis, 40\% ICP after acid digestion and 14\% ion chromatography (IC) or titration after combusting the sample and absorbing resulting $\mathrm{SO} 2$ in an absorption solution. The most common analytical methods for analysing P, K, Na, Mg and Ca were ICPbased technologies after acid digestion of the solid samples $(63 \%$ to $83 \%$ of the publications). 


\subsubsection{Parameters related to energy conversion}

In the following sections collected data for the higher and lower heating value, the ash content, $\mathrm{Br}, \mathrm{F}$, and $\mathrm{Cl}$ are presented and discussed.

\section{Data Availability}

Among the parameters related to energy conversion most data were available for the ash content; 598 database entries were found, which were subsequently converted into 892 data points. The reviewed literature also presented a large amount of data for $\mathrm{Cl}(414$ database entries, 892 data points). We found 365 database entries for the higher heating value (HHV) (474 data points) and slightly fewer (i.e. 341 database entries) for the lower heating value (LHV). The least amount of information on energy content was found for inert and glass materials, and there was a particular paucity of information on $\mathrm{F}$ (133 database entries, 141 data points) and $\mathrm{Br}$ (41 database entries, 49 data points). For $\mathrm{F}$ concentrations in the waste material fractions inert, glass, composites and food waste, fewer than 10 data points were available, and in mixed organics fewer than five data points, making a statistical evaluation difficult. For $\mathrm{Br}$ concentrations, we found more than 10 data points only for mixed waste and combustibles, and more than five data points only for mixed organics, whereas for all other waste material fractions the data found was little or insufficient to provide a reliable dataset.

\section{Median concentrations and data ranges}

The highest median ash contents were found for glass (99\%TS), inert (97\%TS) and metal (97\%TS), while the lowest median occurred for plastic waste (10\%TS) (see Table 4). The highest median value for HHV and LHV was found in plastic $(33.5 \mathrm{MJ} / \mathrm{kgTS}$ and 30.5 $\mathrm{MJ} / \mathrm{kgTS}$, respectively) and the lowest in metal and glass (0.0 $0.4 \mathrm{MJ} / \mathrm{kgTS})$. Two out of six values for the HHV in glass, and one out of five in the inert material fraction, were reported below the detection limit. Variations among the data for $\mathrm{Cl}$ were generally high. The highest median $\mathrm{Cl}$ concentration was found for plastic (1.3\%TS) and the lowest was found in glass $(0.000 \% \mathrm{TS})$. The highest median $\mathrm{F}$ content was found in mixed waste $(0.05 \% \mathrm{TS})$ and the lowest in metals and glass $(0.000 \% \mathrm{TS})$. The quantiles for $\mathrm{F}$ in glass, composites and food waste were uncertain, as fewer than 10 data points were available. As 12 out of 16 data points for $\mathrm{F}$ in gardening waste were reported below the detection limit, the resulting quantiles are very unreliable and only one data point was found for $F$ in orga nic waste. The median $\mathrm{Br}$ content was highest in mixed waste $(0.016 \% \mathrm{TS})$, and the lowest median $\mathrm{Br}$ concentration of $0.001 \%$ TS was found in food waste, paper and cardboard, metal, glass and inert. For all waste material fractions except mixed waste, half or more of the available data were below the detection limit.

\section{Outliers, exceptional observations and limitations of the calculated value ranges}

WRAP (2010) reported VS contents for food waste from 25 towns and contributed with 120 to overall 196 data points $(61 \%)$ in the dataset for the ash content in food waste. While the data were labelled "volatile solids" and we calculated values for the associated ash content. However, the resulting ash contents appeared significantly higher than the corresponding values found in all the other publications and ash contents of $70-90 \%$ TS in 25 independent food waste samples is extremely unlikely. On this basis, we concluded that the presented values (WRAP, 2010) labelled as volatile solids must actually represent the reciprocal ash content values and we decided to include the data under this assumption. Generally, the ash content data showed large variations, especially for mixed and gardening waste. The highest ash contents for gardening waste were reported for sieved fine fractions, possibly due to high contents of soil and dust, while the lowest reported ash content in gardening waste originated from secondary data, for which the original source 
could not be accessed. In combustibles, the highest values were reported for vacuum cleaner bags and carpets. Interestingly, the ash contents reported for individual polymers were much lower than for mixed plastic scraps or other undefined plastic samples, possibly due to cross-contaminations, which may be removed more efficiently when checking every single plastic item for information on polymer types. The data for $\mathrm{Cl}$ in plastic waste varied significantly, showing clear differences between polymer types. The highest median $\mathrm{Cl}$ content of $47.2 \%$ TS occurred as expected in PVC, the median in HDPE was $18 \%$ TS and for the other polymer types the median $\mathrm{Cl}$ concentrations accounted for only $0.1 \% \mathrm{TS}$. Consequently, the abundance of PVC and HDPE in mixed plastic streams could be important when $\mathrm{Cl}$ contents are of concern. Very high concentrations of $\mathrm{Cl}$ and $\mathrm{Br}$ in the combustible material fraction were reported for the leather and rubber samples. The highest heating values reported for metals originated from ADEME (2007) and were 10 times higher than the second highest values. Although no publications addressed the analysis of metal samples separately, it is unlikely that the reported values (except ADEME, 2007) were obtained from oxygen-bomb-calorimetric measurements, because metals show considerable heat development in an oxygen atmosphere, as reported by Grosse and Conway (1958). Heating values for vacuum cleaner bags were among the lowest in the material fraction combustibles, which is in agreement with the very high ash content in these samples. The highest heating values in the combustible material fraction were reported for rubber samples. Considerable differences in energy contents of individual polymers in the plastic material fraction were observed: The lowest median HHVs were found in PVC (22.5 MJ/kgTS), PET (23.8 MJ/kgTS) and PU (26.1 MJ/kgTS), while the other polymers presented higher median HHV ranging from 38 to $45 \mathrm{MJ} / \mathrm{kgTS}$. Also, in the food waste fraction, considerable differences were observed between animal-derived food waste $(25.3 \mathrm{MJ} / \mathrm{kgTS})$ and vegetable food waste (15.3 MJ/kgTS).

\section{Characterisation and analytical methods}

In approximately $33 \%$ of the publications, and for approximately $55 \%$ of the data points, heating values were determined experimentally using an oxygen-bomb calorimeter; only one publication used waste product analysis of an incineration plant. Approximately half of the publications did not report from where the presented heating values originated (corresponding to about $20 \%$ of the data points). The remaining data originated from inaccessible primary sources. Also, for ash content, $52 \%$ of the publications ( $21 \%$ of data points) did not report any method or primary source. In $33 \%$ of the publications, and for $57 \%$ of the data points, experimental approaches were used for ash content determination. No ash content data were obtained via waste product analysis. Within the data from the experimental determination of ash content, various treatment temperatures were used. The majority of publications and data points used a temperature of $550^{\circ} \mathrm{C}$, which is recommended by several standard methods (e.g. CEN 14775, CEN 15403 and US EPA method 1684) for waste-derived fuels and biomass. One publication and $28 \%$ of the data were obtained using $900^{\circ} \mathrm{C}$. High temperatures between $815^{\circ} \mathrm{C}$ and $950^{\circ} \mathrm{C}$ were prescribed by standardised methods for coal analysis (e.g. ISO 1171, ASTM D3175) but as biomass and waste have a higher content of inorganic but volatile salts, which evaporate at such high temperatures, methods designated to coal analysis overestimate the VS content of waste (CEN, 2009). For $\mathrm{Cl}$, a considerably high share of the publications (i.e. 52\%) did not report how the presented $\mathrm{Cl}$ concentrations were determined, while $26 \%$ of the publications ( $43 \%$ of the data points) reported having used chemical analysis. For $\mathrm{F}$ and $\mathrm{Br}$, the shares of data originating from chemical analysis were $70 \%$ and $84 \%$, respectively. Only $10 \%$ of the publications presenting data for $\mathrm{Cl}$ ( $3 \%$ of data) used waste product analysis. For $\mathrm{F}$ and $\mathrm{Br}$, $10 \%$ and $11 \%$ of the data were obtained via waste product analysis. The dominant 
experimental method for $\mathrm{Cl}$ determination, used by $63 \%$ of the publications (i.e. $55 \%$ of the experimental data), was combustion either in a bomb calorimeter or via Schoniger combustion, followed by absorption of the combustion gases into a liquid and then ion content measurement via IC. In addition, ICP technologies after sample digestion were employed by $25 \%$ of the publications, thus corresponding to $27 \%$ of the data. For the chemical analysis of $\mathrm{F}$ and $\mathrm{Br}$ content, ICP technologies dominated.

\subsubsection{High-tech application elements}

In the following sections collected data for the elements $\mathrm{Ag}, \mathrm{Au}, \mathrm{B}, \mathrm{Bi}, \mathrm{Ga}, \mathrm{Gd}, \mathrm{Ge}, \mathrm{Hf}$, In, $\mathrm{Li}, \mathrm{Nb}, \mathrm{Nd}, \mathrm{Pr}, \mathrm{Pt}, \mathrm{Rb}, \mathrm{Rh}, \mathrm{Ru}, \mathrm{Sc}, \mathrm{Sn}, \mathrm{Sr}, \mathrm{Ta}, \mathrm{Te}, \mathrm{Ti}, \mathrm{W}, \mathrm{Y}$, and $\mathrm{Zr}$ are presented and discussed.

\section{Data Availability}

The data availability for these elements was generally lower than for the other element groups previously discussed. While WEEE and hazardous waste fractions were not addressed in this study, data availability for these waste fractions should be somewhat better as these elements are typically more abundant in electronic products. Furthermore, data were mostly found in recent publications, demonstrating an increased interest in recent years, e.g. related to discussions on criticality and strategic supply risks (Buchert et al., 2009; European Commission, 2010; US DOE, 2010). Most data in this group of elements were found for Sn (96 entries, 120 data points). For several material fractions little data was available; for plastics and inert waste fewer than 10 data points, and for glass, composites and food waste fewer than five data points were found. Additionally, nine of the database entries had values below the detection limit, thereby increasing uncertainty of these values, especially for material fractions such as metal, paper and plastic. For Ti, $\mathrm{Ag}, \mathrm{B}$ and $\mathrm{Sr}$, no data were found for composites, while very few data points were found for all other waste material fractions. For $\mathrm{Ti}$, fewer than 10 data points were available for organic waste and fewer than five for paper, plastic, glass, inert and food waste. For Ag only 10 data points were found for combustibles and even fewer for all other material fractions. Additionally, half of the values in food waste and all values in plastic were below the detection limit. For concentrations of B in the fractions organic, plastic, metal, glass and inert waste, only one data point was available per material fraction; similarly, for Sr in all waste material fractions except mixed waste and gardening waste, only one or two data points were found. Concentrations of $\mathrm{W}$ were only found for gardening, food and mixed waste. For the elements $\mathrm{Nb}, \mathrm{Sc}, \mathrm{Y}$ and $\mathrm{Zr}$, only data for mixed waste and gardening waste were found, and nearly all values for $\mathrm{Nb}$ in gardening waste were below the detection limit. Very few data and mostly values below the detection limits were found for $\mathrm{Li}$ and $\mathrm{Au}$, and only one database entry was found for each of the elements $\mathrm{Bi}, \mathrm{Ga}, \mathrm{Gd}, \mathrm{Ge}, \mathrm{Hf}$, In, Nd, Pr, $\mathrm{Pt}, \mathrm{Rb}, \mathrm{Rh}, \mathrm{Ru}, \mathrm{Ta}$ and Te.

\section{Median concentrations and data ranges}

Overall, the quantiles calculated for the elements in this group should be considered highly uncertain due to limited data with many values below the detection limit. For many waste material fractions medians could not be calculated. Comparison across individual fractions was possible only for the following elements (see all results in Appendix B): For $\mathrm{Sn}$, the highest median was found in metal $(1620 \mathrm{mg} / \mathrm{kgTS})$, though the data varied significantly and a considerable difference between ferrous $(1700 \mathrm{mg} / \mathrm{kgTS})$ and nonferrous metals (499 mg/kgTS) was found. The lowest median Sn concentration was found in paper and cardboard ( $1.4 \mathrm{mg} / \mathrm{kgTS})$. For $\mathrm{Ti}$, the highest median concentration was found in plastic $(4200 \mathrm{mg} / \mathrm{kgTS})$, possibly originating from titanium dioxide pigments, and the lowest in paper and cardboard (13 mg/kgTS). Within the combustible waste material 
fraction, Ti concentrations were higher in leather, rubber and carpets than in wood and textiles.

\section{Outliers, exceptional observations and limitations of the calculated value ranges}

Morf et al. (2013) offered the only source of data for Bi, Ga, Gd, Ge, Hf, In, Nd, Pr, Pt, $\mathrm{Rb}, \mathrm{Rh}, \mathrm{Ru}, \mathrm{Ta}$ and Te based on waste product analysis; however providing data only for the mixed waste input to an incinerator also receiving shares of industrial waste. Boldrin and Christensen (2010) provided the only source for $\mathrm{Nb}, \mathrm{Sc}, \mathrm{Y}$ and $\mathrm{Zr}$ in gardening waste, while $\mathrm{Li}$ and Au contents were investigated only by Morf et al. (2013), Eisted and Christensen (2011) and Belevi and Moench (2000).

\section{Characterisation and analytical methods}

As discussed previously for many elements in this category, only data from waste product analysis were available. However, for $\mathrm{Ag}, \mathrm{Au}, \mathrm{B}, \mathrm{Li}, \mathrm{Nb}, \mathrm{Sc}, \mathrm{Sn}, \mathrm{Sr}, \mathrm{Ti}, \mathrm{W}, \mathrm{Y}$ and $\mathrm{Zr}$, data from direct chemical analysis were also found. The share of experimental data varied between $50 \%$ and $80 \%$, depending on the individual elements. When direct chemical analysis was used, mostly ICP technologies were employed, while for the determination of Sn content, AAS ( $14 \%$ of data points) and XRF ( $23 \%$ of data points) were also used.

\subsection{Data gaps and implications for environmental assessment}

Significant amounts of physico-chemical data were published in non-ISI publications, e.g. grey literature, reports and theses. While publication of data in grey literature or local languages may be understandable, this may also limit accessibility to the data and limit the possibility to put new data sets into context. The dataset discussed in the previous sections, however, offers a systematic collection of waste composition data. The data sets provided in the appendixes may serve as a basis for identifying relevant data for individual waste material fractions to be used as input data in environmental assessment modelling, e.g. in relation to quantifying the environmental impacts by increasing source-segregation of recyclables or mixed waste to incineration.

Only few waste characterisation data were found for emerging economies and developing countries. Thanks to some Chinese publications, Asia was relatively well represented; however, composition data from other Asian countries, especially tropical countries, were very scarce, and almost no data were found for regions such as the MiddleEast and South America. As consumer behaviour and legislation in those countries may differ considerably from industrialised countries, the waste composition is likely to be significantly different as well. Applying waste composition data e.g. from Europe in life cycle assessment modelling of waste systems in other regions may potentially lead to wrong results and erroneous decisions. As such, further chemical characteristics of waste from less industrialised regions or regions with significantly different lifestyles, incomes and demographics are needed.

Very little data for precious metals and rare earth elements were found in literature. In most developed waste management systems, WEEE fractions may be handled separately from mixed household waste, or may be present only in very small quantities. Therefore, chemical composition data for these elements in MSW fractions should be applied in modelling with caution. However, linking these - often very low - concentrations to points of dissipation could provide valuable inputs for development of strategies for more resource-efficient systems by minimising such dissipation. Moreover, concentrations of some of these elements may become interesting in relation to research into nanoparticles and their dissipation in the environment (e.g. Ce and $\mathrm{Ag}$ ). As such, further research related to waste characterisation data for elements such as precious metals and rare earth 
elements in mixed waste flows may be needed to support more detailed environmental assessment studies including these elements.

\section{Conclusions}

Data for the physico-chemical composition of individual waste material fractions were extracted from existing literature, organised to allow comparison and then statistically evaluated. In total, 97 publications were assessed, providing 11,886 individual database entries. Detailed data for median concentrations and quantiles for 47 parameters (e.g. metals, nutrients, energy and ash content, halogens, rare earth elements) were provided for 11 individual waste material fractions. The literature overview showed that many chemical waste characterisation data are available from China, Europe and North America, while few or no data are available for metals of strategic concern (e.g. rare earth elements). However, the amount of collected data was insufficient for a consistent in-depth analysis of the influence of the regional context on the physico-chemical properties of individual waste materials. A significant share of the data was found in publications with objectives different from waste characterisation itself. Critical shortcomings in data labelling and description of experimental methods (e.g. errors in units, naming conventions, missing information and imprecise description of procedures) were observed for the addressed literature. This clearly suggests that transparency and consistency in data reporting from waste characterisation studies can be improved. Both chemical and physical parameters showed significant variations between publications. For some parameters, these variations could be associated with specific sub-fractions or items (e.g. Fe, Al, Mn, Cu in ferrous vs. non-ferrous metals, $\mathrm{Cl}$ in PVC, $\mathrm{S}$ in rubber etc.). Application of waste characterisation data from literature in environmental modelling requires careful consideration of data levels, potential influence from experimental methods and focus of the literature source. The overview of data and sources provided here (including the attached detailed datasets) may serve as a platform for more informed data selection e.g. in life cycle modelling where waste composition input data may critically influence the assessment results, as well as to choose appropriate uncertainty ranges.

\section{Acknowledgements}

The work was supported by the Danish Strategic Research Council via the IRMAR grant (Integrated Resource Management \& Recovery, project No. 11-116775) and the 3R Research School. We thank Camilla Thyregod from DTU Compute for inputs regarding statistical evaluation of the literature data. 


\section{References}

Abu-Qudais, M., Abu-Qdais, H. a., 2000. Energy content of municipal solid waste in Jordan and its potential utilization. Energy Convers. Manag. 41, 983-991. doi:10.1016/S01968904(99)00155-7

ADEME (Agence de l'Environnement et de la Maîtrise de l'Énergie), 2007. La composition des ordures ménagères et assimilées en France (Compositions of household waste and similar watses in France). French environmnental protection and energy agency.

Andersen, J.K., Boldrin, A., Christensen, T.H., Scheutz, C., 2010. Mass balances and life-cycle inventory for a garden waste windrow composting plant (Aarhus, Denmark). Waste Manag. Res. 28, 1010-1020. doi:10.1177/0734242X10360216

Arena, U., Di Gregorio, F., 2014. A waste management planning based on substance flow analysis. Resour. Conserv. Recycl. 85, 54-66. doi:10.1016/j.resconrec.2013.05.008

Astrup, T.F., Tonini, D., Turconi, R., Boldrin, A., 2015. Life cycle assessment of thermal Waste-to-Energy technologies: Review and recommendations. Waste Manag. 37, 104115. doi:10.1016/j.wasman.2014.06.011

Astrup, T., Riber, C., Pedersen, a. J., 2011. Incinerator performance: effects of changes in waste input and furnace operation on air emissions and residues. Waste Manag. Res. 29, S57-S68. doi:10.1177/0734242X11419893

Auhorn, W.J., 2012. Paper and Board, 3. Chemical Additives, in: Ullmann's Encyclopedia of Industrial Chemistry. Wiley-VCH Verlag GmbH \& Co.KGaA, Weinheim. doi:10.1002/14356007.018_o11

Aye, L., Widjaya, E.R., 2006. Environmental and economic analyses of waste disposal options for traditional markets in Indonesia. Waste Manag. 26, 1180-91. doi:10.1016/j.wasman.2005.09.010

Bailie, R.C., Everett, J.W., Lipták, B.G., Liu, D.H.F., Rugg, F.M., Switzenbaum, M.S., 1997. Solid Waste, in: Liu, D.H.. F.., Lipták, B.G.. (Eds.), Environmental Engineer's Handbook. CRC Press.

Belevi, H., Moench, H., 2000. Factors Determining the Element Behavior in Municipal Solid Waste Inicinerators. 1. Field Studies. Environ. Sci. Technol. 34, 2501-2506.

Boldrin, A., Christensen, T.H., 2010. Seasonal generation and composition of garden waste in Aarhus (Denmark). Waste Manag. 30, 551-7. doi:10.1016/j.wasman.2009.11.031

Brunner, P.H., Ernst, W.R., 1986. Alternative Methods for the Analysis of Municipal Solid Waste. Waste Manag. Res. 4, 147-160.

Brunner, P.H., Rechberger, H., 2014. Waste to energy - key element for sustainable waste management. Waste Manag. 37, 3-12. doi:10.1016/j.wasman.2014.02.003

Buchert, M., Schüler, D., Bleher, D., 2009. Critical Metals for Future Sustainable Technologies and their Recycling Potential. United Nations Environment Programme (UNEP)

CEN (European Committee for Standardization), 2009. European Standard EN 14775: Solid biofuels - Determination of ash content.

Chandrappa, R., Das, D.B., 2012. Solid Waste Management, in: Environmnetal Science and Engineering, Environmental Science and Engineering. Springer Berlin Heidelberg, Berlin, Heidelberg, pp. 47-63. doi:10.1007/978-3-642-28681-0

Cherubini, F., Bargigli, S., Ulgiati, S., 2008. Life cycle assessment of urban waste management: energy performances and environmental impacts. The case of Rome, Italy. Waste Manag. 28, 2552-64. doi:10.1016/j.wasman.2007.11.011

Clavreul, J., Baumeister, H., Christensen, T.H., Damgaard, A., 2014. An environmental assessment system for environmental technologies. Environ. Model. Softw. 60, 18-30. doi:10.1016/j.envsoft.2014.06.007 
Clavreul, J., Guyonnet, D., Christensen, T.H., 2012. Quantifying uncertainty in LCAmodelling of waste management systems. Waste Manag. 32, 2482-95. doi:10.1016/j.wasman.2012.07.008

Dahlén, L., Lagerkvist, A., 2008. Methods for household waste composition studies. Waste Manag. 28, 1100-12. doi:10.1016/j.wasman.2007.08.014

Das, A., Vasanthi, R., Goel, M., Kumar, K.R., 2013. Auditing Waste Management Practices in an Indian City. Res. J. Pharm. , Biol. Chem. Sci. 4, 1026-1032.

Eisted, R., Christensen, T.H., 2011. Characterization of householdwaste in Greenland. Waste Manag. 31, 1461-6. doi:10.1016/j.wasman.2011.02.018

European Commission, 2010. Critical raw materials for the EU, Report of the ad-hoc working group on defining critical raw materials. doi:10.1002/eji.200839120.IL-17Producing

Ferrari, G., Gregorio, P., Sammito, R., 2000. La valutazione delle caratteristiche dei rifiuti per una gestione dei rifiuti ambientalmente compatibile (Waste charcterization for environmentally sound waste managemenet), in: $39^{\circ}$ Congr. Naz. SItl "La Promozione Della Salute Nel Terzo Millennio", September 24-27 2000. Ferrara (Italy), pp. 278-281.

Fruergaard, T., Astrup, T., 2011. Optimal utilization of waste-to-energy in an LCA perspective. Waste Manag. 31, 572-82. doi:10.1016/j.wasman.2010.09.009

Gidarakos, E., Havas, G., Ntzamilis, P., 2006. Municipal solid waste composition determination supporting the integrated solid waste management system in the island of Crete. Waste Manag. 26, 668-79. doi:10.1016/j.wasman.2005.07.018

Granados, C., Rojas, N., Giraldo, L., Moreno, J.C., 2004. Preliminary Exploration of the Behavior of Conduction Calorimetric Cells in the Determination of the Caloric Value of Municipal Solid Waste. Instrum. Sci. Technol. 32, 139-152. doi:10.1081/Cl-120028767

Grosse, A. V., Conway, J.B., 1958. Combustion of metals in oxygen. Ind. Eng. Chem. 50, 663672. doi:10.1021/ie50580a040

Gy, P., 1998. Sampling for Analytical Purposes. John Wiley \& Sons Ltd.

Hanc, A., Novak, P., Dvorak, M., Habart, J., Svehla, P., 2011. Composition and parameters of household bio-waste in four seasons. Waste Manag. 31, 1450-60. doi:10.1016/j.wasman.2011.02.016

He, M., Xiao, B., Hu, Z., Liu, S., Guo, X., Luo, S., 2009. Syngas production from catalytic gasification of waste polyethylene: Influence of temperature on gas yield and composition. Int. J. Hydrogen Energy 34, 1342-1348. doi:10.1016/j.ijhydene.2008.12.023

Korzun, E. a, Heck, H.H., 1990. Sources and fates of lead and cadmium in municipal solid waste. J. Air Waste Manage. Assoc. 40, 1220-1226. doi:10.1080/10473289.1990.10466766

Kost, T., 2001. Brennstofftechnische Characterisierung von Haushaltsabfällen (Fuel characteristics of household waste), PhD Thesis. Technische Universität Dresden (Germany).

La Cour Jansen, J., Spliid, H., Hansen, T.L., Svärd, A., Christensen, T.H., 2004. Assessment of sampling and chemical analysis of source-separated organic household waste. Waste Manag. 24, 541-9. doi:10.1016/j.wasman.2004.02.013

Laurent, A., Clavreul, J., Bernstad, A., Bakas, I., Niero, M., Gentil, E., Christensen, T.H., Hauschild, M.Z., 2014. Review of LCA studies of solid waste management systems - Part II: Methodological guidance for a better practice. Waste Manag. 34, 589-606. doi:10.1016/j.wasman.2013.12.004

LfU (Bayrisches Landesamt für Umweltschutz), 2003. Zusammensetzung und Schadstoffgehalt von Siedlungsabfällen (Composition and contaminants content of municipal solid waste). Bavarian authority for environmental protection (Germany). 
LfU (Bayrisches Landesamt für Umweltschutz), 2002. Restmüllanalysen - eine Grundlage eines nachhaltigen Stoffstrommanagements der Abfallwirtschaft (Residual waste characterization - foundation of sustainable material flow management in the waste management sector). Bavarian authority for environmental protection (Germany).

Liu, Y., Liu, Y., 2005. Novel Incineration Technology Integrated with Drying, Pyrolysis, Gasification, and Combustion of MSW and Ashes Vitrification. Environmnetal Sci. Technol. 39, 3855-3863.

Ma, W., Hoffmann, G., Schirmer, M., Chen, G., Rotter, V.S., 2010. Chlorine characte rization and thermal behavior in MSW and RDF. J. Hazard. Mater. 178, 489-98. doi:10.1016/j.jhazmat.2010.01.108

Manfredi, S., Tonini, D., Christensen, T.H., 2011. Environmental assessment of different management options for individual waste fractions by means of life-cycle assessment modelling. Resour. Conserv. Recycl. 55, 995-1004. doi:10.1016/j.resconrec.2011.05.009

Manfredi, S., Tonini, D., Christensen, T.H., 2010. Contribution of individual waste fractions to the environmental impacts from landfilling of municipal solid waste. Waste Manag. 30, 433-440. doi:10.1016/j.wasman.2009.09.017

Maystre, L.Y., Viret, F., 1995. A Goal-Oriented Characterization of Urban Waste. Waste Manag. Res. 13, 207-218. doi:10.1177/0734242X9501300303

Morf, L., 2006. Chemische Zusammensetzung verbrannter Siedlungsabfälle Untersuchungen im Einzugsgebiet der KVA Thurgau, in: Umweltwissen Nr. 0620 Bundesamt Für Umwelt. Bundesamt für Umwelt BAFU, Bern, pp. 1-104.

Morf, L.S., Brunner, P.H., Spaun, S., 2000. Effect of operating conditions and input variations on the partitioning of metals in a municipal solid waste incinerator. Waste Manag. Res. 18, 4-15. doi:10.1177/0734242X0001800102

Morf, L.S., Brunner, P.H., 1998. The MSW Incinerator as a Monitoring Tool for Waste Management 32, 1825-1831.

Morf, L.S., Gloor, R., Haag, O., Haupt, M., Skutan, S., Di Lorenzo, F., Böni, D., 2013. Precious metals and rare earth elements in municipal solid waste--sources and fate in a Swiss incineration plant. Waste Manag. 33, 634-44. doi:10.1016/j.wasman.2012.09.010

Olajire, A.A., Ayodele, E.T., 1998. Heavy metals analysis of solid municipal wastes in the western part of nigeria. Water. Air. Soil Pollut. 219-228.

Petersen, L., Dahl, C.K., Esbensen, K.H., 2004. Representative mass reduction in sampling a critical survey of techniques and hardware. Chemom. Intell. Lab. Syst. 74, 95-114. doi:10.1016/j.chemolab.2004.03.020

Pivnenko, K., Eriksson, E., Astrup, T.F., 2015. Waste paper for recycling: Overview and identification of potentially critical substances. Waste Manag. doi:10.1016/j.wasman.2015.02.028

Riber, C., 2005. Heavy metal content of combustible municipal solid waste in Denmark. Waste Manag. Res. 23, 126-132. doi:10.1177/0734242X05051195

Riber, C., Rodushkin, I., Spliid, H., Christensen, T.H., 2007. Method for fractional solid-waste sampling and chemical analysis. Int. J. Environ. Anal. Chem. 87, 321-335. doi:10.1080/03067310701189067

Riber, C., Petersen, C., Christensen, T.H., 2009. Chemical composition of material fractions in Danish household waste. Waste Manag. 29, 1251-7. doi:10.1016/j.wasman.2008.09.013

RIVM (Rijksinstituut voor volksgezondheid en milieu), 1999. Chemische analyse van huishoudelijk restafval-Resultaten 1994 en 1995 (Chemical analysis of household residual waste- results 1994 and 1994). Dutch national institute of public health and the environment. 
Rotter, V.S., 2002. Schwermetalle in Haushaltsabfällen (Heavy metals in household waste), PhD Thesis. Technische Universität Dresden (Germany).

Rotter, V.S., Kost, T., Winkler, J., Bilitewski, B., 2004. Material flow analysis of RDFproduction processes. Waste Manag. 24, 1005-21. doi:10.1016/j.wasman.2004.07.015

SAEFL (Swiss Agency for the Environmnet, Forests and Landscape), 2004. A survey of the composition of household waste 2001/02. Environ. Ser. No. 356.

Slagstad, H., Bratteb $\varnothing, H_{.}, 2013$. Influence of assumptions about household waste composition in waste management LCAs. Waste Manag. 33, 212-9. doi:10.1016/j.wasman.2012.09.020

Tchobanoglous, G., Theisen, H., Vigil, S., 1993. Integrated Solid Waste Management. McGraw-Hill, Inc.

Topanou, N., 2011. Characterization of Household Solid Waste in the Town of Abomey Calavi in Benin. J. Environ. Prot. (Irvine,. Calif). 02, 692-699. doi:10.4236/jep.2011.26080

US DOE (US Department of Energy), 2010. Critical Materiasl Strategy, December 2010 1166. doi:10.2172/1000846

WRAP, 2010. Food waste Chemical Analysis- Final Report.

Xiao, G., Ni, M., Chi, Y., Jin, B., Xiao, R., Zhong, Z., Huang, Y., 2009. Gasification characteristics of MSW and an ANN prediction model. Waste Manag. 29, 240-4. doi:10.1016/j.wasman.2008.02.022

Zhang, H., He, P.-J., Shao, L.-M., 2008. Implication of heavy metals distribution for a municipal solid waste management system--a case study in Shanghai. Sci. Total Environ. 402, 257-67. doi:10.1016/j.scitotenv.2008.04.047

Zhang, R., El-Mashad, H., Hartman, K., Wang, F., Rapport, J., Choate, C., Gamble, P., 2005. Anaerobic phased solids digester pilot demonstration project: Characterization of food and green wastes as a feedstock for anaerobic digesters, California Energy Commission.

Zhou, H., Meng, A., Long, Y., Li, Q., Zhang, Y., 2014. An overview of characteristics of municipal solid waste fuel in China: Physical, chemical composition and heating value. Renew. Sustain. Energy Rev. 36, 107-122. doi:10.1016/j.rser.2014.04.024

Øygard, J.K., Måge, A., Gjengedal, E., 2004. Estimation of the mass-balance of selected metals in four sanitary landfills in Western Norway, with emphasis on the heavy metal content of the deposited waste and the leachate. Water Res. 38, 2851-8. doi:10.1016/j.watres.2004.03.036 


\title{
Appendix A
}

for

\section{Physico-chemical characterisation of material fractions in household waste: overview of data in literature}

\author{
Ramona Götze*, Alessio Boldrin, Charlotte Scheutz, Thomas Fruergaard Astrup \\ Department of Environmental Engineering, Technical University of Denmark, Building 113, 2800 Kgs. Lyngby, \\ Denmark \\ *Corresponding author’s e-mail: rmog@env.dtu.dk
}

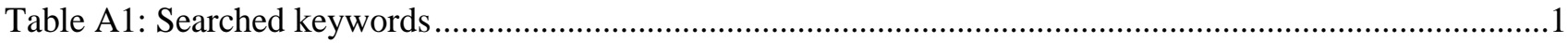

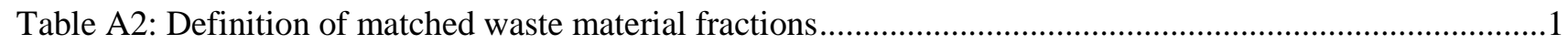

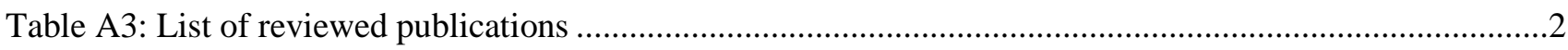

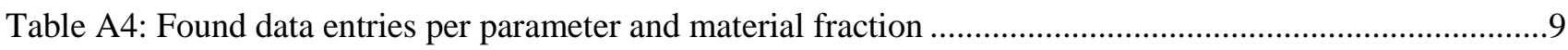

Table A5: Frequency of waste characterization approaches employed for the individual parameters and for the respective element group expressed as $\%$ of data points ..............................................................................10

Table A5 (continued): Frequency of waste characterization approaches employed for the individual parameters and for the respective element group expressed as $\%$ of data points ............................................11

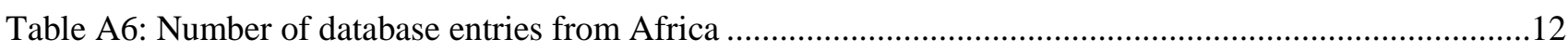

Table A7: Number of database entries from America-north ......................................................................13

Table A8: Number of database entries from America-south.........................................................................14

Table A9: Number of database entries from Asia ....................................................................................15

Table A10: Number of database entries from Europe ...................................................................................16

Table A11: Number of database entries from Middle East .......................................................................17

Table A12: Number of database entries from secondary data reporting .......................................................18

Table A13: Number of database entries from unknown regional origin ....................................................19 


\section{Table A1: Searched keywords}

municipal solid waste, waste characterization, waste composition, waste analysis, waste management, heavy metals, nutrients, energy content or a combination of those terms, as well as translated equivalents in French, Italian, German, and Dutch.

\section{Table A2: Definition of matched waste material fractions}

\section{Waste material fraction}

Mixed organics

Food waste

Gardening waste

Paper \& Cardboard

Composites

Plastic

Combustibles

Metal

Glass

Inert

Mix

\section{Included material fractions as reported}

Sampled fractions called e.g. organic, bio waste, or kitchen waste, which are not further specified and likely contain a mixture of food waste and waste from gardening activities.

Waste samples clearly labelled as food waste or organic fractions sampled from restaurants, canteens, butchers, etc.

Organic waste from private or public gardening activities, e.g. yard trimmings, branches or fractions called green waste with specific description.

Fractions containing different paper and cardboard products, e.g. cardboard packaging, newspapers, napkins. If very general paper and cardboard fractions were reported laminated paper which we consider as composite material may have been included in this fraction.

Laminated paper, e.g. juice cartons, laminated plastics e.g. aluminum-coated plastic foil, other sampled fractions called composites

Plastic fractions containing different plastic products and polymer types, e.g. plastic packaging and household items. The polymer composition strongly depends on the waste sampling campaign and recycling/ take-back systems in place.

All samples labelled as combustible, wood, sanitary products (e.g. diapers), textiles, rubber, leather, and cigarette butts.

All samples called metal and more detailedly sorted metal items e.g. aluminium foil, beverage cans, etc.

Fractions containing glass from different glass products, e.g. glass packaging

Fractions called non-combustibles or inert, or more detailed fractions such as construction and demolition waste from residual household waste, stones, soil, and ceramics.

Values reported for residual MSW or HHW, sieved fine fractions from MSW and HHW waste sorting campaigns. 


\section{Table A3: List of reviewed publications}

Abanades, S., Flamant, G., Gagnepain, B., Gauthier, D., 2002. Fate of heavy metals during municipal solid waste incineration. Waste Manag. Res. 20, 55-68. doi:10.1177/0734242X0202000107

Abu-Qudais, M., Abu-Qdais, H. a., 2000. Energy content of municipal solid waste in Jordan and its potential utilization. Energy Convers. Manag. 41, 983-991. doi:10.1016/S0196-8904(99)00155-7

ADEME (Agence de l'Environnement et de la Maîtrise de l'Énergie), 2009. Campagne national de caractérisation des ordures ménagères - Résultats Année 2007 (National characterization campaign of household waste - Results from the year 2007). French environmnental protection and energy agency.

ADEME (Agence de l'Environnement et de la Maîtrise de l'Énergie), 2007. La composition des ordures ménagères et assimilées en France (Compositions of household waste and similar watses in France). French environmnental protection and energy agency.

Adhikari, B.K., Barrington, S., Martinez, J., King, S., 2008. Characterization of food waste and bulking agents for composting. Waste Manag. 28, 795-804. doi:10.1016/j.wasman.2007.08.018

Akinci, G., Guven, E.D., Gok, G., 2012. Evaluation of waste management options and resource conservation potentials according to the waste characteristics and household income: A case study in Aegean Region, Turkey. Resour. Conserv. Recycl. 58, 114-124. doi:10.1016/j.resconrec.2011.11.005

Andersen, J.K., Boldrin, A., Christensen, T.H., Scheutz, C., 2011. Mass balances and life cycle inventory of home composting of organic waste. Waste Manag. 31, 1934-42. doi:10.1016/j.wasman.2011.05.004

Arena, U., Chirone, R., Di Gregorio, F., Solimene, R., Urciuola, M., Zaccariello, L., 2012. A Comparison between fluidized bed combustion and gasification of a mixed plastic waste, in: 21rst International Conference on Fluidized Bed Combustion, June 3-6 2012. Neaples, pp. 752-759.

Arena, U., Di Gregorio, F., Amorese, C., Mastellone, M.L., 2011. A techno-economic comparison of fluidized bed gasification of two mixed plastic wastes. Waste Manag. 31, 1494-1504.

doi:10.1016/j.wasman.2011.02.004

Arena, U., Mastellone, M.L., 2009. Gassificazione a letto fluido di CDR e imballaggi post-consumo (Fluidized bed gasification of RDF and post-consumer packaging). AMRA; Facolta di Scienze Ambientali, Seconda Universta di Napoli (Italy).

Astrup, T., Riber, C., Pedersen, a. J., 2011. Incinerator performance: effects of changes in waste input and furnace operation on air emissions and residues. Waste Manag. Res. 29, S57-S68.

doi:10.1177/0734242X11419893

Bailie, R.C., Everett, J.W., Lipták, B.G., Liu, D.H.F., Rugg, F.M., Switzenbaum, M.S., 1997. Solid Waste, in: Liu, D.H.. F.., Lipták, B.G.. (Eds.), Environmental Engineer’s Handbook. CRC Press.

Belevi, H., Moench, H., 2000. Factors Determining the Element Behavior in Municipal Solid Waste Inicinerators. 1. Field Studies. Environ. Sci. Technol. 34, 2501-2506. 
Boldrin, A., Christensen, T.H., 2010. Seasonal generation and composition of garden waste in Aarhus (Denmark). Waste Manag. 30, 551-7. doi:10.1016/j.wasman.2009.11.031

Burnley, S.J., 2007. The use of chemical composition data in waste management planning--a case study. Waste Manag. 27, 327-36. doi:10.1016/j.wasman.2005.12.020

Büll, U., Zwisele, B., Nogueira, M., Niestroj, J., 2009. Erhebung repräsentativer Planungs daten für die Restabfallbehandlung eines Entsorgungsgebietes (Acertainment of planning data for the residual waste treatment in a disposal area). Müll und Abfall 1/05, 6-16.

Chandrappa, R., Das, D.B., 2012. Solid Waste Management, in: Environmnetal Science and Engineering, Environmental Science and Engineering. Springer Berlin Heidelberg, Berlin, Heidelberg, pp. 47-63. doi:10.1007/978-3-642-28681-0

Chang, N.-B., Davila, E., 2008. Municipal solid waste characterization and management strategies for the lower rio grande valley, Texas. Waste Manag. 28, 776-94. doi:10.1016/j.wasman.2007.04.002

Chang, Y., Chang, N., Chen, W.C., 1998. Systematic Evaluation and Uncertainty Analysis of the RefuseDerived Fuel Process in Taiwan Systematic Evaluation and Uncertainty Analysis of the Refuse-Derived Fuel Process in Taiwan. J. Air Waste Manage. Assoc. 48, 537-544.

Chang, Y.-H., Chen, W.C., Chang, N.-B., 1998. Comparative evaluation of RDF and MSW incineration. J. Hazard. Mater. 58, 33-45. doi:10.1016/S0304-3894(97)00118-0

Choi, K.I., Lee, S.H., Lee, D.H., Osako, M., 2008. Fundamental characteristics of input waste of small MSW incinerators in Korea. Waste Manag. 28, 2293-2300. doi:10.1016/j.wasman.2007.10.008

Das, A., Vasanthi, R., Goel, M., Kumar, K.R., 2013. Auditing Waste Management Practices in an Indian City. Res. J. Pharm. , Biol. Chem. Sci. 4, 1026-1032.

De Medina-Salas, L., Castillo González, E., Romero-López, R., 2013. Physical and Chemical Characteristics of Municipal Solid Waste in a Rural Locality- Study Case : Cosautlán De Carvajal, Veracruz, Mexico. Int. J. Business, Humanit. Technol. 3, 117-122.

Del Tedesco, S., 2009. Incenerimento dei rifiuti solidi urbani con recupero energetico (Incineration of municipal solid waste with energy recovery) - BSc Thesis. Università degli studi di Padova (Italy).

Desroches-Ducarne, E., Martya, E., Martin, G., Delfosse, L., 1998. Co-combustion of coal and municipal solid waste in a circulating fluidized bed. Fuel 77, 1311-1315.

Dong, C., Jin, B., Zhong, Z., Lan, J., 2002. Tests on co-firing of municipal solid waste and coal in a circulating fluidized bed. Energy Convers. Manag. 43, 2189-2199. doi:10.1016/S0196-8904(01)00157-1

Durlak, S.K., Biswas, P., Shi, J., 1997. Equilibrium analysis of the affect of temperature, moisture and sodium content on heavy metal emissions from municipal solid waste incinerators. J. Hazard. Mater. 56, 1-20.

Eisted, R., Christensen, T.H., 2011. Characterization of householdwaste in Greenland. Waste Manag. 31, 14616. doi:10.1016/j.wasman.2011.02.018 
Ferrari, G., Gregorio, P., Sammito, R., 2000. La valutazione delle caratteristiche dei rifiuti per una gestione dei rifiuti ambientalmente compatibile (Waste charcterization for environmentally sound waste managemenet), in: 39 Congr. Naz. SItI “La Promozione Della Salute Nel Terzo Millennio”, September 24-27 2000. Ferrara (Italy), pp. 278-281.

Fialho, L.L., Lopes da Silva, W.T., Milori, D.M.B.P., Simões, M.L., Martin-Neto, L., 2010. Characterization of organic matter from composting of different residues by physicochemical and spectroscopic methods. Bioresour. Technol. 101, 1927-34. doi:10.1016/j.biortech.2009.10.039

Flyhammar, P., 1997. Estimation of heavy metal transformations in municipal solid waste. Sci. Total Environ. 198, 123-133. doi:10.1016/S0048-9697(97)05439-9

Francois, V., 2004. Détermination d'indicateurs d'acceleration et de stabilisation de déchets ménagers enfouis. Etude de l'impact de la recirculation de lixiviats sur colonnes de dechets (Determination of indicators of accelerated stabilisation of landfilled mixed waste), $\mathrm{PhD}$ Thesis. Universite de Limoges (France).

García, a. J., Esteban, M.B., Márquez, M.C., Ramos, P., 2005. Biodegradable municipal solid waste: Characterization and potential use as animal feedstuffs. Waste Manag. 25, 780-787. doi:10.1016/j.wasman.2005.01.006

Granados, C., Rojas, N., Giraldo, L., Moreno, J.C., 2004. Preliminary Exploration of the Behavior of Conduction Calorimetric Cells in the Determination of the Caloric Value of Municipal Solid Waste. Instrum. Sci. Technol. 32, 139-152. doi:10.1081/CI-120028767

Guo, X., Wang, Z., Li, H., Huang, H., Wu, C., Chen, Y., Li, B., 2001. A Study on Combustion Characteristics and Kinetic Model of Municipal Solid Wastes. Energy \& Fuels 15, 1441-1446. doi:10.1021/ef010068f

Hanc, A., Novak, P., Dvorak, M., Habart, J., Svehla, P., 2011. Composition and parameters of household biowaste in four seasons. Waste Manag. 31, 1450-60. doi:10.1016/j.wasman.2011.02.016

Hanc, A., Szakova, J., Ochecova, P., 2014. Differences in the mobility of Cd, $\mathrm{Cu}, \mathrm{Pb}$ and $\mathrm{Zn}$ during composting of two types of household bio-waste collected in four seasons. Bioresour. Technol. 168, 204-13. doi:10.1016/j.biortech.2014.01.125

Hansen, T.L., Jansen, J.L.C., Spliid, H., Davidsson, A., Christensen, T.H., 2007. Composition of source-sorted municipal organic waste collected in Danish cities. Waste Manag. 27, 510-8. doi:10.1016/j.wasman.2006.03.008

He, M., Xiao, B., Hu, Z., Liu, S., Guo, X., Luo, S., 2009. Syngas production from catalytic gasification of waste polyethylene: Influence of temperature on gas yield and composition. Int. J. Hydrogen Energy 34, 13421348. doi:10.1016/j.ijhydene.2008.12.023

Hellweg, S., 2000. Time- and Site-Dependent Life-Cycle Assessment of Waste treatment Processes, PhD Thesis. Swiss Federal Institute of Technology (ETH Zurich, Switzerland).

Ikeguchi, T., Karchanawong, S., Koottatep, S., 1994. Improvement of an empirical equation relating ash and carbon contents of municipal solid waste. Environ. Technol. 15, 395-399.

Jung, C.H., Matsuto, T., Tanaka, N., 2006. Flow analysis of metals in a municipal solid waste management system. Waste Manag. 26, 1337-48. doi:10.1016/j.wasman.2005.11.018 
Kathiravale, S., Yunus, M.N.M., Sopian, K., Samsuddin, A.H., Rahman, R.A., 2003. Modeling the heating value of Municipal Solid Waste. Fuel 82, 1119-1125. doi:10.1016/S0016-2361(03)00009-7

Kikuchi, R., Kukacka, J., Raschman, R., 2008. Grouping of mixed waste plastics according to chlorine content. Sep. Purif. Technol. 61, 75-81. doi:10.1016/j.seppur.2007.10.001

Komilis, D., Bandi, D., Kakaronis, G., Zouppouris, G., 2011. The influence of spent household batteries to the organic fraction of municipal solid wastes during composting. Sci. Total Environ. 409, 2555-2566. doi:10.1016/j.scitotenv.2011.02.044

Komilis, D., Evangelou, A., Giannakis, G., Lymperis, C., 2012. Revisiting the elemental composition and the calorific value of the organic fraction of municipal solid wastes. Waste Manag. 32, 372-81. doi:10.1016/j.wasman.2011.10.034

Korzun, E. a, Heck, H.H., 1990. Sources and fates of lead and cadmium in municipal solid waste. J. Air Waste Manage. Assoc. 40, 1220-1226. doi:10.1080/10473289.1990.10466766

Kost, T., 2001. Brennstofftechnische Characterisierung von Haushaltsabfällen (Fuel characteristics of household waste), PhD Thesis. Technische Universität Dresden (Germany).

La Cour Jansen, J., Spliid, H., Hansen, T.L., Svärd, A., Christensen, T.H., 2004. Assessment of sampling and chemical analysis of source-separated organic household waste. Waste Manag. 24, 541-9. doi:10.1016/j.wasman.2004.02.013

Lagerkvist, A., Ecke, H., Christensen, T.H., 2011. Waste Generation and Characterization Waste Characterization : Approaches and Methods, in: Christensen, T.H. (Ed.), Solid Waste Technology and Managament. Blackwell Publishing Ltd.

Lariviere, M., 2007. Methodology for Allocating Municipal Solid Waste to Biogenic and Non-Biogenic Energy. Energy Inf. Adm. Off. Coal 1-18.

LfU (Bayrisches Landesamt für Umweltschutz), 2003a. Kompostierung von Bioabfällen mit anderen organischen Abfällen (Co-cmposting of biowaste with other organic waste types). Bavarian authority for environmental protection (Germany).

LfU (Bayrisches Landesamt für Umweltschutz), 2003b. Zusammensetzung und Schadstoff- gehalt von Siedlungsabfällen (Composition and contaminants content of municipal solid waste). Bavarian authority for environmental protection (Germany).

LfU (Bayrisches Landesamt für Umweltschutz), 2002. Restmüllanalysen - eine Grundlage eines nachhaltigen Stoffstrommanagements der Abfallwirtschaft (Residual waste characterization - foundation of sustainable material flow management in the waste management sector) . Bavarian authority for environmental protection (Germany).

Liu, J., Paode, R., Holsen, T., 1996. Modeling the energy content of municipal solid waste using multiple regression analysis. J. Air Waste Manag. Assoc., 37-41.

Liu, Y., Liu, Y., 2005. Novel Incineration Technology Integrated with Drying, Pyrolysis, Gasification, and Combustion of MSW and Ashes Vitrification. Environmnetal Sci. Technol. 39, 3855-3863. 
Long, Y.-Y., Shen, D.-S., Wang, H.-T., Lu, W.-J., Zhao, Y., 2011. Heavy metal source analysis in municipal solid waste (MSW): case study on Cu and Zn. J. Hazard. Mater. 186, 1082-7.

doi:10.1016/j.jhazmat.2010.11.106

López, M., Soliva, M., Martínez-Farré, F.X., Fernández, M., Huerta-Pujol, O., 2010. Evaluation of MSW organic fraction for composting: Separate collection or mechanical sorting. Resour. Conserv. Recycl. 54, 222-228. doi:10.1016/j.resconrec.2009.08.003

Luo, S., Xiao, B., Hu, Z., Liu, S., 2010. Effect of particle size on pyrolysis of single-component municipal solid waste in fixed bed reactor. Int. J. Hydrogen Energy 35, 93-97. doi:10.1016/j.ijhydene.2009.10.048

Ma, W., Hoffmann, G., Schirmer, M., Chen, G., Rotter, V.S., 2010. Chlorine characterization and thermal behavior in MSW and RDF. J. Hazard. Mater. 178, 489-98. doi:10.1016/j.jhazmat.2010.01.108

Manu, M.K., Kumar, R., Garg, A., 2013. Physical and Chemical Characterization of Yard Waste. Int. J. Appl. Eng. Res. 8, 1891-1896.

Maystre, L.Y., Viret, F., 1995. A Goal-Oriented Characterization of Urban Waste. Waste Manag. Res. 13, 207218. doi:10.1177/0734242X9501300303

Menikpura, S.N.M., Basnayake, B.F. a., 2009. New applications of "Hess Law" and comparisons with models for determining calorific values of municipal solid wastes in the Sri Lankan context. Renew. Energy 34, 1587-1594. doi:10.1016/j.renene.2008.11.005

Morf, L., 2006. Chemische Zusammensetzung verbrannter Siedlungsabfälle - Untersuchungen im Einzugsgebiet der KVA Thurgau, in: Umweltwissen Nr. 0620 Bundesamt Für Umwelt. Bundesamt für Umwelt BAFU, Bern, pp. 1-104.

Morf, L.S., Brunner, P.H., Spaun, S., 2000. Effect of operating conditions and input variations on the partitioning of metals in a municipal solid waste incinerator. Waste Manag. Res. 18, 4-15. doi:10.1177/0734242X0001800102

Morf, L.S., Gloor, R., Haag, O., Haupt, M., Skutan, S., Di Lorenzo, F., Böni, D., 2013. Precious metals and rare earth elements in municipal solid waste--sources and fate in a Swiss incineration plant. Waste Manag. 33, 634-44. doi:10.1016/j.wasman.2012.09.010

Murphy, M.L., 2004. Waste-to-Energy Technology. Encycl. Energy, Vol. 6.

Olajire, A.A., Ayodele, E.T., 1998. Heavy metals analysis of solid municipal wastes in the western part of Nigeria. Water. Air. Soil Pollut. 219-228.

Patumsawad, S., 2002. Experimental study on fluidised bed combustion of high moisture municipal solid waste. Energy Convers. Manag. 43, 2329-2340. doi:10.1016/S0196-8904(01)00197-2

Philippe, F., Culot, M., 2009. Household solid waste generation and characteristics in Cape Haitian city, Republic of Haiti. Resour. Conserv. Recycl. 54, 73-78. doi:10.1016/j.resconrec.2009.06.009

Pitchel, J., 2005. Characterization of solid waste, in: Waste Management Practices: Municipal, Hazardous, and Industrial. CRC Press, pp. 63-103. 
Prudent, P., Domeizel, M., Massiani, C., 1996. Chemical sequential extraction as decision-making tool: Application to municipal solid waste and its individual constituents. Sci. Total Environ. 178, 55-61. doi:10.1016/0048-9697(95)04797-2

Riber, C., Fredriksen, G.S., Christensen, T.H., 2005. Heavy metal content of combustible municipal solid waste in Denmark. Waste Manag. Res. 23, 126-132. doi:10.1177/0734242X05051195

Riber, C., Petersen, C., Christensen, T.H., 2009. Chemical composition of material fractions in Danish household waste. Waste Manag. 29, 1251-7. doi:10.1016/j.wasman.2008.09.013

RIVM (Rijksinstituut voor volksgezondheid en milieu), 1999. Chemische analyse van huishoudelijk restafvalResultaten 1994 en 1995 (Chemical analysis of household residual waste- results 1994 and 1994). Dutch national institute of public health and the environment.

Rizza, C.S., 2011. Analisi ottimizzazione di un inceneritore di rifiuti (Optimization of a waste incinerator), BSc Thesis. Università degli studi di Padova (Italy).

Rotter, V.S., 2002. Schwermetalle in Haushaltsabfällen (Heavy metals in household waste), PhD Thesis. Technische Universität Dresden (Germany).

SAEFL (Swiss Agency for the Environmnet, Forests and Landscape), 2004. A survey of the composition of household waste 2001/02. Environ. Ser. No. 356.

Savary, B., Vincent, R., Rodriguez, C., Chollot, A., 2004. Caractérisation des risques chimiques professionnels de la filière de gestion des déchets: Analyse à priori des risques potentiels (Characterization of chemical hazards for workers in the waste managment industry: A priori analysis of the potential risks). Institut national de Recherche et de Sécurité (INRS).

Shahid, M., Nergis, Y., Siddiqui, S.A., Choudhry, A.F., 2015. Environmental Impact of Municipal Solid Waste in Karachi City 29, 1516-1526. doi:10.5829/idosi.wasj.2014.29.12.1908

Sundberg, C., Franke-Whittle, I.H., Kauppi, S., Yu, D., Romantschuk, M., Insam, H., Jönsson, H., 2011. Characterisation of source-separated household waste intended for composting. Bioresour. Technol. 102, 2859-67. doi:10.1016/j.biortech.2010.10.075

Sørum, L., Skreiberg, Ø., Glarborg, P., Jensen, A., Dam-Johansen, K., 2001. Formation of NO from combustion of volatiles from municipal solid wastes. Combust. Flame 124, 195-212. doi:10.1016/S00102180(00)00194-2

Tchobanoglous, G., Theisen, H., Vigil, S., 1993. Integrated Solid Waste Management. McGraw-Hill, Inc.

Topanou, N., 2011. Characterization of Household Solid Waste in the Town of Abomey - Calavi in Benin. J. Environ. Prot. (Irvine,. Calif). 02, 692-699. doi:10.4236/jep.2011.26080

Veeken, A., Hamelers, B., 2002. Sources of Cd, Cu, Pb and Zn in biowaste. Sci. Total Environ. 300, 87-98.

Wani, K. a., Mamta, Rao, R.J., 2013. Bioconversion of garden waste, kitchen waste and cow dung into valueadded products using earthworm Eisenia fetida. Saudi J. Biol. Sci. 20, 149-154. doi:10.1016/j.sjbs.2013.01.001 
WRAP (Waste \& Resources Action Programme), 2010. Food waste Chemical Analysis- Final Report.

Xiao, G., Ni, M., Chi, Y., Jin, B., Xiao, R., Zhong, Z., Huang, Y., 2009. Gasification characteristics of MSW and an ANN prediction model. Waste Manag. 29, 240-4. doi:10.1016/j.wasman.2008.02.022

Youcai, Z., Lijie, S., Guojian, L., 2002. Chemical stabilization of MSW incinerator fly ashes. J. Hazard. Mater. 95, 47-63. doi:10.1016/S0304-3894(02)00002-X

Zhang, H., He, P.-J., Shao, L.-M., 2008a. Fate of heavy metals during municipal solid waste incineration in Shanghai. J. Hazard. Mater. 156, 365-73. doi:10.1016/j.jhazmat.2007.12.025

Zhang, H., He, P.-J., Shao, L.-M., 2008b. Implication of heavy metals distribution for a municipal solid waste management system--a case study in Shanghai. Sci. Total Environ. 402, 257-267. doi:10.1016/j.scitotenv.2008.04.047

Zhang, H., He, P.-J., Shao, L.-M., Lee, D.-J., 2008c. Source Analysis of Heavy Metals and Arsenic in Organic Fractions of Municipal Solid Waste in a Mega-City (Shanghai). Environ. Sci. Technol. 42, 1586-1593. doi:10.1021/es702303x

Zhang, R., El-Mashad, H., Hartman, K., Wang, F., Rapport, J., Choate, C., Gamble, P., 2005. Anaerobic phased solids digester pilot demonstration project: Characterization of food and green wastes as a feedstock for anaerobic digesters, California Energy Commission.

Zhang, R., El-Mashad, H.M., Hartman, K., Wang, F., Liu, G., Choate, C., Gamble, P., 2007. Characterization of food waste as feedstock for anaerobic digestion. Bioresour. Technol. 98, 929-35.

doi:10.1016/j.biortech.2006.02.039

Zhao, Y., Christensen, T.H., Lu, W., Wu, H., Wang, H., 2011. Environmental impact assessment of solid waste management in Beijing City, China. Waste Manag. 31, 793-9. doi:10.1016/j.wasman.2010.11.007

Zhao, Y., Xing, W., Lu, W., Zhang, X., Christensen, T.H., 2012. Environmental impact assessment of the incineration of municipal solid waste with auxiliary coal in China. Waste Manag. 32, 1989-98. doi:10.1016/j.wasman.2012.05.012

Zhou, H., Meng, A., Long, Y., Li, Q., Zhang, Y., 2014. An overview of characteristics of municipal solid waste fuel in China: Physical, chemical composition and heating value. Renew. Sustain. Energy Rev. 36, 107122. doi:10.1016/j.rser.2014.04.024

Zischka, M., Kettisch, P., Kainrath, P., 1998. Microwave-assisted digestion of plastic scrap: basic considerations and chemical approach. At. Spectrosc. 19, 223-227.

Øygard, J.K., Måge, A., Gjengedal, E., 2004. Estimation of the mass-balance of selected metals in four sanitary landfills in Western Norway, with emphasis on the heavy metal content of the deposited waste and the leachate. Water Res. 38, 2851-8. doi:10.1016/j.watres.2004.03.036 
Table A4: Found data entries per parameter and material fraction

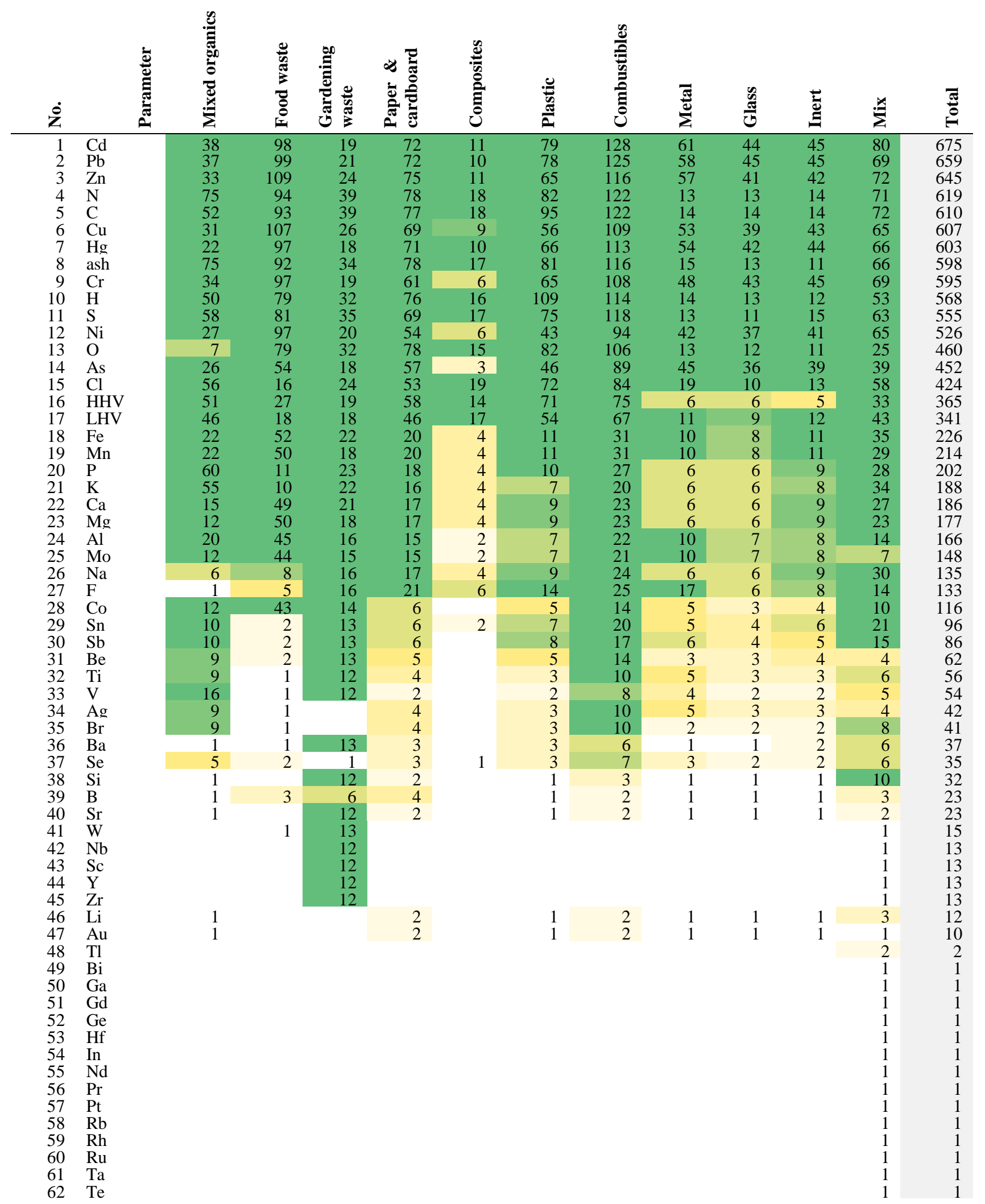


Table A5: Frequency of waste characterization approaches employed for the individual parameters and for the respective element group expressed as $\%$ of data points

\begin{tabular}{|c|c|c|c|c|}
\hline Element & Direct chemical analysis & Mass balances & Secondary data reporting & Unreported methods \\
\hline Heavy metals/toxic elements & $76 \%$ & $6 \%$ & $8 \%$ & $9 \%$ \\
\hline $\mathrm{Pb}$ & $78 \%$ & $2 \%$ & $15 \%$ & $5 \%$ \\
\hline $\mathrm{Zn}$ & $79 \%$ & $2 \%$ & $8 \%$ & $11 \%$ \\
\hline $\mathrm{Cu}$ & $76 \%$ & $2 \%$ & $9 \%$ & $12 \%$ \\
\hline $\mathrm{Hg}$ & $71 \%$ & $2 \%$ & $17 \%$ & $11 \%$ \\
\hline $\mathrm{Cr}$ & $66 \%$ & $2 \%$ & $19 \%$ & $12 \%$ \\
\hline $\mathrm{Ni}$ & $76 \%$ & $3 \%$ & $8 \%$ & $13 \%$ \\
\hline $\mathrm{Al}$ & $86 \%$ & $8 \%$ & $1 \%$ & $5 \%$ \\
\hline $\mathrm{Fe}$ & $75 \%$ & $5 \%$ & $3 \%$ & $17 \%$ \\
\hline $\mathrm{Mn}$ & $78 \%$ & $3 \%$ & $2 \%$ & $17 \%$ \\
\hline Mo & $88 \%$ & $7 \%$ & $1 \%$ & $3 \%$ \\
\hline Co & $84 \%$ & $9 \%$ & $2 \%$ & $5 \%$ \\
\hline $\mathrm{Sb}$ & $48 \%$ & $11 \%$ & $28 \%$ & $13 \%$ \\
\hline $\mathrm{V}$ & $86 \%$ & $8 \%$ & $0 \%$ & $7 \%$ \\
\hline $\mathrm{Be}$ & $89 \%$ & $5 \%$ & $0 \%$ & $6 \%$ \\
\hline $\mathrm{Ba}$ & $71 \%$ & $27 \%$ & $0 \%$ & $2 \%$ \\
\hline $\mathrm{Cd}$ & $72 \%$ & $2 \%$ & $15 \%$ & $10 \%$ \\
\hline As & $74 \%$ & $3 \%$ & $14 \%$ & $9 \%$ \\
\hline Nutrients \& CHNO elements & $61 \%$ & $4 \%$ & $12 \%$ & $23 \%$ \\
\hline $\mathrm{C}$ & $56 \%$ & $1 \%$ & $20 \%$ & $23 \%$ \\
\hline $\mathrm{H}$ & $52 \%$ & $1 \%$ & $24 \%$ & $23 \%$ \\
\hline $\mathrm{N}$ & $58 \%$ & $0 \%$ & $19 \%$ & $23 \%$ \\
\hline $\mathrm{O}$ & $51 \%$ & $1 \%$ & $25 \%$ & $23 \%$ \\
\hline $\mathrm{Ca}$ & $75 \%$ & $6 \%$ & $2 \%$ & $18 \%$ \\
\hline S & $54 \%$ & $1 \%$ & $20 \%$ & $25 \%$ \\
\hline K & $74 \%$ & $6 \%$ & $2 \%$ & $19 \%$ \\
\hline $\mathrm{Mg}$ & $76 \%$ & $6 \%$ & $2 \%$ & $16 \%$ \\
\hline $\mathrm{Na}$ & $67 \%$ & $8 \%$ & $4 \%$ & $22 \%$ \\
\hline Se & $41 \%$ & $8 \%$ & $10 \%$ & $41 \%$ \\
\hline $\mathrm{P}$ & $72 \%$ & $4 \%$ & $1 \%$ & $22 \%$ \\
\hline Energy (conversion) parameters & $61 \%$ & $4 \%$ & $14 \%$ & $20 \%$ \\
\hline ash & $57 \%$ & $0 \%$ & $23 \%$ & $21 \%$ \\
\hline LHV & $58 \%$ & $1 \%$ & $17 \%$ & $24 \%$ \\
\hline HHV & $55 \%$ & $0 \%$ & $27 \%$ & $18 \%$ \\
\hline $\mathrm{Cl}$ & $43 \%$ & $3 \%$ & $9 \%$ & $45 \%$ \\
\hline $\mathrm{F}$ & $70 \%$ & $10 \%$ & $11 \%$ & $9 \%$ \\
\hline $\mathrm{Br}$ & $84 \%$ & $11 \%$ & $0 \%$ & $5 \%$ \\
\hline
\end{tabular}


Table A5 (continued): Frequency of waste characterization approaches employed for the individual parameters and for the respective element group expressed as \% of data points

\begin{tabular}{|c|c|c|c|c|}
\hline Element & Direct chemical analysis & Mass balances & Secondary data reporting & Unreported methods \\
\hline High-tech application elements & $33 \%$ & $63 \%$ & $1 \%$ & $3 \%$ \\
\hline $\mathrm{Sn}$ & $66 \%$ & $14 \%$ & $1 \%$ & $19 \%$ \\
\hline $\mathrm{Ti}$ & $78 \%$ & $14 \%$ & $2 \%$ & $6 \%$ \\
\hline Ag & $80 \%$ & $7 \%$ & $0 \%$ & $13 \%$ \\
\hline B & $52 \%$ & $0 \%$ & $16 \%$ & $32 \%$ \\
\hline $\mathrm{Sr}$ & $78 \%$ & $22 \%$ & $0 \%$ & $0 \%$ \\
\hline W & $71 \%$ & $18 \%$ & $12 \%$ & $0 \%$ \\
\hline $\mathrm{Nb}$ & $80 \%$ & $20 \%$ & $0 \%$ & $0 \%$ \\
\hline Sc & $80 \%$ & $20 \%$ & $0 \%$ & $0 \%$ \\
\hline Y & $80 \%$ & $20 \%$ & $0 \%$ & $0 \%$ \\
\hline $\mathrm{Zr}$ & $80 \%$ & $20 \%$ & $0 \%$ & $0 \%$ \\
\hline $\mathrm{Li}$ & $50 \%$ & $50 \%$ & $0 \%$ & $0 \%$ \\
\hline $\mathrm{Au}$ & $75 \%$ & $25 \%$ & $0 \%$ & $0 \%$ \\
\hline $\mathrm{Bi}$ & $0 \%$ & $100 \%$ & $0 \%$ & $0 \%$ \\
\hline $\mathrm{Ga}$ & $0 \%$ & $100 \%$ & $0 \%$ & $0 \%$ \\
\hline Gd & $0 \%$ & $100 \%$ & $0 \%$ & $0 \%$ \\
\hline Ge & $0 \%$ & $100 \%$ & $0 \%$ & $0 \%$ \\
\hline $\mathrm{Hf}$ & $0 \%$ & $100 \%$ & $0 \%$ & $0 \%$ \\
\hline In & $0 \%$ & $100 \%$ & $0 \%$ & $0 \%$ \\
\hline $\mathrm{Nd}$ & $0 \%$ & $100 \%$ & $0 \%$ & $0 \%$ \\
\hline Pr & $0 \%$ & $100 \%$ & $0 \%$ & $0 \%$ \\
\hline $\mathrm{Pt}$ & $0 \%$ & $100 \%$ & $0 \%$ & $0 \%$ \\
\hline $\mathrm{Rb}$ & $0 \%$ & $100 \%$ & $0 \%$ & $0 \%$ \\
\hline $\mathrm{Rh}$ & $0 \%$ & $100 \%$ & $0 \%$ & $0 \%$ \\
\hline $\mathrm{Ru}$ & $0 \%$ & $100 \%$ & $0 \%$ & $0 \%$ \\
\hline Та & $0 \%$ & $100 \%$ & $0 \%$ & $0 \%$ \\
\hline $\mathrm{Te}$ & $0 \%$ & $100 \%$ & $0 \%$ & $0 \%$ \\
\hline
\end{tabular}


Table A6: Number of database entries from Africa

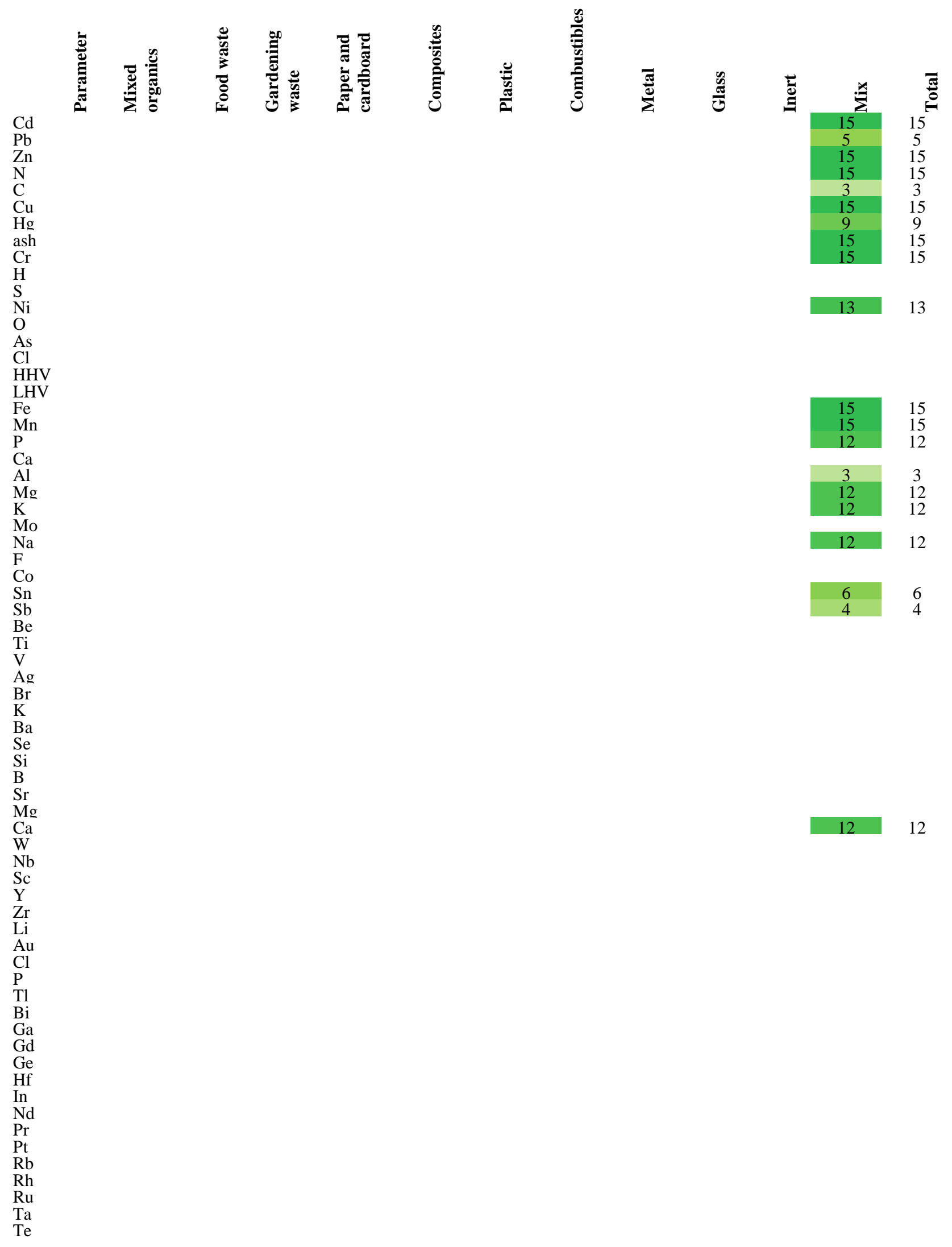


Table A7: Number of database entries from America-north

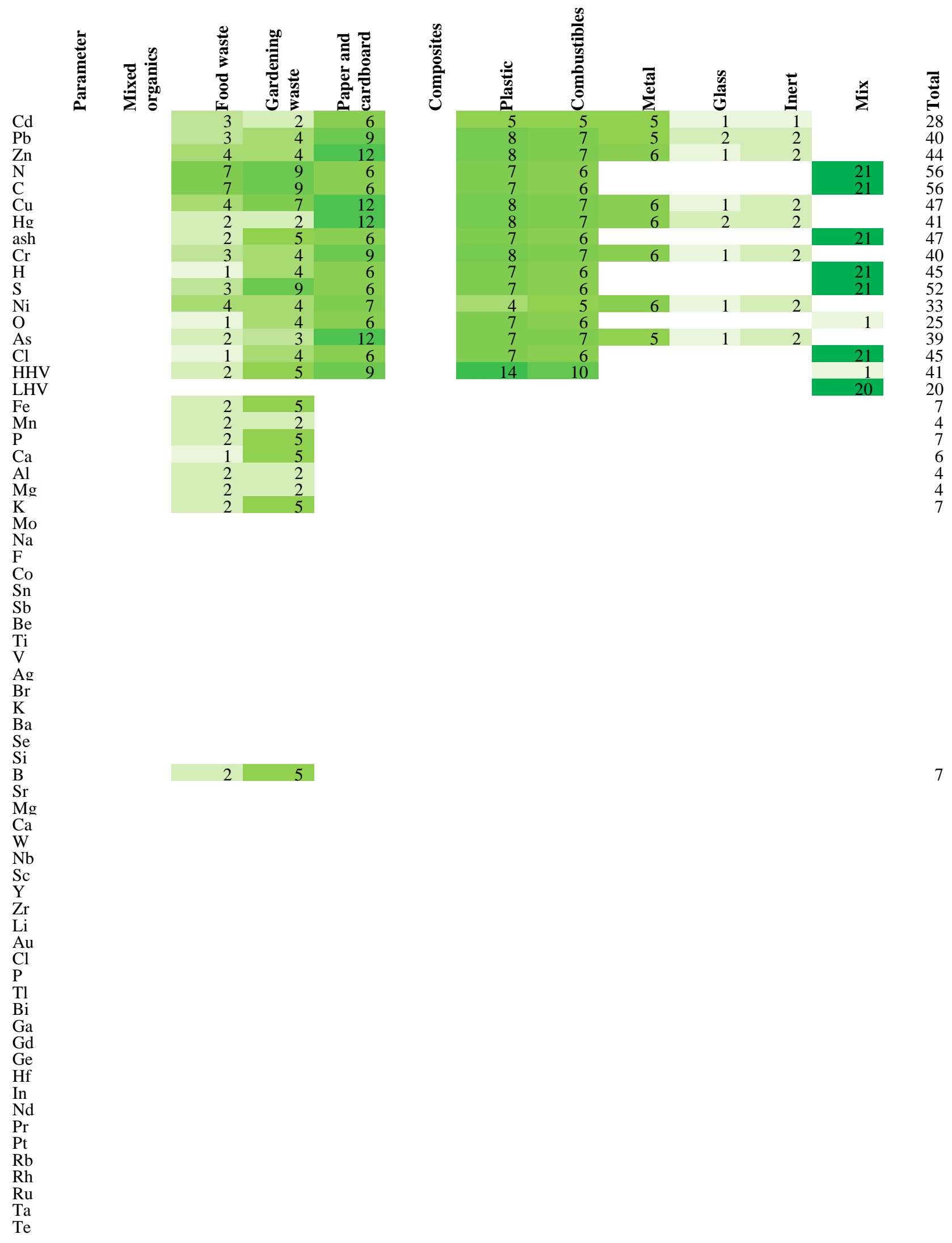


Table A8: Number of database entries from America-south

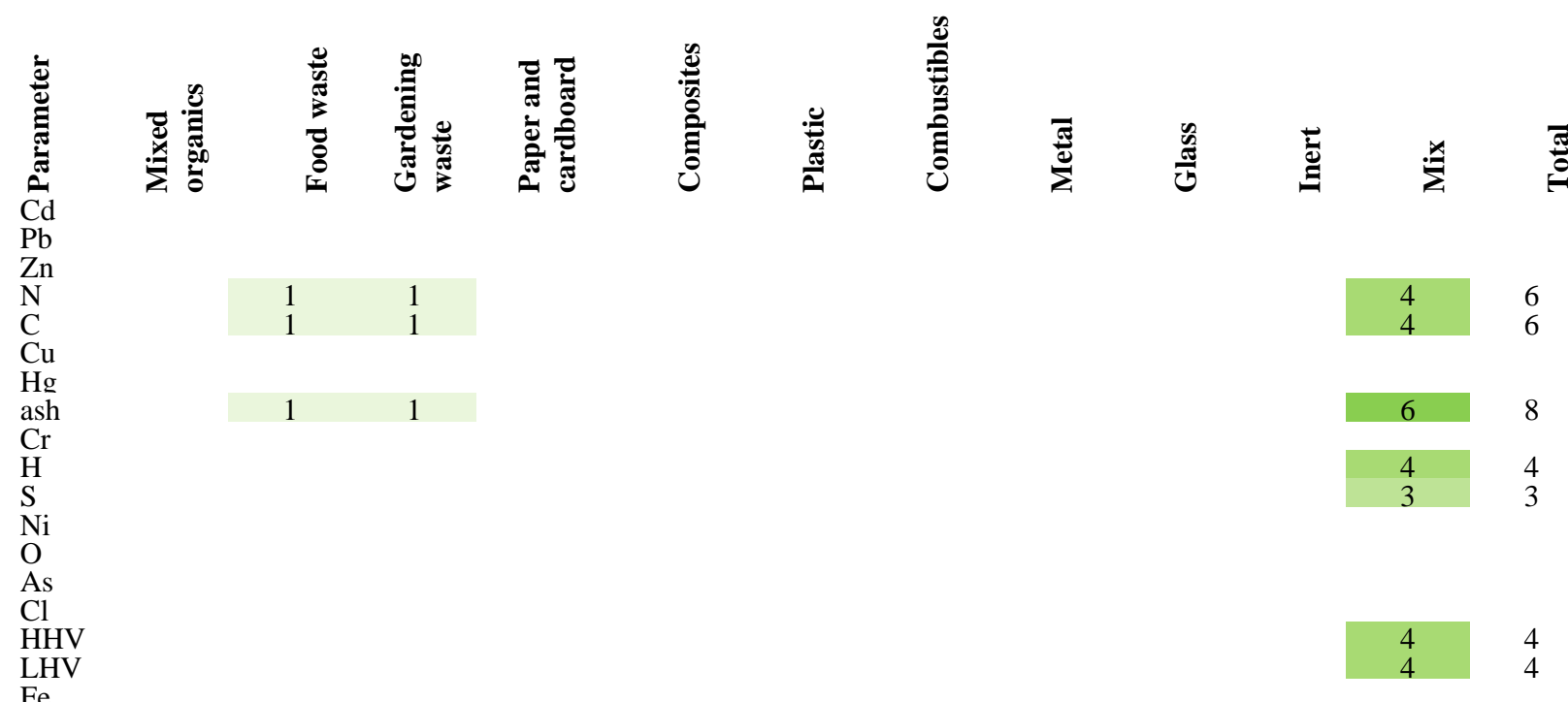


Table A9: Number of database entries from Asia

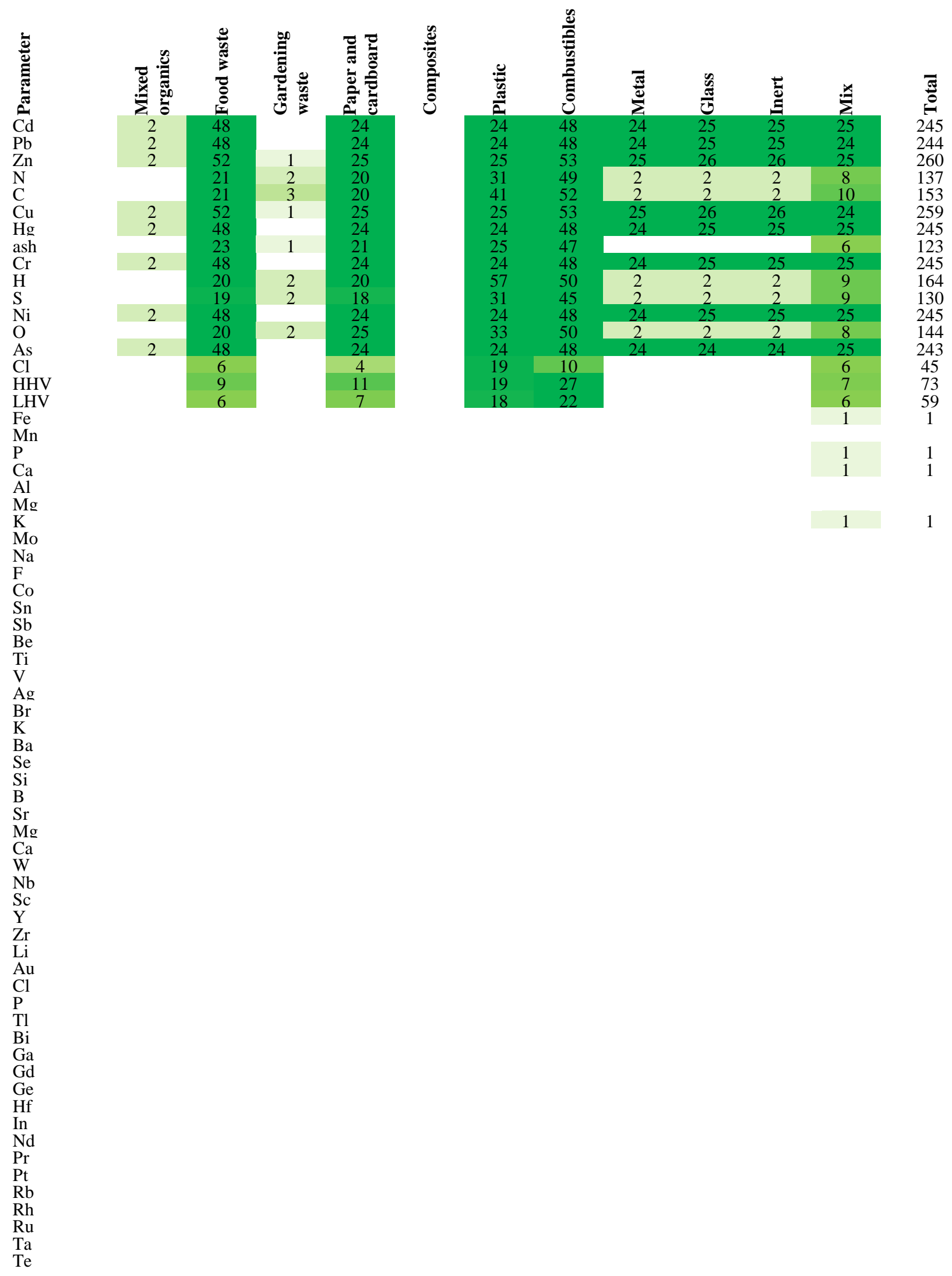


Table A10: Number of database entries from Europe

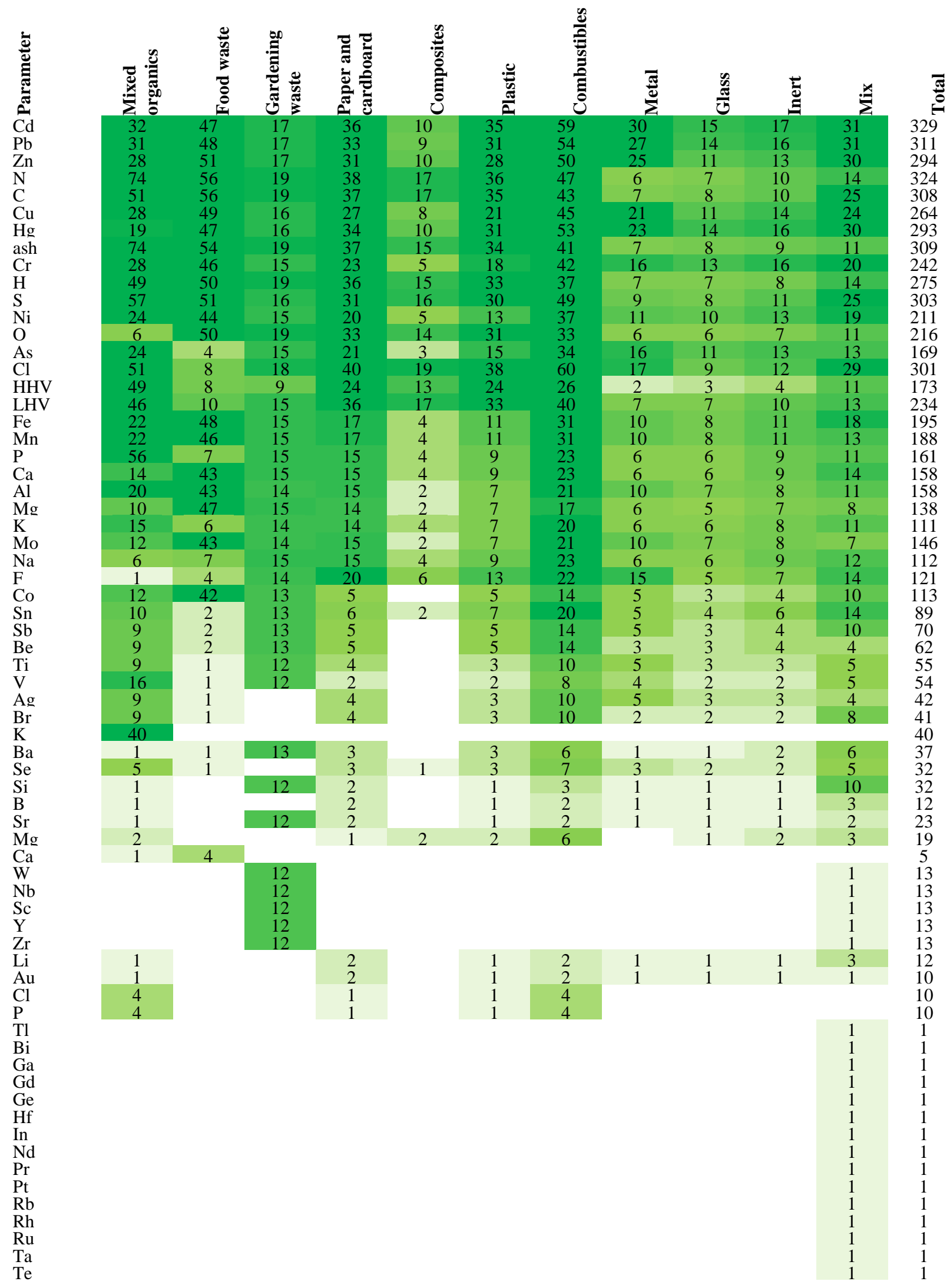


Table A11: Number of database entries from Middle East

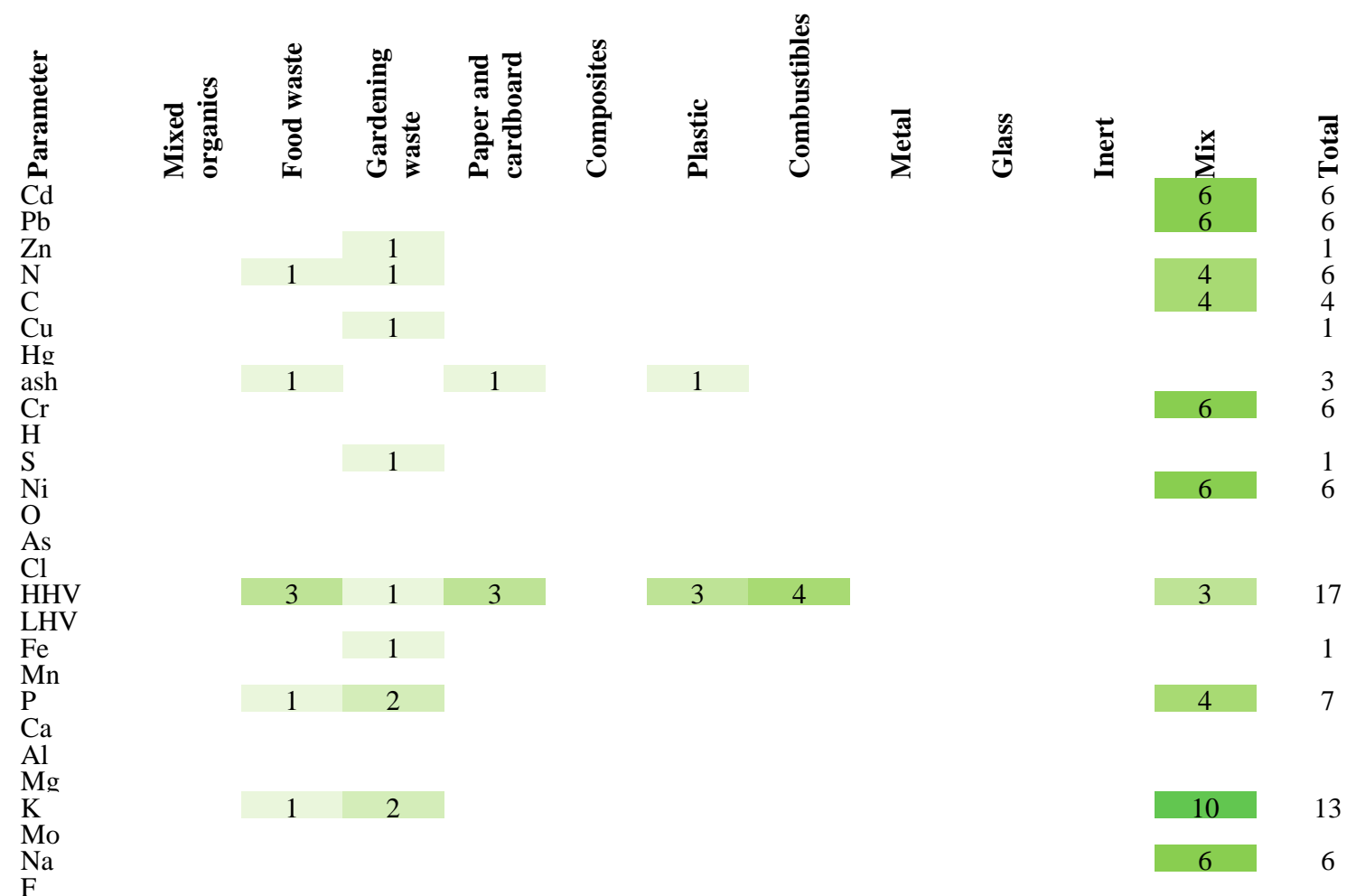


Table A12: Number of database entries from secondary data reporting

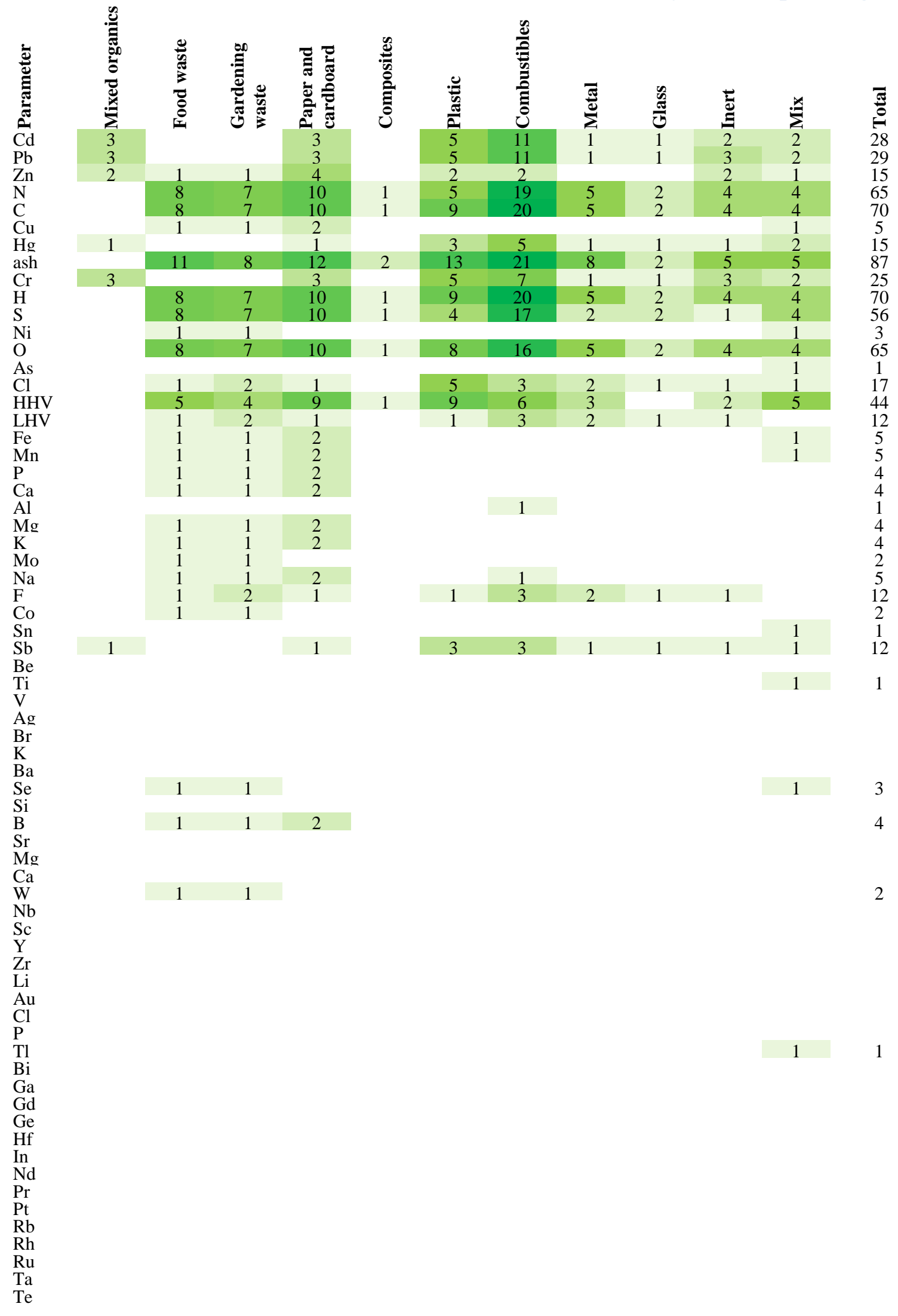


Table A13: Number of database entries from unknown regional origin

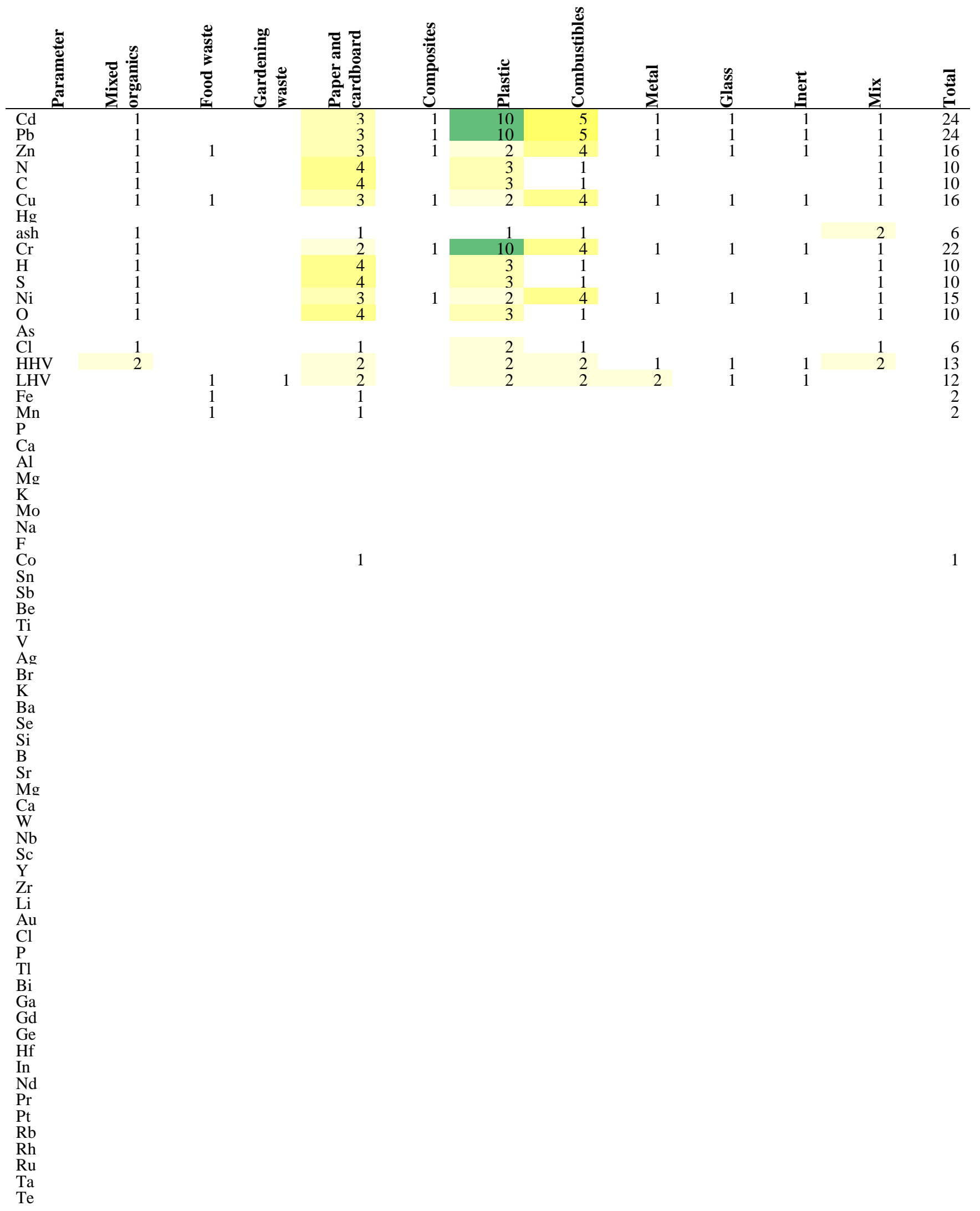




\title{
Appendix B
}

for

\section{Physico-chemical characterisation of material fractions in household waste: overview of data in literature}

\author{
Ramona Götze*, Alessio Boldrin, Charlotte Scheutz, Thomas Fruergaard Astrup \\ Department of Environmental Engineering, Technical University of Denmark, Building 113, 2800 Kgs. Lyngby, \\ Denmark \\ *Corresponding author’s e-mail: rmog@env.dtu.dk
}

\section{Quantiles for each parameter (in alphabetical order)}




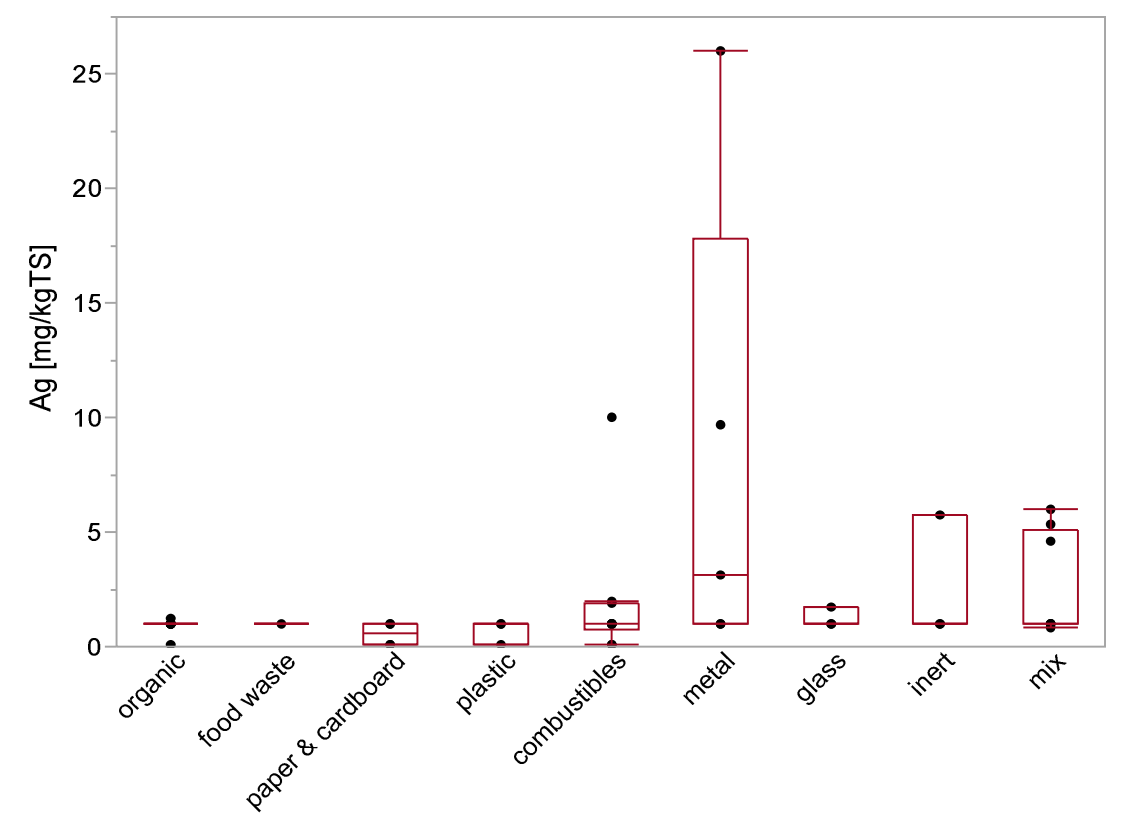

Waste Material Fractions

\section{Quantiles [mg/kgTS]}

\begin{tabular}{|c|c|c|c|c|c|c|c|c|c|}
\hline $\begin{array}{c}\text { Waste Material } \\
\text { Fraction }\end{array}$ & n_data* & $\mathrm{n}_{-}<\mathrm{DL} * *$ & Min & $10 \%$ & $25 \%$ & Median & $75 \%$ & $90 \%$ & Max \\
\hline organic & 9 & 7 & 0.08 & 0.08 & 1.00 & 1.00 & 1.00 & 1.20 & 1.20 \\
\hline food waste & 1 & 1 & 1.00 & 1.00 & 1.00 & 1.00 & 1.00 & 1.00 & 1.00 \\
\hline gardening waste & - & - & - & - & - & - & - & - & - \\
\hline paper \& cardboard & 4 & 3 & 0.08 & 0.08 & 0.09 & 0.56 & 1.00 & 1.00 & 1.00 \\
\hline composites & - & - & - & - & - & - & - & - & - \\
\hline plastic & 3 & 3 & 0.08 & 0.08 & 0.08 & 1.00 & 1.00 & 1.00 & 1.00 \\
\hline combustibles & 10 & 7 & 0.08 & 0.08 & 0.77 & 1.00 & 1.93 & 9.20 & 10.00 \\
\hline metal & 5 & 4 & 1.00 & 1.00 & 1.00 & 3.14 & 17.85 & 26.00 & 26.00 \\
\hline glass & 3 & 2 & 1.00 & 1.00 & 1.00 & 1.00 & 1.71 & 1.71 & 1.71 \\
\hline inert & 3 & 2 & 1.00 & 1.00 & 1.00 & 1.00 & 5.78 & 5.78 & 5.78 \\
\hline $\operatorname{mix}$ & 8 & 4 & 0.86 & 0.86 & 1.00 & 1.00 & 5.12 & 6.02 & 6.02 \\
\hline Total & 46 & 33 & & & & & & & \\
\hline
\end{tabular}




\section{Value ranges for $\mathrm{Al}$}

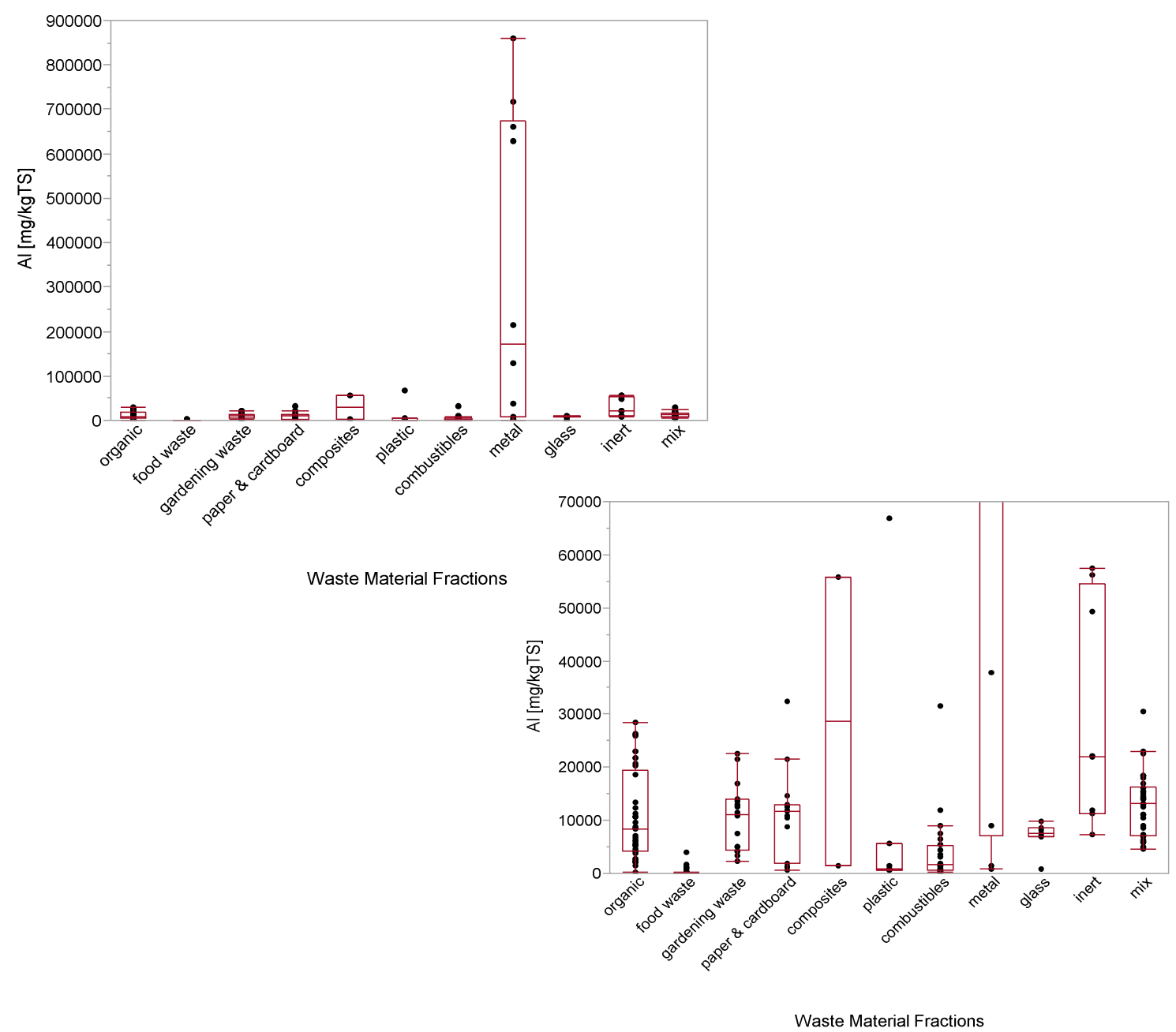

Quantiles [mg/kgTS]

\begin{tabular}{|c|c|c|c|c|c|c|c|c|c|}
\hline $\begin{array}{l}\text { Waste Material } \\
\text { Fraction }\end{array}$ & n_data* & $\mathbf{n}_{-}<\mathrm{DL}^{* *}$ & Min & $10 \%$ & $25 \%$ & Median & $75 \%$ & $90 \%$ & Max \\
\hline organic & 41 & - & 286 & 2160 & 4100 & 8400 & 19464 & 25412 & 28333 \\
\hline food waste & 47 & - & 12 & 21 & 30 & 46 & 103 & 851 & 3890 \\
\hline gardening waste & 16 & - & 2360 & 3088 & 4453 & 11178 & 13916 & 21859 & 22550 \\
\hline paper \& cardboard & 15 & - & 681 & 1033 & 1800 & 11700 & 12933 & 25870 & 32425 \\
\hline composites & 2 & - & 1430 & 1430 & 1430 & 28615 & 55800 & 55800 & 55800 \\
\hline plastic & 7 & - & 692 & 692 & 720 & 820 & 5650 & 66800 & 66800 \\
\hline combustibles & 24 & - & 200 & 250 & 678 & 1570 & 5150 & 10500 & 31600 \\
\hline metal & 10 & - & 860 & 926 & 7055 & 171500 & 674500 & 846700 & 861000 \\
\hline glass & 7 & - & 750 & 750 & 6860 & 7620 & 8470 & 9870 & 9870 \\
\hline inert & 8 & - & 7300 & 7300 & 11361 & 22000 & 54483 & 57500 & 57500 \\
\hline mix & 34 & - & 4670 & 5435 & 7118 & 13080 & 16280 & 20478 & 30500 \\
\hline
\end{tabular}

Grand Total

209

*) number of data points

$\left.{ }^{\star \star}\right)$ number of values below the detection limit 


\section{Value ranges for As}

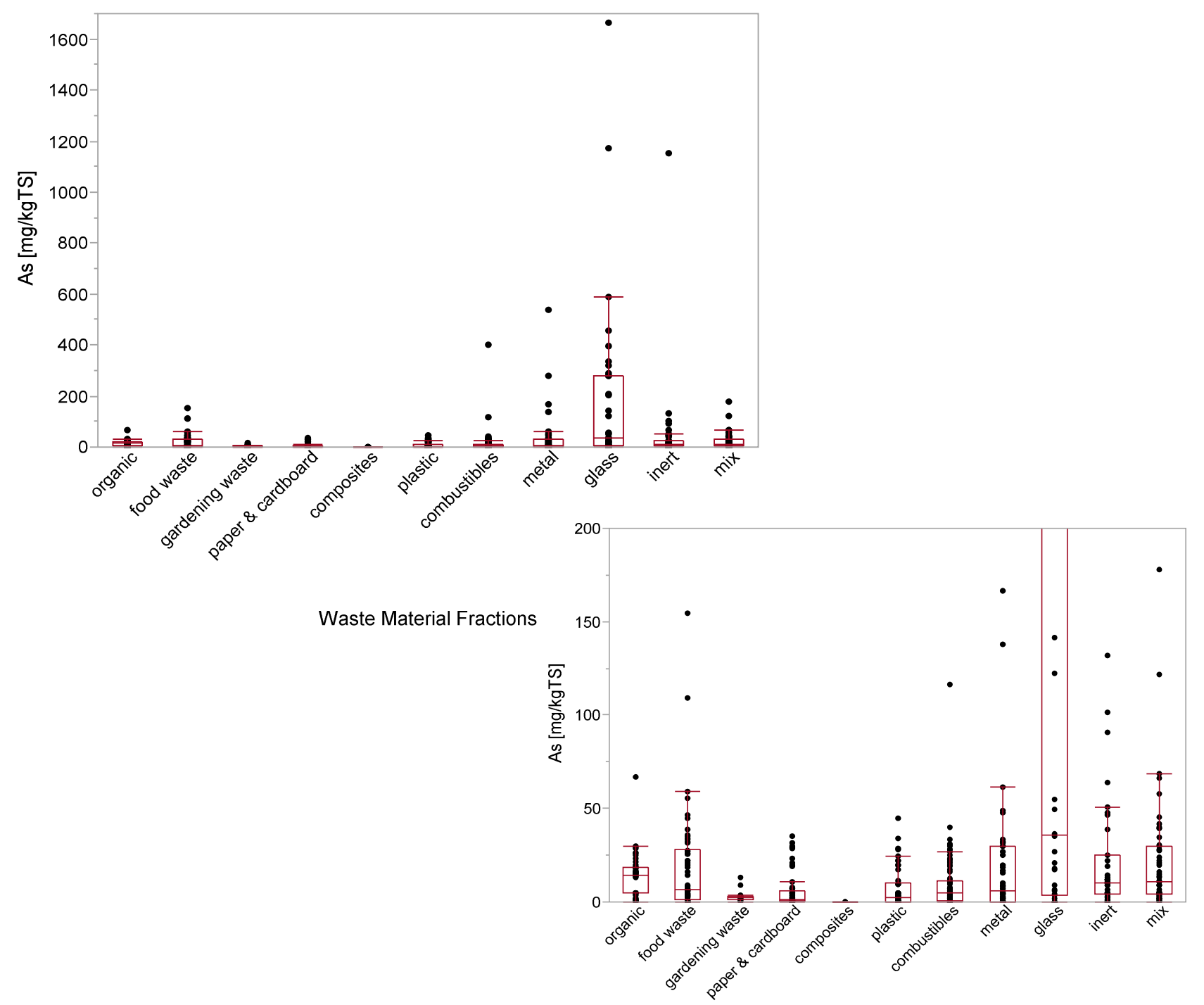

\section{Quantiles [mg/kgTS]}

\begin{tabular}{|c|c|c|c|c|c|c|c|c|c|}
\hline \multirow{2}{*}{$\begin{array}{c}\text { Waste Material } \\
\text { Fraction }\end{array}$} & \multirow[b]{2}{*}{ n_data* } & \multirow[b]{2}{*}{$\mathrm{n}_{-}<\mathrm{DL} * *$} & \multirow[b]{2}{*}{ Min } & \multicolumn{6}{|c|}{ Waste Material Fractions } \\
\hline & & & & $10 \%$ & $25 \%$ & Median & $75 \%$ & $90 \%$ & $\operatorname{Max}$ \\
\hline organic & 48 & 8 & 0.200 & 0.699 & 5.000 & 14.565 & 18.605 & 26.385 & 67.000 \\
\hline food waste & 54 & 1 & 0.000 & 0.000 & 1.000 & 6.750 & 28.350 & 45.550 & 154.400 \\
\hline gardening waste & 18 & - & 0.000 & 0.495 & 1.188 & 2.405 & 3.080 & 9.582 & 13.020 \\
\hline paper \& cardboard & 57 & 4 & 0.000 & 0.126 & 0.345 & 1.090 & 6.100 & 24.100 & 35.100 \\
\hline composites & 3 & - & 0.140 & 0.140 & 0.140 & 0.200 & 0.200 & 0.200 & 0.200 \\
\hline plastic & 46 & 5 & 0.000 & 0.000 & 0.215 & 2.250 & 10.075 & 25.580 & 44.800 \\
\hline combustibles & 89 & 10 & 0.000 & 0.000 & 0.305 & 5.000 & 11.340 & 28.170 & 400.000 \\
\hline metal & 45 & 1 & 0.000 & 0.000 & 0.000 & 6.200 & 29.800 & 92.040 & 539.000 \\
\hline glass & 36 & - & 0.000 & 0.000 & 3.800 & 35.900 & 280.475 & 497.680 & 1664.400 \\
\hline inert & 39 & 2 & 0.000 & 0.000 & 4.000 & 10.400 & 25.000 & 91.000 & 1153.000 \\
\hline $\operatorname{mix}$ & 50 & 2 & 0.000 & 1.633 & 4.060 & 10.950 & 30.068 & 56.465 & 177.990 \\
\hline
\end{tabular}

*) number of data points

${ }^{* *}$ ) number of values below the detection limit 


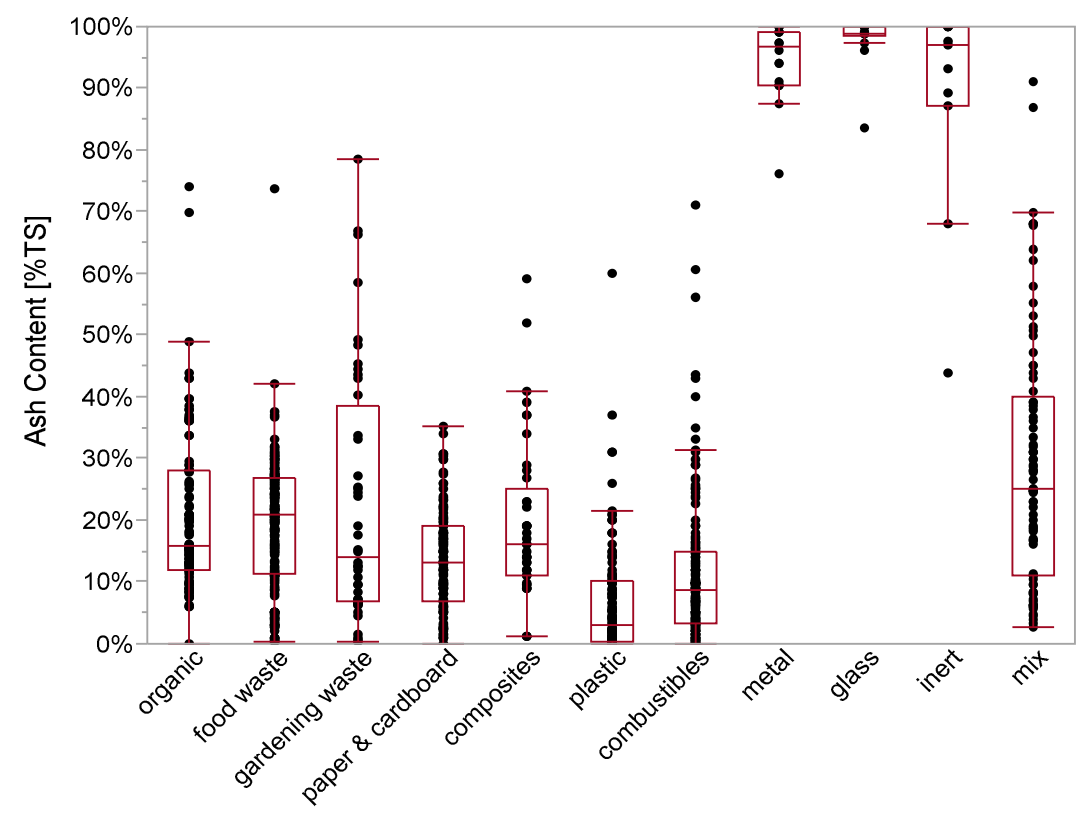

Waste Material Fractions

\section{Quantiles [\%TS]}

\begin{tabular}{|c|c|c|c|c|c|c|c|c|c|}
\hline $\begin{array}{l}\text { Waste Material } \\
\text { Fraction }\end{array}$ & n_data* & $\mathrm{n}_{-}<\mathrm{DL}$ ** & Min & $10 \%$ & $25 \%$ & Median & $75 \%$ & $90 \%$ & Max \\
\hline organic & 106 & - & $0.0 \%$ & $8.5 \%$ & $12.0 \%$ & $15.7 \%$ & $28.0 \%$ & $38.0 \%$ & $74.0 \%$ \\
\hline food waste & 196 & - & $0.2 \%$ & $3.8 \%$ & $11.5 \%$ & $20.9 \%$ & $26.9 \%$ & $30.0 \%$ & $73.7 \%$ \\
\hline gardening waste & 44 & - & $0.4 \%$ & $3.0 \%$ & $6.8 \%$ & $14.0 \%$ & $38.6 \%$ & $53.9 \%$ & $78.4 \%$ \\
\hline paper \& cardboard & 112 & - & $0.0 \%$ & $2.4 \%$ & $6.8 \%$ & $13.0 \%$ & $19.0 \%$ & $25.7 \%$ & $35.4 \%$ \\
\hline composites & 41 & - & $1.2 \%$ & $9.0 \%$ & $11.0 \%$ & $16.0 \%$ & $25.0 \%$ & $38.6 \%$ & $59.0 \%$ \\
\hline plastic & 119 & - & $0.0 \%$ & $0.1 \%$ & $0.4 \%$ & $3.0 \%$ & $10.0 \%$ & $18.0 \%$ & $60.0 \%$ \\
\hline combustibles & 146 & - & $0.0 \%$ & $1.0 \%$ & $3.2 \%$ & $8.7 \%$ & $15.1 \%$ & $26.6 \%$ & $71.0 \%$ \\
\hline metal & 18 & - & $76.1 \%$ & $86.5 \%$ & $90.5 \%$ & $96.7 \%$ & $99.3 \%$ & $100.0 \%$ & $100.0 \%$ \\
\hline glass & 14 & - & $83.5 \%$ & $89.8 \%$ & $98.5 \%$ & $98.9 \%$ & $100.0 \%$ & $100.0 \%$ & $100.0 \%$ \\
\hline inert & 11 & - & $43.9 \%$ & $48.7 \%$ & $87.2 \%$ & $97.0 \%$ & $100.0 \%$ & $100.0 \%$ & $100.0 \%$ \\
\hline $\operatorname{mix}$ & 85 & - & $2.6 \%$ & $6.1 \%$ & $11.0 \%$ & $25.0 \%$ & $39.9 \%$ & $62.8 \%$ & $91.0 \%$ \\
\hline
\end{tabular}

*) number of data points

${ }^{* *}$ ) number of values below the detection limit 


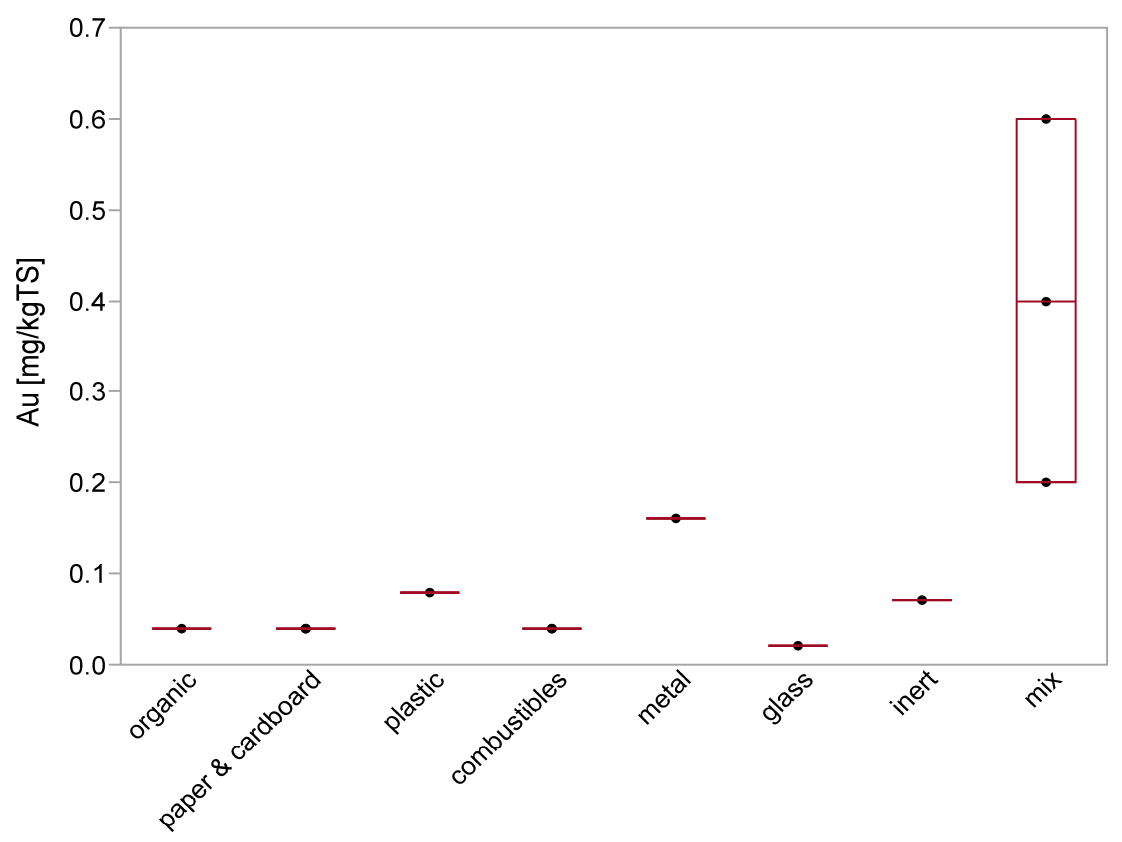

Waste Material Fractions

\section{Quantiles [mg/kgTS]}

\begin{tabular}{|c|c|c|c|c|c|c|c|c|c|}
\hline $\begin{array}{c}\text { Waste Material } \\
\text { Fraction }\end{array}$ & n_data* & $\mathrm{n}_{-}<\mathrm{DL} \mathbf{L}^{* *}$ & Min & $10 \%$ & $25 \%$ & Median & $75 \%$ & $90 \%$ & Max \\
\hline organic & 1 & 1 & 0.04 & 0.04 & 0.04 & 0.04 & 0.04 & 0.04 & 0.04 \\
\hline food waste & - & - & - & - & - & - & - & - & - \\
\hline gardening waste & - & - & - & - & - & - & - & - & - \\
\hline paper \& cardboard & 2 & 2 & 0.04 & 0.04 & 0.04 & 0.04 & 0.04 & 0.04 & 0.04 \\
\hline composites & - & - & - & - & - & - & - & - & - \\
\hline plastic & 1 & 1 & 0.08 & 0.08 & 0.08 & 0.08 & 0.08 & 0.08 & 0.08 \\
\hline combustibles & 2 & 2 & 0.04 & 0.04 & 0.04 & 0.04 & 0.04 & 0.04 & 0.04 \\
\hline metal & 1 & - & 0.16 & 0.16 & 0.16 & 0.16 & 0.16 & 0.16 & 0.16 \\
\hline glass & 1 & 1 & 0.02 & 0.02 & 0.02 & 0.02 & 0.02 & 0.02 & 0.02 \\
\hline inert & 1 & - & 0.07 & 0.07 & 0.07 & 0.07 & 0.07 & 0.07 & 0.07 \\
\hline $\operatorname{mix}$ & 3 & - & 0.20 & 0.20 & 0.20 & 0.40 & 0.60 & 0.60 & 0.60 \\
\hline
\end{tabular}

*) number of data points

$\left.{ }^{\star *}\right)$ number of values below the detection limit 


\section{Value ranges for $B$}

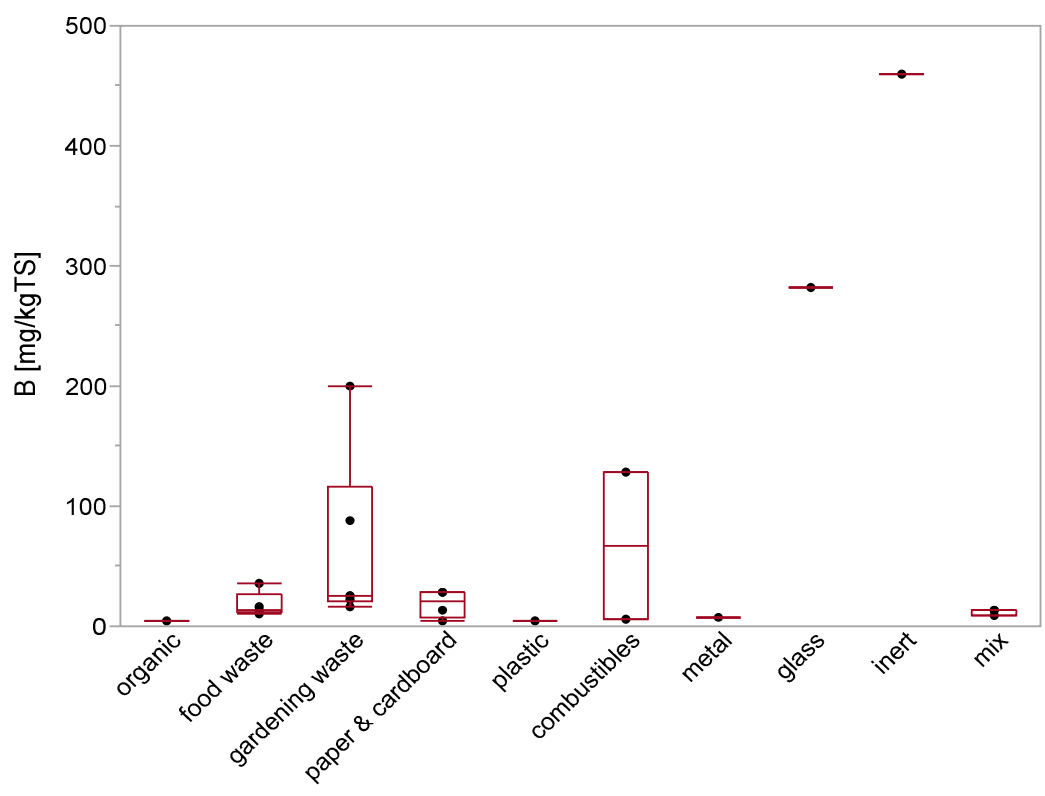

Waste Material Fractions

\section{Quantiles [mg/kgTS]}

\begin{tabular}{|c|c|c|c|c|c|c|c|c|c|}
\hline $\begin{array}{c}\text { Waste Material } \\
\text { Fraction }\end{array}$ & n_data* & $\mathrm{n}_{-}<\mathrm{DL}$ ** & Min & $10 \%$ & $25 \%$ & Median & $75 \%$ & $90 \%$ & Max \\
\hline organic & 1 & - & 5.1 & 5.1 & 5.1 & 5.1 & 5.1 & 5.1 & 5.1 \\
\hline food waste & 5 & - & 11.0 & 11.0 & 11.5 & 13.0 & 26.5 & 36.0 & 36.0 \\
\hline gardening waste & 6 & - & 17.0 & 17.0 & 20.8 & 25.5 & 116.0 & 200.0 & 200.0 \\
\hline paper \& cardboard & 4 & - & 4.6 & 4.6 & 6.9 & 21.0 & 28.5 & 28.7 & 28.7 \\
\hline composites & - & - & - & - & - & - & - & - & - \\
\hline plastic & 1 & - & 4.1 & 4.1 & 4.1 & 4.1 & 4.1 & 4.1 & 4.1 \\
\hline combustibles & 2 & - & 5.6 & 5.6 & 5.6 & 66.8 & 128.0 & 128.0 & 128.0 \\
\hline metal & 1 & - & 7.4 & 7.4 & 7.4 & 7.4 & 7.4 & 7.4 & 7.4 \\
\hline glass & 1 & - & 282.0 & 282.0 & 282.0 & 282.0 & 282.0 & 282.0 & 282.0 \\
\hline inert & 1 & - & 459.0 & 459.0 & 459.0 & 459.0 & 459.0 & 459.0 & 459.0 \\
\hline $\operatorname{mix}$ & 3 & - & 8.6 & 8.6 & 8.6 & 14.0 & 14.0 & 14.0 & 14.0 \\
\hline
\end{tabular}

$\left.{ }^{*}\right)$ number of data points

**) number of values below the detection limit 


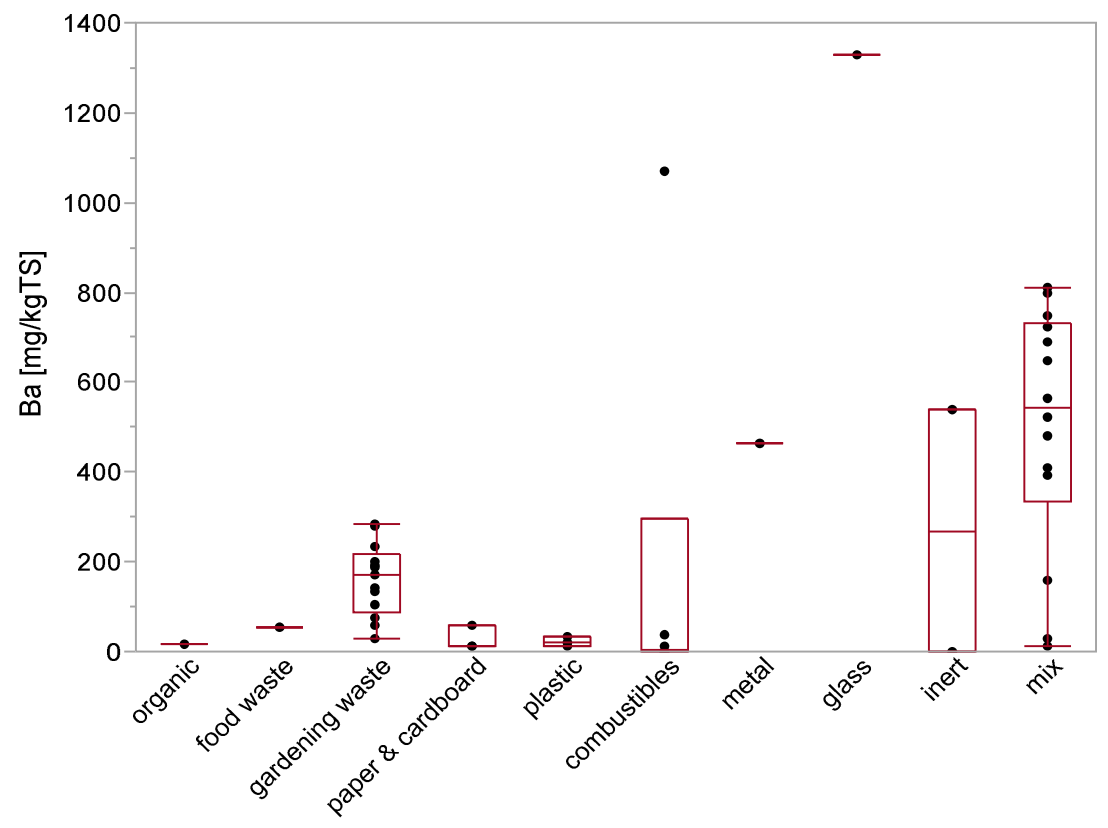

Waste Material Fractions

\section{Quantiles [mg/kgTS]}

\begin{tabular}{|c|c|c|c|c|c|c|c|c|c|}
\hline $\begin{array}{l}\text { Waste Material } \\
\text { Fraction }\end{array}$ & n_data* & $\mathbf{n}_{-}<\mathrm{DL}^{* *}$ & Min & $10 \%$ & $25 \%$ & Median & $75 \%$ & $90 \%$ & Max \\
\hline organic & 1 & - & 18.1 & 18.1 & 18.1 & 18.1 & 18.1 & 18.1 & 18.1 \\
\hline food waste & 1 & - & 55.1 & 55.1 & 55.1 & 55.1 & 55.1 & 55.1 & 55.1 \\
\hline gardening waste & 13 & - & 27.8 & 39.5 & 89.1 & 170.2 & 216.1 & 282.7 & 283.3 \\
\hline paper \& cardboard & 3 & - & 12.3 & 12.3 & 12.3 & 12.5 & 60.1 & 60.1 & 60.1 \\
\hline composites & - & - & - & - & - & - & - & - & - \\
\hline plastic & 3 & - & 12.8 & 12.8 & 12.8 & 22.5 & 33.4 & 33.4 & 33.4 \\
\hline combustibles & 6 & - & 0.0 & 0.0 & 0.0 & 5.3 & 297.5 & 1071.0 & 1071.0 \\
\hline metal & 1 & - & 464.0 & 464.0 & 464.0 & 464.0 & 464.0 & 464.0 & 464.0 \\
\hline glass & 1 & - & 1330.0 & 1330.0 & 1330.0 & 1330.0 & 1330.0 & 1330.0 & 1330.0 \\
\hline inert & 2 & - & 0.0 & 0.0 & 0.0 & 269.5 & 539.0 & 539.0 & 539.0 \\
\hline $\operatorname{mix}$ & 14 & - & 13.6 & 21.0 & 335.8 & 543.5 & 730.0 & 804.5 & 809.0 \\
\hline Grand Total & 45 & 0 & & & & & & & \\
\hline
\end{tabular}




\section{Value ranges for $\mathrm{Be}$}

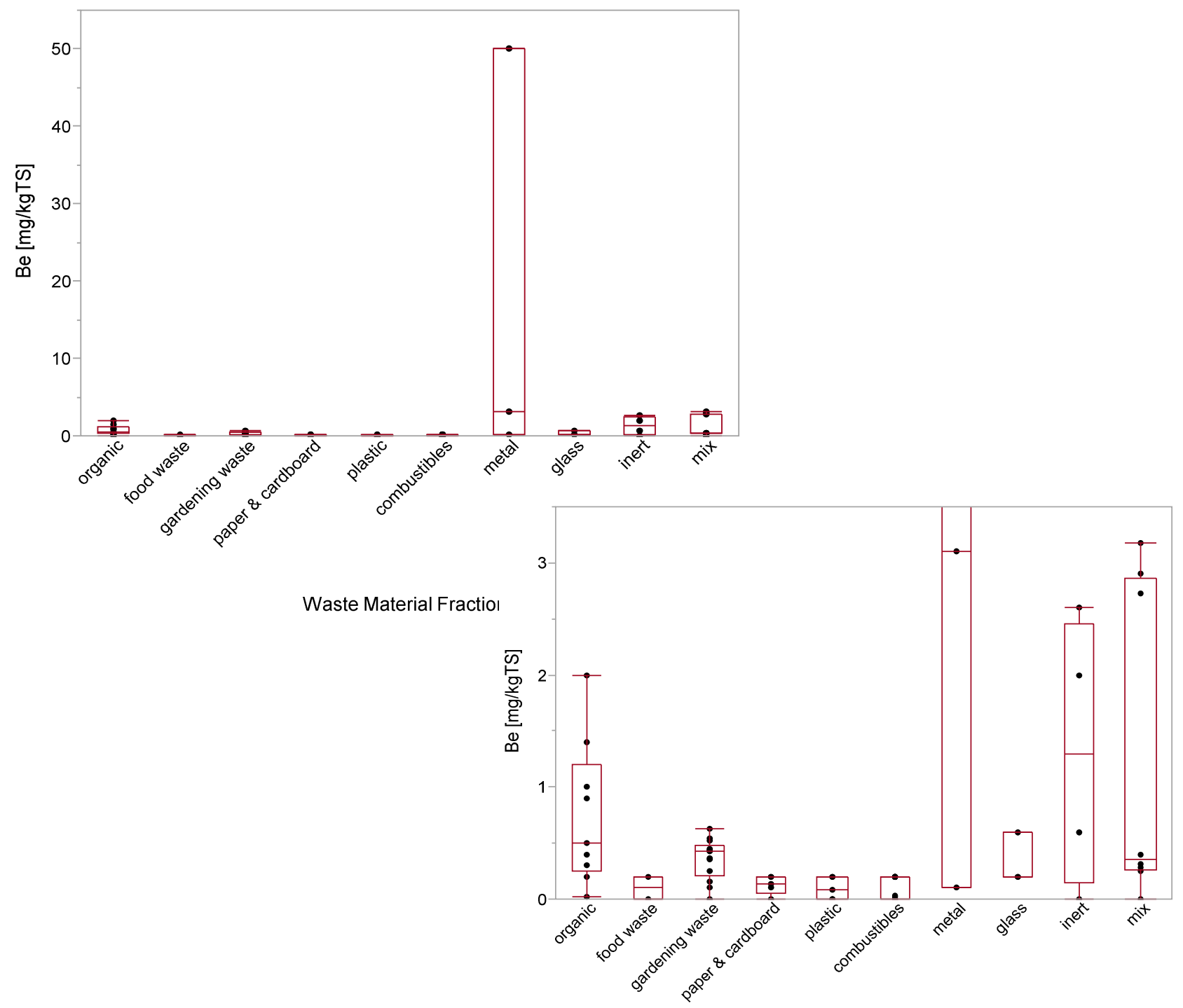

\section{Quantiles [mg/kgTS]}

Waste Material Fractions

\begin{tabular}{|c|c|c|c|c|c|c|c|c|c|}
\hline $\begin{array}{c}\text { Waste Material } \\
\text { Fraction }\end{array}$ & n_data* & $n \_<D L^{* *}$ & Min & $10 \%$ & $25 \%$ & Median & $75 \%$ & $90 \%$ & Max \\
\hline organic & 9 & 1 & 0.02 & 0.02 & 0.25 & 0.50 & 1.20 & 2.00 & 2.00 \\
\hline food waste & 2 & - & 0.00 & 0.00 & 0.00 & 0.10 & 0.20 & 0.20 & 0.20 \\
\hline gardening waste & 13 & - & 0.00 & 0.04 & 0.21 & 0.43 & 0.49 & 0.59 & 0.63 \\
\hline paper \& cardboard & 5 & - & 0.00 & 0.00 & 0.05 & 0.14 & 0.20 & 0.20 & 0.20 \\
\hline composites & - & - & - & - & - & - & - & - & - \\
\hline plastic & 5 & 1 & 0.00 & 0.00 & 0.00 & 0.08 & 0.20 & 0.20 & 0.20 \\
\hline combustibles & 14 & & 0.00 & 0.00 & 0.00 & 0.20 & 0.20 & 0.20 & 0.20 \\
\hline metal & 3 & 1 & 0.10 & 0.10 & 0.10 & 3.10 & 50.00 & 50.00 & 50.00 \\
\hline glass & 3 & - & 0.20 & 0.20 & 0.20 & 0.20 & 0.60 & 0.60 & 0.60 \\
\hline inert & 4 & - & 0.00 & 0.00 & 0.15 & 1.30 & 2.45 & 2.60 & 2.60 \\
\hline $\operatorname{mix}$ & 8 & - & 0.00 & 0.00 & 0.26 & 0.36 & 2.86 & 3.18 & 3.18 \\
\hline
\end{tabular}

*) number of data points

${ }^{* *}$ ) number of values below the detection limit 


\section{Value ranges for $\mathrm{Br}$}

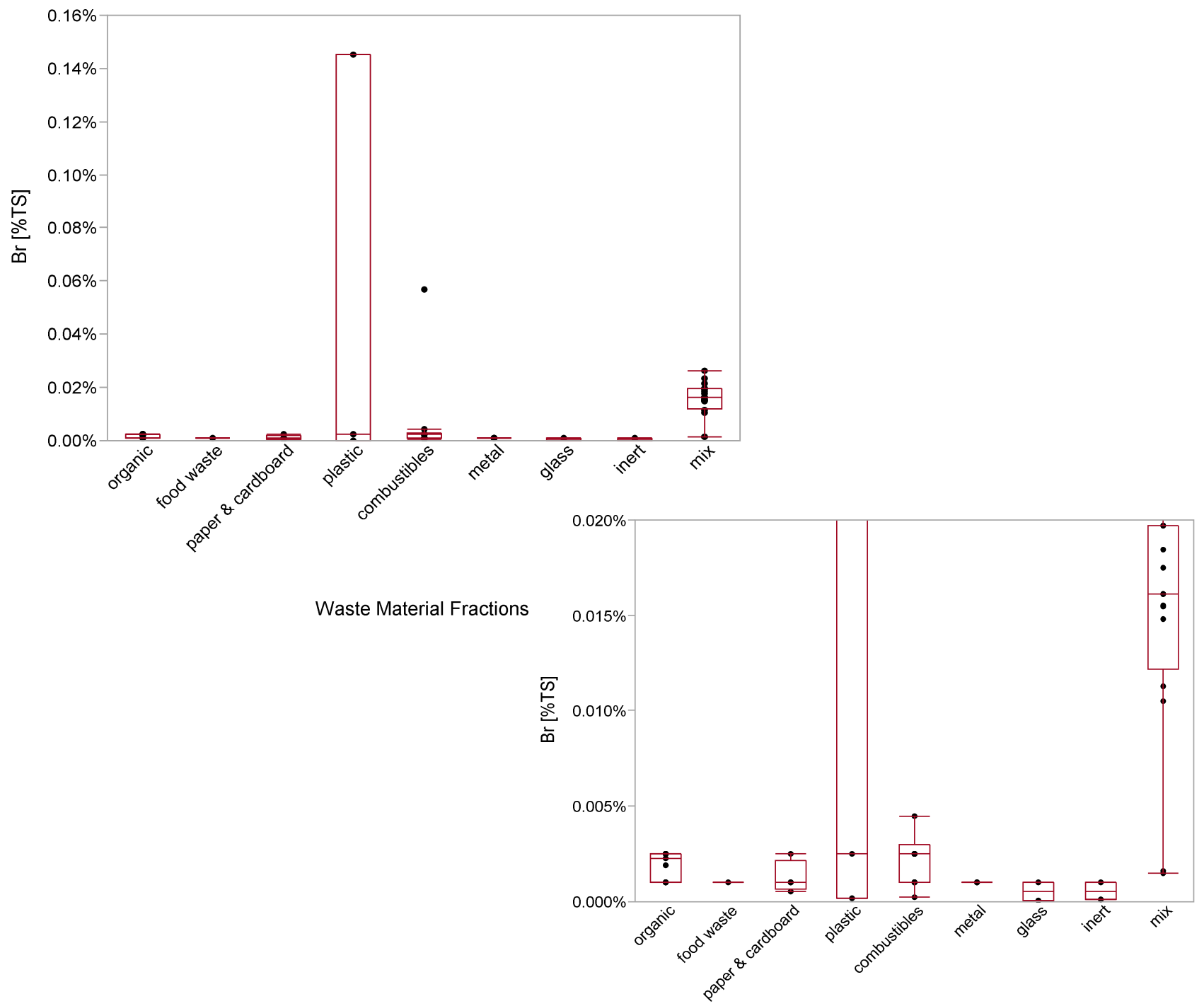

Quantiles [\%TS]

Waste Material Fractions

\section{Waste Material}

\begin{tabular}{|c|c|c|c|c|c|c|c|c|c|}
\hline Fraction & n_data* & $\mathrm{n} \_\mathrm{DL}^{* *}$ & Min & $10 \%$ & $25 \%$ & Median & $75 \%$ & $90 \%$ & Max \\
\hline organic & 9 & 7 & $0.001 \%$ & $0.001 \%$ & $0.001 \%$ & $0.002 \%$ & $0.003 \%$ & $0.003 \%$ & $0.003 \%$ \\
\hline food waste & 1 & 1 & $0.001 \%$ & $0.001 \%$ & $0.001 \%$ & $0.001 \%$ & $0.001 \%$ & $0.001 \%$ & $0.001 \%$ \\
\hline gardening waste & - & - & - & - & - & - & - & - & - \\
\hline paper \& cardboard & 4 & 2 & $0.001 \%$ & $0.001 \%$ & $0.001 \%$ & $0.001 \%$ & $0.002 \%$ & $0.003 \%$ & $0.003 \%$ \\
\hline composites & - & - & - & - & - & - & - & - & - \\
\hline plastic & 3 & 1 & $0.000 \%$ & $0.000 \%$ & $0.000 \%$ & $0.003 \%$ & $0.145 \%$ & $0.145 \%$ & $0.145 \%$ \\
\hline combustibles & 10 & 7 & $0.000 \%$ & $0.000 \%$ & $0.001 \%$ & $0.003 \%$ & $0.003 \%$ & $0.052 \%$ & $0.057 \%$ \\
\hline metal & 2 & 2 & $0.001 \%$ & $0.001 \%$ & $0.001 \%$ & $0.001 \%$ & $0.001 \%$ & $0.001 \%$ & $0.001 \%$ \\
\hline glass & 2 & 2 & $0.000 \%$ & $0.000 \%$ & $0.000 \%$ & $0.001 \%$ & $0.001 \%$ & $0.001 \%$ & $0.001 \%$ \\
\hline inert & 2 & 1 & $0.000 \%$ & $0.000 \%$ & $0.000 \%$ & $0.001 \%$ & $0.001 \%$ & $0.001 \%$ & $0.001 \%$ \\
\hline $\operatorname{mix}$ & 16 & 1 & $0.002 \%$ & $0.002 \%$ & $0.012 \%$ & $0.016 \%$ & $0.020 \%$ & $0.024 \%$ & $0.026 \%$ \\
\hline
\end{tabular}

*) number of data points

${ }^{* *}$ ) number of values below the detection limit 


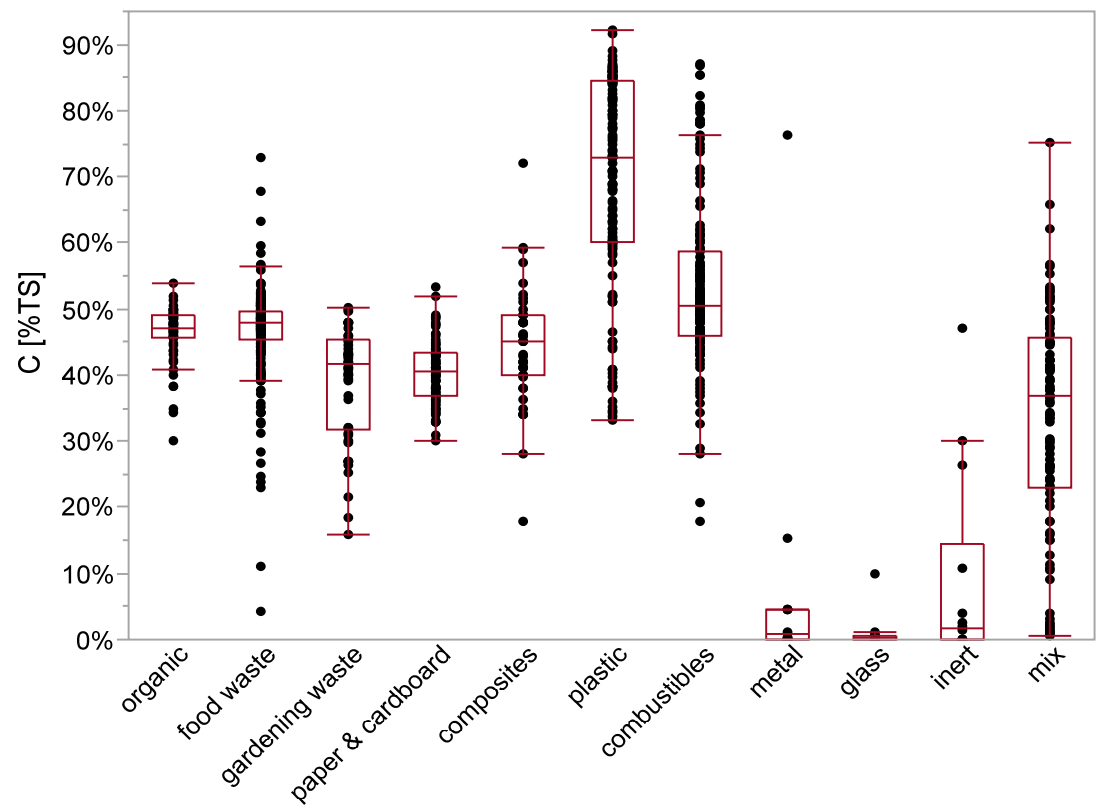

Waste Material Fractions

\section{Quantiles [\%TS]}

\begin{tabular}{|c|c|c|c|c|c|c|c|c|c|}
\hline $\begin{array}{c}\text { Waste Material } \\
\text { Fraction }\end{array}$ & n_data* & $\mathrm{n}_{-}<\mathrm{DL} * *$ & Min & $10 \%$ & $25 \%$ & Median & $75 \%$ & $90 \%$ & Max \\
\hline organic & 61 & - & $30.0 \%$ & $40.2 \%$ & $45.6 \%$ & $47.2 \%$ & $49.0 \%$ & $50.0 \%$ & $54.0 \%$ \\
\hline food waste & 211 & - & $4.4 \%$ & $39.5 \%$ & $45.2 \%$ & $47.9 \%$ & $49.8 \%$ & $51.6 \%$ & $73.0 \%$ \\
\hline gardening waste & 49 & - & $15.8 \%$ & $26.5 \%$ & $31.7 \%$ & $41.8 \%$ & $45.5 \%$ & $47.8 \%$ & $50.1 \%$ \\
\hline paper \& cardboard & 113 & - & $30.2 \%$ & $34.4 \%$ & $37.0 \%$ & $40.5 \%$ & $43.3 \%$ & $46.2 \%$ & $53.4 \%$ \\
\hline composites & 42 & - & $18.0 \%$ & $34.0 \%$ & $39.9 \%$ & $45.0 \%$ & $49.0 \%$ & $56.1 \%$ & $72.0 \%$ \\
\hline plastic & 137 & - & $33.3 \%$ & $40.7 \%$ & $60.0 \%$ & $73.0 \%$ & $84.5 \%$ & $86.1 \%$ & $92.1 \%$ \\
\hline combustibles & 152 & - & $18.0 \%$ & $42.6 \%$ & $46.1 \%$ & $50.5 \%$ & $58.6 \%$ & $76.2 \%$ & $87.1 \%$ \\
\hline metal & 14 & - & $0.0 \%$ & $0.0 \%$ & $0.0 \%$ & $0.8 \%$ & $4.5 \%$ & $45.7 \%$ & $76.2 \%$ \\
\hline glass & 14 & - & $0.0 \%$ & $0.0 \%$ & $0.0 \%$ & $0.4 \%$ & $0.5 \%$ & $5.5 \%$ & $9.8 \%$ \\
\hline inert & 14 & - & $0.0 \%$ & $0.0 \%$ & $0.0 \%$ & $1.6 \%$ & $14.6 \%$ & $38.6 \%$ & $47.1 \%$ \\
\hline $\operatorname{mix}$ & 104 & - & $0.6 \%$ & $3.5 \%$ & $23.0 \%$ & $36.8 \%$ & $45.8 \%$ & $52.2 \%$ & $75.2 \%$ \\
\hline
\end{tabular}

Grand Total

911

$\left.{ }^{*}\right)$ number of data points

$\left.{ }^{\star *}\right)$ number of values below the detection limit 


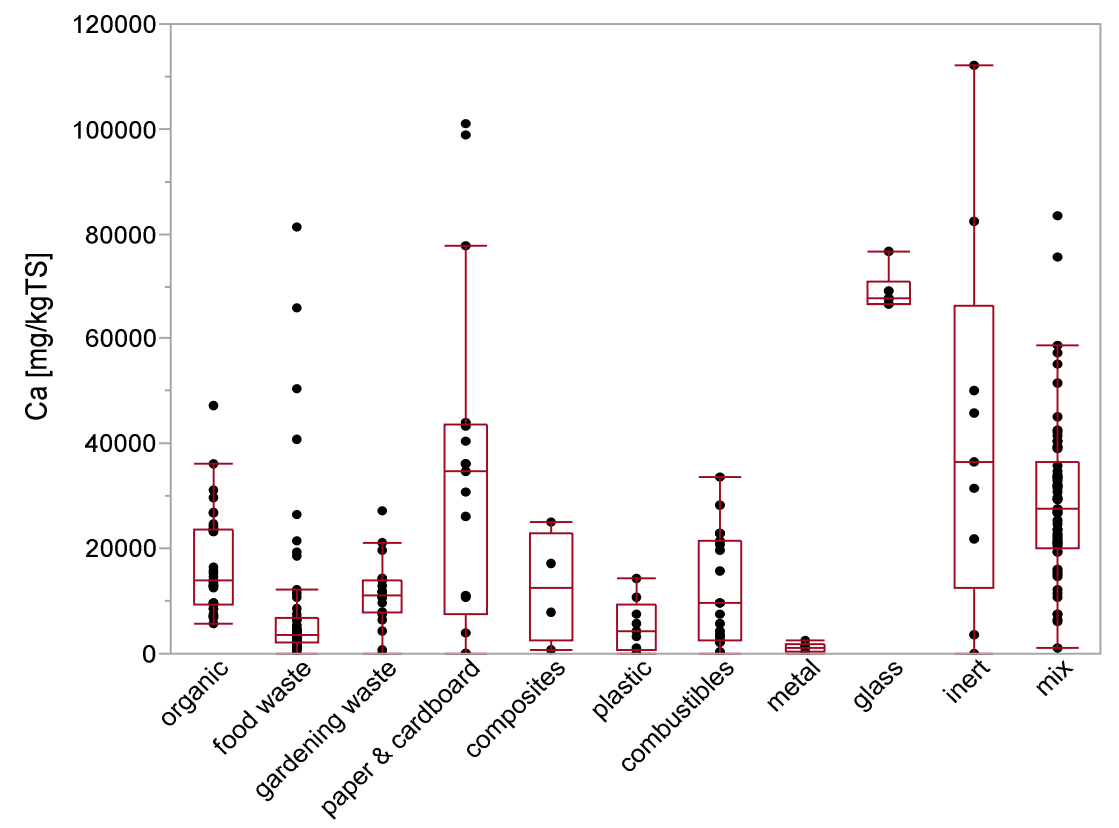

Waste Material Fractions

\section{Quantiles [mg/kgTS]}

\section{Waste Material}

\begin{tabular}{|c|c|c|c|c|c|c|c|c|c|}
\hline Fraction & n_data* & $\mathbf{n} \_<L^{* *}$ & Min & $10 \%$ & $25 \%$ & Median & $75 \%$ & $90 \%$ & Max \\
\hline organic & 38 & - & 5700 & 7180 & 9475 & 14000 & 23750 & 29850 & 47313 \\
\hline food waste & 57 & - & 0 & 1156 & 1977 & 3611 & 6709 & 22553 & 81250 \\
\hline gardening waste & 21 & - & 0 & 1306 & 7750 & 11256 & 14149 & 20838 & 27100 \\
\hline paper \& cardboard & 17 & - & 0 & 0 & 7415 & 34600 & 43600 & 99160 & 101000 \\
\hline composites & 4 & - & 727 & 727 & 2500 & 12555 & 23080 & 25010 & 25010 \\
\hline plastic & 9 & - & 21.5 & 22 & 577 & 4160 & 9270 & 14260 & 14260 \\
\hline combustibles & 23 & - & 45.7 & 51 & 2390 & 9510 & 21522 & 26140 & 33770 \\
\hline metal & 6 & - & 36 & 36 & 192 & 1143 & 1728 & 2410 & 2410 \\
\hline glass & 6 & - & 66730 & 66730 & 66783 & 67775 & 70900 & 76600 & 76600 \\
\hline inert & 9 & - & 0 & 0 & 12675 & 36400 & 66303 & 112110 & 112110 \\
\hline $\operatorname{mix}$ & 62 & - & 1228.6 & 10950 & 20075 & 27500 & 36675 & 49640 & 83550 \\
\hline
\end{tabular}

*) number of data points

$\left.{ }^{* *}\right)$ number of values below the detection limit 
Value ranges for $\mathrm{Cd}$

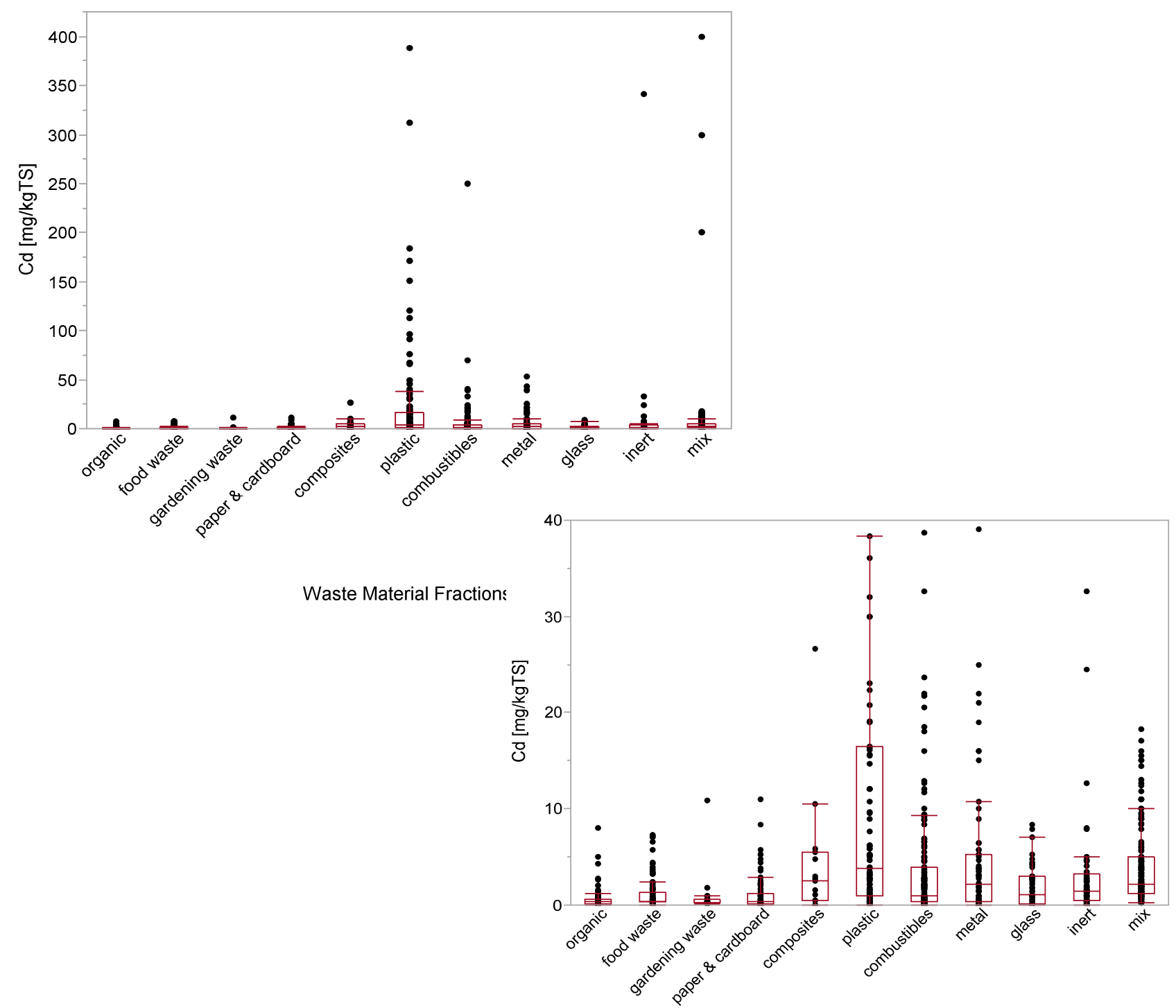

\section{Quantiles [mg/kgTS]}

\begin{tabular}{|c|c|c|c|c|c|c|c|c|c|}
\hline \multirow{2}{*}{$\begin{array}{l}\text { Waste Material } \\
\text { Fraction }\end{array}$} & \multirow[b]{2}{*}{ n_data* } & \multirow[b]{2}{*}{$\mathrm{n}_{-}<\mathrm{DL} * *$} & \multirow[b]{2}{*}{ Min } & \multicolumn{6}{|c|}{ Waste Material Fractions } \\
\hline & & & & $10 \%$ & $25 \%$ & Median & $75 \%$ & $90 \%$ & Max \\
\hline organic & 71 & 5 & 0.00 & 0.08 & 0.15 & 0.35 & 0.60 & 1.56 & 7.95 \\
\hline food waste & 100 & 42 & 0.00 & 0.10 & 0.40 & 0.40 & 1.28 & 3.49 & 7.30 \\
\hline gardening waste & 23 & - & 0.11 & 0.16 & 0.20 & 0.25 & 0.60 & 1.48 & 10.85 \\
\hline paper \& cardboard & 88 & 4 & 0.00 & 0.00 & 0.09 & 0.30 & 1.25 & 3.62 & 11.00 \\
\hline composites & 15 & - & 0.00 & 0.01 & 0.50 & 2.52 & 5.50 & 16.94 & 26.60 \\
\hline plastic & 103 & 2 & 0.00 & 0.20 & 0.90 & 3.80 & 16.50 & 72.68 & 388.00 \\
\hline combustibles & 158 & 3 & 0.00 & 0.00 & 0.30 & 1.00 & 3.93 & 11.73 & 250.00 \\
\hline metal & 71 & 5 & 0.00 & 0.00 & 0.30 & 2.10 & 5.20 & 18.40 & 53.00 \\
\hline glass & 49 & 4 & 0.00 & 0.00 & 0.15 & 1.10 & 2.95 & 4.80 & 8.40 \\
\hline inert & 50 & - & 0.00 & 0.00 & 0.50 & 1.45 & 3.28 & 7.99 & 341.00 \\
\hline $\operatorname{mix}$ & 141 & - & 0.20 & 0.76 & 1.25 & 2.17 & 5.04 & 11.67 & 400.00 \\
\hline Grand Total & 869 & 65 & & & & & & & \\
\hline
\end{tabular}


Value ranges for $\mathrm{Cl}$

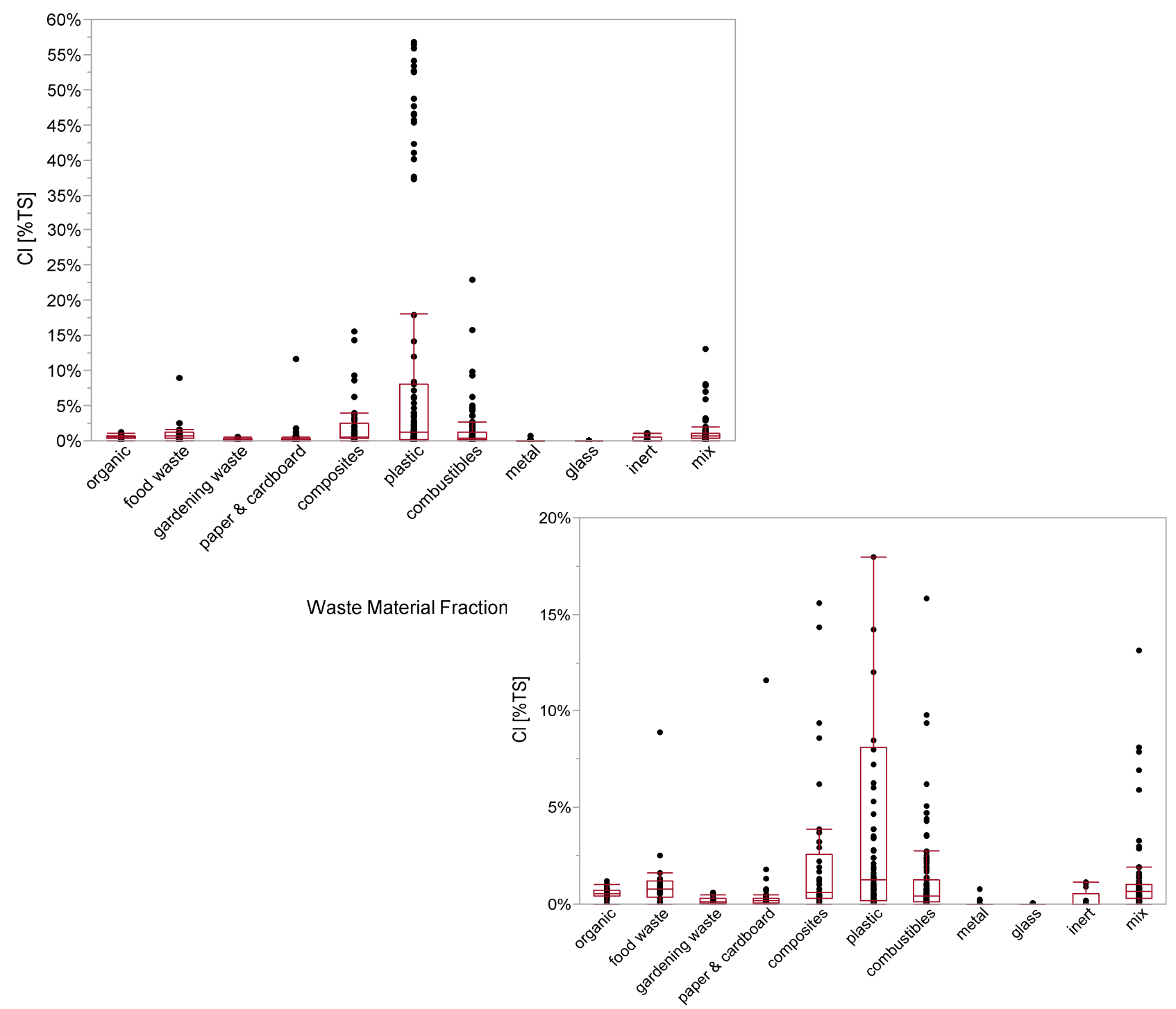

\section{Quantiles [\%TS]}

Waste Material Fractions

\section{Waste Material}

\begin{tabular}{lrrrrrrrrr}
\multicolumn{1}{c}{ Fraction } & n_data* $^{*}$ & $\mathbf{n}_{\mathbf{C}}<\mathbf{D L}^{* *}$ & Min & $\mathbf{1 0 \%}$ & $\mathbf{2 5 \%}$ & Median & $\mathbf{7 5 \%}$ & $\mathbf{9 0 \%}$ & $\mathbf{M a x}$ \\
\hline organic & 58 & - & $0.001 \%$ & $0.165 \%$ & $0.400 \%$ & $0.532 \%$ & $0.700 \%$ & $0.806 \%$ & $1.200 \%$ \\
food waste & 20 & - & $0.000 \%$ & $0.012 \%$ & $0.365 \%$ & $0.765 \%$ & $1.173 \%$ & $2.413 \%$ & $8.900 \%$ \\
gardening waste & 26 & - & $0.000 \%$ & $0.047 \%$ & $0.078 \%$ & $0.110 \%$ & $0.283 \%$ & $0.530 \%$ & $0.600 \%$ \\
paper \& cardboard & 75 & - & $0.000 \%$ & $0.001 \%$ & $0.070 \%$ & $0.160 \%$ & $0.300 \%$ & $0.500 \%$ & $11.600 \%$ \\
composites & 41 & - & $0.000 \%$ & $0.000 \%$ & $0.300 \%$ & $0.600 \%$ & $2.550 \%$ & $8.120 \%$ & $15.600 \%$ \\
plastic & 90 & - & $0.000 \%$ & $0.000 \%$ & $0.200 \%$ & $1.250 \%$ & $8.125 \%$ & $47.605 \%$ & $56.800 \%$ \\
combustibles & 114 & - & $0.000 \%$ & $0.000 \%$ & $0.100 \%$ & $0.400 \%$ & $1.248 \%$ & $3.550 \%$ & $23.000 \%$ \\
metal & 19 & - & $0.000 \%$ & $0.000 \%$ & $0.000 \%$ & $0.000 \%$ & $0.001 \%$ & $0.240 \%$ & $0.760 \%$ \\
glass & 10 & - & $0.000 \%$ & $0.000 \%$ & $0.000 \%$ & $0.000 \%$ & $0.000 \%$ & $0.054 \%$ & $0.060 \%$ \\
inert & 13 & - & $0.000 \%$ & $0.000 \%$ & $0.000 \%$ & $0.020 \%$ & $0.550 \%$ & $1.094 \%$ & $1.110 \%$ \\
mix & 81 & - & $0.000 \%$ & $0.104 \%$ & $0.305 \%$ & $0.670 \%$ & $1.000 \%$ & $2.692 \%$ & $13.160 \%$ \\
\hline Total & 547 & 0 & & & & & & &
\end{tabular}

*) number of data points

$\left.{ }^{\star *}\right)$ number of values below the detection limit 
Value ranges for Co

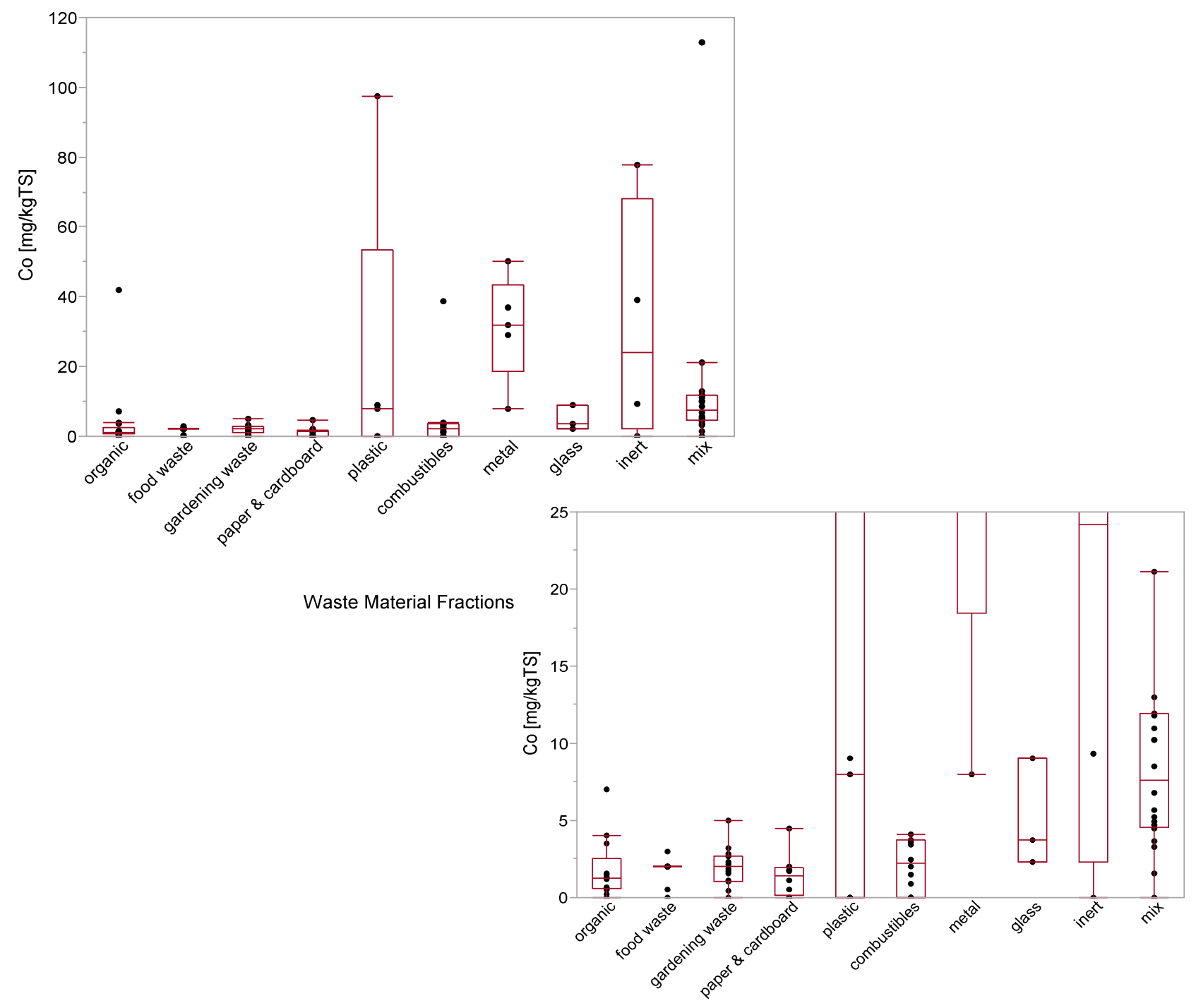

Quantiles [mg/kgTS]

Waste Material Fractions

\begin{tabular}{|c|c|c|c|c|c|c|c|c|c|}
\hline $\begin{array}{l}\text { Waste Material } \\
\text { Fraction }\end{array}$ & n_data* & $n \_<L^{* *}$ & Min & $10 \%$ & $25 \%$ & Median & $75 \%$ & $90 \%$ & Max \\
\hline organic & 17 & 1 & 0.0 & 0.2 & 0.6 & 1.3 & 2.6 & 14.0 & 42.0 \\
\hline food waste & 43 & 41 & 0.0 & 2.0 & 2.0 & 2.0 & 2.0 & 2.0 & 3.0 \\
\hline gardening waste & 14 & - & 0.0 & 0.2 & 1.1 & 2.0 & 2.7 & 4.1 & 5.0 \\
\hline paper \& cardboard & 8 & 1 & 0.0 & 0.0 & 0.1 & 1.4 & 2.0 & 4.5 & 4.5 \\
\hline composites & - & - & - & - & - & - & - & - & - \\
\hline plastic & 5 & - & 0.0 & 0.0 & 0.0 & 8.0 & 53.3 & 97.6 & 97.6 \\
\hline combustibles & 14 & - & 0.0 & 0.0 & 0.0 & 2.3 & 3.7 & 21.4 & 38.7 \\
\hline metal & 5 & - & 8.0 & 8.0 & 18.5 & 32.0 & 43.5 & 50.0 & 50.0 \\
\hline glass & 3 & - & 2.3 & 2.3 & 2.3 & 3.7 & 9.0 & 9.0 & 9.0 \\
\hline inert & 4 & - & 0.0 & 0.0 & 2.3 & 24.2 & 68.0 & 77.7 & 77.7 \\
\hline $\operatorname{mix}$ & 20 & - & 0.0 & 1.8 & 4.5 & 7.6 & 11.9 & 103.8 & 113.0 \\
\hline
\end{tabular}

*) number of data points

${ }^{* *}$ ) number of values below the detection limit 


\section{Value ranges for $\mathrm{Cr}$}

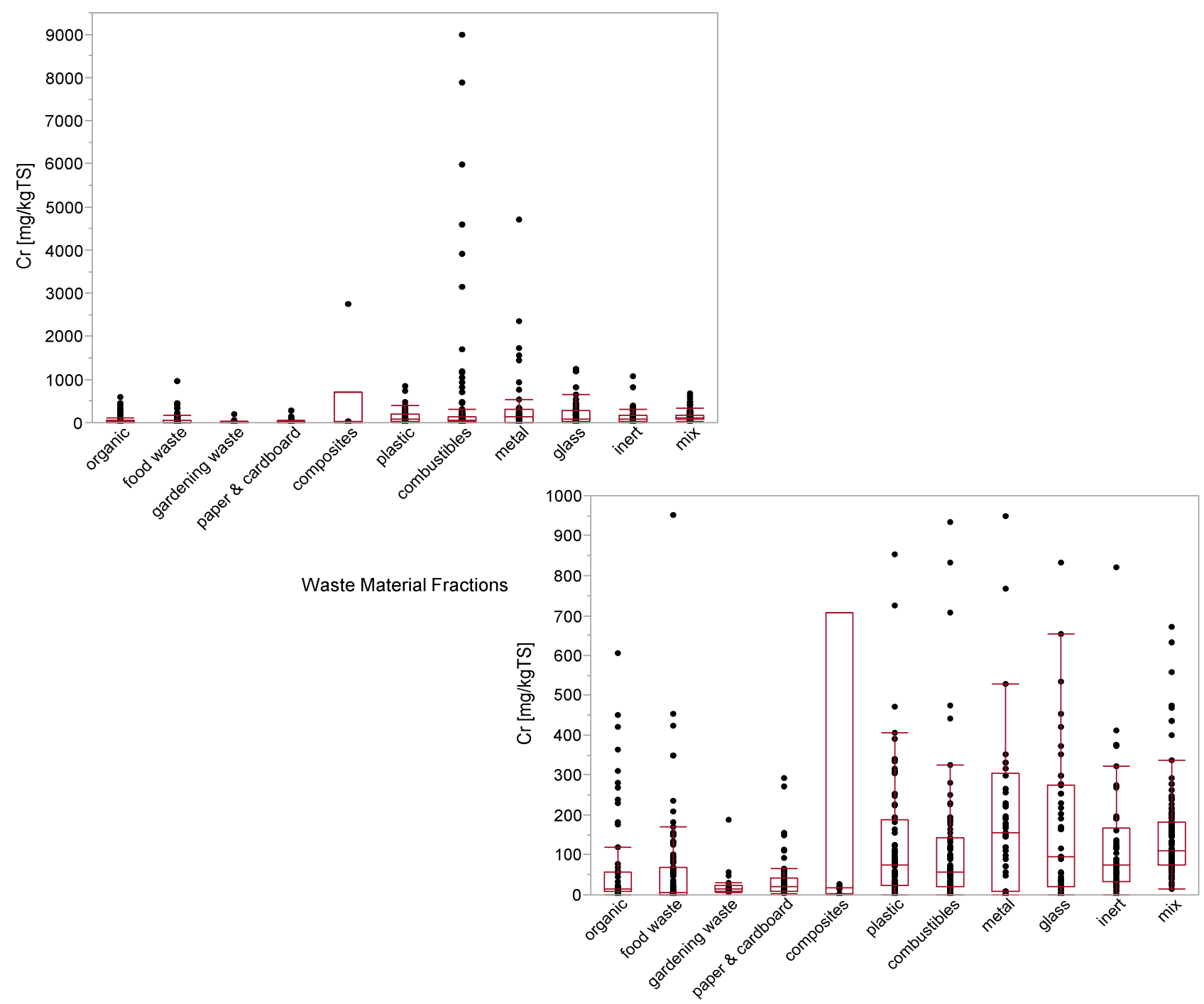

\section{Quantiles [mg/kgTS]}

Waste Material Fractions

\begin{tabular}{|c|c|c|c|c|c|c|c|c|c|}
\hline $\begin{array}{c}\text { Waste Material } \\
\text { Fraction }\end{array}$ & n_data* & $n_{-}<D L^{* *}$ & Min & $10 \%$ & $25 \%$ & Median & $75 \%$ & $90 \%$ & Max \\
\hline organic & 62 & - & 1.3 & 6.2 & 8.4 & 14.8 & 56.3 & 277.0 & 607.0 \\
\hline food waste & 103 & 17 & 0.0 & 1.0 & 1.1 & 5.2 & 69.0 & 155.3 & 951.5 \\
\hline gardening waste & 19 & 1 & 4.5 & 8.0 & 8.7 & 16.2 & 23.0 & 55.5 & 188.7 \\
\hline paper \& cardboard & 65 & - & 2.5 & 5.4 & 8.8 & 20.0 & 40.3 & 99.4 & 291.8 \\
\hline composites & 6 & - & 1.0 & 1.0 & 2.4 & 18.5 & 708.5 & 2750.0 & 2750.0 \\
\hline plastic & 73 & - & 0.4 & 9.7 & 25.4 & 73.9 & 187.0 & 338.4 & 853.0 \\
\hline combustibles & 122 & - & 0.0 & 6.2 & 19.8 & 56.4 & 142.2 & 795.3 & 9000.0 \\
\hline metal & 50 & - & 0.0 & 0.0 & 9.2 & 154.5 & 304.3 & 1387.0 & 4702.0 \\
\hline glass & 49 & - & 0.0 & 0.0 & 21.6 & 95.3 & 275.7 & 534.0 & 1236.8 \\
\hline inert & 50 & - & 0.0 & 13.4 & 34.0 & 74.3 & 167.5 & 377.1 & 1075.5 \\
\hline $\operatorname{mix}$ & 116 & - & 16.0 & 53.0 & 74.8 & 111.8 & 182.3 & 277.1 & 671.1 \\
\hline
\end{tabular}

\begin{tabular}{lll}
\hline Grand Total & 715 & 18
\end{tabular}

*) number of data points

${ }^{* *}$ ) number of values below the detection limit 


\section{Value ranges for $\mathrm{Cu}$}

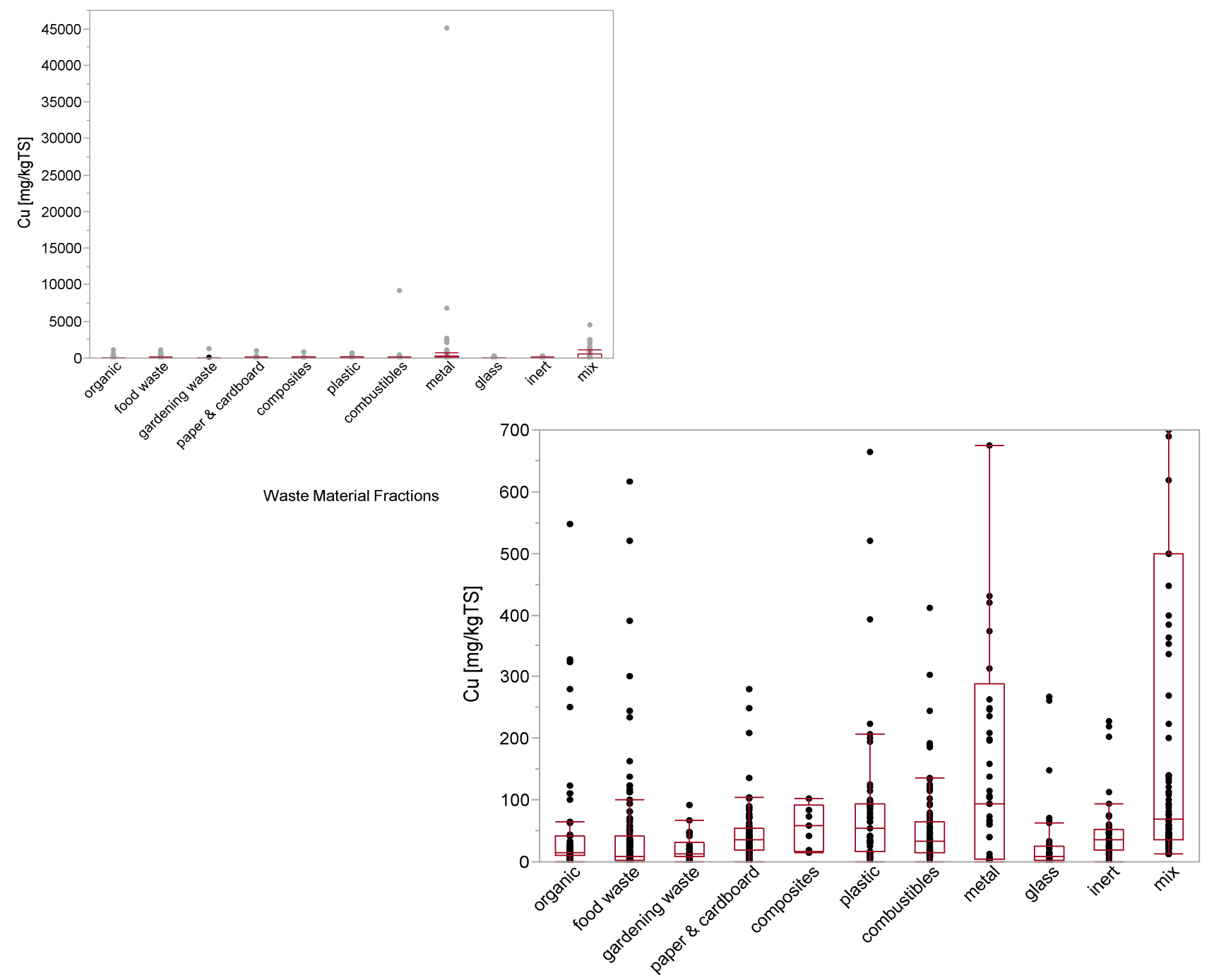

\section{Quantiles [mg/kgTS]}

Waste Material Fractions

\begin{tabular}{|c|c|c|c|c|c|c|c|c|c|}
\hline $\begin{array}{l}\text { Waste Material } \\
\text { Fraction }\end{array}$ & n_data* & $\mathrm{n}_{-}<\mathrm{DL} * *$ & Min & $10 \%$ & $25 \%$ & Median & $75 \%$ & $90 \%$ & Max \\
\hline organic & 59 & - & 0.00 & 7.22 & 10.20 & 15.10 & 41.45 & 250.00 & 1196.59 \\
\hline food waste & 117 & 40 & 0.00 & 2.00 & 2.00 & 9.00 & 42.00 & 126.82 & 1168.20 \\
\hline gardening waste & 30 & - & 0.18 & 0.60 & 7.93 & 13.11 & 31.25 & 64.30 & 1238.61 \\
\hline paper \& cardboard & 72 & - & 0.00 & 7.86 & 17.78 & 34.76 & 55.20 & 98.49 & 1019.60 \\
\hline composites & 9 & - & 14.00 & 14.00 & 17.05 & 59.40 & 92.55 & 834.00 & 834.00 \\
\hline plastic & 57 & - & 0.00 & 8.24 & 16.85 & 54.20 & 93.85 & 201.20 & 665.30 \\
\hline combustibles & 112 & - & 0.00 & 8.79 & 14.35 & 33.60 & 65.35 & 131.93 & 9240.00 \\
\hline metal & 53 & 1 & 0.00 & 0.00 & 4.55 & 94.50 & 288.60 & 1691.20 & 45100.00 \\
\hline glass & 42 & - & 0.00 & 0.00 & 1.85 & 8.50 & 26.00 & 69.64 & 267.50 \\
\hline inert & 46 & - & 0.00 & 0.56 & 18.58 & 35.80 & 51.70 & 99.70 & 227.00 \\
\hline $\operatorname{mix}$ & 110 & - & 12.17 & 19.61 & 35.21 & 67.93 & 500.00 & 1154.99 & 4500.00 \\
\hline Grand Total & 707 & 41 & & & & & & & \\
\hline
\end{tabular}

*) number of data points

${ }^{* *}$ ) number of values below the detection limit 
Value ranges for $F$

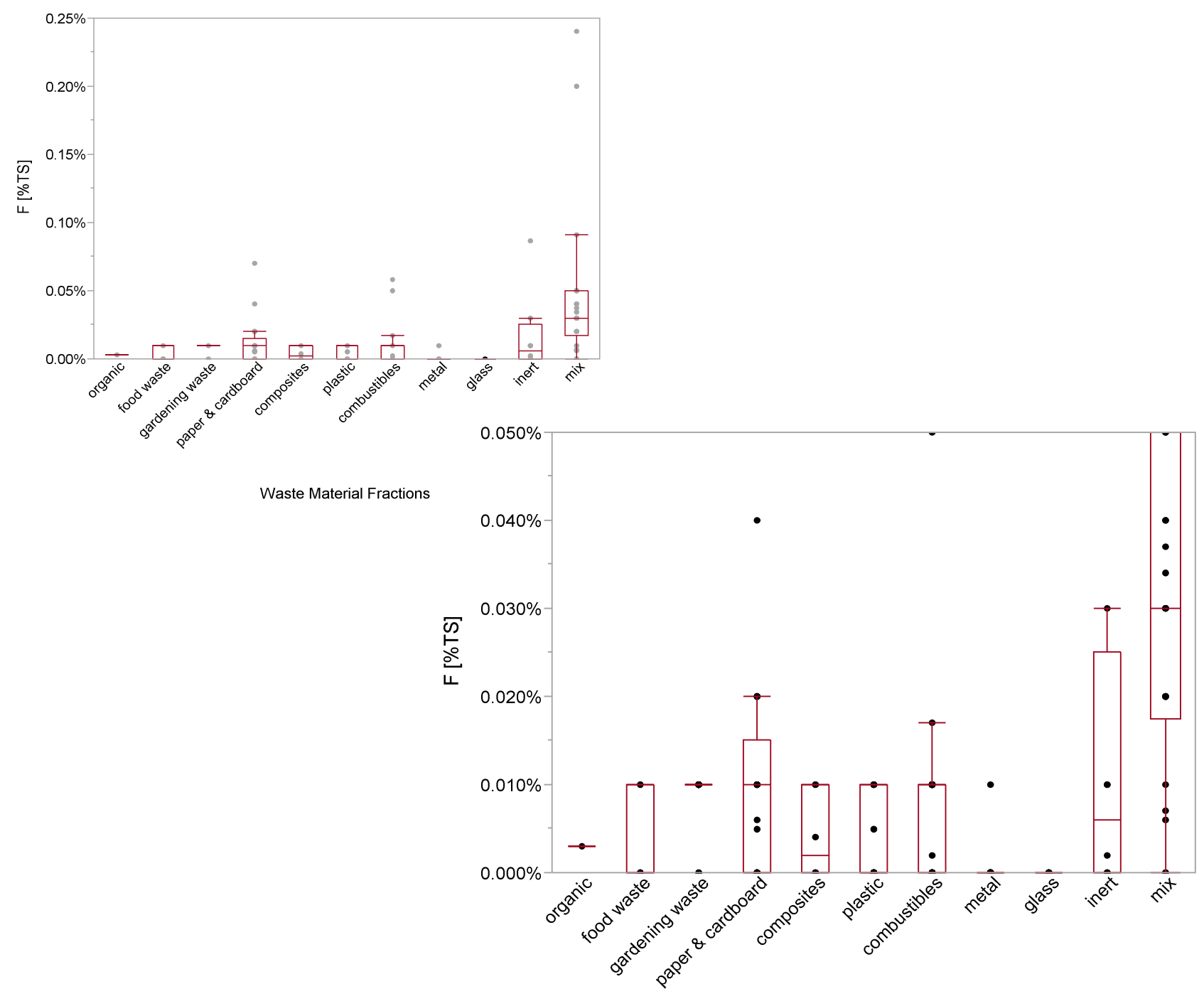

Quantiles [\%TS]

Waste Material Fractions

Waste Material

\begin{tabular}{lrrrrrrrrr}
\multicolumn{1}{c}{ Fraction } & $\mathbf{n}$ data*$^{*}$ & $\mathbf{n}<$ DL** $^{*}$ & Min & $\mathbf{1 0 \%}$ & $\mathbf{2 5 \%}$ & Median & $\mathbf{7 5 \%}$ & $\mathbf{9 0 \%}$ & $\mathbf{M a x}$ \\
\hline organic & - & - & - & - & - & - & - & - & - \\
food waste & 5 & - & $0.000 \%$ & $0.000 \%$ & $0.000 \%$ & $0.000 \%$ & $0.010 \%$ & $0.010 \%$ & $0.010 \%$ \\
gardening waste & 16 & 12 & $0.000 \%$ & $0.000 \%$ & $0.010 \%$ & $0.010 \%$ & $0.010 \%$ & $0.010 \%$ & $0.010 \%$ \\
paper \& cardboard & 21 & - & $0.000 \%$ & $0.000 \%$ & $0.000 \%$ & $0.010 \%$ & $0.015 \%$ & $0.036 \%$ & $0.070 \%$ \\
composites & 6 & - & $0.000 \%$ & $0.000 \%$ & $0.000 \%$ & $0.002 \%$ & $0.010 \%$ & $0.010 \%$ & $0.010 \%$ \\
plastic & 14 & - & $0.000 \%$ & $0.000 \%$ & $0.000 \%$ & $0.000 \%$ & $0.010 \%$ & $0.010 \%$ & $0.010 \%$ \\
combustibles & 25 & - & $0.000 \%$ & $0.000 \%$ & $0.000 \%$ & $0.010 \%$ & $0.010 \%$ & $0.030 \%$ & $0.058 \%$ \\
metal & 17 & - & $0.000 \%$ & $0.000 \%$ & $0.000 \%$ & $0.000 \%$ & $0.000 \%$ & $0.002 \%$ & $0.010 \%$ \\
glass & 6 & - & $0.000 \%$ & $0.000 \%$ & $0.000 \%$ & $0.000 \%$ & $0.000 \%$ & $0.000 \%$ & $0.000 \%$ \\
inert & 8 & - & $0.000 \%$ & $0.000 \%$ & $0.000 \%$ & $0.006 \%$ & $0.025 \%$ & $0.087 \%$ & $0.087 \%$ \\
mix & 22 & - & $0.000 \%$ & $0.002 \%$ & $0.018 \%$ & $0.030 \%$ & $0.050 \%$ & $0.200 \%$ & $0.240 \%$ \\
\hline Total & 140 & 12 & & & & & & &
\end{tabular}

$\left.{ }^{*}\right)$ number of data points

$\left.{ }^{\star *}\right)$ number of values below the detection limit 


\section{Value ranges for $\mathrm{Fe}$}

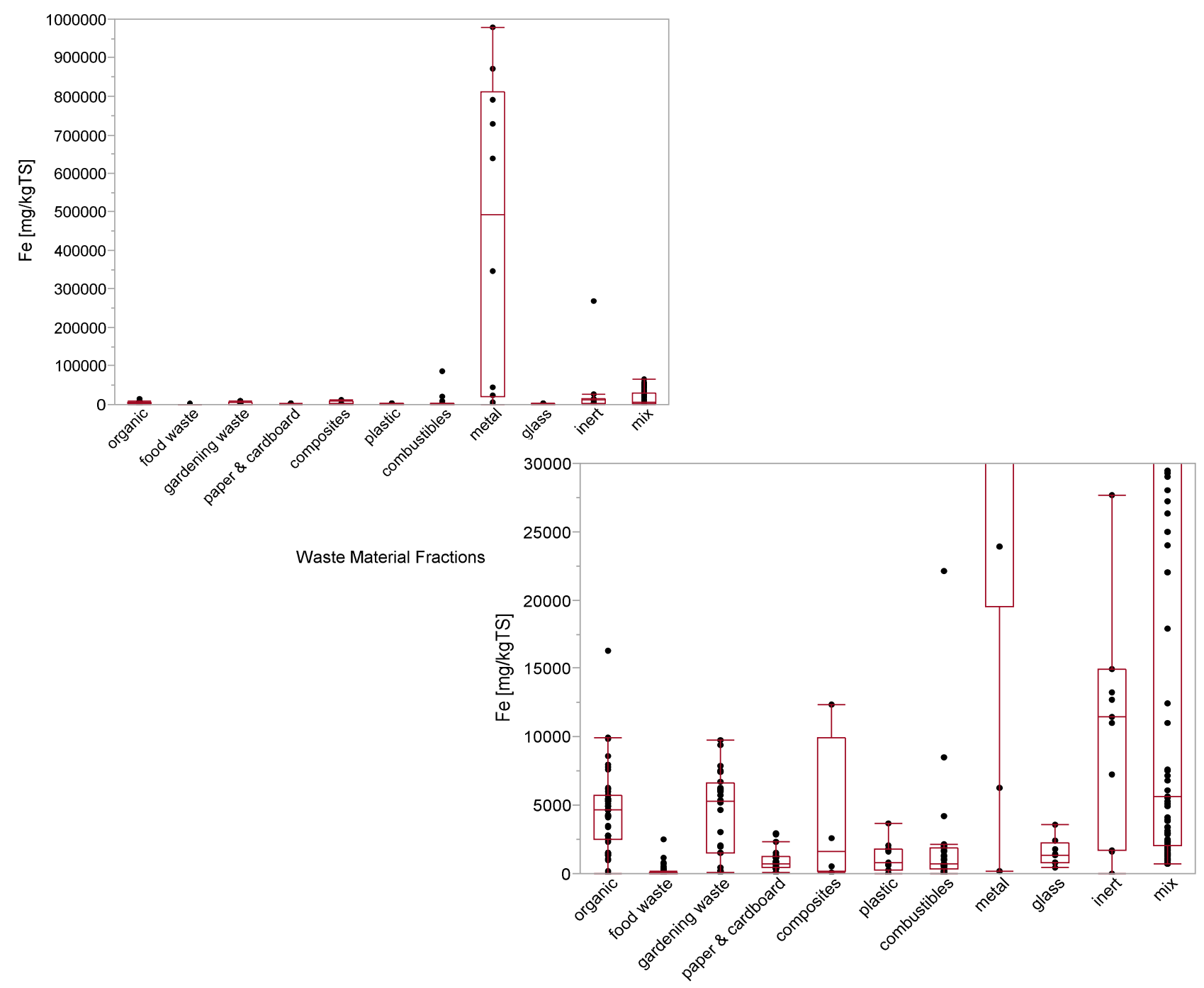

\section{Quantiles [mg/kgTS]}

Waste Material Fractions

\begin{tabular}{|c|c|c|c|c|c|c|c|c|c|}
\hline $\begin{array}{l}\text { Waste Material } \\
\text { Fraction }\end{array}$ & n_data* & $n \_<L^{* *}$ & Min & $10 \%$ & $25 \%$ & Median & $75 \%$ & $90 \%$ & Max \\
\hline organic & 45 & - & 0 & 1220 & 2500 & 4700 & 5700 & 8240 & 16333 \\
\hline food waste & 64 & - & 0 & 18 & 29 & 48 & 88 & 409 & 2478 \\
\hline gardening waste & 24 & - & 76 & 168 & 1485 & 5270 & 6600 & 8643 & 9728 \\
\hline paper \& cardboard & 22 & - & 46 & 147 & 459 & 755 & 1245 & 2722 & 2940 \\
\hline composites & 4 & - & 86 & 86 & 199 & 1585 & 9898 & 12320 & 12320 \\
\hline plastic & 11 & - & 0 & 0 & 305 & 849 & 1830 & 3380 & 3700 \\
\hline combustibles & 31 & - & 0 & 9 & 340 & 733 & 1850 & 7634 & 85100 \\
\hline metal & 10 & - & 150 & 765 & 19500 & 492500 & 810750 & 969300 & 980000 \\
\hline glass & 8 & - & 477 & 477 & 777 & 1350 & 2240 & 3567 & 3567 \\
\hline inert & 11 & - & 0 & 320 & 1730 & 11500 & 14990 & 219940 & 268000 \\
\hline $\operatorname{mix}$ & 82 & - & 684 & 1299 & 2017 & 5605 & 30819 & 49137 & 66000 \\
\hline
\end{tabular}

*) number of data points

${ }^{\star *}$ ) number of values below the detection limit 


\section{Value ranges for $\mathrm{H}$}

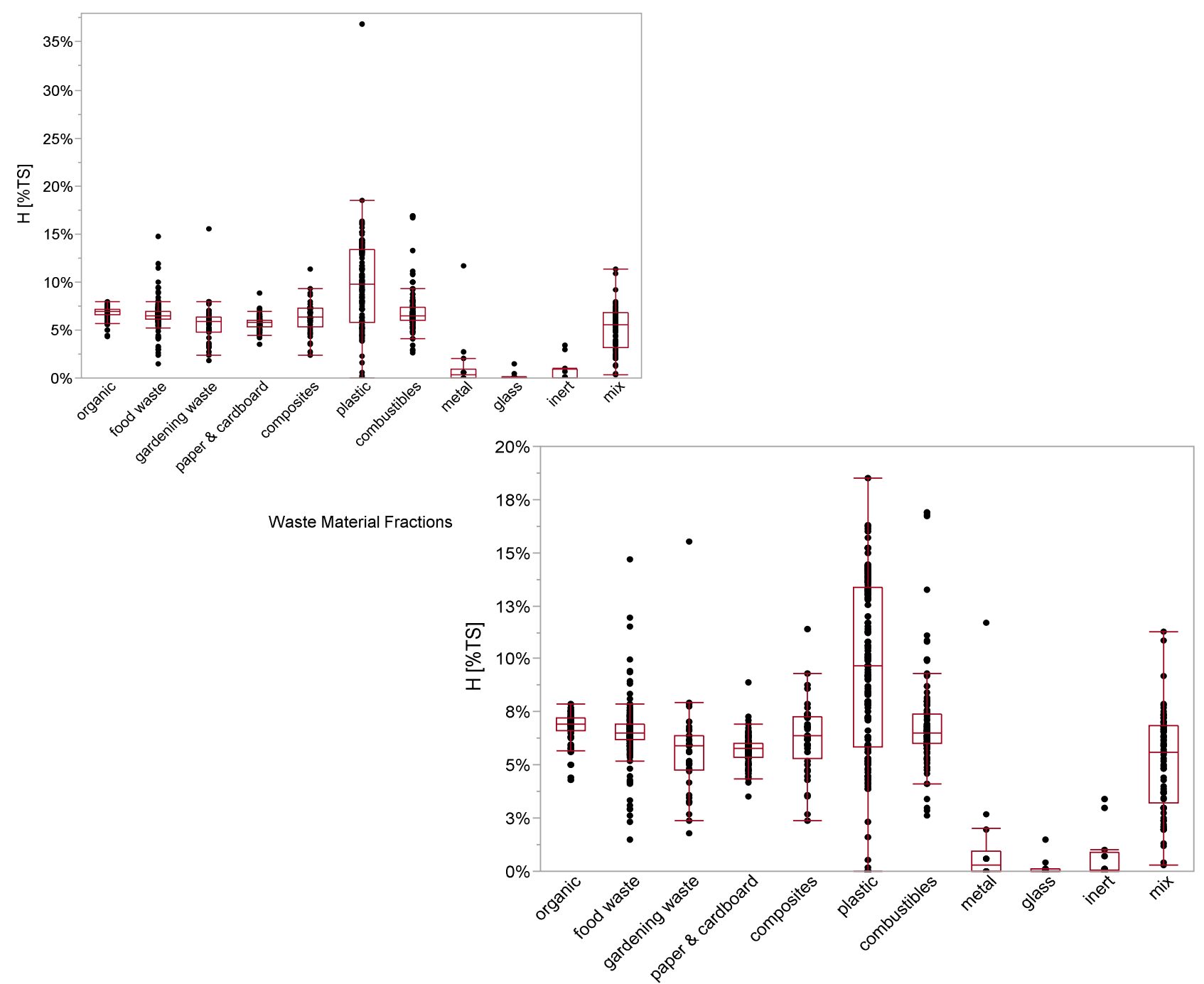

Quantiles [\%TS]

Waste Material Fractions

Waste Material

\begin{tabular}{lrrrrrrrrr}
\multicolumn{1}{c}{ Fraction } & $\mathbf{n} \mathbf{d a t a}^{*}$ & $\mathbf{n}<\mathbf{D L}^{* *}$ & \multicolumn{1}{c}{ Min } & $\mathbf{1 0} \%$ & $\mathbf{2 5 \%}$ & Median & $\mathbf{7 5 \%}$ & \multicolumn{9}{c}{$\mathbf{9 0 \%}$} & \multicolumn{1}{c}{ Max } \\
\hline organic & 59 & - & $4.3 \%$ & $5.7 \%$ & $6.6 \%$ & $6.9 \%$ & $7.2 \%$ & $7.5 \%$ & $7.9 \%$ \\
food waste & 173 & - & $1.5 \%$ & $5.5 \%$ & $6.2 \%$ & $6.5 \%$ & $6.9 \%$ & $7.6 \%$ & $14.7 \%$ \\
gardening waste & 40 & - & $1.8 \%$ & $3.2 \%$ & $4.8 \%$ & $5.9 \%$ & $6.4 \%$ & $7.7 \%$ & $15.5 \%$ \\
paper \& cardboard & 112 & - & $3.5 \%$ & $4.8 \%$ & $5.4 \%$ & $5.8 \%$ & $6.0 \%$ & $6.4 \%$ & $8.9 \%$ \\
composites & 40 & - & $2.4 \%$ & $3.7 \%$ & $5.3 \%$ & $6.4 \%$ & $7.3 \%$ & $8.5 \%$ & $11.4 \%$ \\
plastic & 151 & - & $0.0 \%$ & $3.9 \%$ & $5.8 \%$ & $9.7 \%$ & $13.4 \%$ & $14.4 \%$ & $36.9 \%$ \\
combustibles & 138 & - & $2.6 \%$ & $5.3 \%$ & $6.0 \%$ & $6.5 \%$ & $7.4 \%$ & $9.3 \%$ & $16.9 \%$ \\
metal & 14 & - & $0.0 \%$ & $0.0 \%$ & $0.0 \%$ & $0.3 \%$ & $1.0 \%$ & $7.2 \%$ & $11.7 \%$ \\
glass & 13 & 1 & $0.0 \%$ & $0.0 \%$ & $0.0 \%$ & $0.0 \%$ & $0.1 \%$ & $1.1 \%$ & $1.5 \%$ \\
inert & 12 & - & $0.0 \%$ & $0.0 \%$ & $0.0 \%$ & $0.1 \%$ & $0.9 \%$ & $3.3 \%$ & $3.4 \%$ \\
mix & 73 & - & $0.3 \%$ & $2.0 \%$ & $3.2 \%$ & $5.6 \%$ & $6.8 \%$ & $7.5 \%$ & $11.3 \%$ \\
\hline Grand Total & 825 & 1 & & & & & & &
\end{tabular}

*) number of data points

${ }^{* *}$ ) number of values below the detection limit 
Value ranges for $\mathrm{Hg}$

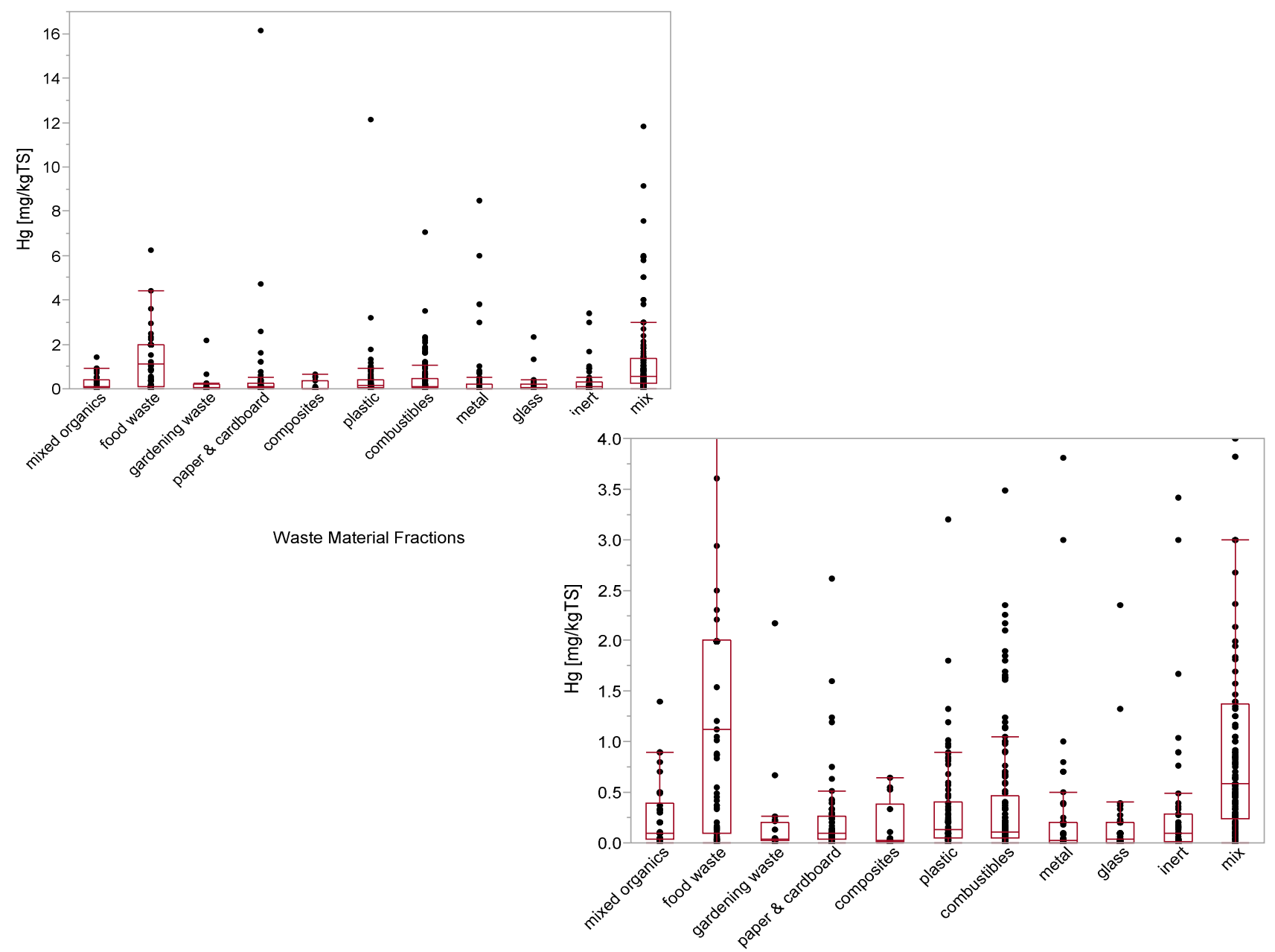

Quantiles [mg/kgTS]

\begin{tabular}{|c|c|c|c|c|c|c|c|c|c|}
\hline \multirow{2}{*}{$\begin{array}{l}\text { Waste Material } \\
\text { Fraction }\end{array}$} & \multirow[b]{2}{*}{ n_data* } & \multirow[b]{2}{*}{$\mathrm{n}_{-}<\mathrm{DL} \mathbf{L}^{\star *}$} & \multirow[b]{2}{*}{ Min } & \multirow[b]{2}{*}{$10 \%$} & \multicolumn{4}{|c|}{ Waste Material Fractions } & \multirow[b]{2}{*}{$\operatorname{Max}$} \\
\hline & & & & & $25 \%$ & Median & $75 \%$ & $90 \%$ & \\
\hline organic & 34 & 4 & 0.000 & 0.020 & 0.040 & 0.100 & 0.396 & 0.850 & 1.400 \\
\hline food waste & 99 & 41 & 0.000 & 0.020 & 0.100 & 1.120 & 2.000 & 2.000 & 6.250 \\
\hline food waste -alt ${ }^{\star \star \star}$ & 59 & 1 & 0.000 & 0.000 & 0.040 & 0.140 & 0.870 & 2.310 & 6.250 \\
\hline gardening waste & 20 & 3 & 0.000 & 0.020 & 0.023 & 0.040 & 0.198 & 0.629 & 2.170 \\
\hline paper \& cardboard & 84 & 6 & 0.000 & 0.000 & 0.030 & 0.098 & 0.265 & 0.570 & 16.160 \\
\hline composites & 14 & - & 0.000 & 0.000 & 0.008 & 0.025 & 0.380 & 0.595 & 0.640 \\
\hline plastic & 89 & 3 & 0.000 & 0.000 & 0.045 & 0.130 & 0.400 & 0.891 & 12.150 \\
\hline combustibles & 140 & 6 & 0.000 & 0.000 & 0.050 & 0.110 & 0.470 & 1.573 & 7.030 \\
\hline metal & 60 & 5 & 0.000 & 0.000 & 0.000 & 0.025 & 0.200 & 0.790 & 8.500 \\
\hline glass & 49 & 6 & 0.000 & 0.000 & 0.000 & 0.040 & 0.200 & 0.340 & 2.350 \\
\hline inert & 49 & 5 & 0.000 & 0.000 & 0.015 & 0.100 & 0.285 & 0.900 & 3.420 \\
\hline $\operatorname{mix}$ & 113 & - & 0.000 & 0.070 & 0.235 & 0.580 & 1.375 & 3.928 & 11.800 \\
\hline
\end{tabular}

Grand Total

$\left.{ }^{*}\right)$ number of data points

${ }^{* *}$ ) number of values below the detection limit

${ }^{* \star *}$ ) alternativ calculation excluding 55 data points from Wrap 2010, which were all below the same detection limit 


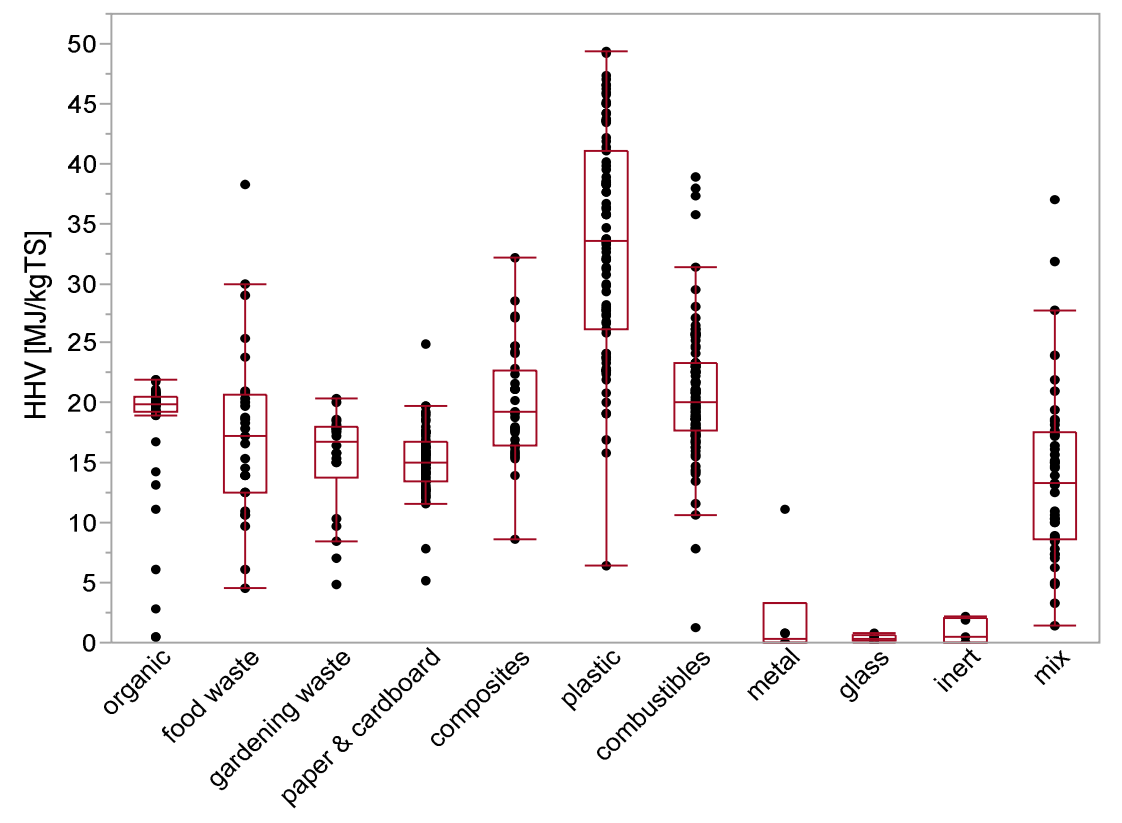

Waste Material Fractions

\section{Quantiles [MJ/kgTS]}

\begin{tabular}{|c|c|c|c|c|c|c|c|c|c|}
\hline $\begin{array}{c}\text { Waste Material } \\
\text { Fraction }\end{array}$ & n_data* & $\mathrm{n}_{-}<\mathrm{DL}$ ** & Min & $10 \%$ & $25 \%$ & Median & $75 \%$ & $90 \%$ & Max \\
\hline organic & 55 & 2 & 0.5 & 12.4 & 19.2 & 20.0 & 20.6 & 21.0 & 22.0 \\
\hline food waste & 29 & - & 4.6 & 9.6 & 12.5 & 17.3 & 20.6 & 29.0 & 38.3 \\
\hline gardening waste & 22 & - & 4.8 & 7.4 & 13.9 & 16.8 & 18.0 & 19.6 & 20.4 \\
\hline paper \& cardboard & 79 & - & 5.2 & 12.4 & 13.6 & 15.1 & 16.7 & 18.5 & 24.9 \\
\hline composites & 36 & - & 8.6 & 15.4 & 16.4 & 19.2 & 22.8 & 27.2 & 32.2 \\
\hline plastic & 91 & - & 6.5 & 22.4 & 26.1 & 33.5 & 41.0 & 45.7 & 49.4 \\
\hline combustibles & 100 & - & 1.3 & 15.5 & 17.7 & 20.0 & 23.3 & 26.2 & 38.9 \\
\hline metal & 6 & - & 0.0 & 0.0 & 0.0 & 0.4 & 3.3 & 11.1 & 11.1 \\
\hline glass & 6 & 2 & 0.0 & 0.0 & 0.1 & 0.4 & 0.6 & 0.8 & 0.8 \\
\hline inert & 5 & 1 & 0.0 & 0.0 & 0.0 & 0.5 & 2.0 & 2.2 & 2.2 \\
\hline $\operatorname{mix}$ & 45 & - & 1.4 & 5.8 & 8.6 & 13.4 & 17.5 & 22.8 & 37.0 \\
\hline
\end{tabular}

*) number of data points

${ }^{* *}$ ) number of values below the detection limit 


\section{Value ranges for $K$}

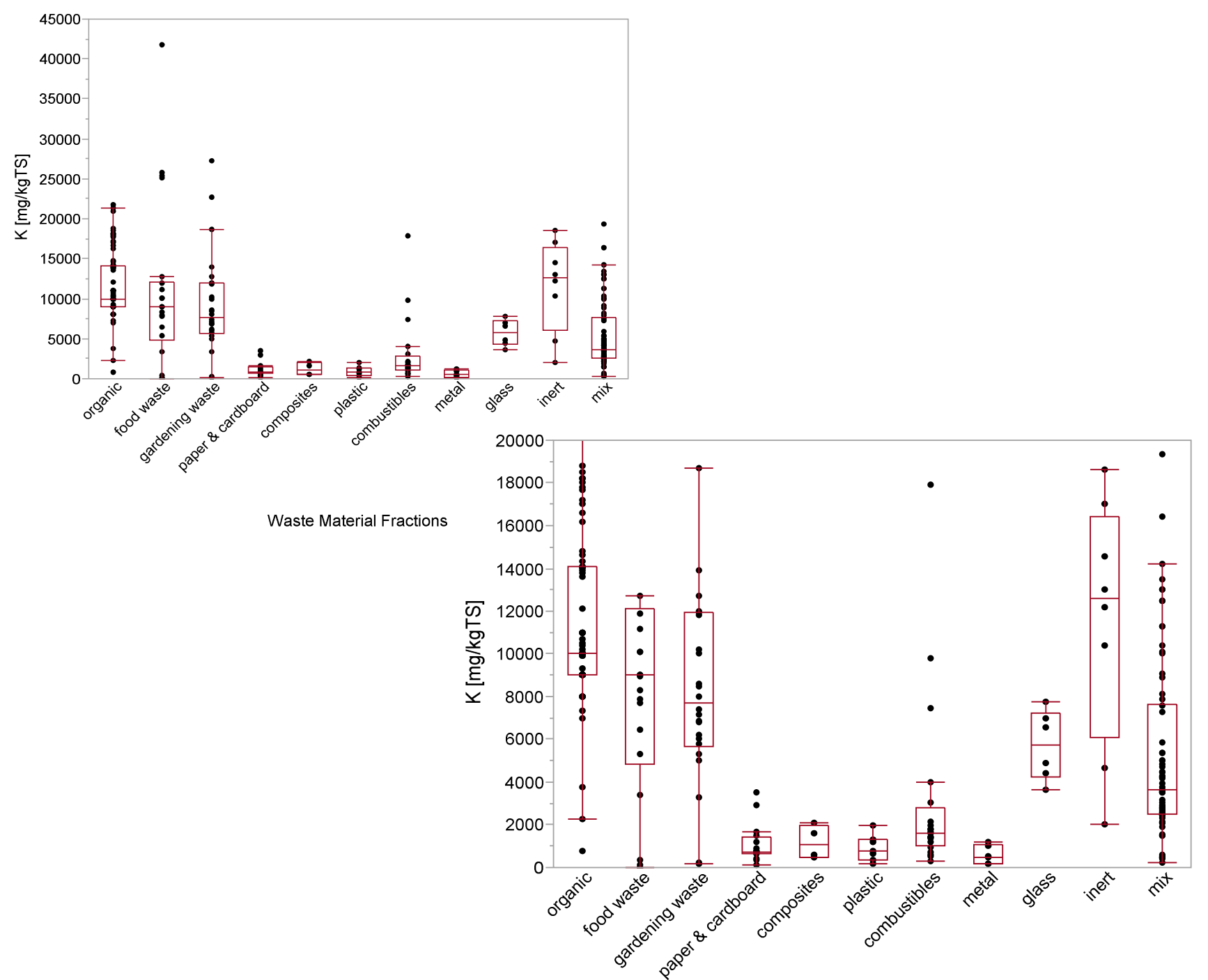

\section{Quantiles [mg/kgTS]}

Waste Material Fractions

\begin{tabular}{|c|c|c|c|c|c|c|c|c|c|}
\hline $\begin{array}{l}\text { Waste Material } \\
\text { Fraction }\end{array}$ & n_data* & $\mathrm{n}_{-}<\mathrm{DL}$ ** & Min & $10 \%$ & $25 \%$ & Median & $75 \%$ & $90 \%$ & Max \\
\hline organic & 76 & - & 795 & 8000 & 9000 & 10000 & 14075 & 18060 & 21700 \\
\hline food waste & 22 & - & 0 & 34 & 4850 & 8989 & 12100 & 25693 & 41800 \\
\hline gardening waste & 26 & - & 161 & 216 & 5677 & 7695 & 11960 & 19900 & 27300 \\
\hline paper \& cardboard & 16 & - & 118 & 297 & 676 & 743 & 1430 & 3080 & 3500 \\
\hline composites & 4 & - & 472 & 472 & 497 & 1096 & 1980 & 2100 & 2100 \\
\hline plastic & 7 & - & 190 & 190 & 372 & 750 & 1300 & 1990 & 1990 \\
\hline combustibles & 20 & - & 278 & 564 & 1016 & 1640 & 2803 & 9565 & 17900 \\
\hline metal & 6 & - & 162 & 162 & 191 & 501 & 1045 & 1190 & 1190 \\
\hline glass & 6 & - & 3650 & 3650 & 4237 & 5730 & 7195 & 7750 & 7750 \\
\hline inert & 8 & - & 2010 & 2010 & 6110 & 12600 & 16408 & 18600 & 18600 \\
\hline $\operatorname{mix}$ & 70 & - & 249 & 1484 & 2500 & 3622 & 7638 & 12497 & 19339 \\
\hline
\end{tabular}

*) number of data points

${ }^{* *}$ ) number of values below the detection limit 


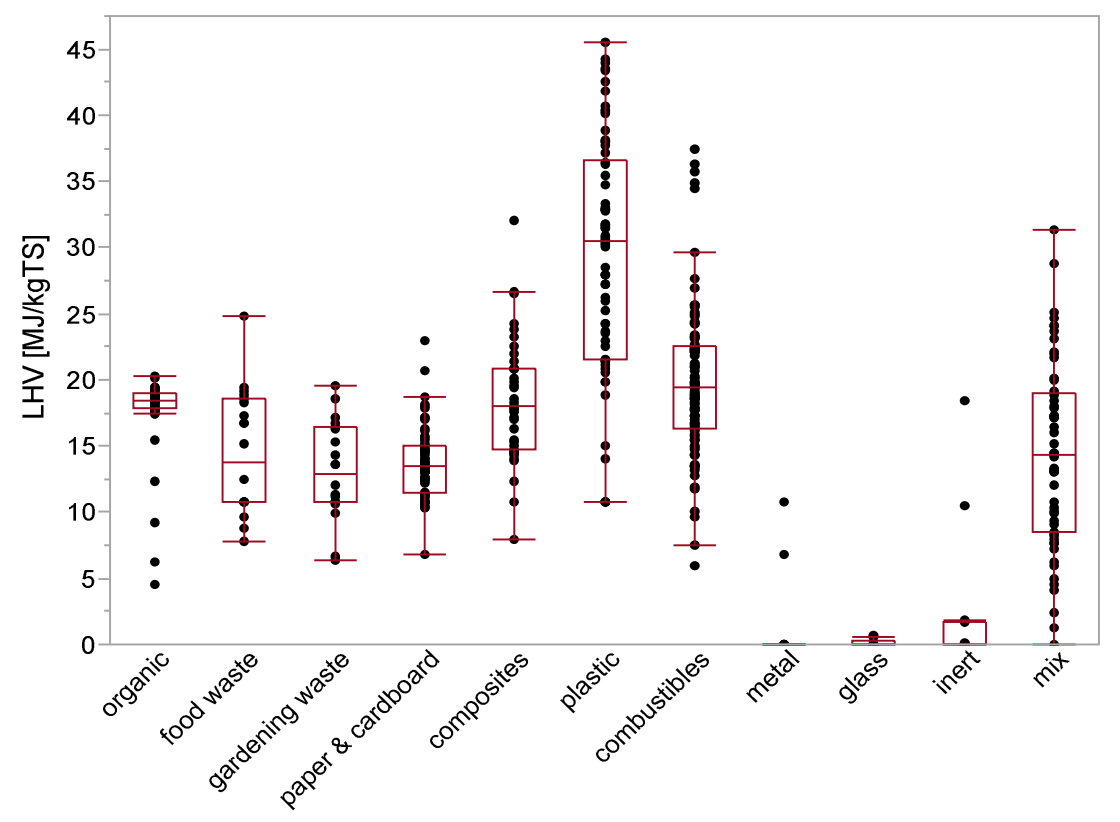

Waste Material Fractions

\section{Quantiles [MJ/kgTS]}

\begin{tabular}{|c|c|c|c|c|c|c|c|c|c|}
\hline $\begin{array}{l}\text { Waste Material } \\
\text { Fraction }\end{array}$ & n_data* & $\mathrm{n} \_<L^{* *}$ & Min & $10 \%$ & $25 \%$ & Median & $75 \%$ & $90 \%$ & Max \\
\hline organic & 50 & - & 4.6 & 15.7 & 17.9 & 18.5 & 18.9 & 19.4 & 20.3 \\
\hline food waste & 20 & - & 7.9 & 8.8 & 10.8 & 13.8 & 18.5 & 19.4 & 24.8 \\
\hline gardening waste & 20 & - & 6.4 & 7.0 & 10.8 & 12.8 & 16.5 & 18.4 & 19.5 \\
\hline paper \& cardboard & 66 & - & 6.7 & 10.8 & 11.5 & 13.4 & 15.0 & 17.3 & 23.0 \\
\hline composites & 39 & - & 7.9 & 13.9 & 14.7 & 18.0 & 20.9 & 24.2 & 32.1 \\
\hline plastic & 74 & - & 10.8 & 12.4 & 21.5 & 30.5 & 36.6 & 42.2 & 45.5 \\
\hline combustibles & 91 & - & 6.0 & 13.4 & 16.3 & 19.4 & 22.5 & 25.7 & 37.4 \\
\hline metal & 11 & - & -0.1 & -0.1 & 0.0 & 0.0 & 0.0 & 9.9 & 10.7 \\
\hline glass & 9 & - & 0.0 & 0.0 & 0.0 & 0.0 & 0.3 & 0.7 & 0.7 \\
\hline inert & 12 & - & 0.0 & 0.0 & 0.0 & 0.0 & 1.8 & 16.1 & 18.5 \\
\hline $\operatorname{mix}$ & 57 & - & 0.0 & 4.9 & 8.5 & 14.4 & 19.0 & 24.1 & 31.3 \\
\hline
\end{tabular}

$\left.{ }^{*}\right)$ number of data points

$\left.{ }^{* *}\right)$ number of values below the detection limit 


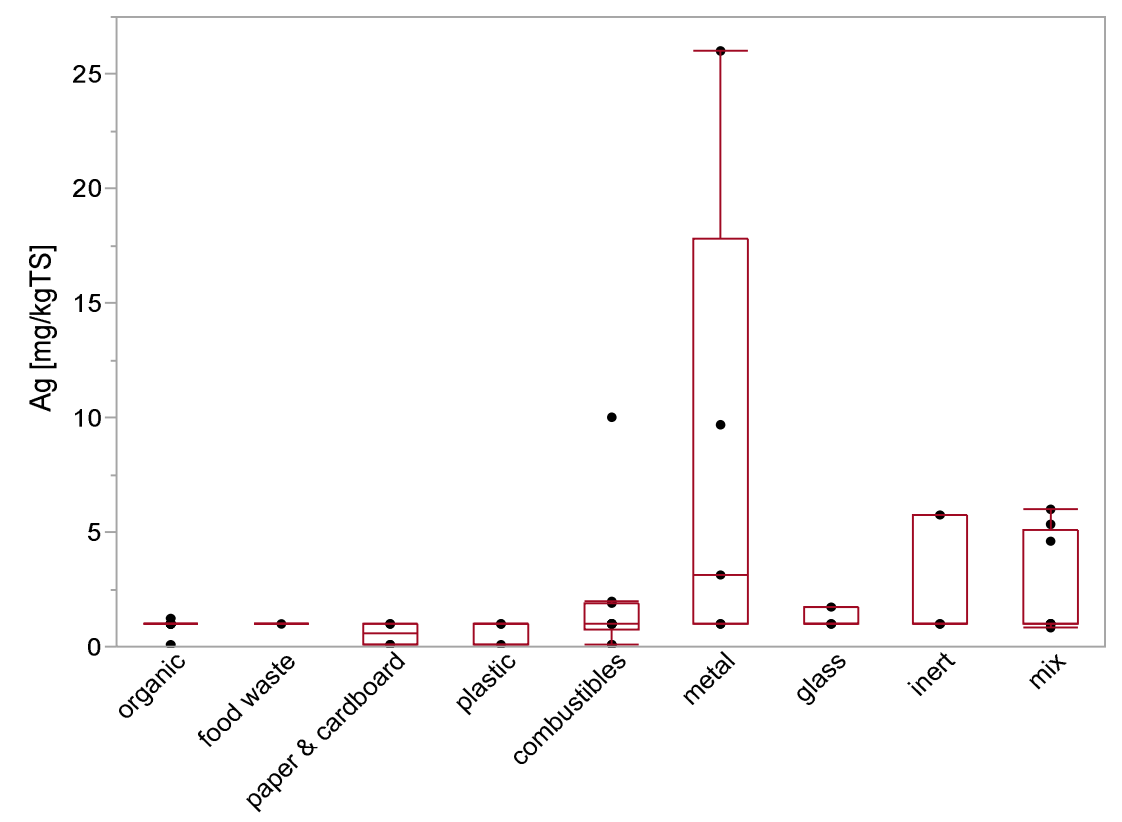

Waste Material Fractions

\section{Quantiles [mg/kgTS]}

\begin{tabular}{|c|c|c|c|c|c|c|c|c|c|}
\hline $\begin{array}{c}\text { Waste Material } \\
\text { Fraction }\end{array}$ & n_data* & $\mathrm{n}_{-}<\mathrm{DL} * *$ & Min & $10 \%$ & $25 \%$ & Median & $75 \%$ & $90 \%$ & Max \\
\hline organic & 9 & 7 & 0.08 & 0.08 & 1.00 & 1.00 & 1.00 & 1.20 & 1.20 \\
\hline food waste & 1 & 1 & 1.00 & 1.00 & 1.00 & 1.00 & 1.00 & 1.00 & 1.00 \\
\hline gardening waste & - & - & - & - & - & - & - & - & - \\
\hline paper \& cardboard & 4 & 3 & 0.08 & 0.08 & 0.09 & 0.56 & 1.00 & 1.00 & 1.00 \\
\hline composites & - & - & - & - & - & - & - & - & - \\
\hline plastic & 3 & 3 & 0.08 & 0.08 & 0.08 & 1.00 & 1.00 & 1.00 & 1.00 \\
\hline combustibles & 10 & 7 & 0.08 & 0.08 & 0.77 & 1.00 & 1.93 & 9.20 & 10.00 \\
\hline metal & 5 & 4 & 1.00 & 1.00 & 1.00 & 3.14 & 17.85 & 26.00 & 26.00 \\
\hline glass & 3 & 2 & 1.00 & 1.00 & 1.00 & 1.00 & 1.71 & 1.71 & 1.71 \\
\hline inert & 3 & 2 & 1.00 & 1.00 & 1.00 & 1.00 & 5.78 & 5.78 & 5.78 \\
\hline $\operatorname{mix}$ & 8 & 4 & 0.86 & 0.86 & 1.00 & 1.00 & 5.12 & 6.02 & 6.02 \\
\hline Total & 46 & 33 & & & & & & & \\
\hline
\end{tabular}




\section{Value ranges for $\mathrm{Al}$}

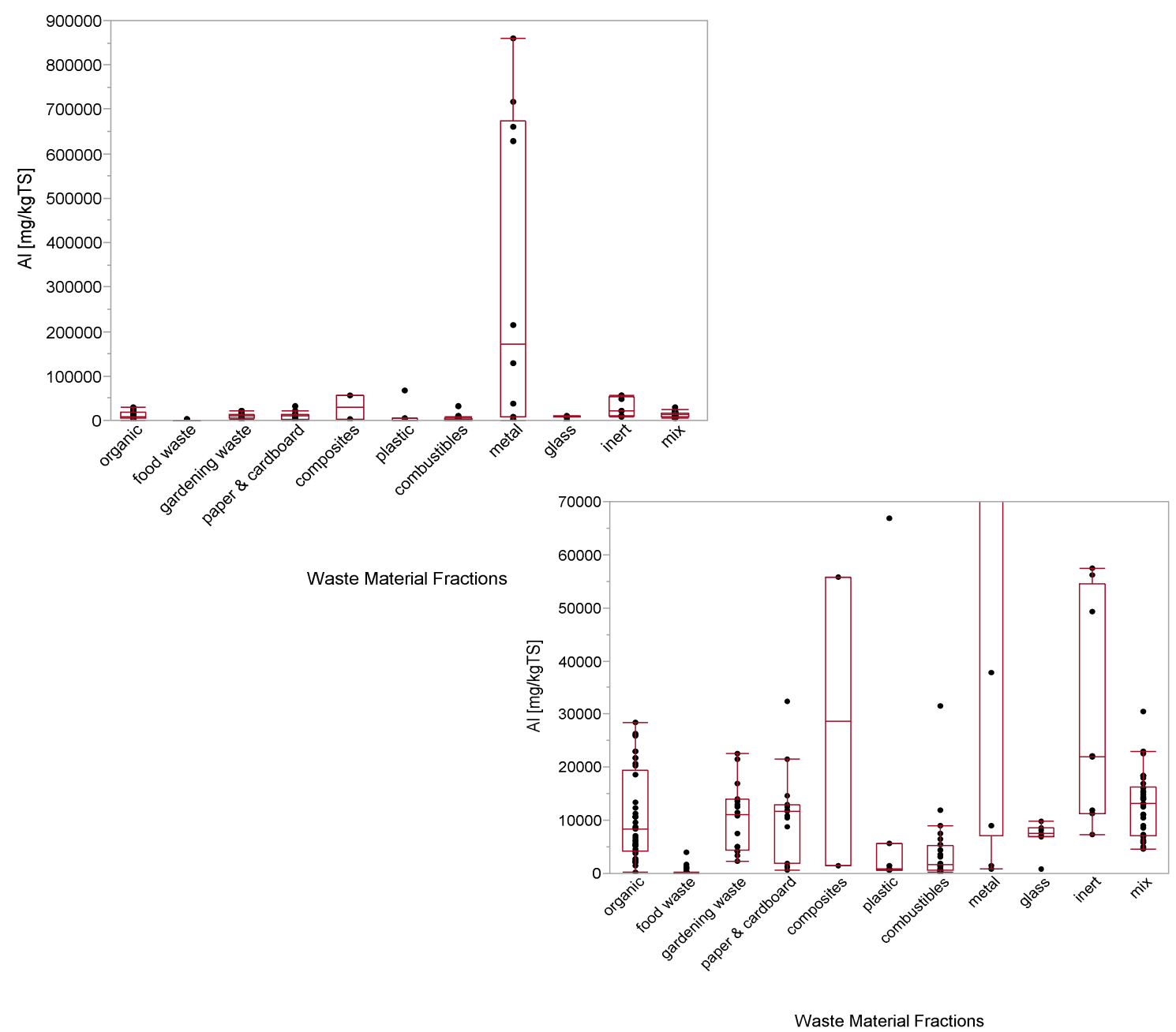

Quantiles [mg/kgTS]

\begin{tabular}{|c|c|c|c|c|c|c|c|c|c|}
\hline $\begin{array}{l}\text { Waste Material } \\
\text { Fraction }\end{array}$ & n_data* & $\mathbf{n}_{-}<\mathrm{DL}^{* *}$ & Min & $10 \%$ & $25 \%$ & Median & $75 \%$ & $90 \%$ & Max \\
\hline organic & 41 & - & 286 & 2160 & 4100 & 8400 & 19464 & 25412 & 28333 \\
\hline food waste & 47 & - & 12 & 21 & 30 & 46 & 103 & 851 & 3890 \\
\hline gardening waste & 16 & - & 2360 & 3088 & 4453 & 11178 & 13916 & 21859 & 22550 \\
\hline paper \& cardboard & 15 & - & 681 & 1033 & 1800 & 11700 & 12933 & 25870 & 32425 \\
\hline composites & 2 & - & 1430 & 1430 & 1430 & 28615 & 55800 & 55800 & 55800 \\
\hline plastic & 7 & - & 692 & 692 & 720 & 820 & 5650 & 66800 & 66800 \\
\hline combustibles & 24 & - & 200 & 250 & 678 & 1570 & 5150 & 10500 & 31600 \\
\hline metal & 10 & - & 860 & 926 & 7055 & 171500 & 674500 & 846700 & 861000 \\
\hline glass & 7 & - & 750 & 750 & 6860 & 7620 & 8470 & 9870 & 9870 \\
\hline inert & 8 & - & 7300 & 7300 & 11361 & 22000 & 54483 & 57500 & 57500 \\
\hline mix & 34 & - & 4670 & 5435 & 7118 & 13080 & 16280 & 20478 & 30500 \\
\hline
\end{tabular}

Grand Total

209

*) number of data points

$\left.{ }^{\star \star}\right)$ number of values below the detection limit 


\section{Value ranges for As}

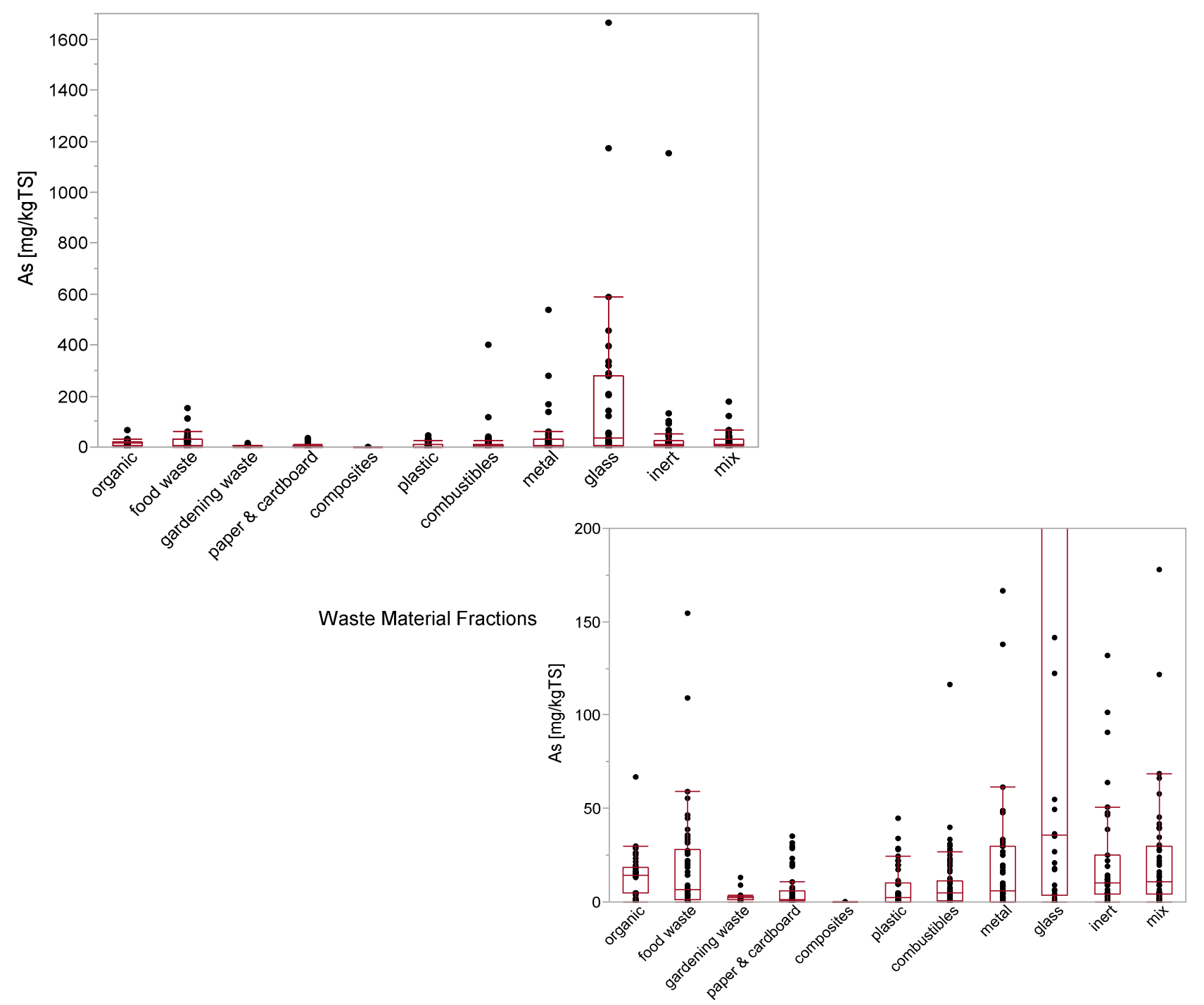

\section{Quantiles [mg/kgTS]}

\begin{tabular}{|c|c|c|c|c|c|c|c|c|c|}
\hline \multirow{2}{*}{$\begin{array}{c}\text { Waste Material } \\
\text { Fraction }\end{array}$} & \multirow[b]{2}{*}{ n_data* } & \multirow[b]{2}{*}{$\mathrm{n}_{-}<\mathrm{DL} * *$} & \multirow[b]{2}{*}{ Min } & \multicolumn{6}{|c|}{ Waste Material Fractions } \\
\hline & & & & $10 \%$ & $25 \%$ & Median & $75 \%$ & $90 \%$ & $\operatorname{Max}$ \\
\hline organic & 48 & 8 & 0.200 & 0.699 & 5.000 & 14.565 & 18.605 & 26.385 & 67.000 \\
\hline food waste & 54 & 1 & 0.000 & 0.000 & 1.000 & 6.750 & 28.350 & 45.550 & 154.400 \\
\hline gardening waste & 18 & - & 0.000 & 0.495 & 1.188 & 2.405 & 3.080 & 9.582 & 13.020 \\
\hline paper \& cardboard & 57 & 4 & 0.000 & 0.126 & 0.345 & 1.090 & 6.100 & 24.100 & 35.100 \\
\hline composites & 3 & - & 0.140 & 0.140 & 0.140 & 0.200 & 0.200 & 0.200 & 0.200 \\
\hline plastic & 46 & 5 & 0.000 & 0.000 & 0.215 & 2.250 & 10.075 & 25.580 & 44.800 \\
\hline combustibles & 89 & 10 & 0.000 & 0.000 & 0.305 & 5.000 & 11.340 & 28.170 & 400.000 \\
\hline metal & 45 & 1 & 0.000 & 0.000 & 0.000 & 6.200 & 29.800 & 92.040 & 539.000 \\
\hline glass & 36 & - & 0.000 & 0.000 & 3.800 & 35.900 & 280.475 & 497.680 & 1664.400 \\
\hline inert & 39 & 2 & 0.000 & 0.000 & 4.000 & 10.400 & 25.000 & 91.000 & 1153.000 \\
\hline $\operatorname{mix}$ & 50 & 2 & 0.000 & 1.633 & 4.060 & 10.950 & 30.068 & 56.465 & 177.990 \\
\hline
\end{tabular}

*) number of data points

${ }^{* *}$ ) number of values below the detection limit 


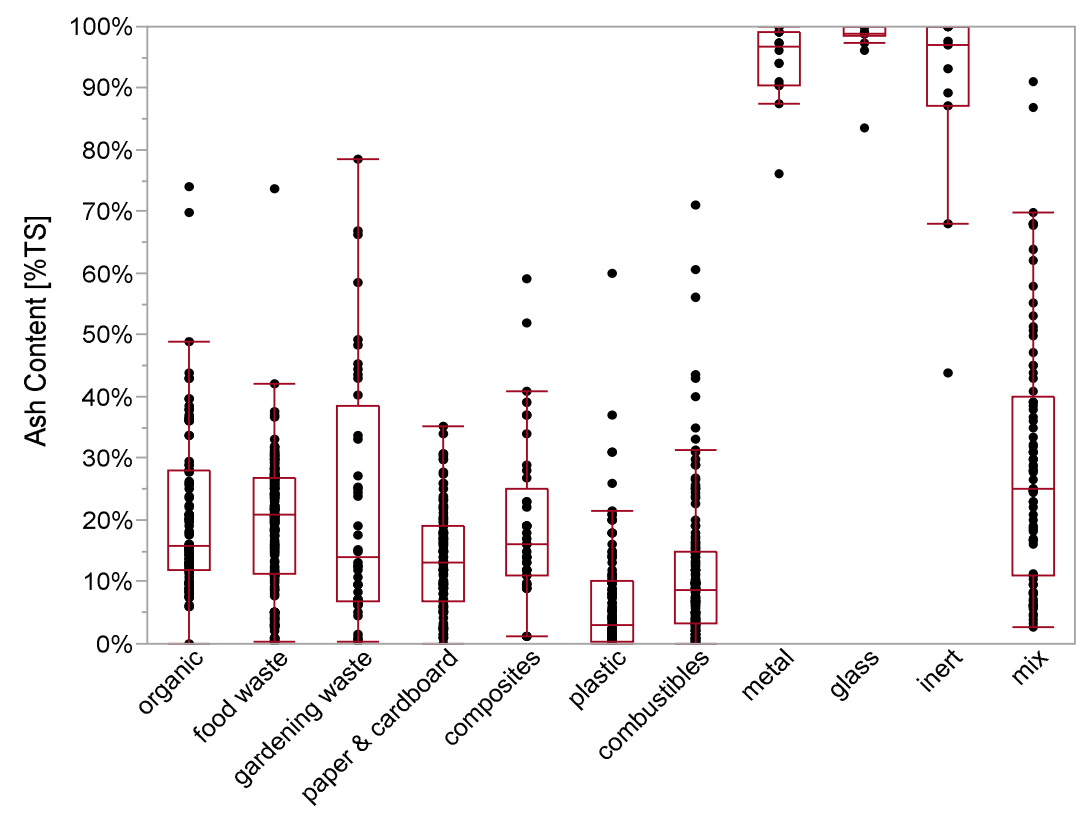

Waste Material Fractions

\section{Quantiles [\%TS]}

\begin{tabular}{|c|c|c|c|c|c|c|c|c|c|}
\hline $\begin{array}{l}\text { Waste Material } \\
\text { Fraction }\end{array}$ & n_data* & $\mathrm{n}_{-}<\mathrm{DL}$ ** & Min & $10 \%$ & $25 \%$ & Median & $75 \%$ & $90 \%$ & Max \\
\hline organic & 106 & - & $0.0 \%$ & $8.5 \%$ & $12.0 \%$ & $15.7 \%$ & $28.0 \%$ & $38.0 \%$ & $74.0 \%$ \\
\hline food waste & 196 & - & $0.2 \%$ & $3.8 \%$ & $11.5 \%$ & $20.9 \%$ & $26.9 \%$ & $30.0 \%$ & $73.7 \%$ \\
\hline gardening waste & 44 & - & $0.4 \%$ & $3.0 \%$ & $6.8 \%$ & $14.0 \%$ & $38.6 \%$ & $53.9 \%$ & $78.4 \%$ \\
\hline paper \& cardboard & 112 & - & $0.0 \%$ & $2.4 \%$ & $6.8 \%$ & $13.0 \%$ & $19.0 \%$ & $25.7 \%$ & $35.4 \%$ \\
\hline composites & 41 & - & $1.2 \%$ & $9.0 \%$ & $11.0 \%$ & $16.0 \%$ & $25.0 \%$ & $38.6 \%$ & $59.0 \%$ \\
\hline plastic & 119 & - & $0.0 \%$ & $0.1 \%$ & $0.4 \%$ & $3.0 \%$ & $10.0 \%$ & $18.0 \%$ & $60.0 \%$ \\
\hline combustibles & 146 & - & $0.0 \%$ & $1.0 \%$ & $3.2 \%$ & $8.7 \%$ & $15.1 \%$ & $26.6 \%$ & $71.0 \%$ \\
\hline metal & 18 & - & $76.1 \%$ & $86.5 \%$ & $90.5 \%$ & $96.7 \%$ & $99.3 \%$ & $100.0 \%$ & $100.0 \%$ \\
\hline glass & 14 & - & $83.5 \%$ & $89.8 \%$ & $98.5 \%$ & $98.9 \%$ & $100.0 \%$ & $100.0 \%$ & $100.0 \%$ \\
\hline inert & 11 & - & $43.9 \%$ & $48.7 \%$ & $87.2 \%$ & $97.0 \%$ & $100.0 \%$ & $100.0 \%$ & $100.0 \%$ \\
\hline $\operatorname{mix}$ & 85 & - & $2.6 \%$ & $6.1 \%$ & $11.0 \%$ & $25.0 \%$ & $39.9 \%$ & $62.8 \%$ & $91.0 \%$ \\
\hline
\end{tabular}

*) number of data points

${ }^{* *}$ ) number of values below the detection limit 


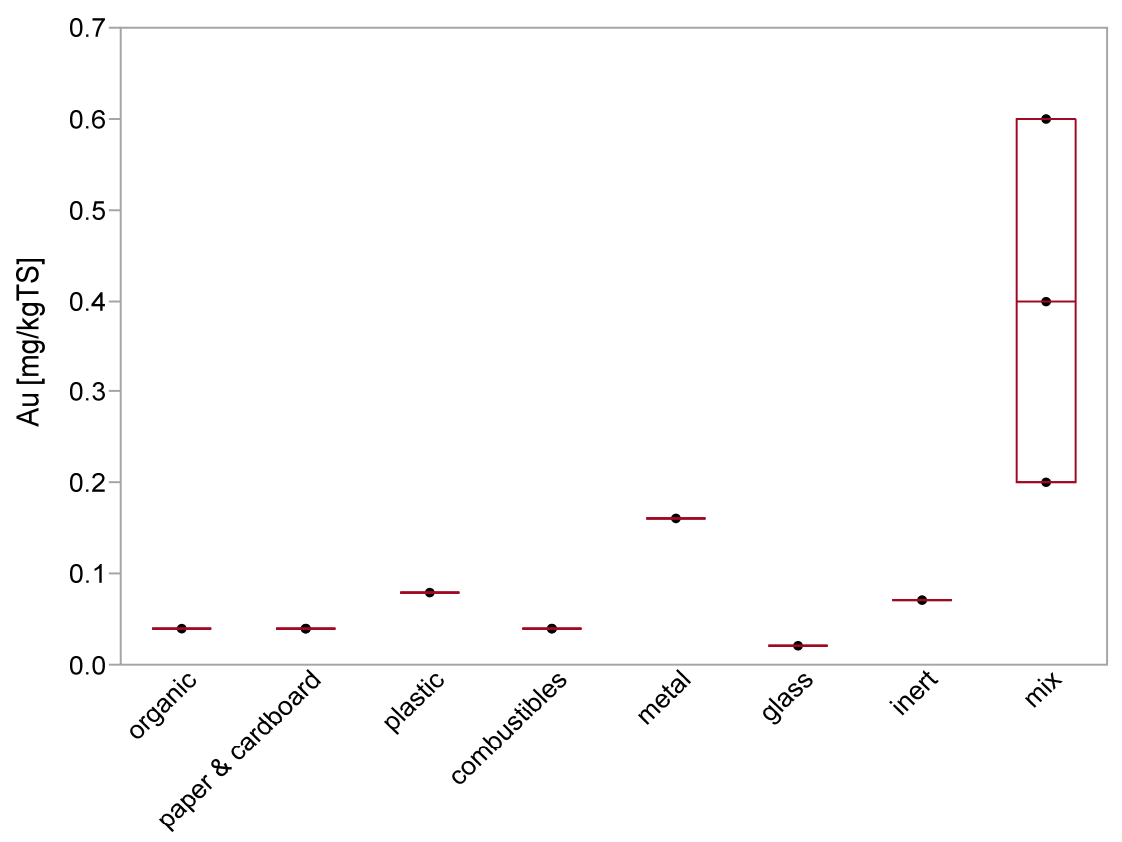

Waste Material Fractions

\section{Quantiles [mg/kgTS]}

\begin{tabular}{|c|c|c|c|c|c|c|c|c|c|}
\hline $\begin{array}{c}\text { Waste Material } \\
\text { Fraction }\end{array}$ & n_data* & $\mathrm{n}_{-}<\mathrm{DL} \mathbf{L}^{* *}$ & Min & $10 \%$ & $25 \%$ & Median & $75 \%$ & $90 \%$ & Max \\
\hline organic & 1 & 1 & 0.04 & 0.04 & 0.04 & 0.04 & 0.04 & 0.04 & 0.04 \\
\hline food waste & - & - & - & - & - & - & - & - & - \\
\hline gardening waste & - & - & - & - & - & - & - & - & - \\
\hline paper \& cardboard & 2 & 2 & 0.04 & 0.04 & 0.04 & 0.04 & 0.04 & 0.04 & 0.04 \\
\hline composites & - & - & - & - & - & - & - & - & - \\
\hline plastic & 1 & 1 & 0.08 & 0.08 & 0.08 & 0.08 & 0.08 & 0.08 & 0.08 \\
\hline combustibles & 2 & 2 & 0.04 & 0.04 & 0.04 & 0.04 & 0.04 & 0.04 & 0.04 \\
\hline metal & 1 & - & 0.16 & 0.16 & 0.16 & 0.16 & 0.16 & 0.16 & 0.16 \\
\hline glass & 1 & 1 & 0.02 & 0.02 & 0.02 & 0.02 & 0.02 & 0.02 & 0.02 \\
\hline inert & 1 & - & 0.07 & 0.07 & 0.07 & 0.07 & 0.07 & 0.07 & 0.07 \\
\hline $\operatorname{mix}$ & 3 & - & 0.20 & 0.20 & 0.20 & 0.40 & 0.60 & 0.60 & 0.60 \\
\hline
\end{tabular}

*) number of data points

$\left.{ }^{\star *}\right)$ number of values below the detection limit 


\section{Value ranges for $B$}

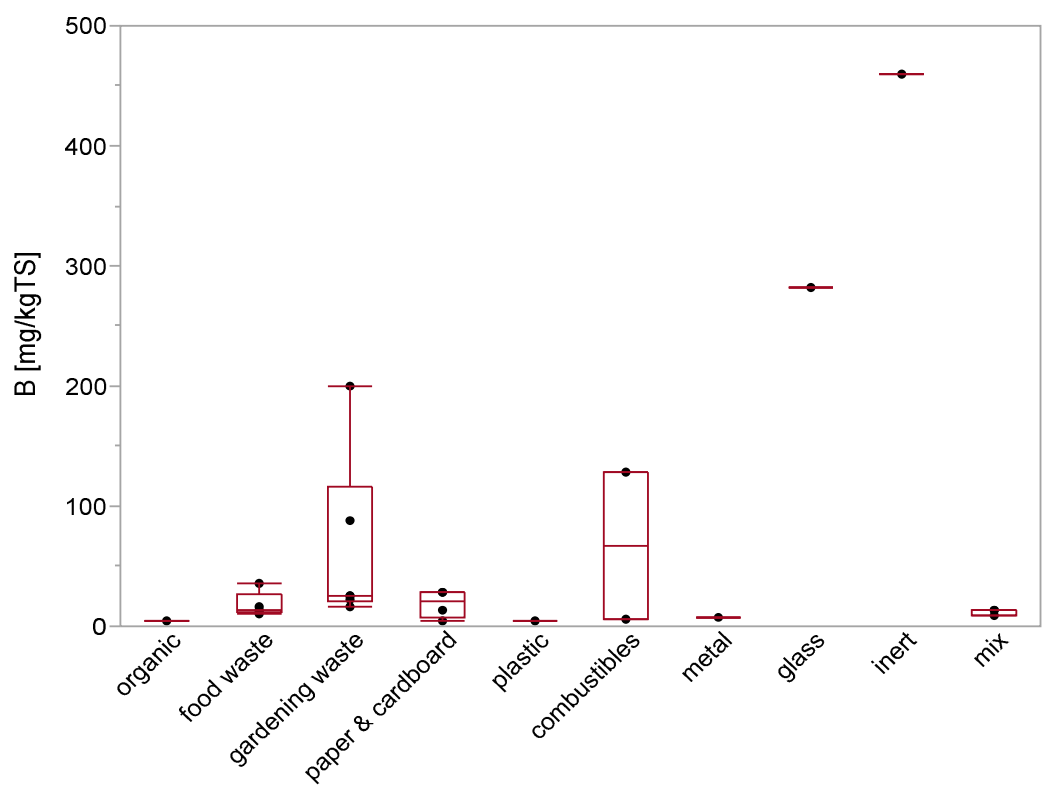

Waste Material Fractions

\section{Quantiles [mg/kgTS]}

\begin{tabular}{|c|c|c|c|c|c|c|c|c|c|}
\hline $\begin{array}{c}\text { Waste Material } \\
\text { Fraction }\end{array}$ & n_data* & $\mathrm{n}_{-}<\mathrm{DL}$ ** & Min & $10 \%$ & $25 \%$ & Median & $75 \%$ & $90 \%$ & Max \\
\hline organic & 1 & - & 5.1 & 5.1 & 5.1 & 5.1 & 5.1 & 5.1 & 5.1 \\
\hline food waste & 5 & - & 11.0 & 11.0 & 11.5 & 13.0 & 26.5 & 36.0 & 36.0 \\
\hline gardening waste & 6 & - & 17.0 & 17.0 & 20.8 & 25.5 & 116.0 & 200.0 & 200.0 \\
\hline paper \& cardboard & 4 & - & 4.6 & 4.6 & 6.9 & 21.0 & 28.5 & 28.7 & 28.7 \\
\hline composites & - & - & - & - & - & - & - & - & - \\
\hline plastic & 1 & - & 4.1 & 4.1 & 4.1 & 4.1 & 4.1 & 4.1 & 4.1 \\
\hline combustibles & 2 & - & 5.6 & 5.6 & 5.6 & 66.8 & 128.0 & 128.0 & 128.0 \\
\hline metal & 1 & - & 7.4 & 7.4 & 7.4 & 7.4 & 7.4 & 7.4 & 7.4 \\
\hline glass & 1 & - & 282.0 & 282.0 & 282.0 & 282.0 & 282.0 & 282.0 & 282.0 \\
\hline inert & 1 & - & 459.0 & 459.0 & 459.0 & 459.0 & 459.0 & 459.0 & 459.0 \\
\hline $\operatorname{mix}$ & 3 & - & 8.6 & 8.6 & 8.6 & 14.0 & 14.0 & 14.0 & 14.0 \\
\hline
\end{tabular}

$\left.{ }^{*}\right)$ number of data points

**) number of values below the detection limit 


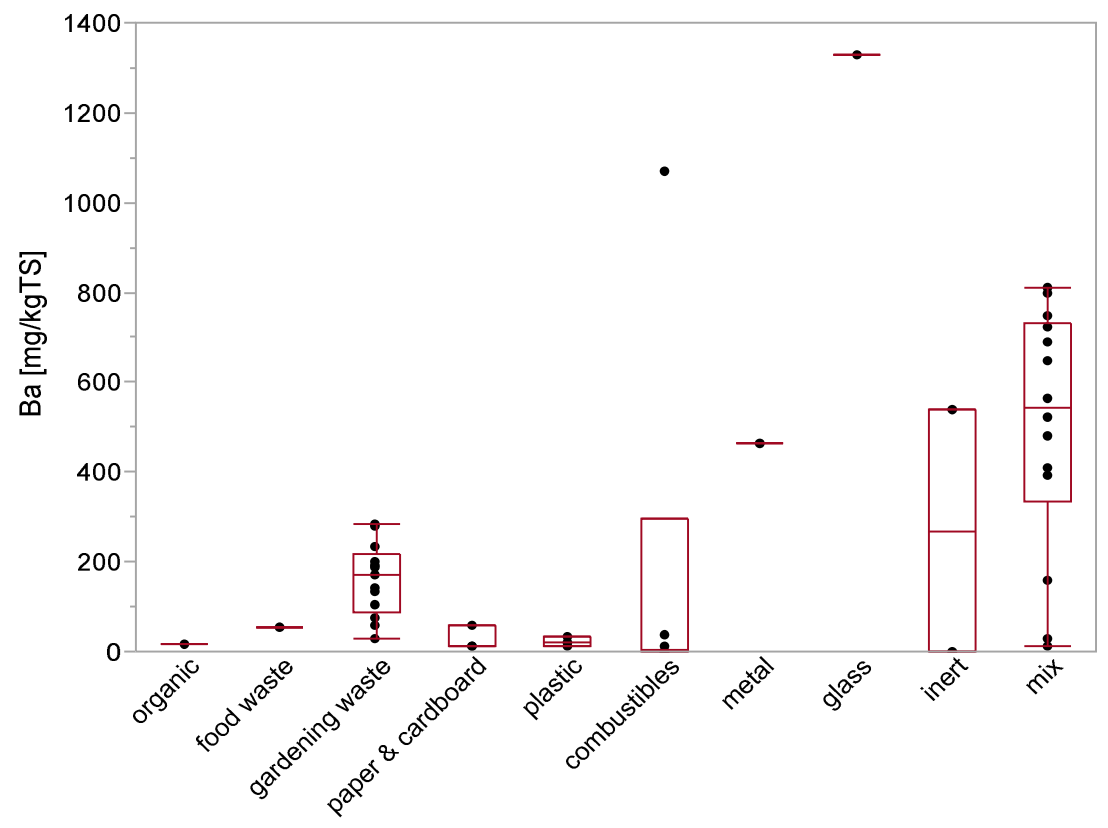

Waste Material Fractions

\section{Quantiles [mg/kgTS]}

\begin{tabular}{|c|c|c|c|c|c|c|c|c|c|}
\hline $\begin{array}{l}\text { Waste Material } \\
\text { Fraction }\end{array}$ & n_data* & $\mathbf{n}_{-}<\mathrm{DL}^{* *}$ & Min & $10 \%$ & $25 \%$ & Median & $75 \%$ & $90 \%$ & Max \\
\hline organic & 1 & - & 18.1 & 18.1 & 18.1 & 18.1 & 18.1 & 18.1 & 18.1 \\
\hline food waste & 1 & - & 55.1 & 55.1 & 55.1 & 55.1 & 55.1 & 55.1 & 55.1 \\
\hline gardening waste & 13 & - & 27.8 & 39.5 & 89.1 & 170.2 & 216.1 & 282.7 & 283.3 \\
\hline paper \& cardboard & 3 & - & 12.3 & 12.3 & 12.3 & 12.5 & 60.1 & 60.1 & 60.1 \\
\hline composites & - & - & - & - & - & - & - & - & - \\
\hline plastic & 3 & - & 12.8 & 12.8 & 12.8 & 22.5 & 33.4 & 33.4 & 33.4 \\
\hline combustibles & 6 & - & 0.0 & 0.0 & 0.0 & 5.3 & 297.5 & 1071.0 & 1071.0 \\
\hline metal & 1 & - & 464.0 & 464.0 & 464.0 & 464.0 & 464.0 & 464.0 & 464.0 \\
\hline glass & 1 & - & 1330.0 & 1330.0 & 1330.0 & 1330.0 & 1330.0 & 1330.0 & 1330.0 \\
\hline inert & 2 & - & 0.0 & 0.0 & 0.0 & 269.5 & 539.0 & 539.0 & 539.0 \\
\hline $\operatorname{mix}$ & 14 & - & 13.6 & 21.0 & 335.8 & 543.5 & 730.0 & 804.5 & 809.0 \\
\hline Grand Total & 45 & 0 & & & & & & & \\
\hline
\end{tabular}




\section{Value ranges for $\mathrm{Be}$}

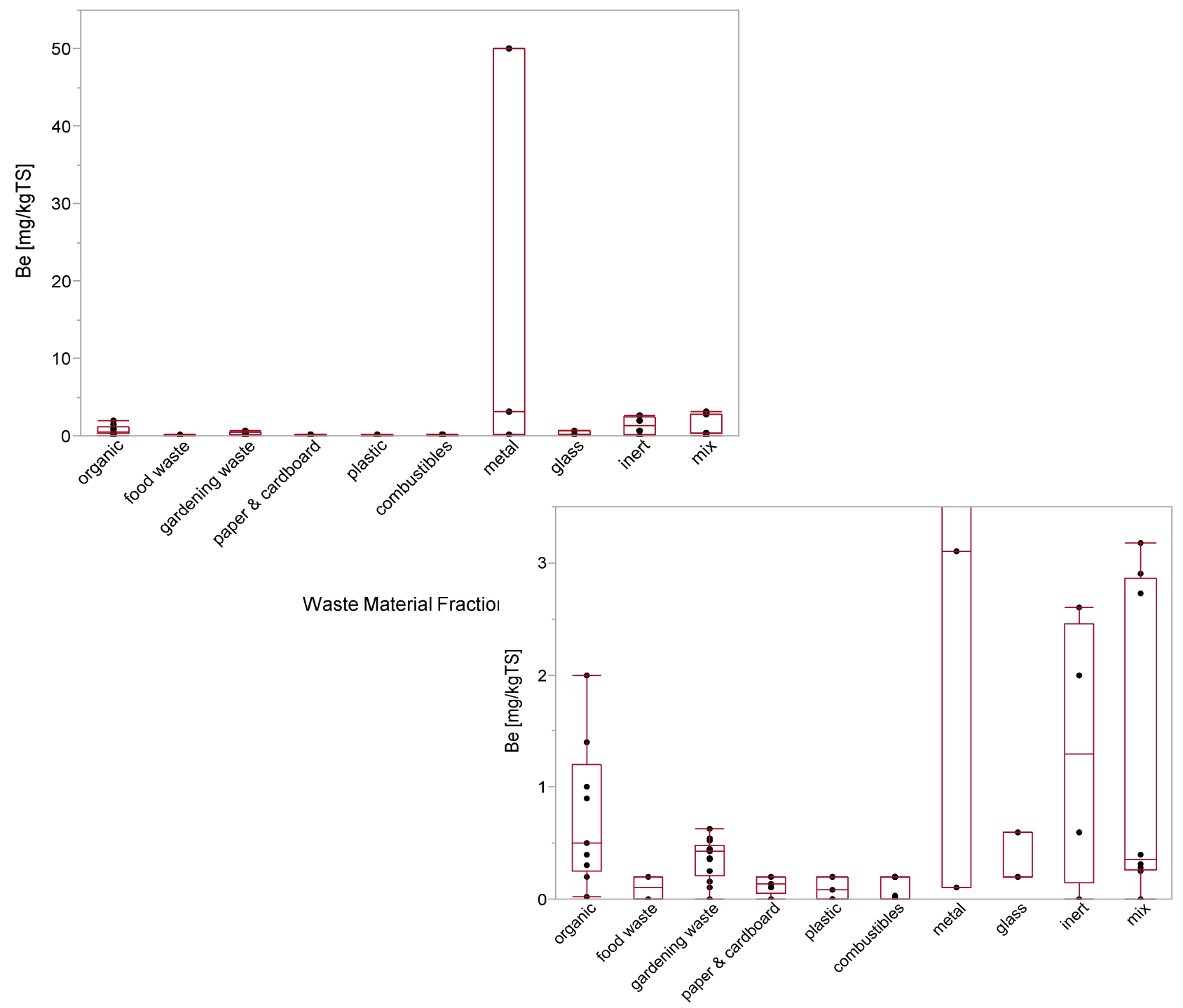

\section{Quantiles [mg/kgTS]}

Waste Material Fractions

\begin{tabular}{|c|c|c|c|c|c|c|c|c|c|}
\hline $\begin{array}{c}\text { Waste Material } \\
\text { Fraction }\end{array}$ & n_data* & $n \_<D L^{* *}$ & Min & $10 \%$ & $25 \%$ & Median & $75 \%$ & $90 \%$ & Max \\
\hline organic & 9 & 1 & 0.02 & 0.02 & 0.25 & 0.50 & 1.20 & 2.00 & 2.00 \\
\hline food waste & 2 & - & 0.00 & 0.00 & 0.00 & 0.10 & 0.20 & 0.20 & 0.20 \\
\hline gardening waste & 13 & - & 0.00 & 0.04 & 0.21 & 0.43 & 0.49 & 0.59 & 0.63 \\
\hline paper \& cardboard & 5 & - & 0.00 & 0.00 & 0.05 & 0.14 & 0.20 & 0.20 & 0.20 \\
\hline composites & - & - & - & - & - & - & - & - & - \\
\hline plastic & 5 & 1 & 0.00 & 0.00 & 0.00 & 0.08 & 0.20 & 0.20 & 0.20 \\
\hline combustibles & 14 & & 0.00 & 0.00 & 0.00 & 0.20 & 0.20 & 0.20 & 0.20 \\
\hline metal & 3 & 1 & 0.10 & 0.10 & 0.10 & 3.10 & 50.00 & 50.00 & 50.00 \\
\hline glass & 3 & - & 0.20 & 0.20 & 0.20 & 0.20 & 0.60 & 0.60 & 0.60 \\
\hline inert & 4 & - & 0.00 & 0.00 & 0.15 & 1.30 & 2.45 & 2.60 & 2.60 \\
\hline $\operatorname{mix}$ & 8 & - & 0.00 & 0.00 & 0.26 & 0.36 & 2.86 & 3.18 & 3.18 \\
\hline
\end{tabular}

*) number of data points

${ }^{* *}$ ) number of values below the detection limit 


\section{Value ranges for $\mathrm{Br}$}

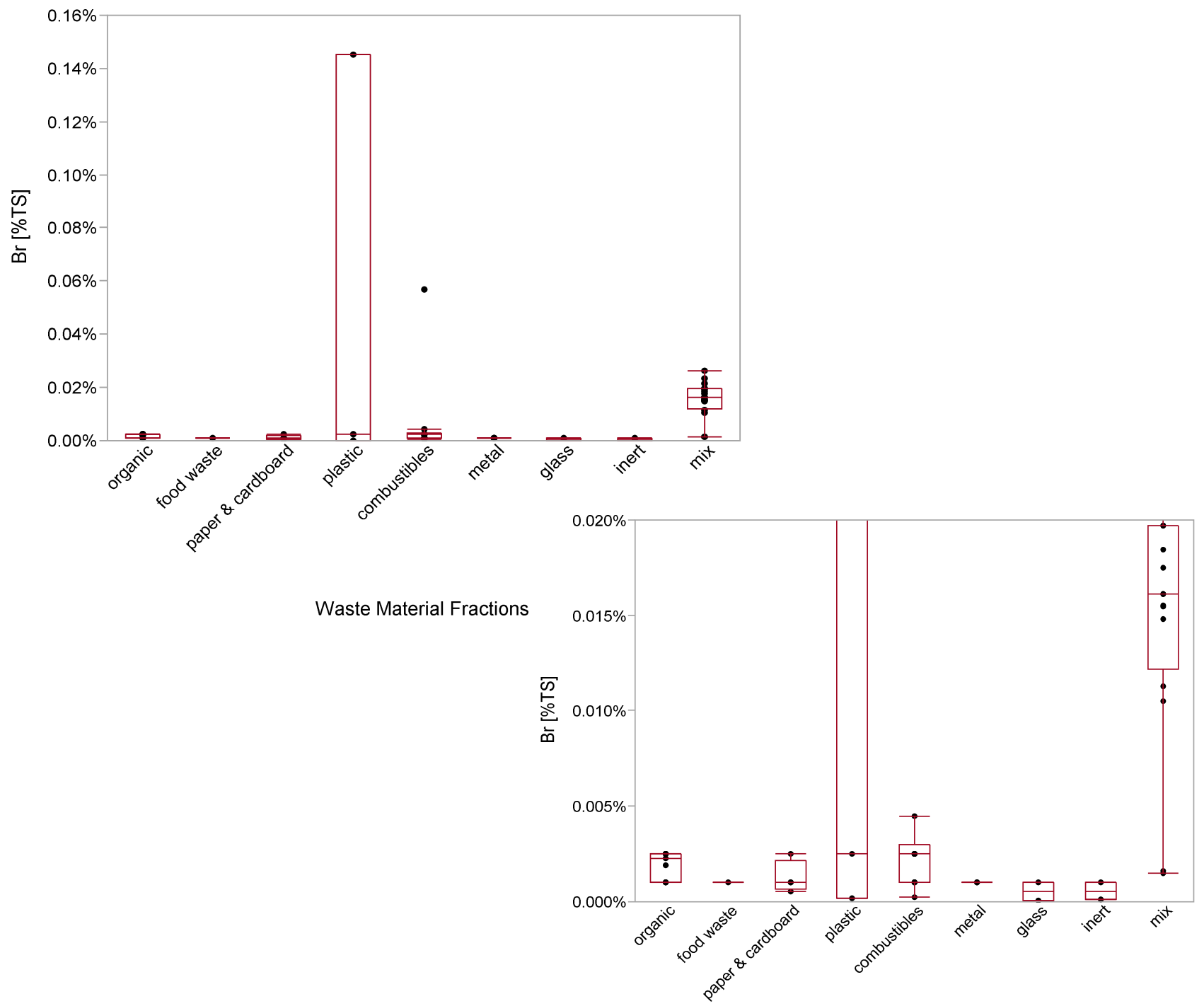

Quantiles [\%TS]

Waste Material Fractions

\section{Waste Material}

\begin{tabular}{|c|c|c|c|c|c|c|c|c|c|}
\hline Fraction & n_data* & $\mathrm{n} \_\mathrm{DL}^{* *}$ & Min & $10 \%$ & $25 \%$ & Median & $75 \%$ & $90 \%$ & Max \\
\hline organic & 9 & 7 & $0.001 \%$ & $0.001 \%$ & $0.001 \%$ & $0.002 \%$ & $0.003 \%$ & $0.003 \%$ & $0.003 \%$ \\
\hline food waste & 1 & 1 & $0.001 \%$ & $0.001 \%$ & $0.001 \%$ & $0.001 \%$ & $0.001 \%$ & $0.001 \%$ & $0.001 \%$ \\
\hline gardening waste & - & - & - & - & - & - & - & - & - \\
\hline paper \& cardboard & 4 & 2 & $0.001 \%$ & $0.001 \%$ & $0.001 \%$ & $0.001 \%$ & $0.002 \%$ & $0.003 \%$ & $0.003 \%$ \\
\hline composites & - & - & - & - & - & - & - & - & - \\
\hline plastic & 3 & 1 & $0.000 \%$ & $0.000 \%$ & $0.000 \%$ & $0.003 \%$ & $0.145 \%$ & $0.145 \%$ & $0.145 \%$ \\
\hline combustibles & 10 & 7 & $0.000 \%$ & $0.000 \%$ & $0.001 \%$ & $0.003 \%$ & $0.003 \%$ & $0.052 \%$ & $0.057 \%$ \\
\hline metal & 2 & 2 & $0.001 \%$ & $0.001 \%$ & $0.001 \%$ & $0.001 \%$ & $0.001 \%$ & $0.001 \%$ & $0.001 \%$ \\
\hline glass & 2 & 2 & $0.000 \%$ & $0.000 \%$ & $0.000 \%$ & $0.001 \%$ & $0.001 \%$ & $0.001 \%$ & $0.001 \%$ \\
\hline inert & 2 & 1 & $0.000 \%$ & $0.000 \%$ & $0.000 \%$ & $0.001 \%$ & $0.001 \%$ & $0.001 \%$ & $0.001 \%$ \\
\hline $\operatorname{mix}$ & 16 & 1 & $0.002 \%$ & $0.002 \%$ & $0.012 \%$ & $0.016 \%$ & $0.020 \%$ & $0.024 \%$ & $0.026 \%$ \\
\hline
\end{tabular}

*) number of data points

${ }^{* *}$ ) number of values below the detection limit 


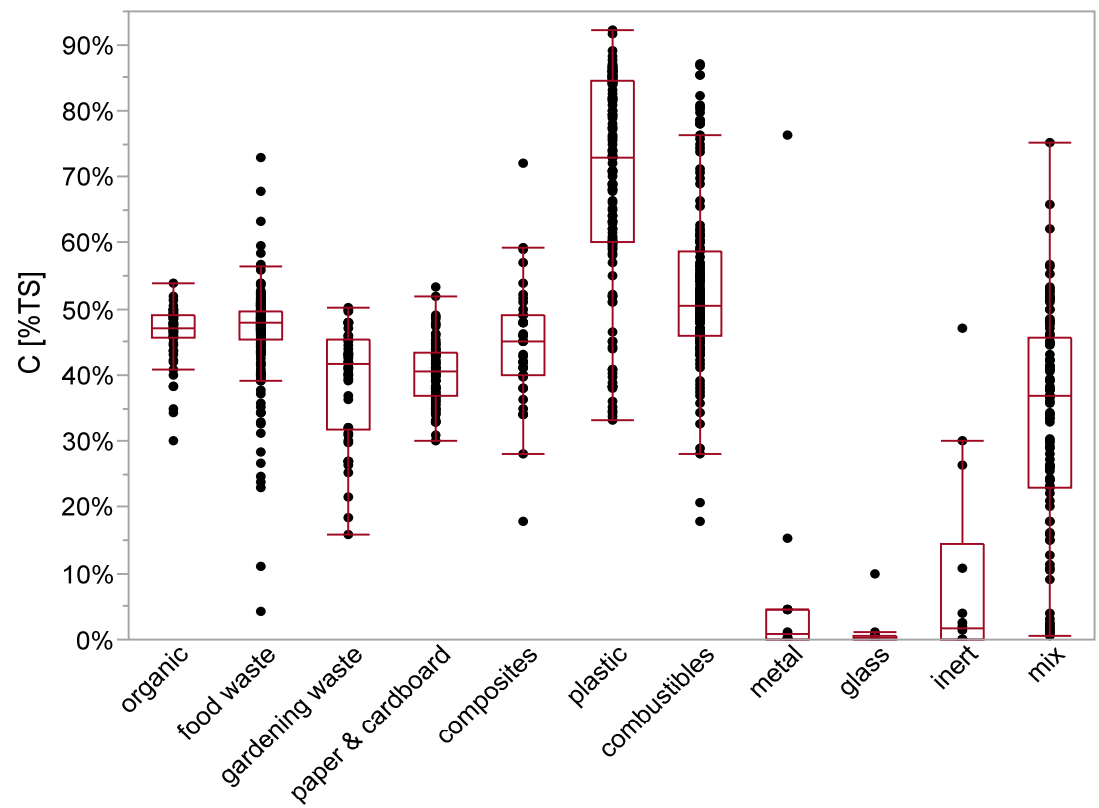

Waste Material Fractions

\section{Quantiles [\%TS]}

\begin{tabular}{|c|c|c|c|c|c|c|c|c|c|}
\hline $\begin{array}{c}\text { Waste Material } \\
\text { Fraction }\end{array}$ & n_data* & $\mathrm{n}_{-}<\mathrm{DL} * *$ & Min & $10 \%$ & $25 \%$ & Median & $75 \%$ & $90 \%$ & Max \\
\hline organic & 61 & - & $30.0 \%$ & $40.2 \%$ & $45.6 \%$ & $47.2 \%$ & $49.0 \%$ & $50.0 \%$ & $54.0 \%$ \\
\hline food waste & 211 & - & $4.4 \%$ & $39.5 \%$ & $45.2 \%$ & $47.9 \%$ & $49.8 \%$ & $51.6 \%$ & $73.0 \%$ \\
\hline gardening waste & 49 & - & $15.8 \%$ & $26.5 \%$ & $31.7 \%$ & $41.8 \%$ & $45.5 \%$ & $47.8 \%$ & $50.1 \%$ \\
\hline paper \& cardboard & 113 & - & $30.2 \%$ & $34.4 \%$ & $37.0 \%$ & $40.5 \%$ & $43.3 \%$ & $46.2 \%$ & $53.4 \%$ \\
\hline composites & 42 & - & $18.0 \%$ & $34.0 \%$ & $39.9 \%$ & $45.0 \%$ & $49.0 \%$ & $56.1 \%$ & $72.0 \%$ \\
\hline plastic & 137 & - & $33.3 \%$ & $40.7 \%$ & $60.0 \%$ & $73.0 \%$ & $84.5 \%$ & $86.1 \%$ & $92.1 \%$ \\
\hline combustibles & 152 & - & $18.0 \%$ & $42.6 \%$ & $46.1 \%$ & $50.5 \%$ & $58.6 \%$ & $76.2 \%$ & $87.1 \%$ \\
\hline metal & 14 & - & $0.0 \%$ & $0.0 \%$ & $0.0 \%$ & $0.8 \%$ & $4.5 \%$ & $45.7 \%$ & $76.2 \%$ \\
\hline glass & 14 & - & $0.0 \%$ & $0.0 \%$ & $0.0 \%$ & $0.4 \%$ & $0.5 \%$ & $5.5 \%$ & $9.8 \%$ \\
\hline inert & 14 & - & $0.0 \%$ & $0.0 \%$ & $0.0 \%$ & $1.6 \%$ & $14.6 \%$ & $38.6 \%$ & $47.1 \%$ \\
\hline $\operatorname{mix}$ & 104 & - & $0.6 \%$ & $3.5 \%$ & $23.0 \%$ & $36.8 \%$ & $45.8 \%$ & $52.2 \%$ & $75.2 \%$ \\
\hline
\end{tabular}

Grand Total

911

$\left.{ }^{*}\right)$ number of data points

$\left.{ }^{\star *}\right)$ number of values below the detection limit 


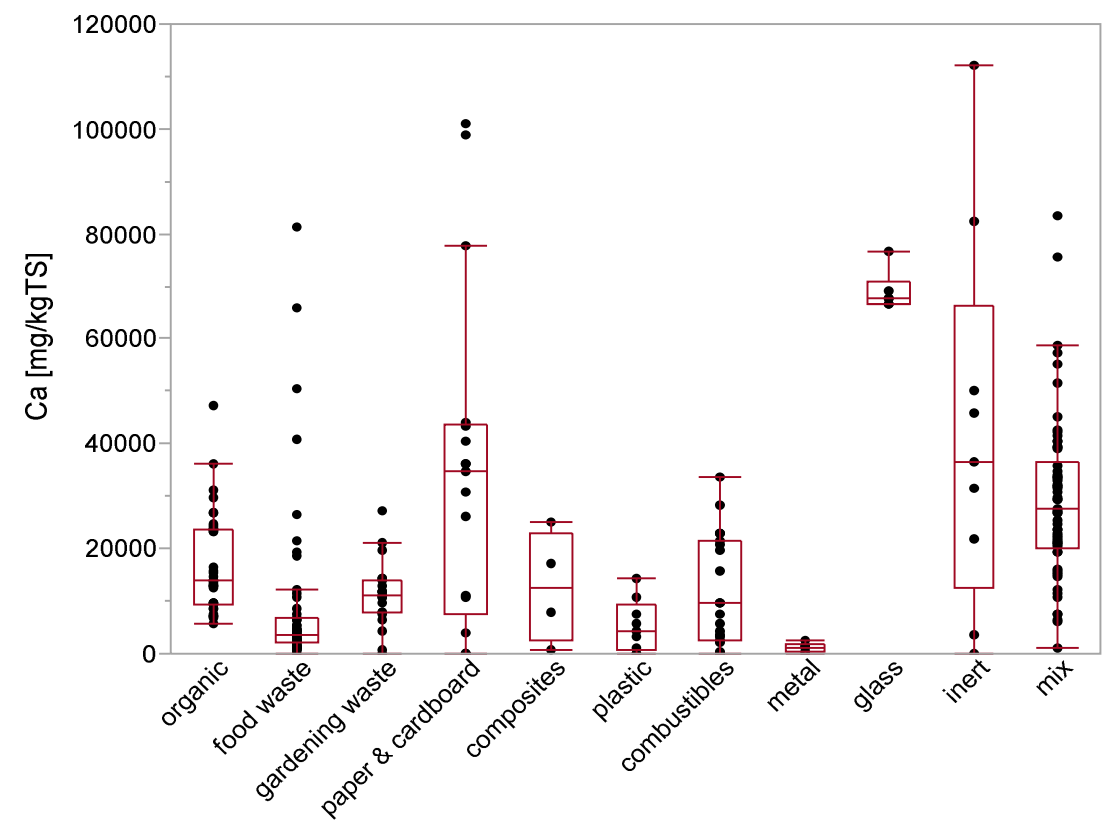

Waste Material Fractions

\section{Quantiles [mg/kgTS]}

\section{Waste Material}

\begin{tabular}{|c|c|c|c|c|c|c|c|c|c|}
\hline Fraction & n_data* & $\mathbf{n} \_<L^{* *}$ & Min & $10 \%$ & $25 \%$ & Median & $75 \%$ & $90 \%$ & Max \\
\hline organic & 38 & - & 5700 & 7180 & 9475 & 14000 & 23750 & 29850 & 47313 \\
\hline food waste & 57 & - & 0 & 1156 & 1977 & 3611 & 6709 & 22553 & 81250 \\
\hline gardening waste & 21 & - & 0 & 1306 & 7750 & 11256 & 14149 & 20838 & 27100 \\
\hline paper \& cardboard & 17 & - & 0 & 0 & 7415 & 34600 & 43600 & 99160 & 101000 \\
\hline composites & 4 & - & 727 & 727 & 2500 & 12555 & 23080 & 25010 & 25010 \\
\hline plastic & 9 & - & 21.5 & 22 & 577 & 4160 & 9270 & 14260 & 14260 \\
\hline combustibles & 23 & - & 45.7 & 51 & 2390 & 9510 & 21522 & 26140 & 33770 \\
\hline metal & 6 & - & 36 & 36 & 192 & 1143 & 1728 & 2410 & 2410 \\
\hline glass & 6 & - & 66730 & 66730 & 66783 & 67775 & 70900 & 76600 & 76600 \\
\hline inert & 9 & - & 0 & 0 & 12675 & 36400 & 66303 & 112110 & 112110 \\
\hline $\operatorname{mix}$ & 62 & - & 1228.6 & 10950 & 20075 & 27500 & 36675 & 49640 & 83550 \\
\hline
\end{tabular}

*) number of data points

$\left.{ }^{* *}\right)$ number of values below the detection limit 
Value ranges for $\mathrm{Cd}$

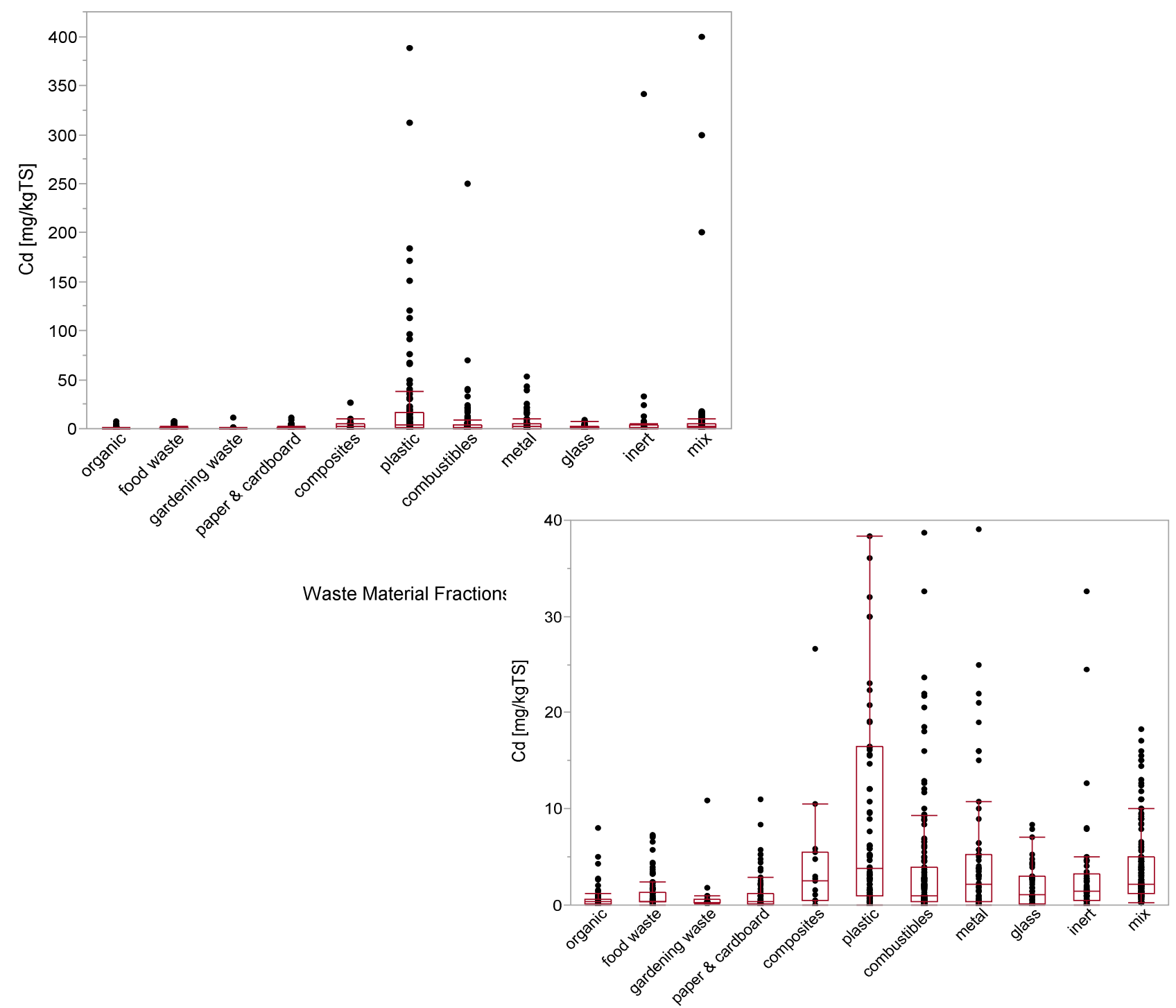

\section{Quantiles [mg/kgTS]}

\begin{tabular}{|c|c|c|c|c|c|c|c|c|c|}
\hline \multirow{2}{*}{$\begin{array}{l}\text { Waste Material } \\
\text { Fraction }\end{array}$} & \multirow[b]{2}{*}{ n_data* } & \multirow[b]{2}{*}{$\mathrm{n}_{-}<\mathrm{DL} * *$} & \multirow[b]{2}{*}{ Min } & \multicolumn{6}{|c|}{ Waste Material Fractions } \\
\hline & & & & $10 \%$ & $25 \%$ & Median & $75 \%$ & $90 \%$ & Max \\
\hline organic & 71 & 5 & 0.00 & 0.08 & 0.15 & 0.35 & 0.60 & 1.56 & 7.95 \\
\hline food waste & 100 & 42 & 0.00 & 0.10 & 0.40 & 0.40 & 1.28 & 3.49 & 7.30 \\
\hline gardening waste & 23 & - & 0.11 & 0.16 & 0.20 & 0.25 & 0.60 & 1.48 & 10.85 \\
\hline paper \& cardboard & 88 & 4 & 0.00 & 0.00 & 0.09 & 0.30 & 1.25 & 3.62 & 11.00 \\
\hline composites & 15 & - & 0.00 & 0.01 & 0.50 & 2.52 & 5.50 & 16.94 & 26.60 \\
\hline plastic & 103 & 2 & 0.00 & 0.20 & 0.90 & 3.80 & 16.50 & 72.68 & 388.00 \\
\hline combustibles & 158 & 3 & 0.00 & 0.00 & 0.30 & 1.00 & 3.93 & 11.73 & 250.00 \\
\hline metal & 71 & 5 & 0.00 & 0.00 & 0.30 & 2.10 & 5.20 & 18.40 & 53.00 \\
\hline glass & 49 & 4 & 0.00 & 0.00 & 0.15 & 1.10 & 2.95 & 4.80 & 8.40 \\
\hline inert & 50 & - & 0.00 & 0.00 & 0.50 & 1.45 & 3.28 & 7.99 & 341.00 \\
\hline $\operatorname{mix}$ & 141 & - & 0.20 & 0.76 & 1.25 & 2.17 & 5.04 & 11.67 & 400.00 \\
\hline Grand Total & 869 & 65 & & & & & & & \\
\hline
\end{tabular}


Value ranges for $\mathrm{Cl}$

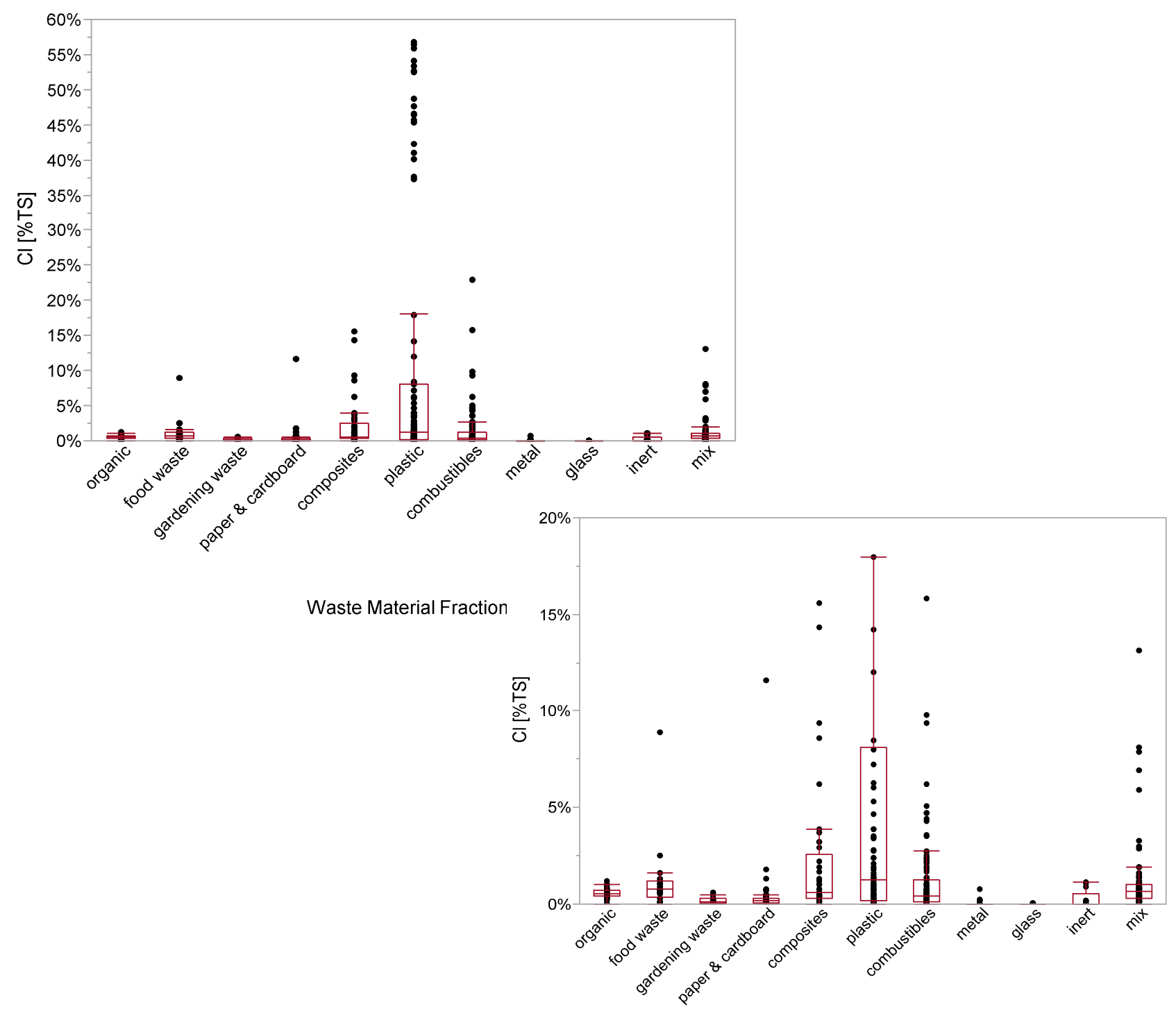

\section{Quantiles [\%TS]}

Waste Material Fractions

\section{Waste Material}

\begin{tabular}{lrrrrrrrrr}
\multicolumn{1}{c}{ Fraction } & n_data* $^{*}$ & $\mathbf{n}_{\mathbf{C}}<\mathbf{D L}^{* *}$ & Min & $\mathbf{1 0 \%}$ & $\mathbf{2 5 \%}$ & Median & $\mathbf{7 5 \%}$ & $\mathbf{9 0 \%}$ & $\mathbf{M a x}$ \\
\hline organic & 58 & - & $0.001 \%$ & $0.165 \%$ & $0.400 \%$ & $0.532 \%$ & $0.700 \%$ & $0.806 \%$ & $1.200 \%$ \\
food waste & 20 & - & $0.000 \%$ & $0.012 \%$ & $0.365 \%$ & $0.765 \%$ & $1.173 \%$ & $2.413 \%$ & $8.900 \%$ \\
gardening waste & 26 & - & $0.000 \%$ & $0.047 \%$ & $0.078 \%$ & $0.110 \%$ & $0.283 \%$ & $0.530 \%$ & $0.600 \%$ \\
paper \& cardboard & 75 & - & $0.000 \%$ & $0.001 \%$ & $0.070 \%$ & $0.160 \%$ & $0.300 \%$ & $0.500 \%$ & $11.600 \%$ \\
composites & 41 & - & $0.000 \%$ & $0.000 \%$ & $0.300 \%$ & $0.600 \%$ & $2.550 \%$ & $8.120 \%$ & $15.600 \%$ \\
plastic & 90 & - & $0.000 \%$ & $0.000 \%$ & $0.200 \%$ & $1.250 \%$ & $8.125 \%$ & $47.605 \%$ & $56.800 \%$ \\
combustibles & 114 & - & $0.000 \%$ & $0.000 \%$ & $0.100 \%$ & $0.400 \%$ & $1.248 \%$ & $3.550 \%$ & $23.000 \%$ \\
metal & 19 & - & $0.000 \%$ & $0.000 \%$ & $0.000 \%$ & $0.000 \%$ & $0.001 \%$ & $0.240 \%$ & $0.760 \%$ \\
glass & 10 & - & $0.000 \%$ & $0.000 \%$ & $0.000 \%$ & $0.000 \%$ & $0.000 \%$ & $0.054 \%$ & $0.060 \%$ \\
inert & 13 & - & $0.000 \%$ & $0.000 \%$ & $0.000 \%$ & $0.020 \%$ & $0.550 \%$ & $1.094 \%$ & $1.110 \%$ \\
mix & 81 & - & $0.000 \%$ & $0.104 \%$ & $0.305 \%$ & $0.670 \%$ & $1.000 \%$ & $2.692 \%$ & $13.160 \%$ \\
\hline Total & 547 & 0 & & & & & & &
\end{tabular}

*) number of data points

$\left.{ }^{\star *}\right)$ number of values below the detection limit 
Value ranges for Co

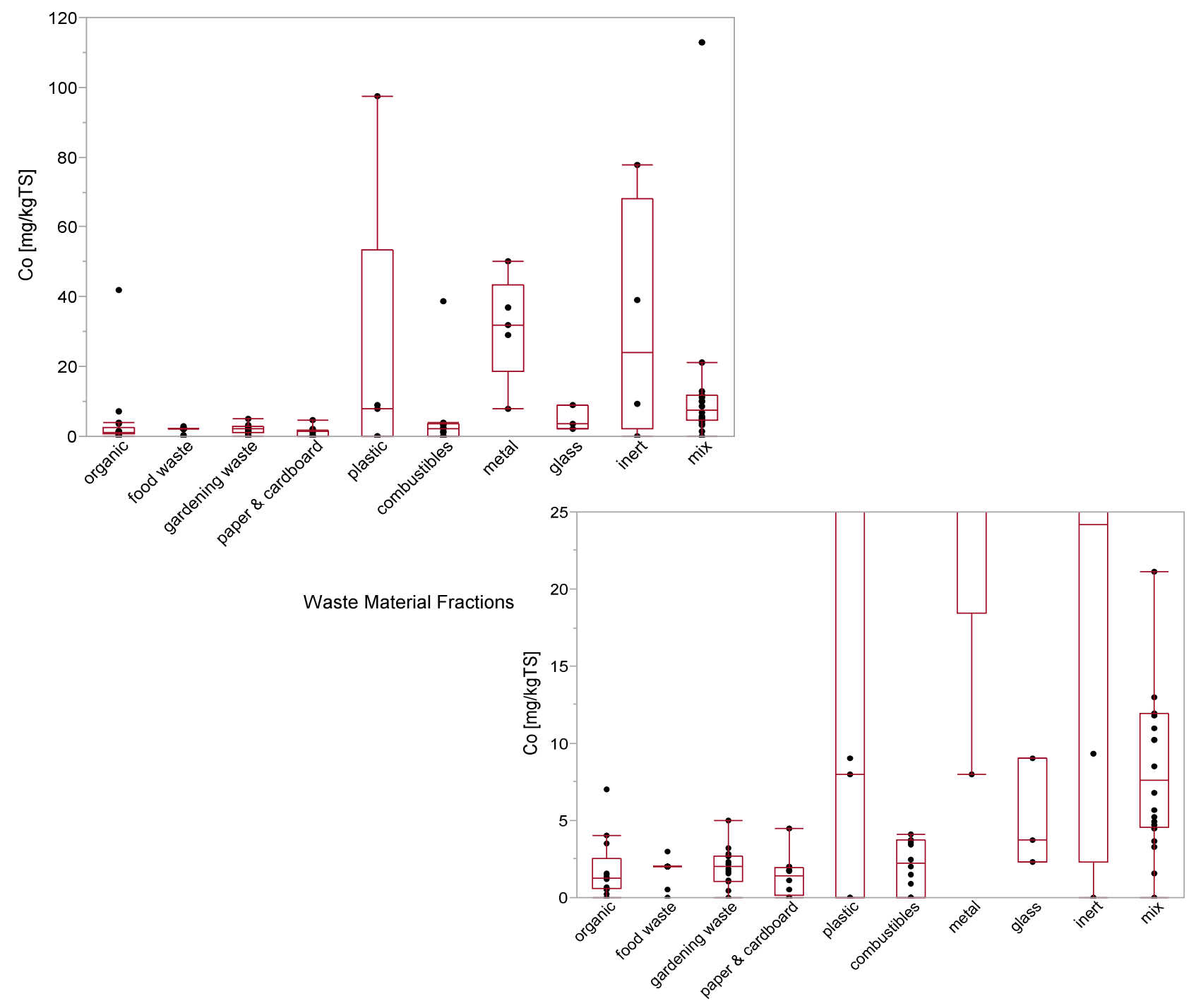

Quantiles [mg/kgTS]

Waste Material Fractions

\begin{tabular}{|c|c|c|c|c|c|c|c|c|c|}
\hline $\begin{array}{l}\text { Waste Material } \\
\text { Fraction }\end{array}$ & n_data* & $n \_<L^{* *}$ & Min & $10 \%$ & $25 \%$ & Median & $75 \%$ & $90 \%$ & Max \\
\hline organic & 17 & 1 & 0.0 & 0.2 & 0.6 & 1.3 & 2.6 & 14.0 & 42.0 \\
\hline food waste & 43 & 41 & 0.0 & 2.0 & 2.0 & 2.0 & 2.0 & 2.0 & 3.0 \\
\hline gardening waste & 14 & - & 0.0 & 0.2 & 1.1 & 2.0 & 2.7 & 4.1 & 5.0 \\
\hline paper \& cardboard & 8 & 1 & 0.0 & 0.0 & 0.1 & 1.4 & 2.0 & 4.5 & 4.5 \\
\hline composites & - & - & - & - & - & - & - & - & - \\
\hline plastic & 5 & - & 0.0 & 0.0 & 0.0 & 8.0 & 53.3 & 97.6 & 97.6 \\
\hline combustibles & 14 & - & 0.0 & 0.0 & 0.0 & 2.3 & 3.7 & 21.4 & 38.7 \\
\hline metal & 5 & - & 8.0 & 8.0 & 18.5 & 32.0 & 43.5 & 50.0 & 50.0 \\
\hline glass & 3 & - & 2.3 & 2.3 & 2.3 & 3.7 & 9.0 & 9.0 & 9.0 \\
\hline inert & 4 & - & 0.0 & 0.0 & 2.3 & 24.2 & 68.0 & 77.7 & 77.7 \\
\hline $\operatorname{mix}$ & 20 & - & 0.0 & 1.8 & 4.5 & 7.6 & 11.9 & 103.8 & 113.0 \\
\hline
\end{tabular}

*) number of data points

${ }^{* *}$ ) number of values below the detection limit 


\section{Value ranges for $\mathrm{Cr}$}

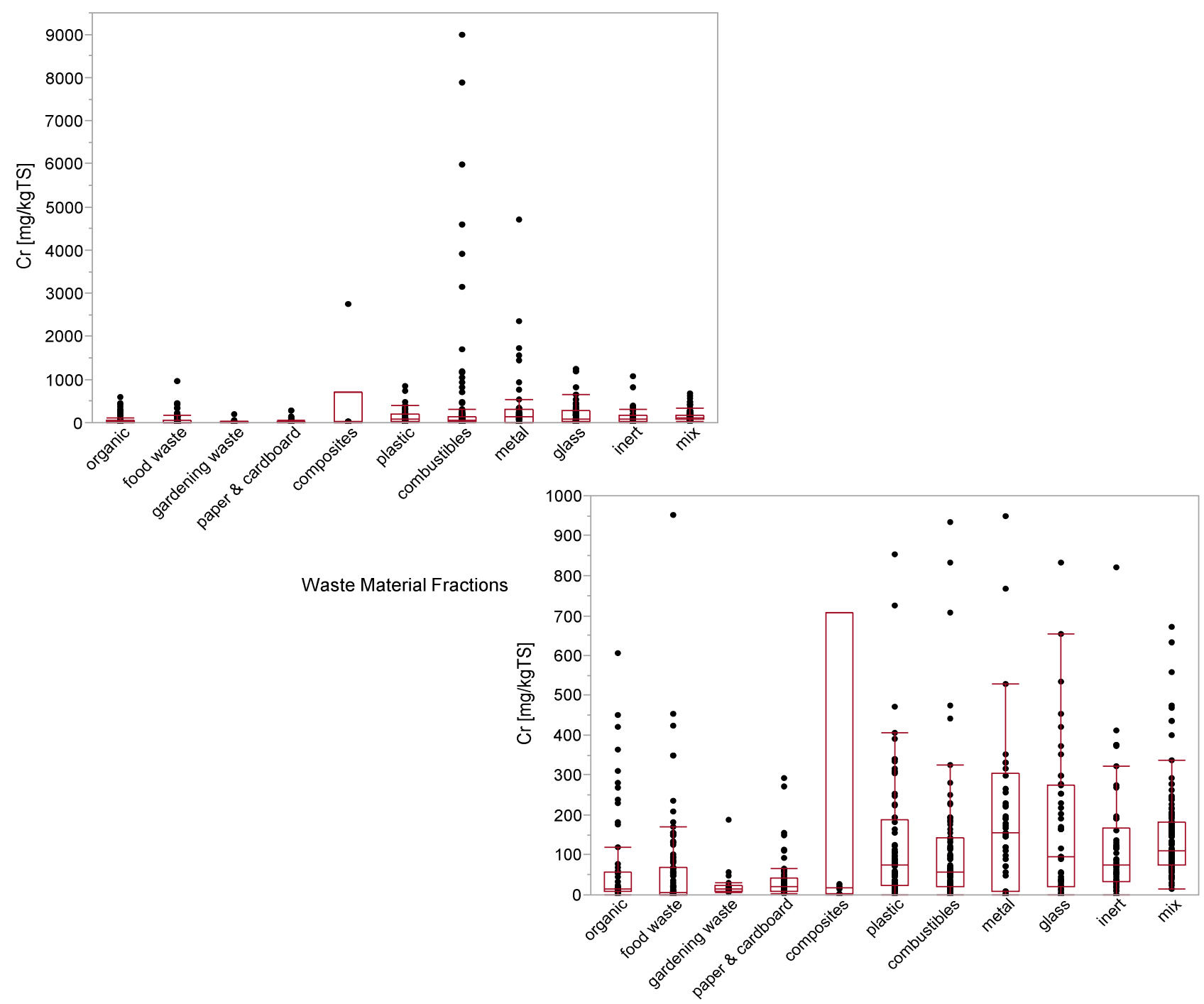

\section{Quantiles [mg/kgTS]}

Waste Material Fractions

\begin{tabular}{|c|c|c|c|c|c|c|c|c|c|}
\hline $\begin{array}{c}\text { Waste Material } \\
\text { Fraction }\end{array}$ & n_data* & $n_{-}<D L^{* *}$ & Min & $10 \%$ & $25 \%$ & Median & $75 \%$ & $90 \%$ & Max \\
\hline organic & 62 & - & 1.3 & 6.2 & 8.4 & 14.8 & 56.3 & 277.0 & 607.0 \\
\hline food waste & 103 & 17 & 0.0 & 1.0 & 1.1 & 5.2 & 69.0 & 155.3 & 951.5 \\
\hline gardening waste & 19 & 1 & 4.5 & 8.0 & 8.7 & 16.2 & 23.0 & 55.5 & 188.7 \\
\hline paper \& cardboard & 65 & - & 2.5 & 5.4 & 8.8 & 20.0 & 40.3 & 99.4 & 291.8 \\
\hline composites & 6 & - & 1.0 & 1.0 & 2.4 & 18.5 & 708.5 & 2750.0 & 2750.0 \\
\hline plastic & 73 & - & 0.4 & 9.7 & 25.4 & 73.9 & 187.0 & 338.4 & 853.0 \\
\hline combustibles & 122 & - & 0.0 & 6.2 & 19.8 & 56.4 & 142.2 & 795.3 & 9000.0 \\
\hline metal & 50 & - & 0.0 & 0.0 & 9.2 & 154.5 & 304.3 & 1387.0 & 4702.0 \\
\hline glass & 49 & - & 0.0 & 0.0 & 21.6 & 95.3 & 275.7 & 534.0 & 1236.8 \\
\hline inert & 50 & - & 0.0 & 13.4 & 34.0 & 74.3 & 167.5 & 377.1 & 1075.5 \\
\hline $\operatorname{mix}$ & 116 & - & 16.0 & 53.0 & 74.8 & 111.8 & 182.3 & 277.1 & 671.1 \\
\hline
\end{tabular}

\begin{tabular}{lll}
\hline Grand Total & 715 & 18
\end{tabular}

*) number of data points

${ }^{* *}$ ) number of values below the detection limit 


\section{Value ranges for $\mathrm{Cu}$}

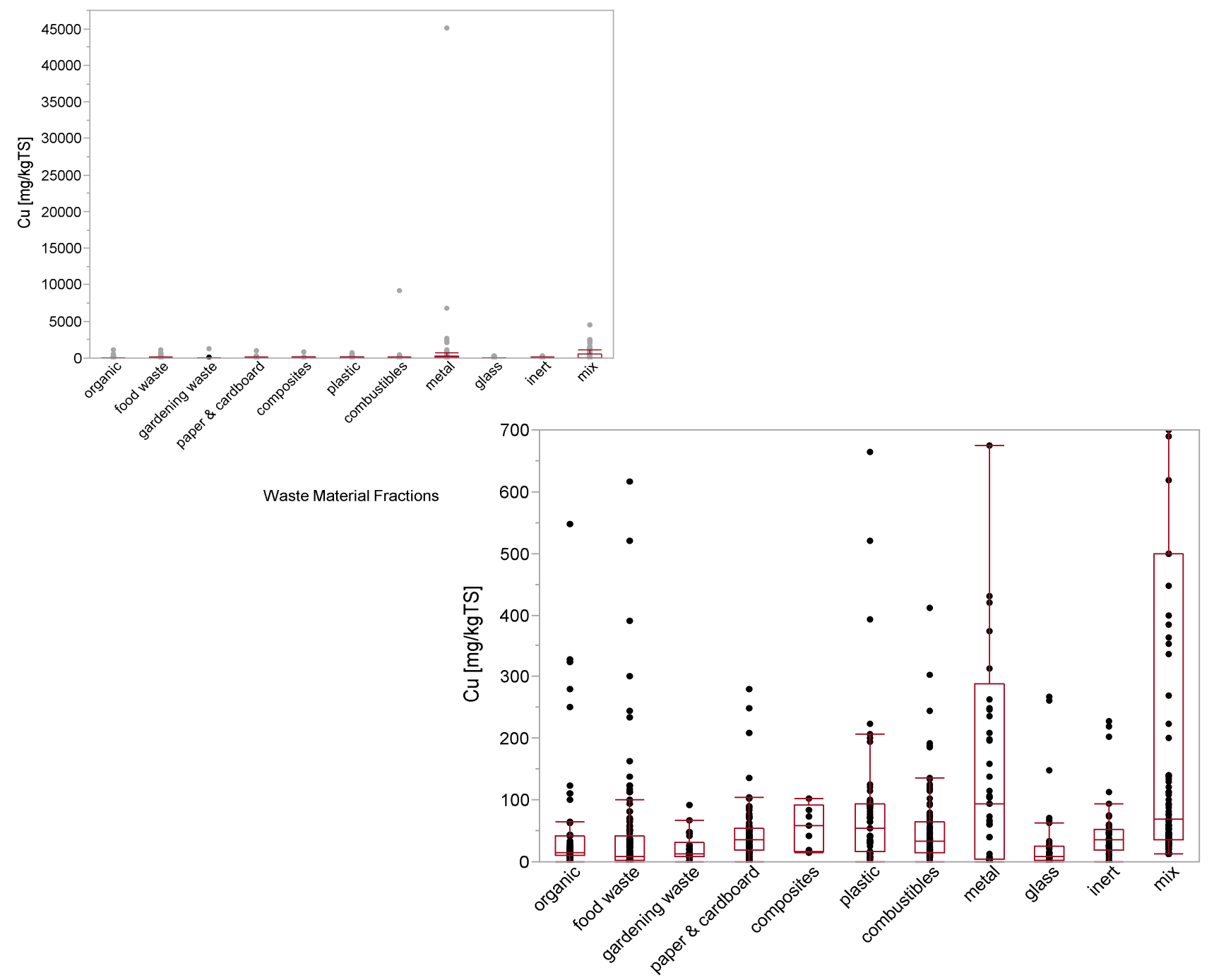

\section{Quantiles [mg/kgTS]}

Waste Material Fractions

\begin{tabular}{|c|c|c|c|c|c|c|c|c|c|}
\hline $\begin{array}{l}\text { Waste Material } \\
\text { Fraction }\end{array}$ & n_data* & $\mathrm{n}_{-}<\mathrm{DL} * *$ & Min & $10 \%$ & $25 \%$ & Median & $75 \%$ & $90 \%$ & Max \\
\hline organic & 59 & - & 0.00 & 7.22 & 10.20 & 15.10 & 41.45 & 250.00 & 1196.59 \\
\hline food waste & 117 & 40 & 0.00 & 2.00 & 2.00 & 9.00 & 42.00 & 126.82 & 1168.20 \\
\hline gardening waste & 30 & - & 0.18 & 0.60 & 7.93 & 13.11 & 31.25 & 64.30 & 1238.61 \\
\hline paper \& cardboard & 72 & - & 0.00 & 7.86 & 17.78 & 34.76 & 55.20 & 98.49 & 1019.60 \\
\hline composites & 9 & - & 14.00 & 14.00 & 17.05 & 59.40 & 92.55 & 834.00 & 834.00 \\
\hline plastic & 57 & - & 0.00 & 8.24 & 16.85 & 54.20 & 93.85 & 201.20 & 665.30 \\
\hline combustibles & 112 & - & 0.00 & 8.79 & 14.35 & 33.60 & 65.35 & 131.93 & 9240.00 \\
\hline metal & 53 & 1 & 0.00 & 0.00 & 4.55 & 94.50 & 288.60 & 1691.20 & 45100.00 \\
\hline glass & 42 & - & 0.00 & 0.00 & 1.85 & 8.50 & 26.00 & 69.64 & 267.50 \\
\hline inert & 46 & - & 0.00 & 0.56 & 18.58 & 35.80 & 51.70 & 99.70 & 227.00 \\
\hline $\operatorname{mix}$ & 110 & - & 12.17 & 19.61 & 35.21 & 67.93 & 500.00 & 1154.99 & 4500.00 \\
\hline Grand Total & 707 & 41 & & & & & & & \\
\hline
\end{tabular}

*) number of data points

${ }^{* *}$ ) number of values below the detection limit 
Value ranges for $F$

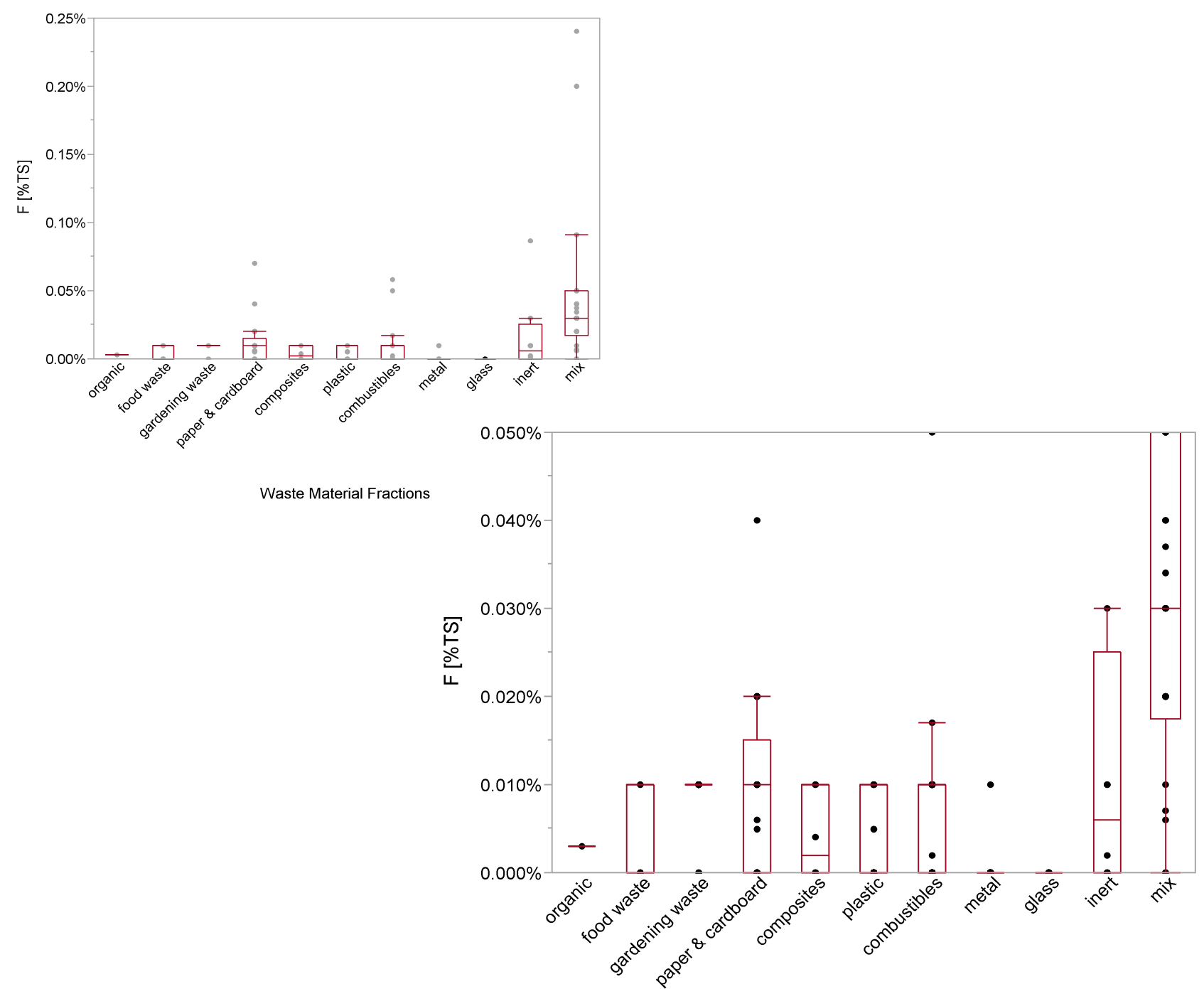

Quantiles [\%TS]

Waste Material Fractions

Waste Material

\begin{tabular}{lrrrrrrrrr}
\multicolumn{1}{c}{ Fraction } & $\mathbf{n}$ data*$^{*}$ & $\mathbf{n}<$ DL** $^{*}$ & Min & $\mathbf{1 0 \%}$ & $\mathbf{2 5 \%}$ & Median & $\mathbf{7 5 \%}$ & $\mathbf{9 0 \%}$ & $\mathbf{M a x}$ \\
\hline organic & - & - & - & - & - & - & - & - & - \\
food waste & 5 & - & $0.000 \%$ & $0.000 \%$ & $0.000 \%$ & $0.000 \%$ & $0.010 \%$ & $0.010 \%$ & $0.010 \%$ \\
gardening waste & 16 & 12 & $0.000 \%$ & $0.000 \%$ & $0.010 \%$ & $0.010 \%$ & $0.010 \%$ & $0.010 \%$ & $0.010 \%$ \\
paper \& cardboard & 21 & - & $0.000 \%$ & $0.000 \%$ & $0.000 \%$ & $0.010 \%$ & $0.015 \%$ & $0.036 \%$ & $0.070 \%$ \\
composites & 6 & - & $0.000 \%$ & $0.000 \%$ & $0.000 \%$ & $0.002 \%$ & $0.010 \%$ & $0.010 \%$ & $0.010 \%$ \\
plastic & 14 & - & $0.000 \%$ & $0.000 \%$ & $0.000 \%$ & $0.000 \%$ & $0.010 \%$ & $0.010 \%$ & $0.010 \%$ \\
combustibles & 25 & - & $0.000 \%$ & $0.000 \%$ & $0.000 \%$ & $0.010 \%$ & $0.010 \%$ & $0.030 \%$ & $0.058 \%$ \\
metal & 17 & - & $0.000 \%$ & $0.000 \%$ & $0.000 \%$ & $0.000 \%$ & $0.000 \%$ & $0.002 \%$ & $0.010 \%$ \\
glass & 6 & - & $0.000 \%$ & $0.000 \%$ & $0.000 \%$ & $0.000 \%$ & $0.000 \%$ & $0.000 \%$ & $0.000 \%$ \\
inert & 8 & - & $0.000 \%$ & $0.000 \%$ & $0.000 \%$ & $0.006 \%$ & $0.025 \%$ & $0.087 \%$ & $0.087 \%$ \\
mix & 22 & - & $0.000 \%$ & $0.002 \%$ & $0.018 \%$ & $0.030 \%$ & $0.050 \%$ & $0.200 \%$ & $0.240 \%$ \\
\hline Total & 140 & 12 & & & & & & &
\end{tabular}

$\left.{ }^{*}\right)$ number of data points

$\left.{ }^{\star *}\right)$ number of values below the detection limit 


\section{Value ranges for $\mathrm{Fe}$}

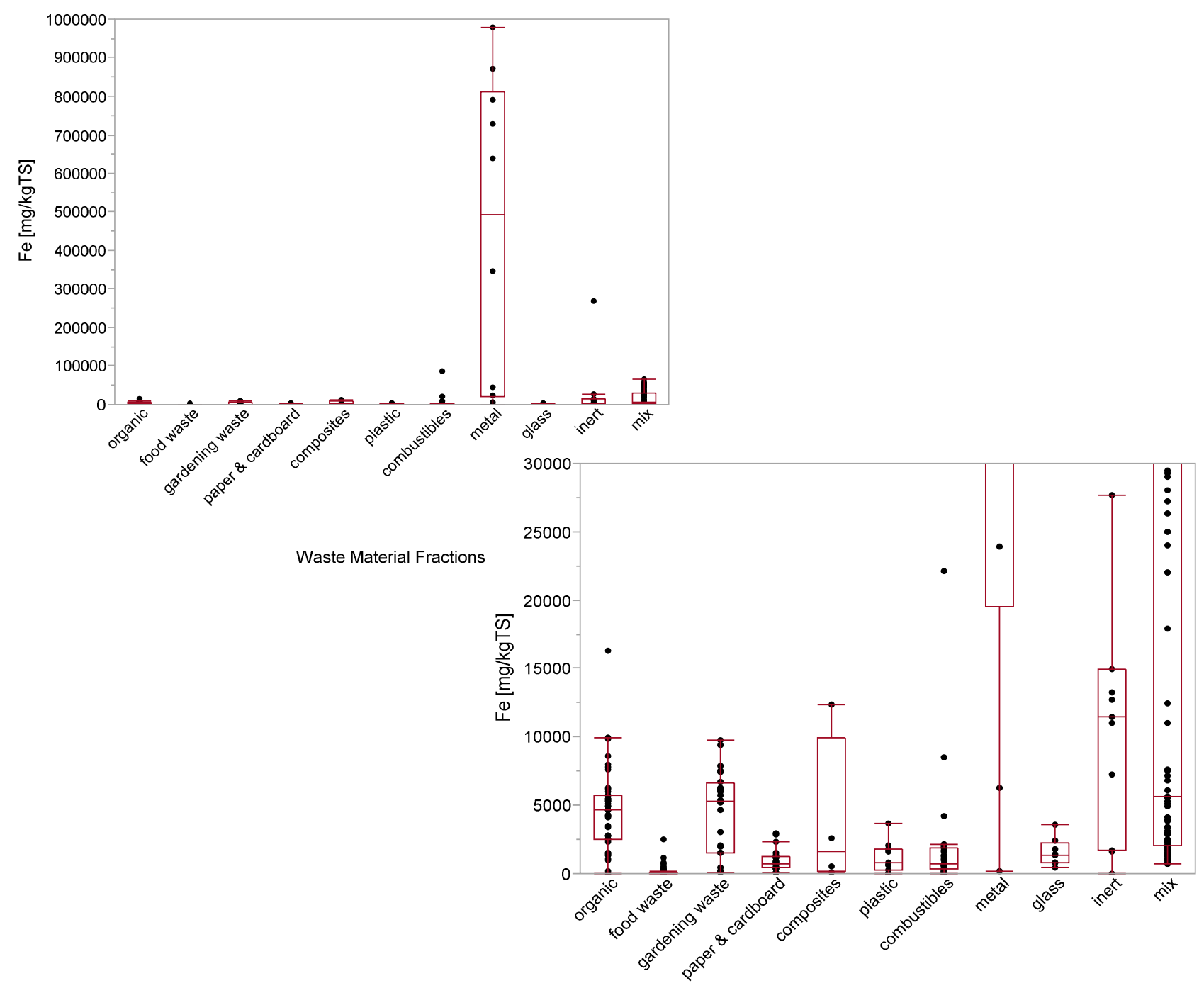

\section{Quantiles [mg/kgTS]}

Waste Material Fractions

\begin{tabular}{|c|c|c|c|c|c|c|c|c|c|}
\hline $\begin{array}{l}\text { Waste Material } \\
\text { Fraction }\end{array}$ & n_data* & $n \_<L^{* *}$ & Min & $10 \%$ & $25 \%$ & Median & $75 \%$ & $90 \%$ & Max \\
\hline organic & 45 & - & 0 & 1220 & 2500 & 4700 & 5700 & 8240 & 16333 \\
\hline food waste & 64 & - & 0 & 18 & 29 & 48 & 88 & 409 & 2478 \\
\hline gardening waste & 24 & - & 76 & 168 & 1485 & 5270 & 6600 & 8643 & 9728 \\
\hline paper \& cardboard & 22 & - & 46 & 147 & 459 & 755 & 1245 & 2722 & 2940 \\
\hline composites & 4 & - & 86 & 86 & 199 & 1585 & 9898 & 12320 & 12320 \\
\hline plastic & 11 & - & 0 & 0 & 305 & 849 & 1830 & 3380 & 3700 \\
\hline combustibles & 31 & - & 0 & 9 & 340 & 733 & 1850 & 7634 & 85100 \\
\hline metal & 10 & - & 150 & 765 & 19500 & 492500 & 810750 & 969300 & 980000 \\
\hline glass & 8 & - & 477 & 477 & 777 & 1350 & 2240 & 3567 & 3567 \\
\hline inert & 11 & - & 0 & 320 & 1730 & 11500 & 14990 & 219940 & 268000 \\
\hline $\operatorname{mix}$ & 82 & - & 684 & 1299 & 2017 & 5605 & 30819 & 49137 & 66000 \\
\hline
\end{tabular}

*) number of data points

${ }^{\star *}$ ) number of values below the detection limit 


\section{Value ranges for $\mathrm{H}$}

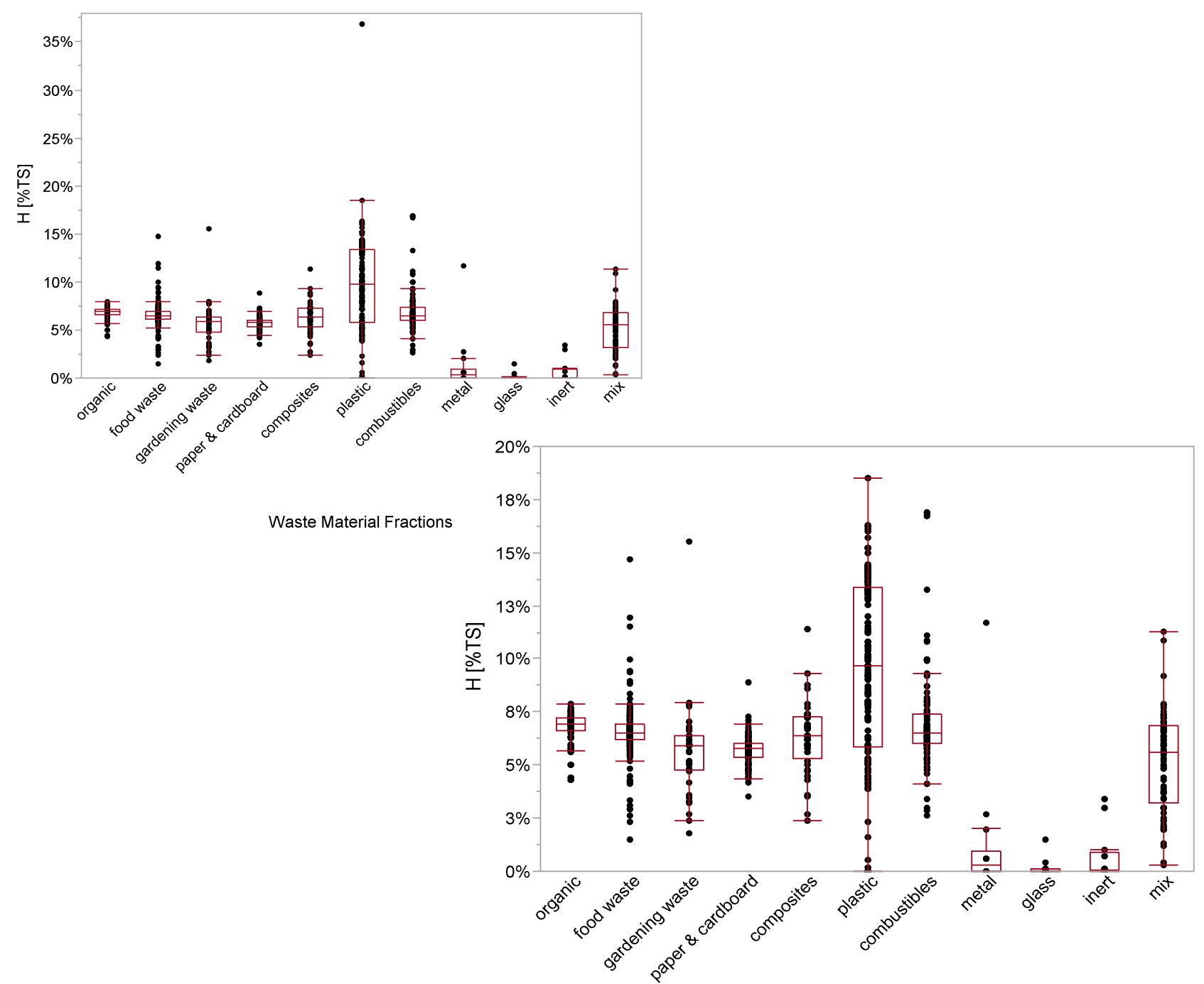

Quantiles [\%TS]

Waste Material Fractions

Waste Material

\begin{tabular}{lrrrrrrrrr}
\multicolumn{1}{c}{ Fraction } & $\mathbf{n} \mathbf{d a t a}^{*}$ & $\mathbf{n}<\mathbf{D L}^{* *}$ & \multicolumn{1}{c}{ Min } & $\mathbf{1 0} \%$ & $\mathbf{2 5 \%}$ & Median & $\mathbf{7 5 \%}$ & \multicolumn{9}{c}{$\mathbf{9 0 \%}$} & \multicolumn{1}{c}{ Max } \\
\hline organic & 59 & - & $4.3 \%$ & $5.7 \%$ & $6.6 \%$ & $6.9 \%$ & $7.2 \%$ & $7.5 \%$ & $7.9 \%$ \\
food waste & 173 & - & $1.5 \%$ & $5.5 \%$ & $6.2 \%$ & $6.5 \%$ & $6.9 \%$ & $7.6 \%$ & $14.7 \%$ \\
gardening waste & 40 & - & $1.8 \%$ & $3.2 \%$ & $4.8 \%$ & $5.9 \%$ & $6.4 \%$ & $7.7 \%$ & $15.5 \%$ \\
paper \& cardboard & 112 & - & $3.5 \%$ & $4.8 \%$ & $5.4 \%$ & $5.8 \%$ & $6.0 \%$ & $6.4 \%$ & $8.9 \%$ \\
composites & 40 & - & $2.4 \%$ & $3.7 \%$ & $5.3 \%$ & $6.4 \%$ & $7.3 \%$ & $8.5 \%$ & $11.4 \%$ \\
plastic & 151 & - & $0.0 \%$ & $3.9 \%$ & $5.8 \%$ & $9.7 \%$ & $13.4 \%$ & $14.4 \%$ & $36.9 \%$ \\
combustibles & 138 & - & $2.6 \%$ & $5.3 \%$ & $6.0 \%$ & $6.5 \%$ & $7.4 \%$ & $9.3 \%$ & $16.9 \%$ \\
metal & 14 & - & $0.0 \%$ & $0.0 \%$ & $0.0 \%$ & $0.3 \%$ & $1.0 \%$ & $7.2 \%$ & $11.7 \%$ \\
glass & 13 & 1 & $0.0 \%$ & $0.0 \%$ & $0.0 \%$ & $0.0 \%$ & $0.1 \%$ & $1.1 \%$ & $1.5 \%$ \\
inert & 12 & - & $0.0 \%$ & $0.0 \%$ & $0.0 \%$ & $0.1 \%$ & $0.9 \%$ & $3.3 \%$ & $3.4 \%$ \\
mix & 73 & - & $0.3 \%$ & $2.0 \%$ & $3.2 \%$ & $5.6 \%$ & $6.8 \%$ & $7.5 \%$ & $11.3 \%$ \\
\hline Grand Total & 825 & 1 & & & & & & &
\end{tabular}

*) number of data points

${ }^{* *}$ ) number of values below the detection limit 
Value ranges for $\mathrm{Hg}$

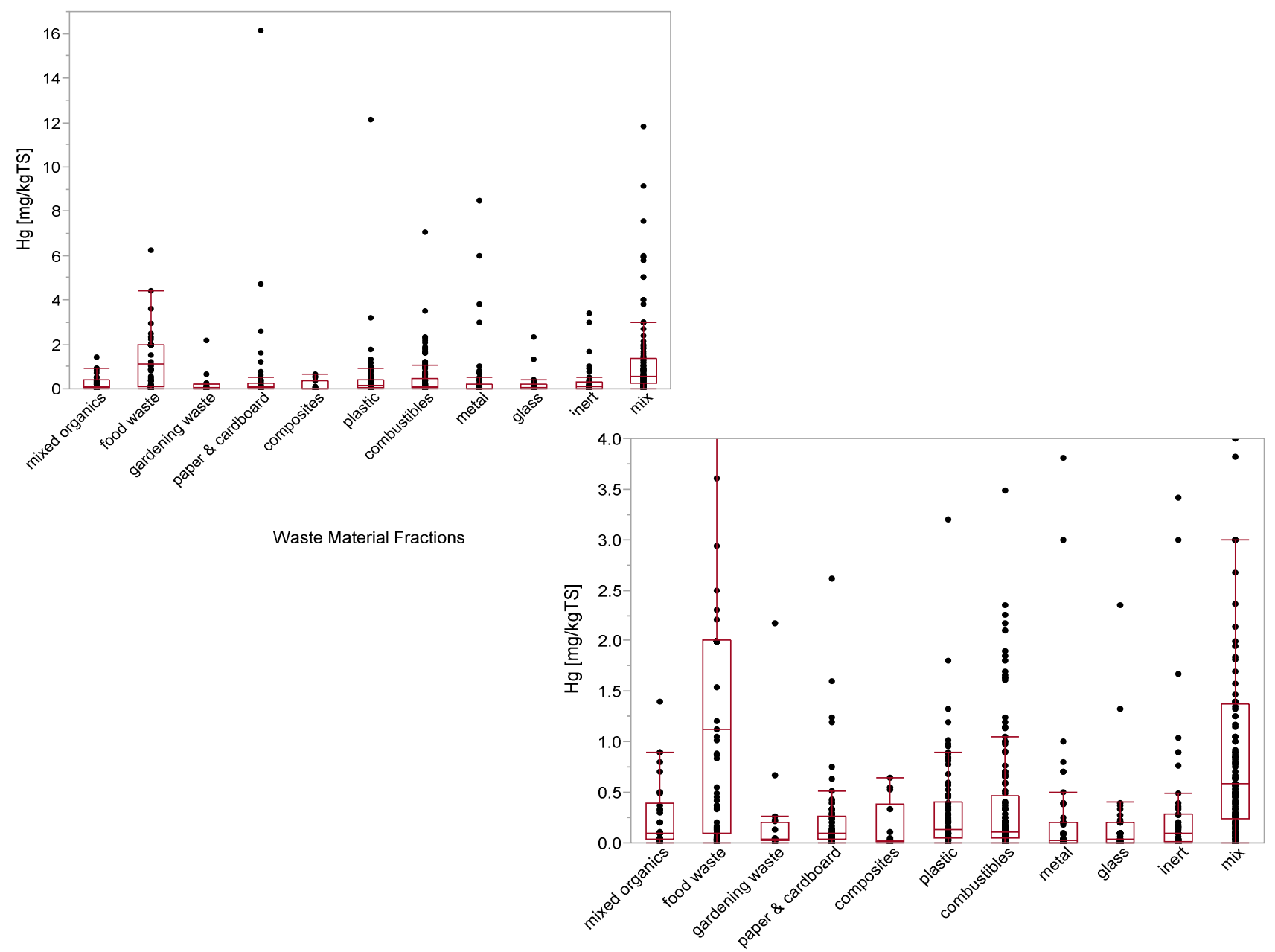

Quantiles [mg/kgTS]

\begin{tabular}{|c|c|c|c|c|c|c|c|c|c|}
\hline \multirow{2}{*}{$\begin{array}{l}\text { Waste Material } \\
\text { Fraction }\end{array}$} & \multirow[b]{2}{*}{ n_data* } & \multirow[b]{2}{*}{$\mathrm{n}_{-}<\mathrm{DL} \mathbf{L}^{\star *}$} & \multirow[b]{2}{*}{ Min } & \multirow[b]{2}{*}{$10 \%$} & \multicolumn{4}{|c|}{ Waste Material Fractions } & \multirow[b]{2}{*}{$\operatorname{Max}$} \\
\hline & & & & & $25 \%$ & Median & $75 \%$ & $90 \%$ & \\
\hline organic & 34 & 4 & 0.000 & 0.020 & 0.040 & 0.100 & 0.396 & 0.850 & 1.400 \\
\hline food waste & 99 & 41 & 0.000 & 0.020 & 0.100 & 1.120 & 2.000 & 2.000 & 6.250 \\
\hline food waste -alt ${ }^{\star \star \star}$ & 59 & 1 & 0.000 & 0.000 & 0.040 & 0.140 & 0.870 & 2.310 & 6.250 \\
\hline gardening waste & 20 & 3 & 0.000 & 0.020 & 0.023 & 0.040 & 0.198 & 0.629 & 2.170 \\
\hline paper \& cardboard & 84 & 6 & 0.000 & 0.000 & 0.030 & 0.098 & 0.265 & 0.570 & 16.160 \\
\hline composites & 14 & - & 0.000 & 0.000 & 0.008 & 0.025 & 0.380 & 0.595 & 0.640 \\
\hline plastic & 89 & 3 & 0.000 & 0.000 & 0.045 & 0.130 & 0.400 & 0.891 & 12.150 \\
\hline combustibles & 140 & 6 & 0.000 & 0.000 & 0.050 & 0.110 & 0.470 & 1.573 & 7.030 \\
\hline metal & 60 & 5 & 0.000 & 0.000 & 0.000 & 0.025 & 0.200 & 0.790 & 8.500 \\
\hline glass & 49 & 6 & 0.000 & 0.000 & 0.000 & 0.040 & 0.200 & 0.340 & 2.350 \\
\hline inert & 49 & 5 & 0.000 & 0.000 & 0.015 & 0.100 & 0.285 & 0.900 & 3.420 \\
\hline $\operatorname{mix}$ & 113 & - & 0.000 & 0.070 & 0.235 & 0.580 & 1.375 & 3.928 & 11.800 \\
\hline
\end{tabular}

Grand Total

$\left.{ }^{*}\right)$ number of data points

${ }^{* *}$ ) number of values below the detection limit

${ }^{* \star *}$ ) alternativ calculation excluding 55 data points from Wrap 2010, which were all below the same detection limit 


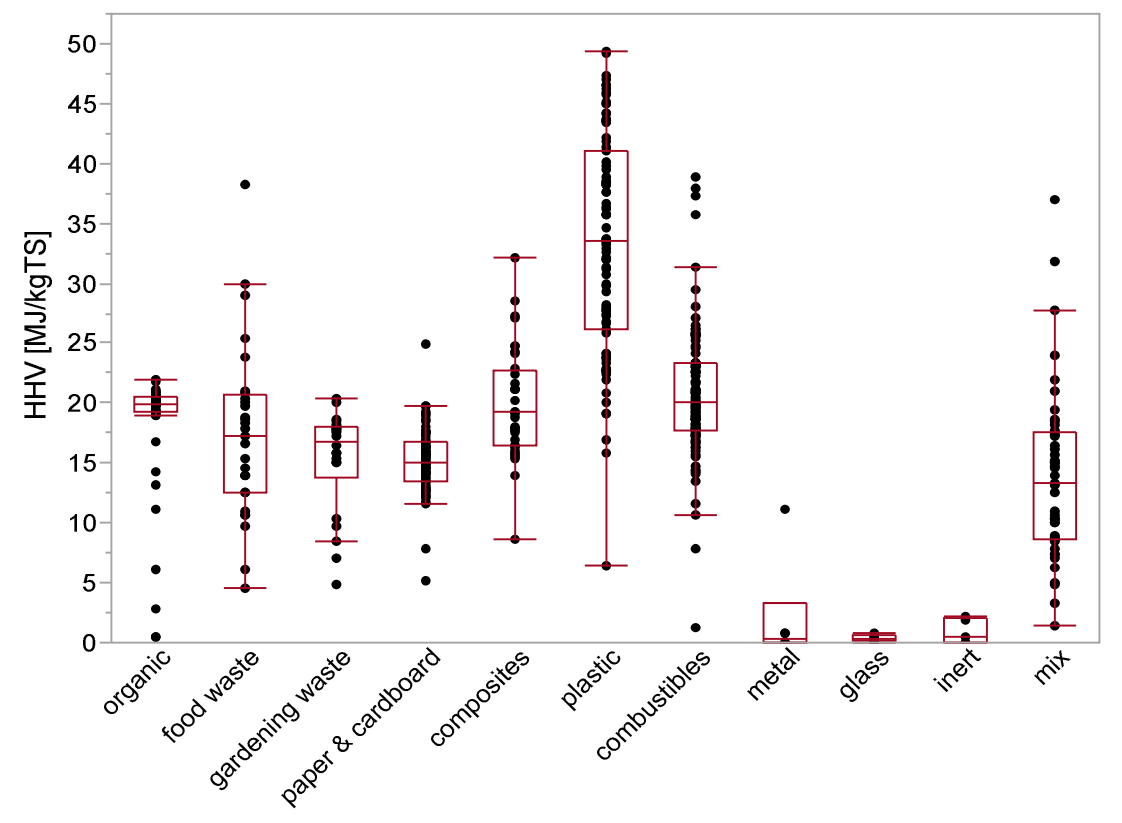

Waste Material Fractions

\section{Quantiles [MJ/kgTS]}

\begin{tabular}{|c|c|c|c|c|c|c|c|c|c|}
\hline $\begin{array}{c}\text { Waste Material } \\
\text { Fraction }\end{array}$ & n_data* & $\mathrm{n}_{-}<\mathrm{DL}$ ** & Min & $10 \%$ & $25 \%$ & Median & $75 \%$ & $90 \%$ & Max \\
\hline organic & 55 & 2 & 0.5 & 12.4 & 19.2 & 20.0 & 20.6 & 21.0 & 22.0 \\
\hline food waste & 29 & - & 4.6 & 9.6 & 12.5 & 17.3 & 20.6 & 29.0 & 38.3 \\
\hline gardening waste & 22 & - & 4.8 & 7.4 & 13.9 & 16.8 & 18.0 & 19.6 & 20.4 \\
\hline paper \& cardboard & 79 & - & 5.2 & 12.4 & 13.6 & 15.1 & 16.7 & 18.5 & 24.9 \\
\hline composites & 36 & - & 8.6 & 15.4 & 16.4 & 19.2 & 22.8 & 27.2 & 32.2 \\
\hline plastic & 91 & - & 6.5 & 22.4 & 26.1 & 33.5 & 41.0 & 45.7 & 49.4 \\
\hline combustibles & 100 & - & 1.3 & 15.5 & 17.7 & 20.0 & 23.3 & 26.2 & 38.9 \\
\hline metal & 6 & - & 0.0 & 0.0 & 0.0 & 0.4 & 3.3 & 11.1 & 11.1 \\
\hline glass & 6 & 2 & 0.0 & 0.0 & 0.1 & 0.4 & 0.6 & 0.8 & 0.8 \\
\hline inert & 5 & 1 & 0.0 & 0.0 & 0.0 & 0.5 & 2.0 & 2.2 & 2.2 \\
\hline $\operatorname{mix}$ & 45 & - & 1.4 & 5.8 & 8.6 & 13.4 & 17.5 & 22.8 & 37.0 \\
\hline
\end{tabular}

*) number of data points

${ }^{* *}$ ) number of values below the detection limit 


\section{Value ranges for $K$}

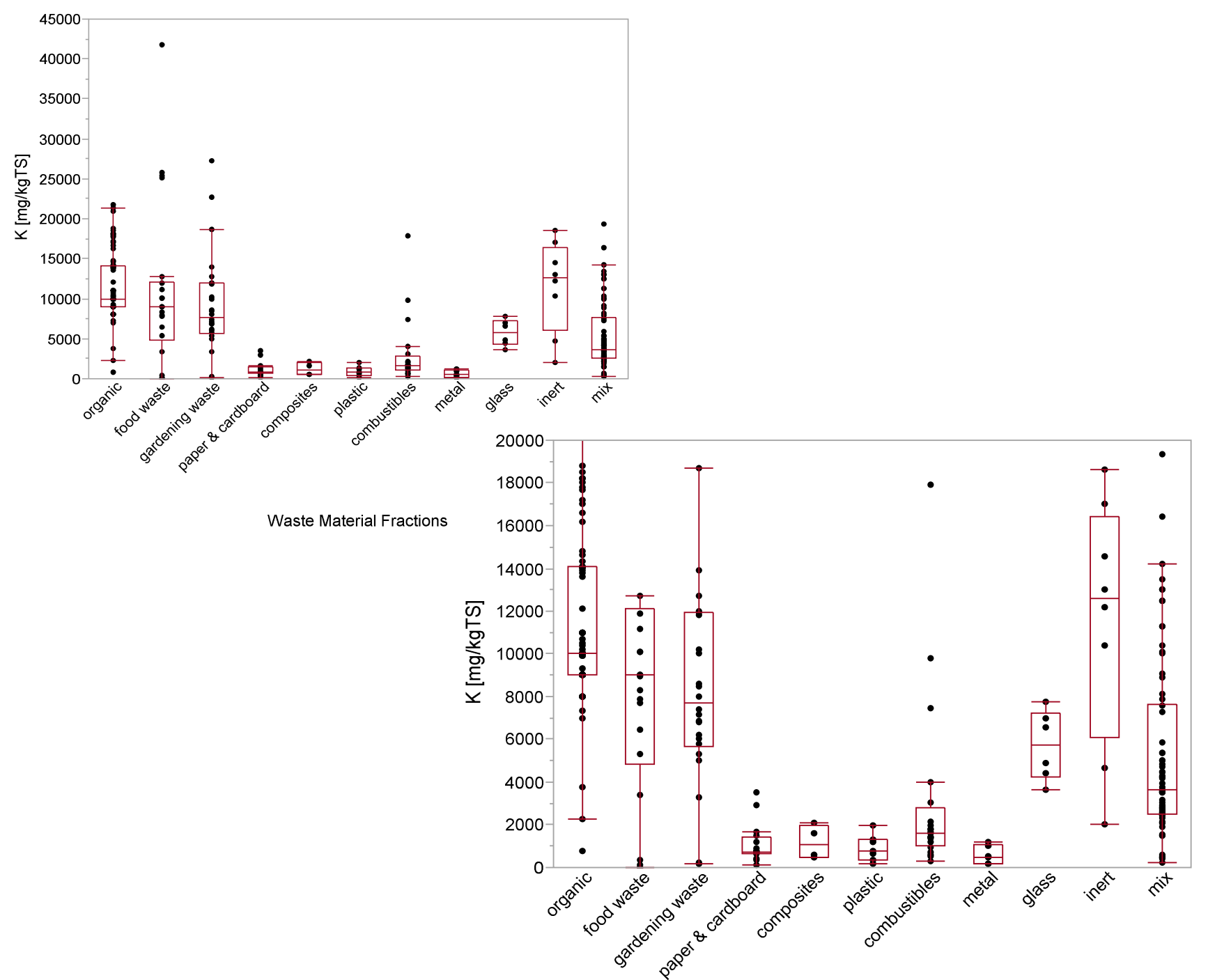

\section{Quantiles [mg/kgTS]}

Waste Material Fractions

\begin{tabular}{|c|c|c|c|c|c|c|c|c|c|}
\hline $\begin{array}{l}\text { Waste Material } \\
\text { Fraction }\end{array}$ & n_data* & $\mathrm{n}_{-}<\mathrm{DL}$ ** & Min & $10 \%$ & $25 \%$ & Median & $75 \%$ & $90 \%$ & Max \\
\hline organic & 76 & - & 795 & 8000 & 9000 & 10000 & 14075 & 18060 & 21700 \\
\hline food waste & 22 & - & 0 & 34 & 4850 & 8989 & 12100 & 25693 & 41800 \\
\hline gardening waste & 26 & - & 161 & 216 & 5677 & 7695 & 11960 & 19900 & 27300 \\
\hline paper \& cardboard & 16 & - & 118 & 297 & 676 & 743 & 1430 & 3080 & 3500 \\
\hline composites & 4 & - & 472 & 472 & 497 & 1096 & 1980 & 2100 & 2100 \\
\hline plastic & 7 & - & 190 & 190 & 372 & 750 & 1300 & 1990 & 1990 \\
\hline combustibles & 20 & - & 278 & 564 & 1016 & 1640 & 2803 & 9565 & 17900 \\
\hline metal & 6 & - & 162 & 162 & 191 & 501 & 1045 & 1190 & 1190 \\
\hline glass & 6 & - & 3650 & 3650 & 4237 & 5730 & 7195 & 7750 & 7750 \\
\hline inert & 8 & - & 2010 & 2010 & 6110 & 12600 & 16408 & 18600 & 18600 \\
\hline $\operatorname{mix}$ & 70 & - & 249 & 1484 & 2500 & 3622 & 7638 & 12497 & 19339 \\
\hline
\end{tabular}

*) number of data points

${ }^{* *}$ ) number of values below the detection limit 


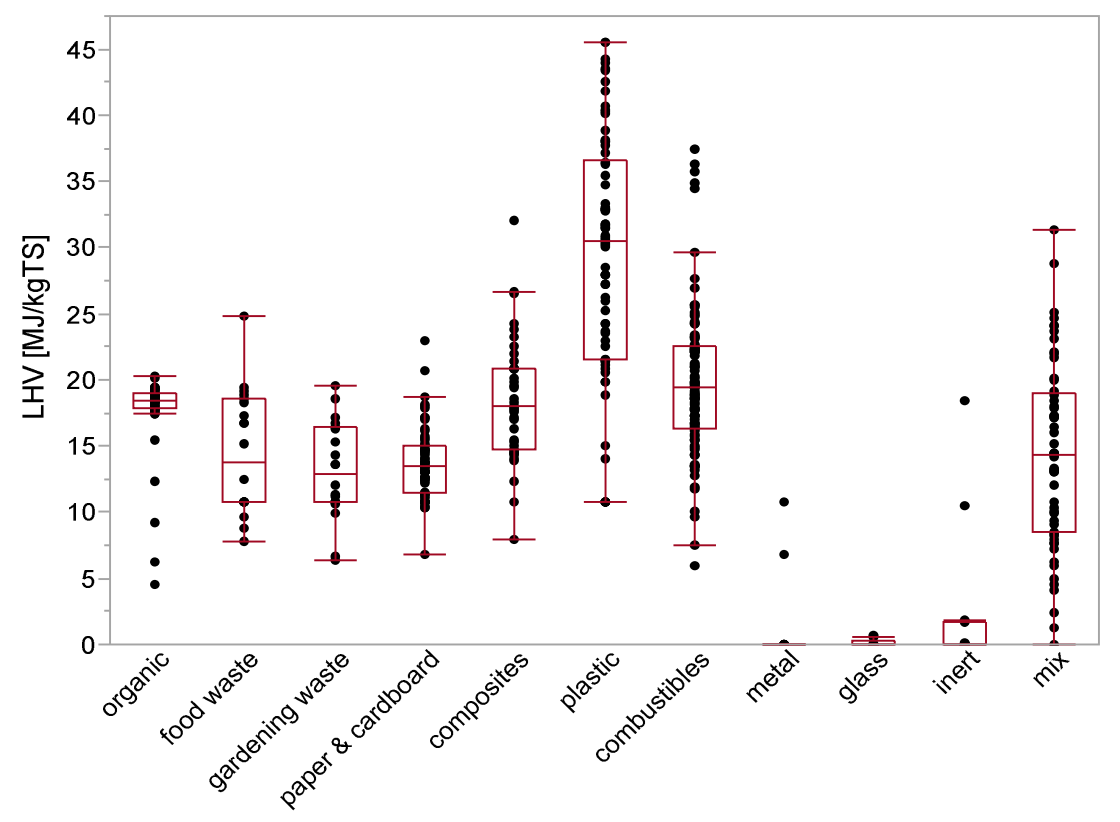

Waste Material Fractions

\section{Quantiles [MJ/kgTS]}

\begin{tabular}{|c|c|c|c|c|c|c|c|c|c|}
\hline $\begin{array}{l}\text { Waste Material } \\
\text { Fraction }\end{array}$ & n_data* & $\mathrm{n} \_<L^{* *}$ & Min & $10 \%$ & $25 \%$ & Median & $75 \%$ & $90 \%$ & Max \\
\hline organic & 50 & - & 4.6 & 15.7 & 17.9 & 18.5 & 18.9 & 19.4 & 20.3 \\
\hline food waste & 20 & - & 7.9 & 8.8 & 10.8 & 13.8 & 18.5 & 19.4 & 24.8 \\
\hline gardening waste & 20 & - & 6.4 & 7.0 & 10.8 & 12.8 & 16.5 & 18.4 & 19.5 \\
\hline paper \& cardboard & 66 & - & 6.7 & 10.8 & 11.5 & 13.4 & 15.0 & 17.3 & 23.0 \\
\hline composites & 39 & - & 7.9 & 13.9 & 14.7 & 18.0 & 20.9 & 24.2 & 32.1 \\
\hline plastic & 74 & - & 10.8 & 12.4 & 21.5 & 30.5 & 36.6 & 42.2 & 45.5 \\
\hline combustibles & 91 & - & 6.0 & 13.4 & 16.3 & 19.4 & 22.5 & 25.7 & 37.4 \\
\hline metal & 11 & - & -0.1 & -0.1 & 0.0 & 0.0 & 0.0 & 9.9 & 10.7 \\
\hline glass & 9 & - & 0.0 & 0.0 & 0.0 & 0.0 & 0.3 & 0.7 & 0.7 \\
\hline inert & 12 & - & 0.0 & 0.0 & 0.0 & 0.0 & 1.8 & 16.1 & 18.5 \\
\hline $\operatorname{mix}$ & 57 & - & 0.0 & 4.9 & 8.5 & 14.4 & 19.0 & 24.1 & 31.3 \\
\hline
\end{tabular}

$\left.{ }^{*}\right)$ number of data points

$\left.{ }^{* *}\right)$ number of values below the detection limit 
Value ranges for $\mathrm{Li}$

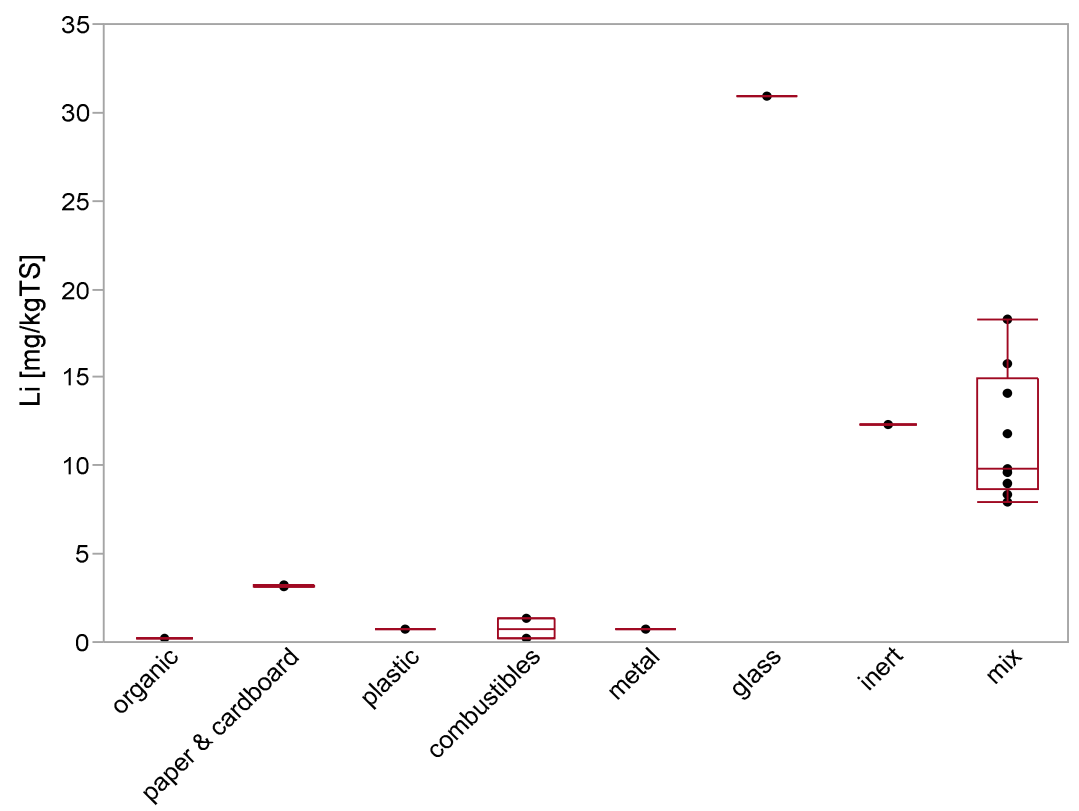

Waste Material Fractions

\section{Quantiles [mg/kgTS]}

\begin{tabular}{|c|c|c|c|c|c|c|c|c|c|}
\hline $\begin{array}{l}\text { Waste Material } \\
\text { Fraction }\end{array}$ & n_data* & $\mathrm{n}_{-}<\mathrm{DL}$ ** & Min & $10 \%$ & $25 \%$ & Median & $75 \%$ & $90 \%$ & $\operatorname{Max}$ \\
\hline organic & 1 & 1 & 0.20 & 0.20 & 0.20 & 0.20 & 0.20 & 0.20 & 0.20 \\
\hline food waste & - & - & - & - & - & - & - & - & - \\
\hline gardening waste & - & - & - & - & - & - & - & - & - \\
\hline paper \& cardboard & 2 & - & 3.14 & 3.14 & 3.14 & 3.18 & 3.22 & 3.22 & 3.22 \\
\hline composites & - & - & - & - & - & - & - & - & - \\
\hline plastic & 1 & - & 0.69 & 0.69 & 0.69 & 0.69 & 0.69 & 0.69 & 0.69 \\
\hline combustibles & 2 & 1 & 0.20 & 0.20 & 0.20 & 0.77 & 1.33 & 1.33 & 1.33 \\
\hline metal & 1 & 1 & 0.70 & 0.70 & 0.70 & 0.70 & 0.70 & 0.70 & 0.70 \\
\hline glass & 1 & - & 30.90 & 30.90 & 30.90 & 30.90 & 30.90 & 30.90 & 30.90 \\
\hline inert & 1 & - & 12.30 & 12.30 & 12.30 & 12.30 & 12.30 & 12.30 & 12.30 \\
\hline $\operatorname{mix}$ & 9 & - & 7.89 & 7.89 & 8.70 & 9.86 & 14.94 & 18.31 & 18.31 \\
\hline
\end{tabular}

*) number of data points

$\left.{ }^{\star *}\right)$ number of values below the detection limit 
Value ranges for $\mathrm{Mg}$

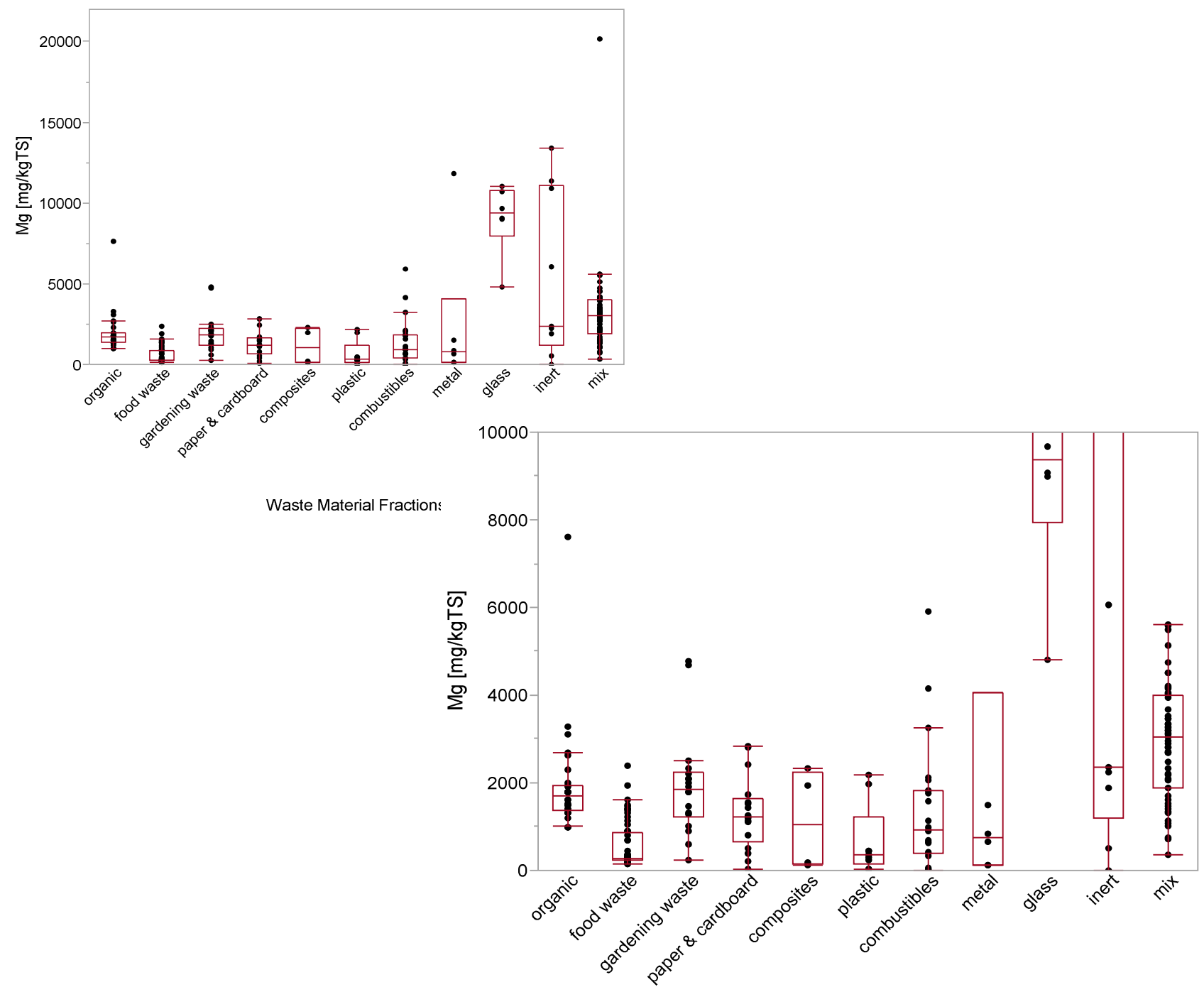

Quantiles [mg/kgTS]

Waste Material Fractions

\begin{tabular}{|c|c|c|c|c|c|c|c|c|c|}
\hline $\begin{array}{c}\text { Waste Material } \\
\text { Fraction }\end{array}$ & n_data* & $n_{-}<D L^{* *}$ & Min & $10 \%$ & $25 \%$ & Median & $75 \%$ & $90 \%$ & $\operatorname{Max}$ \\
\hline organic & 30 & - & 1000 & 1020 & 1375 & 1695 & 1949 & 3060 & 7598 \\
\hline food waste & 60 & - & 136 & 188 & 236 & 274 & 881 & 1400 & 2386 \\
\hline gardening waste & 18 & - & 239 & 564 & 1209 & 1850 & 2230 & 4708 & 4780 \\
\hline paper \& cardboard & 17 & - & 43 & 169 & 651 & 1210 & 1645 & 2817 & 2845 \\
\hline composites & 4 & - & 127 & 127 & 140 & 1060 & 2233 & 2330 & 2330 \\
\hline plastic & 9 & - & 19 & 19 & 142 & 344 & 1213 & 2170 & 2170 \\
\hline combustibles & 23 & - & 13 & 21 & 375 & 917 & 1820 & 3792 & 5920 \\
\hline metal & 6 & - & 105 & 105 & 119 & 756 & 4060 & 11800 & 11800 \\
\hline glass & 6 & - & 4800 & 4800 & 7949 & 9370 & 10780 & 11020 & 11020 \\
\hline inert & 9 & - & 0 & 0 & 1200 & 2350 & 11125 & 13400 & 13400 \\
\hline $\operatorname{mix}$ & 55 & - & 345 & 1117 & 1874 & 3039 & 4000 & 4903 & 20160 \\
\hline
\end{tabular}

*) number of data points

${ }^{* *}$ ) number of values below the detection limit 
Value ranges for $\mathrm{Mn}$

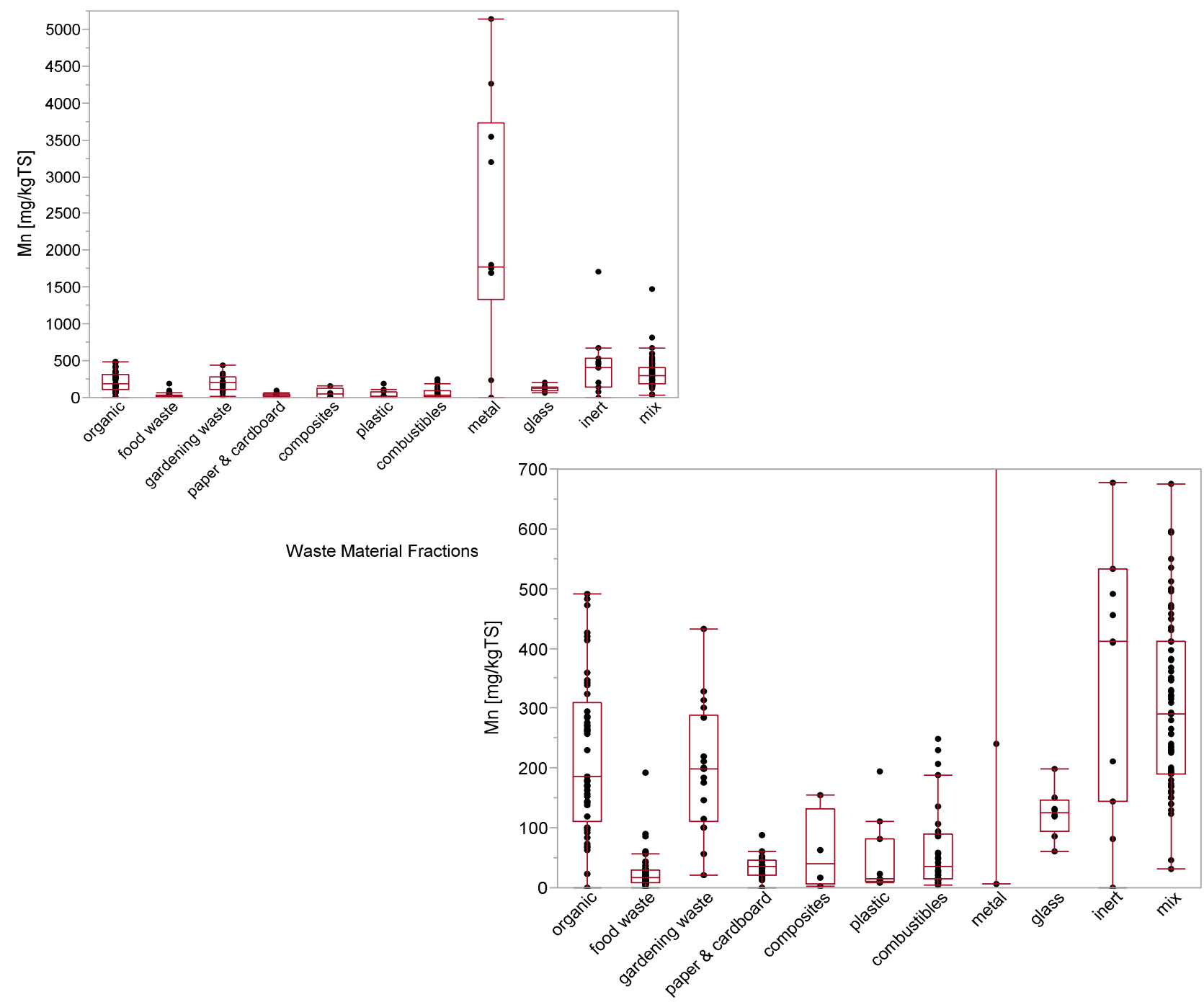

Quantiles [mg/kgTS]

Waste Material Fractions

\begin{tabular}{|c|c|c|c|c|c|c|c|c|c|}
\hline $\begin{array}{c}\text { Waste Material } \\
\text { Fraction }\end{array}$ & n_data* & $\mathrm{n}_{-}<\mathrm{DL}^{* *}$ & Min & $10 \%$ & $25 \%$ & Median & $75 \%$ & $90 \%$ & $\operatorname{Max}$ \\
\hline organic & 45 & - & 0.0 & 67.8 & 110.7 & 185.5 & 308.6 & 422.2 & 490.6 \\
\hline food waste & 58 & - & 0.0 & 5.9 & 9.2 & 16.5 & 28.4 & 56.0 & 193.0 \\
\hline gardening waste & 18 & - & 21.6 & 52.6 & 111.3 & 198.6 & 287.9 & 338.9 & 433.0 \\
\hline paper \& cardboard & 22 & - & 0.0 & 13.2 & 20.3 & 34.7 & 45.3 & 58.3 & 88.2 \\
\hline composites & 4 & - & 2.2 & 2.2 & 5.7 & 39.5 & 132.0 & 155.0 & 155.0 \\
\hline plastic & 11 & - & 7.7 & 7.7 & 10.0 & 14.0 & 82.0 & 178.2 & 195.0 \\
\hline combustibles & 31 & - & 4.8 & 8.1 & 15.0 & 36.0 & 89.0 & 202.6 & 248.0 \\
\hline metal & 10 & - & 6.3 & 29.7 & 1327.5 & 1775.0 & 3722.5 & 5053.0 & 5140.0 \\
\hline glass & 8 & - & 61.0 & 61.0 & 93.8 & 125.5 & 145.3 & 199.0 & 199.0 \\
\hline inert & 11 & - & 0.0 & 16.4 & 145.0 & 412.0 & 532.0 & 1503.4 & 1710.0 \\
\hline $\operatorname{mix}$ & 68 & - & 30.9 & 149.0 & 190.2 & 290.2 & 412.0 & 536.7 & 1476.0 \\
\hline
\end{tabular}

*) number of data points

${ }^{* *}$ ) number of values below the detection limit 
Value ranges for Mo

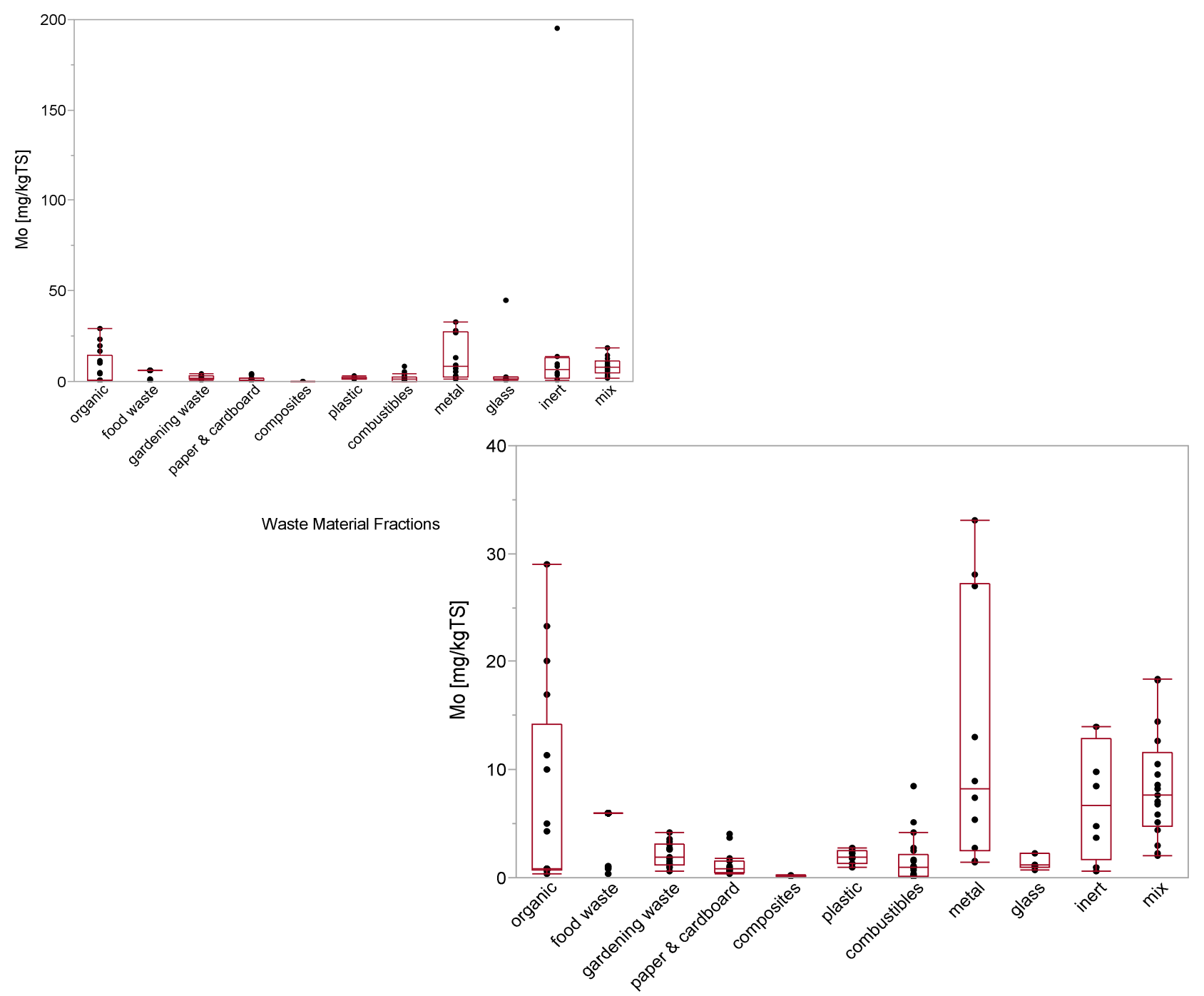

Quantiles [mg/kgTS]

Waste Material Fractions

\begin{tabular}{|c|c|c|c|c|c|c|c|c|c|}
\hline $\begin{array}{c}\text { Waste Material } \\
\text { Fraction }\end{array}$ & n_data* & $n_{-}<D^{* *}$ & Min & $10 \%$ & $25 \%$ & Median & $75 \%$ & $90 \%$ & $\operatorname{Max}$ \\
\hline organic & 17 & - & 0.34 & 0.60 & 0.75 & 0.81 & 14.15 & 24.44 & 29.00 \\
\hline food waste & 44 & 41 & 0.30 & 3.55 & 6.00 & 6.00 & 6.00 & 6.00 & 6.00 \\
\hline gardening waste & 15 & 4 & 0.65 & 0.86 & 1.20 & 1.89 & 3.06 & 3.82 & 4.17 \\
\hline paper \& cardboard & 15 & 1 & 0.32 & 0.40 & 0.50 & 0.79 & 1.50 & 3.86 & 4.10 \\
\hline composites & 2 & - & 0.11 & 0.11 & 0.11 & 0.15 & 0.19 & 0.19 & 0.19 \\
\hline plastic & 7 & - & 0.92 & 0.92 & 1.30 & 1.95 & 2.50 & 2.80 & 2.80 \\
\hline combustibles & 21 & 5 & 0.12 & 0.13 & 0.17 & 1.00 & 2.10 & 4.92 & 8.50 \\
\hline metal & 10 & 2 & 1.40 & 1.42 & 2.50 & 8.20 & 27.25 & 32.59 & 33.10 \\
\hline glass & 7 & 1 & 0.75 & 0.75 & 1.00 & 1.20 & 2.30 & 45.00 & 45.00 \\
\hline inert & 8 & 1 & 0.54 & 0.54 & 1.68 & 6.67 & 12.95 & 195.00 & 195.00 \\
\hline $\operatorname{mix}$ & 17 & - & 2.00 & 2.18 & 4.75 & 7.70 & 11.61 & 18.33 & 18.42 \\
\hline
\end{tabular}

*) number of data points

${ }^{* *}$ ) number of values below the detection limit 


\section{Value ranges for $\mathrm{N}$}

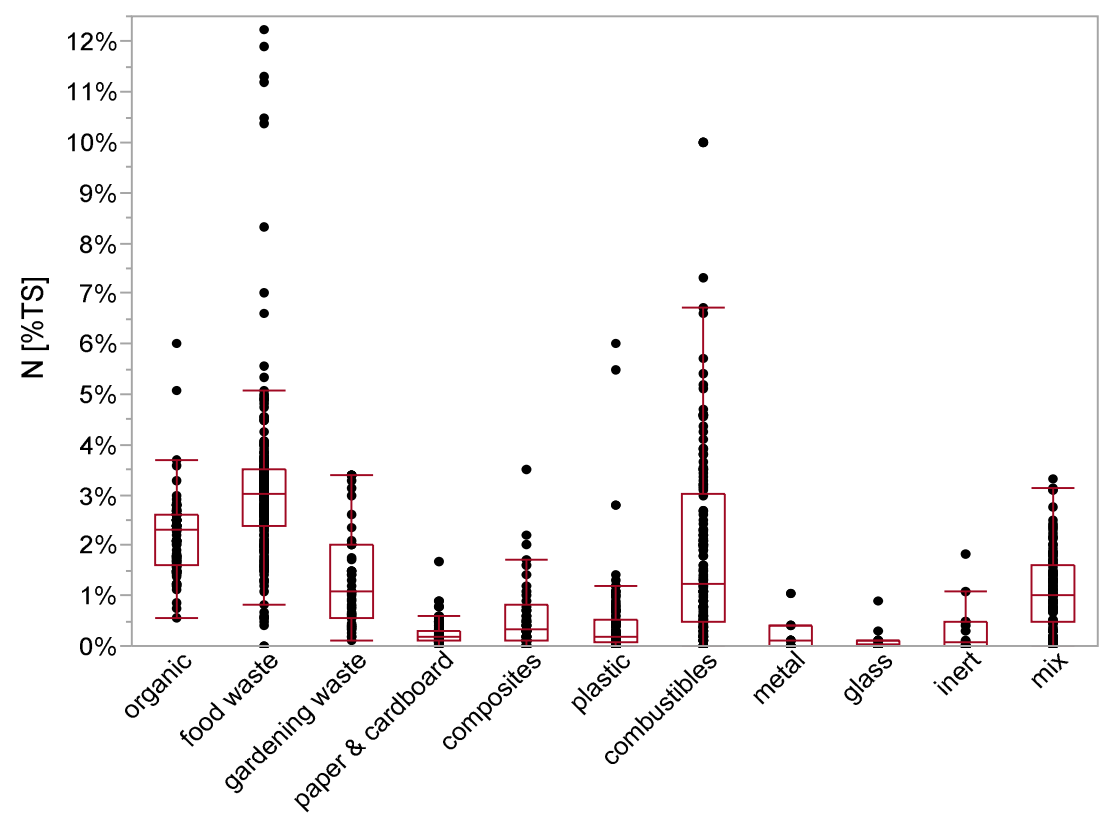

Waste Material Fractions

\section{Quantiles [\%TS]}

\section{Waste Material}

\begin{tabular}{lrrrrrrrrr}
\multicolumn{1}{c}{ Fraction } & $\mathbf{n}$ data*$^{*}$ & $\mathbf{n}<\mathbf{D L}^{* *}$ & Min & $\mathbf{1 0 \%}$ & $\mathbf{2 5 \%}$ & Median & $\mathbf{7 5 \%}$ & $\mathbf{9 0 \%}$ & $\mathbf{M a x}$ \\
\hline organic & 104 & - & $0.56 \%$ & $1.40 \%$ & $1.61 \%$ & $2.30 \%$ & $2.60 \%$ & $2.80 \%$ & $6.00 \%$ \\
food waste & 212 & - & $0.00 \%$ & $1.59 \%$ & $2.39 \%$ & $3.01 \%$ & $3.50 \%$ & $4.55 \%$ & $12.23 \%$ \\
gardening waste & 49 & - & $0.10 \%$ & $0.33 \%$ & $0.57 \%$ & $1.09 \%$ & $2.00 \%$ & $3.40 \%$ & $3.40 \%$ \\
paper \& cardboard & 114 & 1 & $0.00 \%$ & $0.09 \%$ & $0.10 \%$ & $0.20 \%$ & $0.30 \%$ & $0.49 \%$ & $1.69 \%$ \\
composites & 42 & - & $0.00 \%$ & $0.00 \%$ & $0.12 \%$ & $0.35 \%$ & $0.83 \%$ & $1.67 \%$ & $3.50 \%$ \\
plastic & 116 & 1 & $0.00 \%$ & $0.00 \%$ & $0.06 \%$ & $0.20 \%$ & $0.53 \%$ & $1.03 \%$ & $6.00 \%$ \\
combustibles & 146 & - & $0.00 \%$ & $0.18 \%$ & $0.47 \%$ & $1.22 \%$ & $3.03 \%$ & $4.60 \%$ & $10.00 \%$ \\
metal & 13 & 3 & $0.00 \%$ & $0.00 \%$ & $0.00 \%$ & $0.10 \%$ & $0.40 \%$ & $1.05 \%$ & $1.05 \%$ \\
glass & 13 & 3 & $0.00 \%$ & $0.00 \%$ & $0.00 \%$ & $0.04 \%$ & $0.10 \%$ & $0.65 \%$ & $0.88 \%$ \\
inert & 14 & - & $0.00 \%$ & $0.00 \%$ & $0.00 \%$ & $0.08 \%$ & $0.50 \%$ & $1.46 \%$ & $1.81 \%$ \\
mix & 117 & - & $0.00 \%$ & $0.12 \%$ & $0.48 \%$ & $1.05 \%$ & $1.67 \%$ & $2.33 \%$ & $13.16 \%$ \\
\hline Total & 940 & 8 & & & & & & &
\end{tabular}

*) number of data points

${ }^{* *}$ ) number of values below the detection limit 


\section{Value ranges for $\mathrm{Na}$}

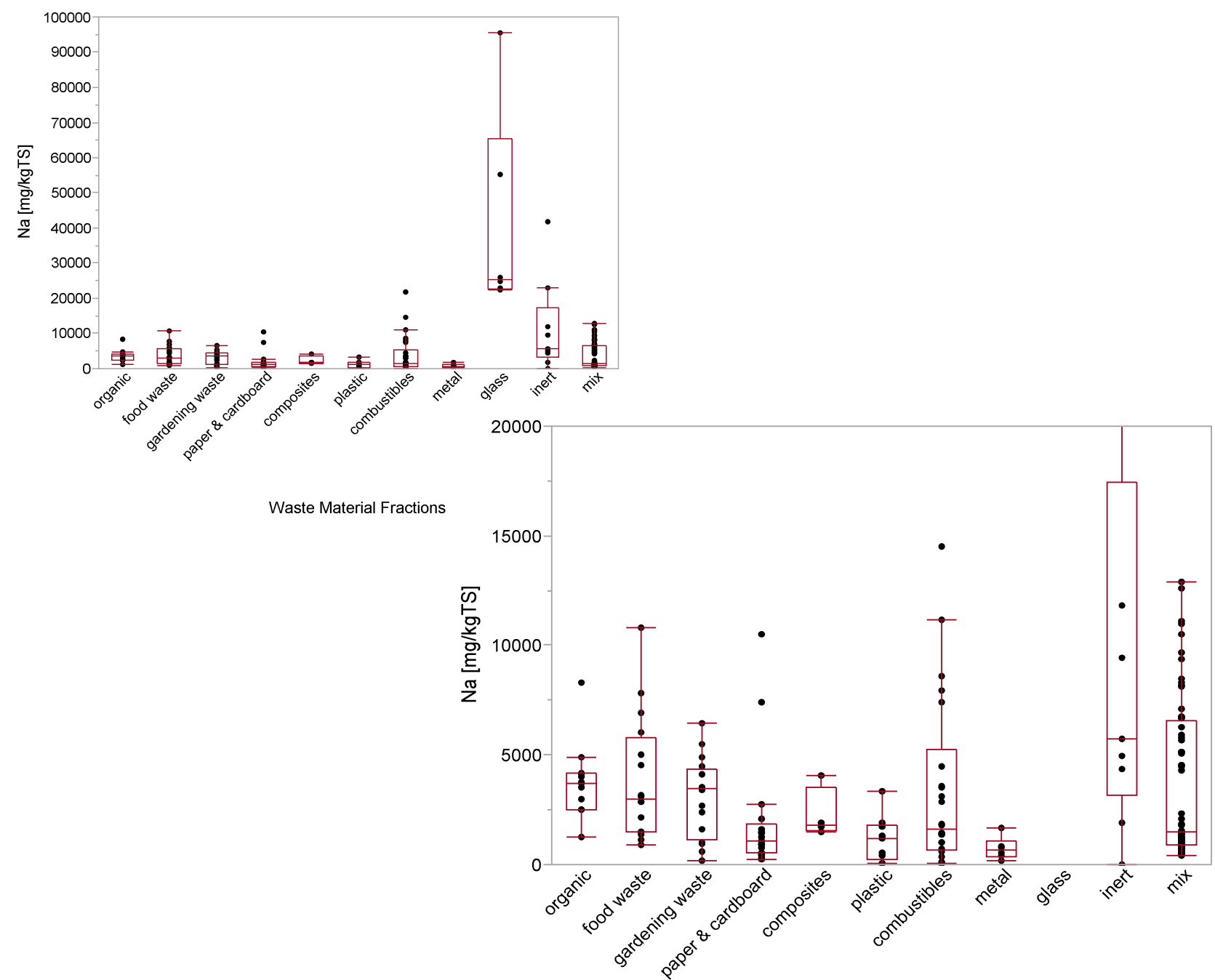

Waste Material Fractions

\section{Quantiles [mg/kgTS]}

\section{Waste Material}

\begin{tabular}{lrrrrrrrrr}
\multicolumn{1}{c}{ Fraction } & $\mathbf{n}_{\mathbf{d}} \mathbf{d a t a}^{*}$ & $\mathbf{n} \_\mathbf{D L}^{* *}$ & \multicolumn{1}{c}{ Min } & $\mathbf{1 0 \%}$ & $\mathbf{2 5 \%}$ & Median & $\mathbf{7 5 \%}$ & $\mathbf{9 0 \%}$ & Max \\
\hline organic & 13 & - & 1250 & 1750 & 2500 & 3720 & 4150 & 6940 & 8300 \\
food waste & 16 & - & 877 & 1058 & 1483 & 2980 & 5767 & 8729 & 10800 \\
gardening waste & 16 & - & 168 & 470 & 1150 & 3441 & 4375 & 5782 & 6423 \\
paper \& cardboard & 17 & - & 246 & 272 & 511 & 1090 & 1835 & 8020 & 10500 \\
composites & 4 & - & 1500 & 1500 & 1560 & 1820 & 3520 & 4060 & 4060 \\
plastic & 9 & - & 36 & 36 & 250 & 1170 & 1810 & 3340 & 3340 \\
combustibles & 26 & - & 39 & 52 & 671 & 1630 & 5225 & 12162 & 21900 \\
metal & 6 & - & 165 & 165 & 334 & 648 & 1054 & 1670 & 1670 \\
glass & 6 & - & 22400 & 22400 & 22820 & 25500 & 65343 & 95500 & 95500 \\
inert & 9 & - & 0 & 0 & 3135 & 5760 & 17411 & 41700 & 41700 \\
mix & 64 & - & 437 & 605 & 890 & 1502 & 6580 & 9534 & 12876 \\
\hline Total & 186 & 0 & & & & & & &
\end{tabular}

*) number of data points

${ }^{* *}$ ) number of values below the detection limit 


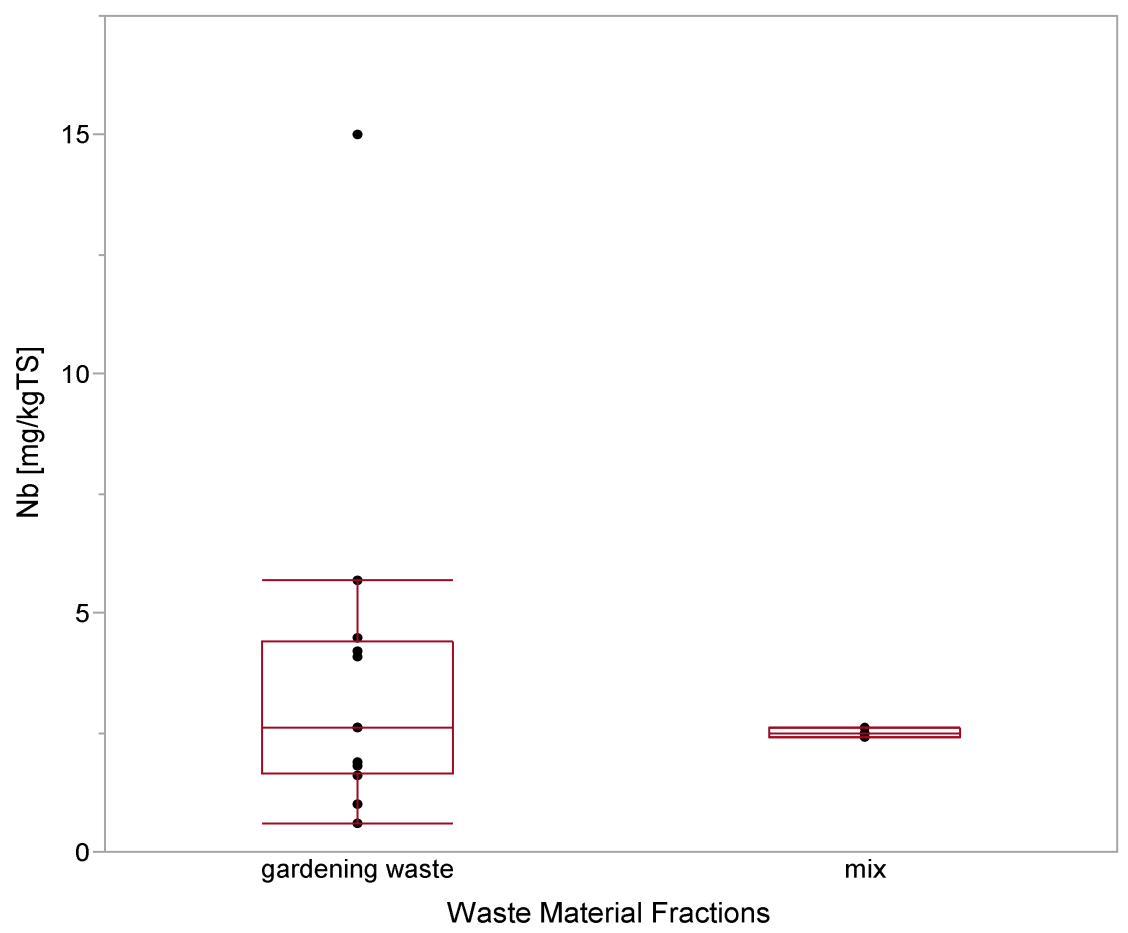

\section{Quantiles [mg/kgTS]}

\section{Waste Material}

Fraction

n_data* n_<DL** $^{*}$

Min

$10 \%$

$25 \%$

Median

$75 \%$

$90 \%$

$\operatorname{Max}$

organic

food waste

gardening waste

12

$11 \quad 0.600$

0.720

1.650

2.600

4.425

12.210

15.000

paper \& cardboaro

composites

plastic

combustibles

metal

glass

inert

mix

2.400

2.400

2.400

2.500

2.600

2.600

2.600

*) number of data points

${ }^{* *}$ ) number of values below the detection limit 


\section{Value ranges for $\mathrm{Ni}$}

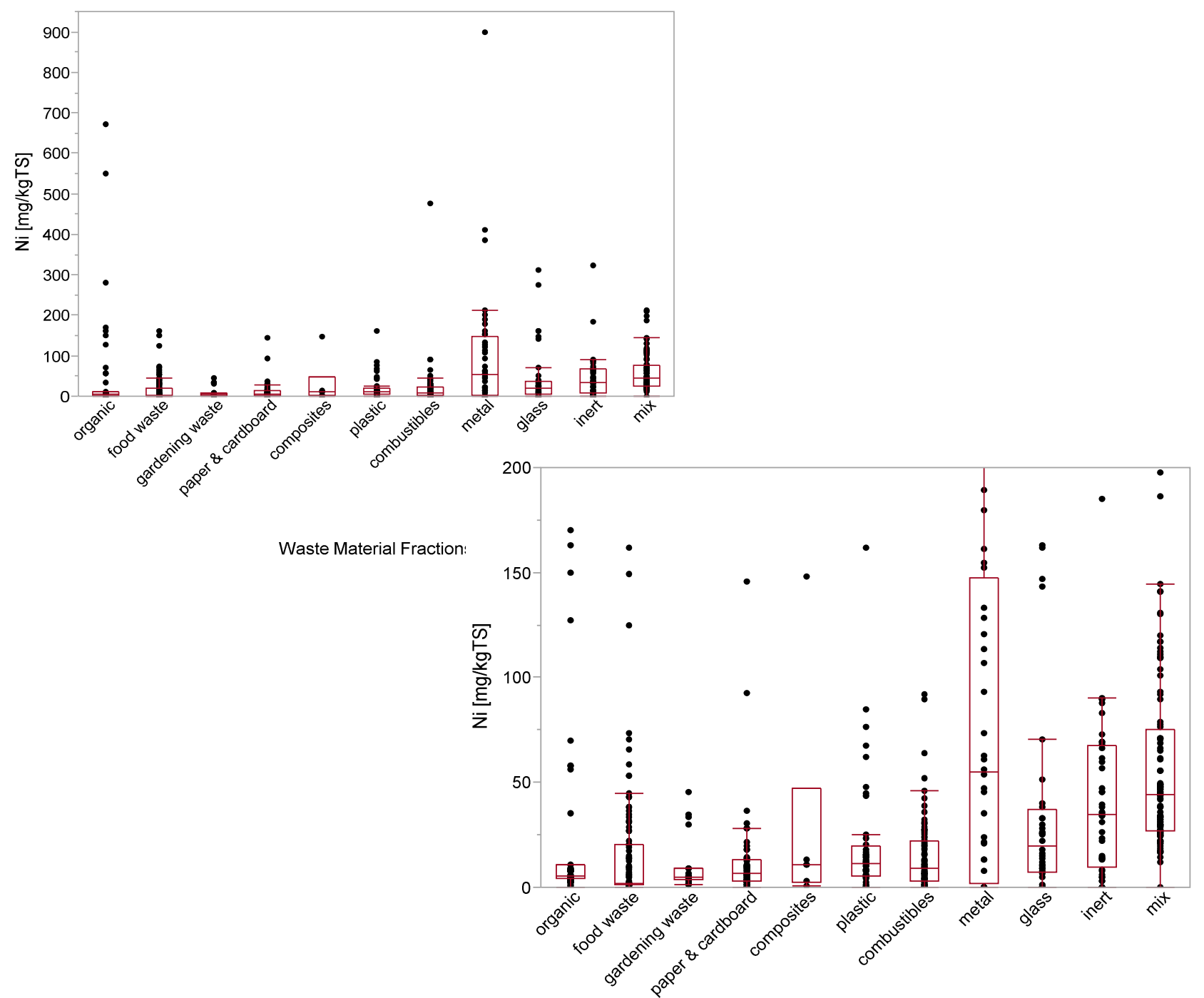

\section{Quantiles [mg/kgTS]}

Waste Material Fractions

\begin{tabular}{|c|c|c|c|c|c|c|c|c|c|}
\hline $\begin{array}{c}\text { Waste Material } \\
\text { Fraction }\end{array}$ & n_data* & $\mathrm{n}_{-}<\mathrm{DL} * *$ & Min & $10 \%$ & $25 \%$ & Median & $75 \%$ & $90 \%$ & $\operatorname{Max}$ \\
\hline organic & 51 & - & 0.0 & 2.3 & 3.9 & 5.6 & 10.5 & 160.4 & 673.0 \\
\hline food waste & 99 & 24 & 0.0 & 1.0 & 1.0 & 2.0 & 20.4 & 44.9 & 162.0 \\
\hline gardening waste & 20 & - & 1.0 & 1.6 & 3.5 & 4.8 & 9.0 & 34.6 & 45.6 \\
\hline paper \& cardboard & 57 & 2 & 0.0 & 0.9 & 3.2 & 6.5 & 13.3 & 28.0 & 145.6 \\
\hline composites & 6 & - & 0.5 & 0.5 & 2.2 & 10.8 & 47.1 & 148.3 & 148.3 \\
\hline plastic & 44 & - & 0.0 & 0.2 & 5.4 & 11.6 & 19.6 & 64.9 & 161.8 \\
\hline combustibles & 97 & - & 0.0 & 0.0 & 3.2 & 8.8 & 22.0 & 33.2 & 476.0 \\
\hline metal & 40 & - & 0.0 & 0.0 & 2.0 & 55.0 & 147.3 & 211.4 & 900.0 \\
\hline glass & 40 & - & 0.0 & 0.0 & 6.9 & 19.9 & 37.1 & 160.5 & 313.0 \\
\hline inert & 44 & - & 0.0 & 1.6 & 9.3 & 34.7 & 67.7 & 89.3 & 322.0 \\
\hline $\operatorname{mix}$ & 104 & - & 0.0 & 20.5 & 26.8 & 44.2 & 75.2 & 118.5 & 211.3 \\
\hline
\end{tabular}

*) number of data points

${ }^{* *}$ ) number of values below the detection limit 


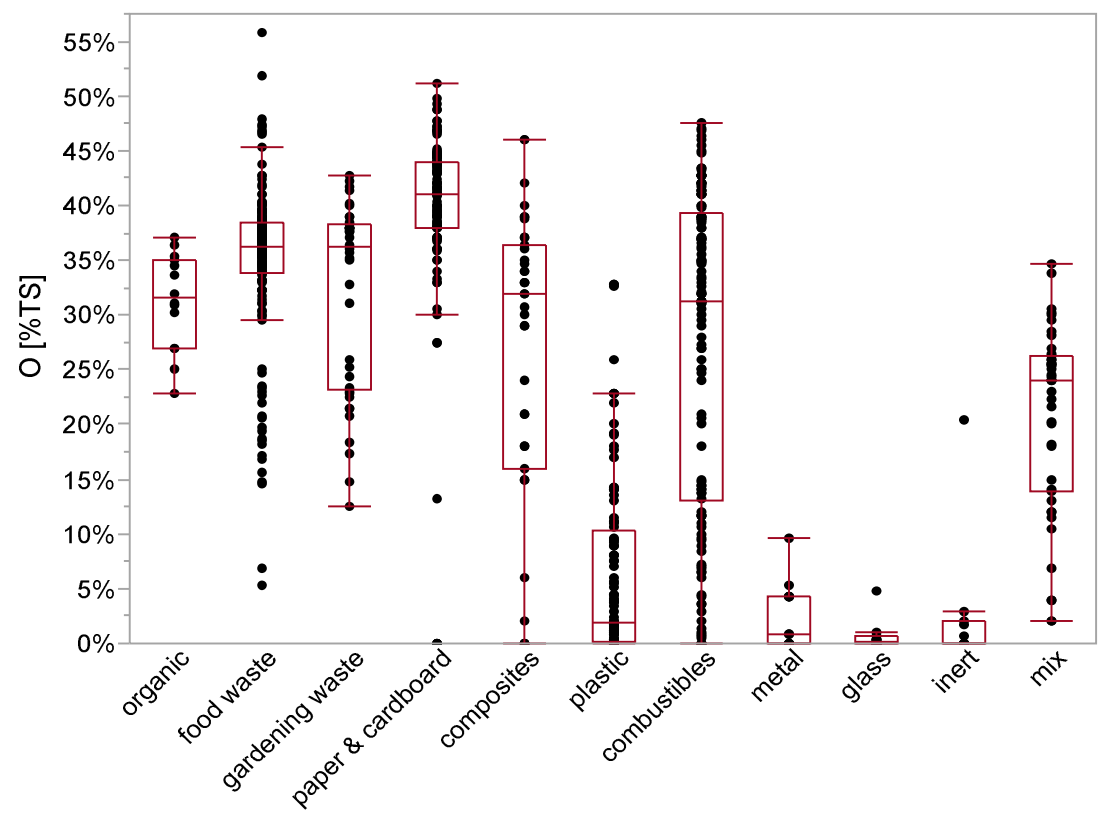

Waste Material Fractions

\section{Quantiles [\%TS]}

\begin{tabular}{|c|c|c|c|c|c|c|c|c|c|}
\hline $\begin{array}{l}\text { Waste Material } \\
\text { Fraction }\end{array}$ & n_data* & $\mathrm{n} \_$<DL** & Min & $10 \%$ & $25 \%$ & Median & $75 \%$ & $90 \%$ & Max \\
\hline organic & 14 & - & $22.9 \%$ & $24.0 \%$ & $26.9 \%$ & $31.5 \%$ & $35.1 \%$ & $36.7 \%$ & $37.0 \%$ \\
\hline food waste & 173 & - & $5.3 \%$ & $23.1 \%$ & $33.8 \%$ & $36.2 \%$ & $38.5 \%$ & $40.7 \%$ & $55.8 \%$ \\
\hline gardening waste & 40 & - & $12.6 \%$ & $18.6 \%$ & $23.1 \%$ & $36.2 \%$ & $38.2 \%$ & $41.2 \%$ & $42.7 \%$ \\
\hline paper \& cardboard & 112 & - & $0.0 \%$ & $32.9 \%$ & $38.0 \%$ & $41.1 \%$ & $44.0 \%$ & $46.8 \%$ & $51.2 \%$ \\
\hline composites & 39 & - & $0.0 \%$ & $0.0 \%$ & $16.0 \%$ & $32.0 \%$ & $36.4 \%$ & $40.0 \%$ & $46.0 \%$ \\
\hline plastic & 112 & - & $0.0 \%$ & $0.0 \%$ & $0.2 \%$ & $1.9 \%$ & $10.3 \%$ & $19.1 \%$ & $32.8 \%$ \\
\hline combustibles & 130 & - & $0.0 \%$ & $3.7 \%$ & $13.0 \%$ & $31.3 \%$ & $39.2 \%$ & $42.7 \%$ & $47.6 \%$ \\
\hline metal & 13 & - & $0.0 \%$ & $0.0 \%$ & $0.0 \%$ & $0.8 \%$ & $4.3 \%$ & $7.9 \%$ & $9.6 \%$ \\
\hline glass & 12 & - & $0.0 \%$ & $0.0 \%$ & $0.0 \%$ & $0.2 \%$ & $0.6 \%$ & $3.7 \%$ & $4.8 \%$ \\
\hline inert & 11 & - & $0.0 \%$ & $0.0 \%$ & $0.0 \%$ & $0.0 \%$ & $2.0 \%$ & $17.0 \%$ & $20.5 \%$ \\
\hline $\operatorname{mix}$ & 43 & - & $2.0 \%$ & $5.1 \%$ & $13.8 \%$ & $24.0 \%$ & $26.3 \%$ & $30.2 \%$ & $34.6 \%$ \\
\hline
\end{tabular}

*) number of data points

${ }^{* *}$ ) number of values below the detection limit 


\section{Value ranges for $P$}

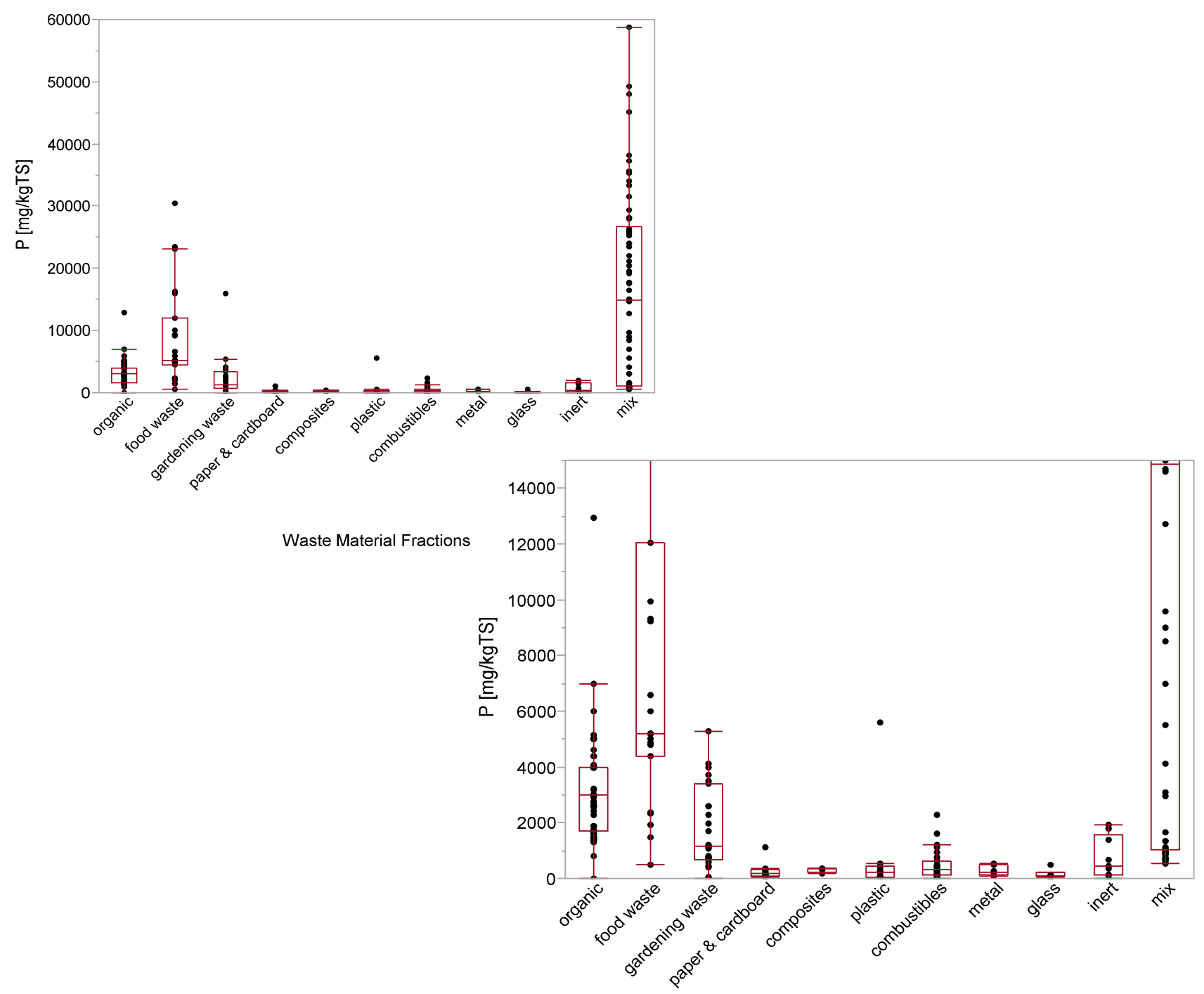

Quantiles [mg/kgTS]

Waste Material Fractions

\begin{tabular}{|c|c|c|c|c|c|c|c|c|c|}
\hline $\begin{array}{l}\text { Waste Material } \\
\text { Fraction }\end{array}$ & n_data* & $n_{-}<D L^{* *}$ & Min & $10 \%$ & $25 \%$ & Median & $75 \%$ & $90 \%$ & $\operatorname{Max}$ \\
\hline organic & 85 & - & 5 & 1438 & 1700 & 3000 & 4000 & 5000 & 12950 \\
\hline food waste & 23 & - & 489 & 1659 & 4400 & 5200 & 12045 & 23386 & 30455 \\
\hline gardening waste & 27 & - & 21 & 28 & 666 & 1184 & 3400 & 4340 & 15900 \\
\hline paper \& cardboard & 18 & - & 38 & 43 & 109 & 164 & 291 & 422 & 1100 \\
\hline composites & 4 & - & 189 & 189 & 224 & 340 & 373 & 380 & 380 \\
\hline plastic & 10 & - & 15 & 16 & 63 & 244 & 445 & 5104 & 5610 \\
\hline combustibles & 27 & - & 13 & 30 & 148 & 300 & 608 & 1294 & 2300 \\
\hline metal & 6 & - & 110 & 110 & 139 & 232 & 498 & 551 & 551 \\
\hline glass & 6 & 1 & 64 & 64 & 70 & 98 & 212 & 480 & 480 \\
\hline inert & 9 & - & 0 & 0 & 141 & 439 & 1585 & 1920 & 1920 \\
\hline $\operatorname{mix}$ & 62 & - & 550 & 736 & 1051 & 14850 & 26725 & 36750 & 58800 \\
\hline
\end{tabular}

*) number of data points

${ }^{* *}$ ) number of values below the detection limit 


\section{Value ranges for $\mathrm{Pb}$}

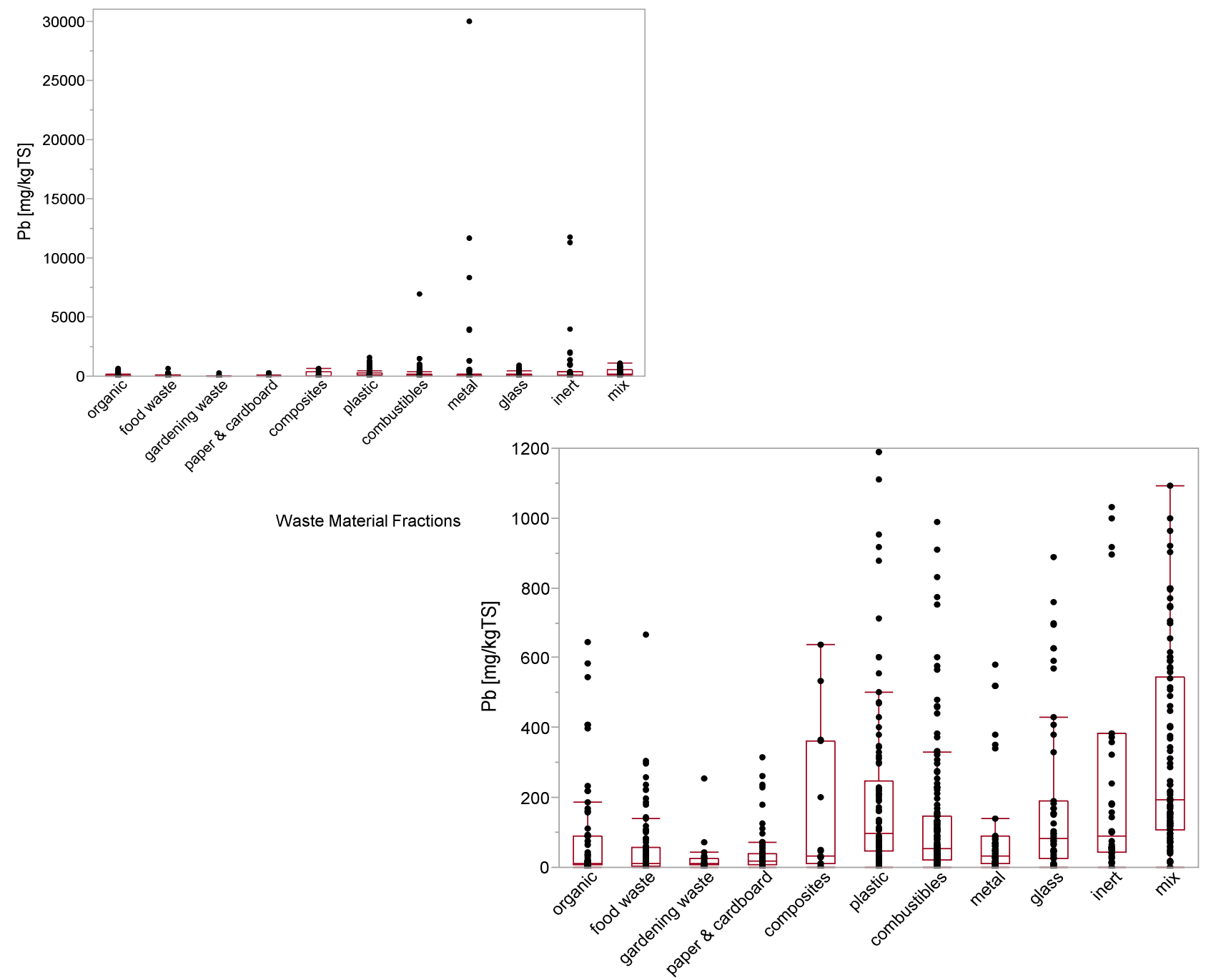

\section{Quantiles [mg/kgTS]}

Waste Material Fractions

\begin{tabular}{|c|c|c|c|c|c|c|c|c|c|}
\hline $\begin{array}{c}\text { Waste Material } \\
\text { Fraction }\end{array}$ & n_data* & $\mathrm{n}_{-}<\mathrm{DL} * *$ & Min & $10 \%$ & $25 \%$ & Median & $75 \%$ & $90 \%$ & $\operatorname{Max}$ \\
\hline organic & 68 & - & 0.0 & 3.4 & 6.7 & 10.7 & 89.1 & 250.3 & 643.2 \\
\hline food waste & 105 & 40 & 0.0 & 2.0 & 2.0 & 11.0 & 56.9 & 157.6 & 666.9 \\
\hline gardening waste & 25 & - & 0.0 & 2.0 & 6.7 & 9.6 & 23.7 & 54.8 & 255.3 \\
\hline paper \& cardboard & 88 & 2 & 0.0 & 2.7 & 7.6 & 17.4 & 39.8 & 74.4 & 316.0 \\
\hline composites & 15 & - & 0.7 & 1.0 & 9.0 & 34.0 & 363.3 & 575.2 & 638.0 \\
\hline plastic & 102 & - & 0.8 & 21.9 & 46.6 & 98.2 & 247.0 & 602.0 & 1595.0 \\
\hline combustibles & 155 & 3 & 0.0 & 9.1 & 23.0 & 53.8 & 147.0 & 405.2 & 6900.0 \\
\hline metal & 67 & 1 & 0.0 & 0.0 & 9.0 & 33.0 & 90.0 & 1283.2 & 30010.0 \\
\hline glass & 51 & - & 0.0 & 0.0 & 24.6 & 81.5 & 189.1 & 628.0 & 889.0 \\
\hline inert & 50 & - & 0.0 & 13.1 & 41.3 & 88.4 & 382.3 & 1910.5 & 11740.0 \\
\hline $\operatorname{mix}$ & 102 & 3 & 0.0 & 47.4 & 107.1 & 191.9 & 544.6 & 764.0 & 1092.1 \\
\hline
\end{tabular}

*) number of data points

$\left.{ }^{* *}\right)$ number of values below the detection limit 
Value ranges for $S$

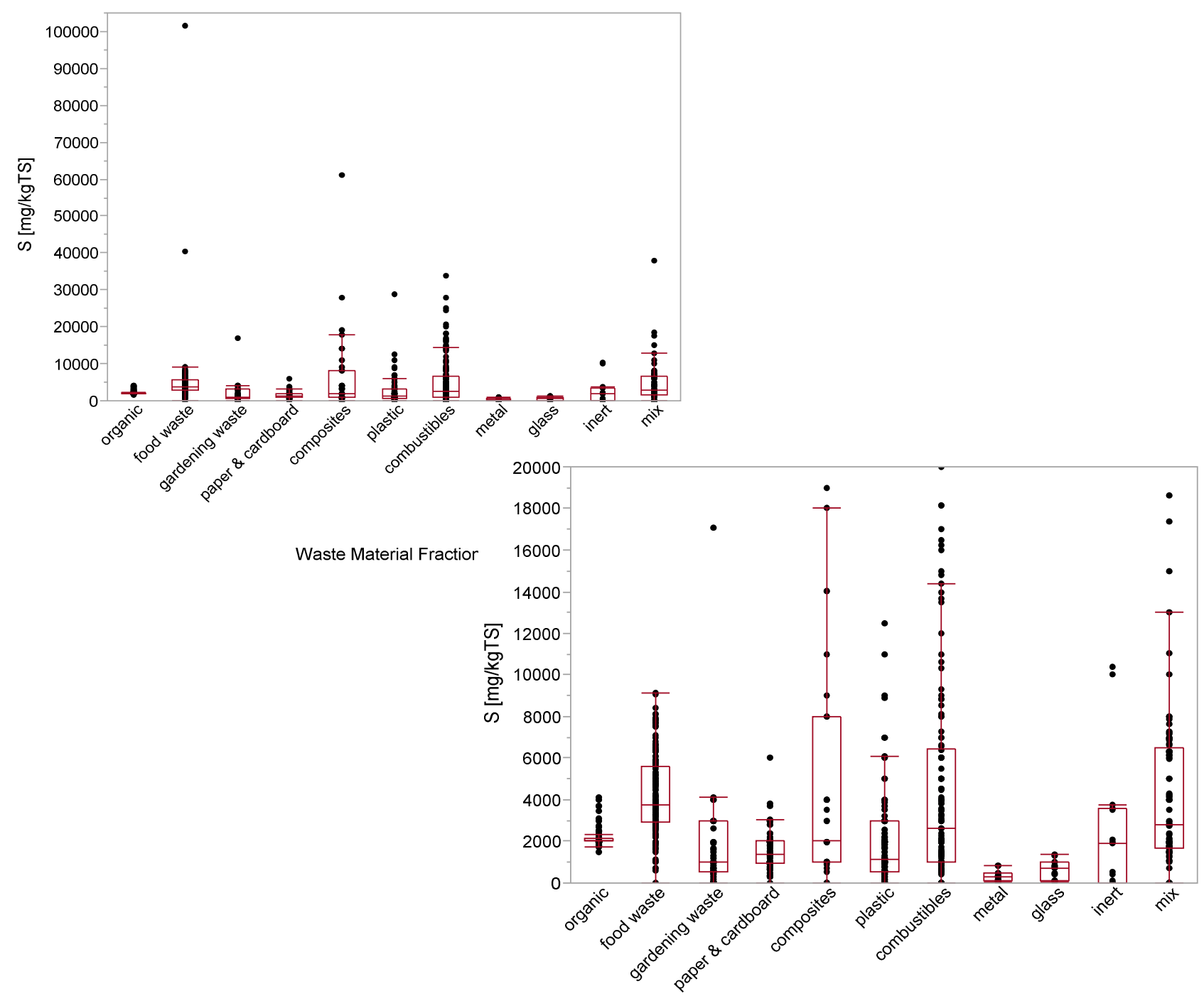

Quantiles [mg/kgTS]

Waste Material Fractions

\begin{tabular}{|c|c|c|c|c|c|c|c|c|c|}
\hline $\begin{array}{c}\text { Waste Material } \\
\text { Fraction }\end{array}$ & n_data* & $\mathrm{n}_{-}<\mathrm{DL} \mathrm{L}^{* *}$ & Min & $10 \%$ & $25 \%$ & Median & $75 \%$ & $90 \%$ & $\operatorname{Max}$ \\
\hline organic & 67 & - & 1500 & 1888 & 2000 & 2000 & 2170 & 3020 & 4100 \\
\hline food waste & 175 & - & 0 & 1960 & 2900 & 3780 & 5600 & 7510 & 101700 \\
\hline gardening waste & 39 & - & 0 & 51 & 557 & 1000 & 3000 & 4000 & 17065 \\
\hline paper \& cardboard & 81 & - & 0 & 526 & 944 & 1400 & 2000 & 3000 & 6000 \\
\hline composites & 37 & - & 0 & 0 & 1000 & 2000 & 8000 & 18200 & 61000 \\
\hline plastic & 101 & 2 & 0 & 0 & 520 & 1125 & 3000 & 6000 & 28740 \\
\hline combustibles & 142 & 3 & 0 & 587 & 1000 & 2600 & 6428 & 14654 & 34000 \\
\hline metal & 13 & 2 & 30 & 30 & 95 & 297 & 500 & 808 & 808 \\
\hline glass & 11 & - & 50 & 58 & 111 & 687 & 1000 & 1383 & 1400 \\
\hline inert & 15 & - & 0 & 0 & 0 & 1920 & 3590 & 10164 & 10410 \\
\hline $\operatorname{mix}$ & 85 & - & 0 & 419 & 1694 & 2800 & 6490 & 8006 & 38000 \\
\hline
\end{tabular}

*) number of data points

${ }^{* *}$ ) number of values below the detection limit 


\section{Value ranges for $\mathrm{Sb}$}

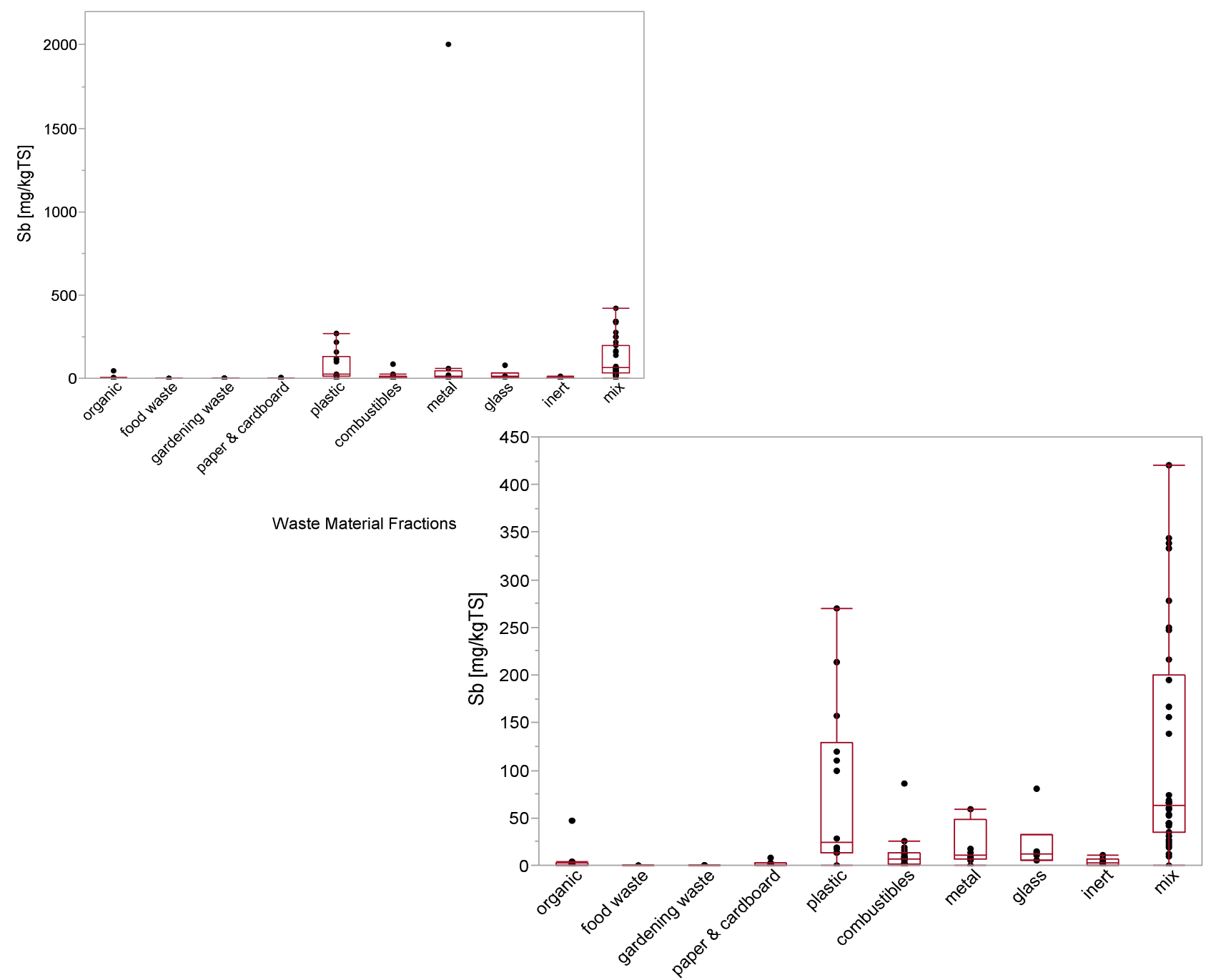

\section{Quantiles [mg/kgTS]}

Waste Material Fractions

\begin{tabular}{|c|c|c|c|c|c|c|c|c|c|}
\hline $\begin{array}{c}\text { Waste Material } \\
\text { Fraction }\end{array}$ & n_data* & $\mathrm{n}_{-}<\mathrm{DL}$ ** & Min & $10 \%$ & $25 \%$ & Median & $75 \%$ & $90 \%$ & Max \\
\hline organic & 12 & 5 & 0.02 & 0.16 & 0.50 & 0.60 & 2.60 & 34.04 & 47.00 \\
\hline food waste & 2 & 1 & 0.00 & 0.00 & 0.00 & 0.25 & 0.50 & 0.50 & 0.50 \\
\hline gardening waste & 13 & 4 & 0.00 & 0.00 & 0.00 & 0.04 & 0.11 & 0.18 & 0.20 \\
\hline paper \& cardboard & 8 & 2 & 0.00 & 0.00 & 0.20 & 0.56 & 2.45 & 7.90 & 7.90 \\
\hline composites & - & - & - & - & - & - & - & - & - \\
\hline plastic & 14 & - & 0.00 & 0.00 & 12.88 & 24.00 & 129.23 & 242.18 & 270.60 \\
\hline combustibles & 23 & - & 0.00 & 0.00 & 0.90 & 6.20 & 13.00 & 22.68 & 86.30 \\
\hline metal & 8 & 1 & 0.50 & 0.50 & 6.45 & 11.40 & 48.73 & 2000.00 & 2000.00 \\
\hline glass & 6 & - & 5.90 & 5.90 & 5.98 & 12.28 & 31.70 & 81.20 & 81.20 \\
\hline inert & 7 & 1 & 0.00 & 0.00 & 0.50 & 2.70 & 6.07 & 11.10 & 11.10 \\
\hline $\operatorname{mix}$ & 34 & - & 0.00 & 15.16 & 34.28 & 62.90 & 200.10 & 336.00 & 420.00 \\
\hline
\end{tabular}

*) number of data points

${ }^{* *}$ ) number of values below the detection limit 
Value ranges for Sc

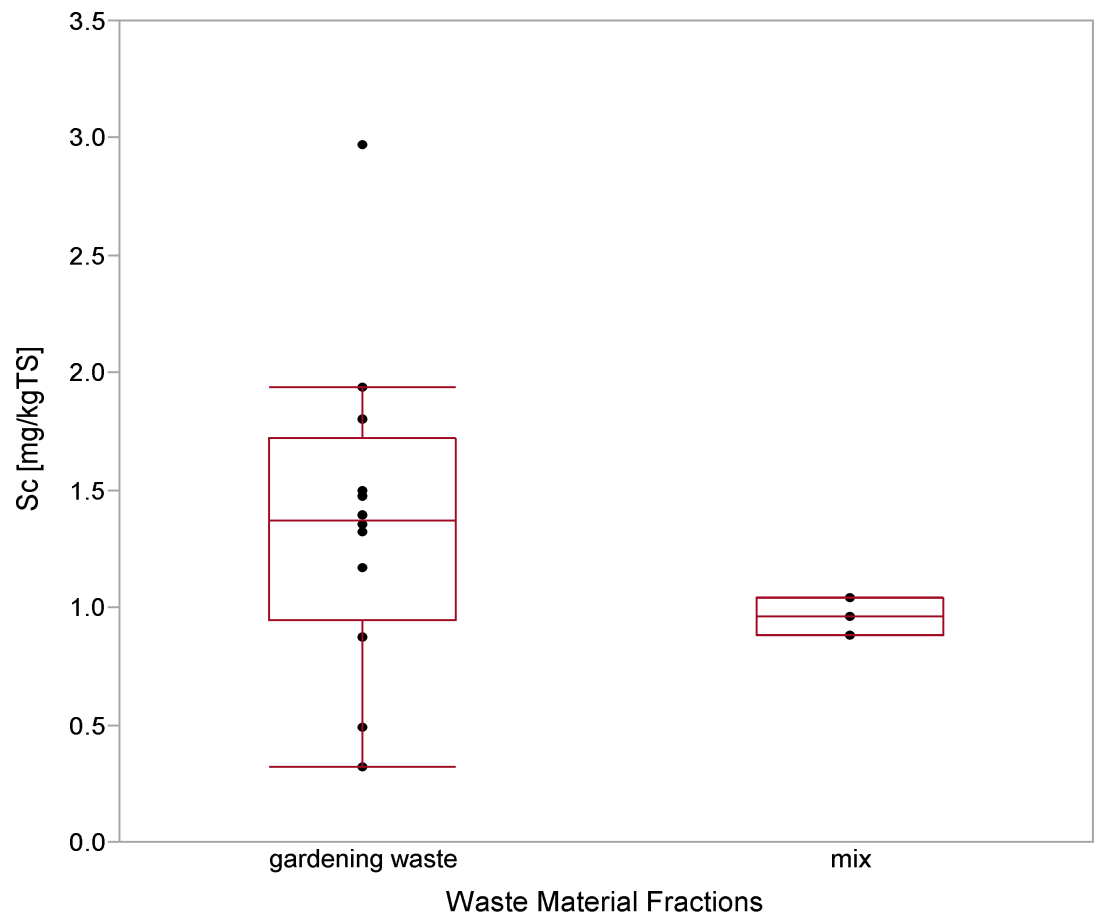

Quantiles [mg/kgTS]

\begin{tabular}{|c|c|c|c|c|c|c|c|c|c|}
\hline $\begin{array}{l}\text { Waste Material } \\
\text { Fraction }\end{array}$ & n_data* & $n_{-}<D L^{* *}$ & Min & $10 \%$ & $25 \%$ & Median & $75 \%$ & $90 \%$ & Max \\
\hline organic & - & - & - & - & - & - & - & - & - \\
\hline food waste & - & - & - & - & - & - & - & - & - \\
\hline gardening waste & 12 & & 0.32 & 0.37 & 0.95 & 1.37 & 1.73 & 2.66 & 2.97 \\
\hline paper \& cardboard & - & - & - & - & - & - & - & - & - \\
\hline composites & - & - & - & - & - & - & - & - & - \\
\hline plastic & - & - & - & - & - & - & - & - & - \\
\hline combustibles & - & - & - & - & - & - & - & - & - \\
\hline metal & - & - & - & - & - & - & - & - & - \\
\hline glass & - & - & - & - & - & - & - & - & - \\
\hline inert & - & - & - & - & - & - & - & - & - \\
\hline $\operatorname{mix}$ & 3 & & 0.88 & 0.88 & 0.88 & 0.96 & 1.04 & 1.04 & 1.04 \\
\hline Total & 15 & 0 & & & & & & & \\
\hline
\end{tabular}




\section{Value ranges for Se}

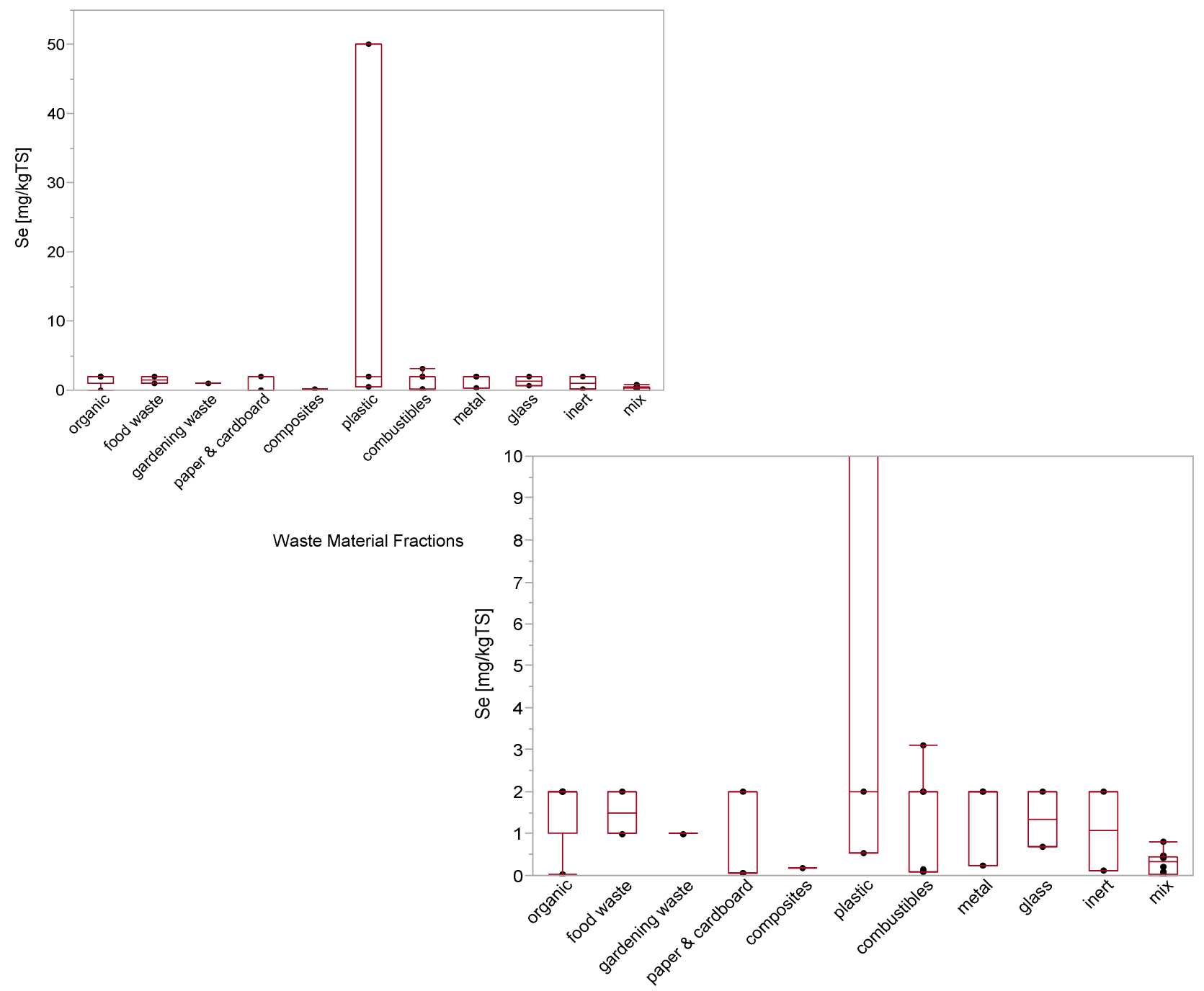

\section{Quantiles [mg/kgTS]}

Waste Material Fractions

\begin{tabular}{|c|c|c|c|c|c|c|c|c|c|}
\hline $\begin{array}{c}\text { Waste Material } \\
\text { Fraction }\end{array}$ & n_data* & $\mathrm{n}_{-}<\mathrm{DL}$ ** & Min & $10 \%$ & $25 \%$ & Median & $75 \%$ & $90 \%$ & Max \\
\hline organic & 5 & 4 & 0.04 & 0.04 & 1.02 & 2.00 & 2.00 & 2.00 & 2.00 \\
\hline food waste & 2 & 2 & 1.00 & 1.00 & 1.00 & 1.50 & 2.00 & 2.00 & 2.00 \\
\hline gardening waste & 1 & 1 & 1.00 & 1.00 & 1.00 & 1.00 & 1.00 & 1.00 & 1.00 \\
\hline paper \& cardboard & 3 & 1 & 0.06 & 0.06 & 0.06 & 0.07 & 2.00 & 2.00 & 2.00 \\
\hline composites & 1 & - & 0.17 & 0.17 & 0.17 & 0.17 & 0.17 & 0.17 & 0.17 \\
\hline plastic & 3 & 2 & 0.55 & 0.55 & 0.55 & 2.00 & 50.00 & 50.00 & 50.00 \\
\hline combustibles & 7 & 3 & 0.08 & 0.08 & 0.10 & 2.00 & 2.00 & 3.10 & 3.10 \\
\hline metal & 3 & 2 & 0.25 & 0.25 & 0.25 & 2.00 & 2.00 & 2.00 & 2.00 \\
\hline glass & 2 & 1 & 0.69 & 0.69 & 0.69 & 1.35 & 2.00 & 2.00 & 2.00 \\
\hline inert & 2 & 1 & 0.12 & 0.12 & 0.12 & 1.06 & 2.00 & 2.00 & 2.00 \\
\hline $\operatorname{mix}$ & 10 & - & 0.00 & 0.00 & 0.02 & 0.32 & 0.46 & 0.77 & 0.80 \\
\hline
\end{tabular}

*) number of data points

${ }^{* *}$ ) number of values below the detection limit 
Value ranges for $\mathrm{Si}$

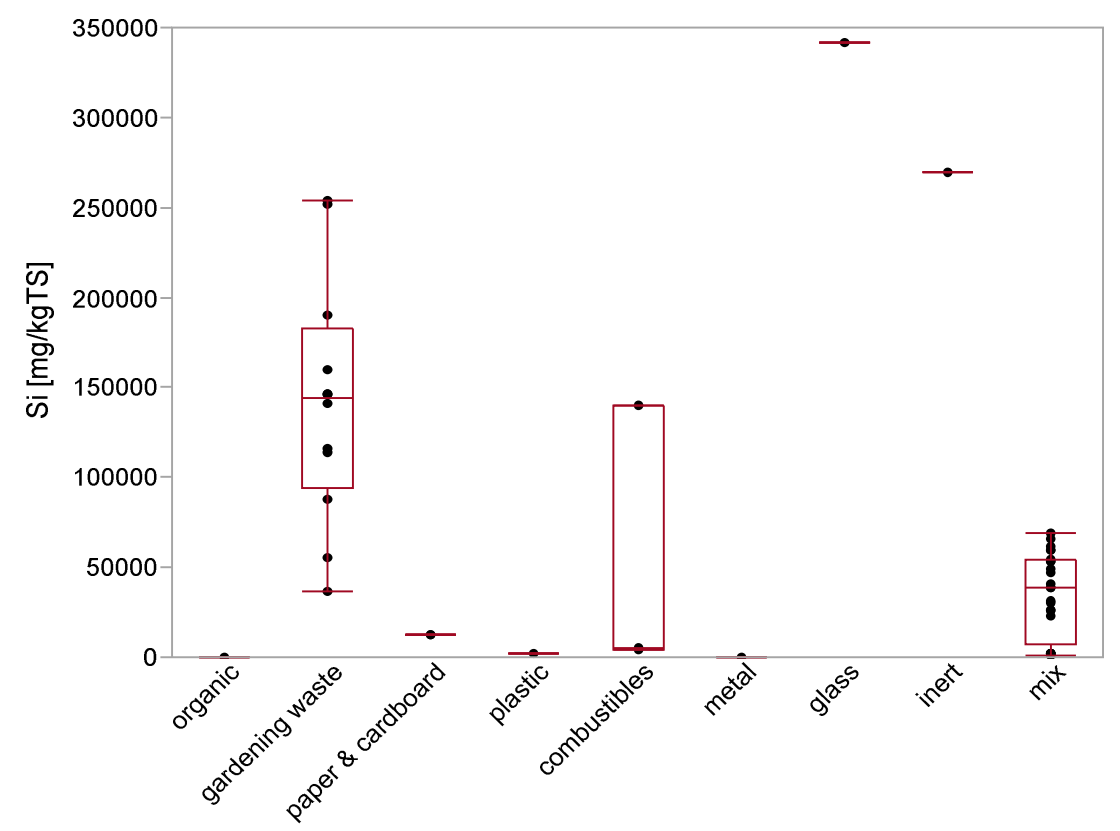

Waste Material Fractions

\section{Quantiles [mg/kgTS]}

\begin{tabular}{|c|c|c|c|c|c|c|c|c|c|}
\hline $\begin{array}{l}\text { Waste Material } \\
\text { Fraction }\end{array}$ & n_data* & $\mathrm{n}_{-}<\mathrm{DL}$ ** & Min & $10 \%$ & $25 \%$ & Median & $75 \%$ & $90 \%$ & $\operatorname{Max}$ \\
\hline organic & 1 & - & 488 & 488 & 488 & 488 & 488 & 488 & 488 \\
\hline food waste & - & - & - & - & - & - & - & - & - \\
\hline gardening waste & 12 & - & 37000 & 42400 & 94283 & 143733 & 182500 & 253663 & 254393 \\
\hline paper \& cardboard & 2 & - & 12200 & 12200 & 12200 & 12400 & 12600 & 12600 & 12600 \\
\hline composites & - & - & - & - & - & - & - & - & - \\
\hline plastic & 1 & - & 1670 & 1670 & 1670 & 1670 & 1670 & 1670 & 1670 \\
\hline combustibles & 3 & - & 3980 & 3980 & 3980 & 5110 & 140000 & 140000 & 140000 \\
\hline metal & 1 & - & 168 & 168 & 168 & 168 & 168 & 168 & 168 \\
\hline glass & 1 & - & 342000 & 342000 & 342000 & 342000 & 342000 & 342000 & 342000 \\
\hline inert & 1 & - & 270000 & 270000 & 270000 & 270000 & 270000 & 270000 & 270000 \\
\hline $\operatorname{mix}$ & 24 & - & 1447 & 1700 & 7443 & 38579 & 54480 & 64099 & 69200 \\
\hline
\end{tabular}

*) number of data points

$\left.{ }^{\star *}\right)$ number of values below the detection limit 


\section{Value ranges for Sn}

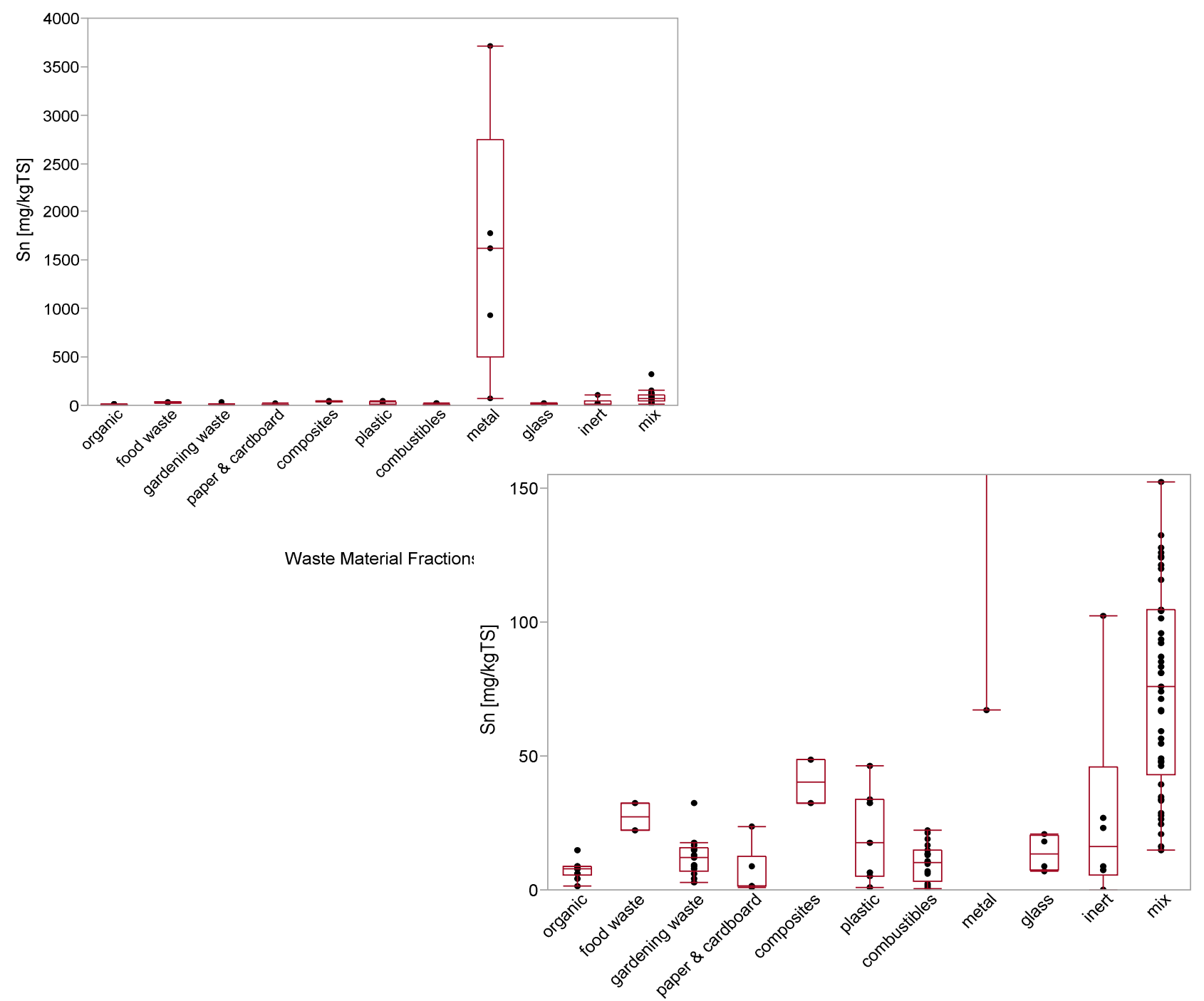

Quantiles [mg/kgTS]

Waste Material Fractions

\begin{tabular}{|c|c|c|c|c|c|c|c|c|c|}
\hline $\begin{array}{c}\text { Waste Material } \\
\text { Fraction }\end{array}$ & n_data* & $\mathrm{n}_{-}<\mathrm{DL} L^{* *}$ & Min & $10 \%$ & $25 \%$ & Median & $75 \%$ & $90 \%$ & $\operatorname{Max}$ \\
\hline organic & 10 & - & 1.2 & 1.5 & 5.6 & 8.0 & 8.9 & 14.1 & 14.7 \\
\hline food waste & 2 & - & 22.0 & 22.0 & 22.0 & 27.3 & 32.5 & 32.5 & 32.5 \\
\hline gardening waste & 13 & 4 & 3.0 & 3.4 & 7.1 & 12.0 & 15.9 & 26.4 & 32.2 \\
\hline paper \& cardboard & 6 & 1 & 1.0 & 1.0 & 1.2 & 1.4 & 12.6 & 23.5 & 23.5 \\
\hline composites & 2 & - & 32.3 & 32.3 & 32.3 & 40.4 & 48.5 & 48.5 & 48.5 \\
\hline plastic & 7 & 1 & 0.9 & 0.9 & 5.0 & 17.7 & 34.0 & 46.4 & 46.4 \\
\hline combustibles & 20 & 2 & 0.6 & 1.0 & 3.4 & 10.3 & 14.7 & 21.2 & 22.4 \\
\hline metal & 5 & 1 & 67.0 & 67.0 & 498.5 & 1620.0 & 2745.0 & 3710.0 & 3710.0 \\
\hline glass & 4 & - & 7.1 & 7.1 & 7.5 & 13.5 & 20.3 & 21.0 & 21.0 \\
\hline inert & 6 & - & 0.0 & 0.0 & 5.6 & 16.0 & 45.9 & 102.4 & 102.4 \\
\hline $\operatorname{mix}$ & 45 & - & 15.0 & 25.6 & 42.9 & 76.1 & 104.4 & 126.5 & 321.0 \\
\hline
\end{tabular}

*) number of data points

${ }^{* *}$ ) number of values below the detection limit 


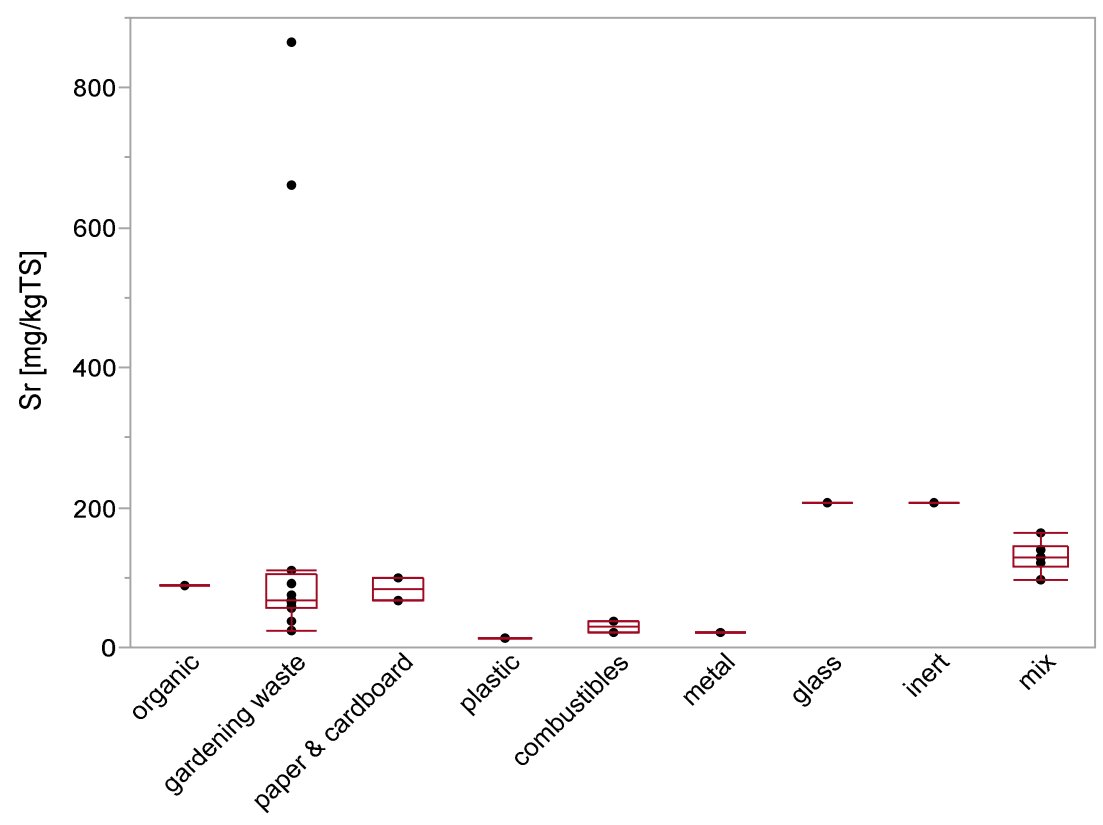

Waste Material Fractions

\section{Quantiles [mg/kgTS]}

\begin{tabular}{|c|c|c|c|c|c|c|c|c|c|}
\hline $\begin{array}{c}\text { Waste Material } \\
\text { Fraction }\end{array}$ & n_data* & $\mathrm{n}_{-}<\mathrm{DL}^{* *}$ & Min & $10 \%$ & $25 \%$ & Median & $75 \%$ & $90 \%$ & Max \\
\hline organic & 1 & - & 88.1 & 88.1 & 88.1 & 88.1 & 88.1 & 88.1 & 88.1 \\
\hline food waste & - & - & - & - & - & - & - & - & - \\
\hline gardening waste & 12 & - & 25.0 & 28.6 & 56.9 & 67.6 & 104.9 & 803.1 & 864.0 \\
\hline paper \& cardboard & 2 & - & 68.5 & 68.5 & 68.5 & 83.5 & 98.4 & 98.4 & 98.4 \\
\hline composites & - & - & - & - & - & - & - & - & - \\
\hline plastic & 1 & - & 13.3 & 13.3 & 13.3 & 13.3 & 13.3 & 13.3 & 13.3 \\
\hline combustibles & 2 & - & 20.9 & 20.9 & 20.9 & 29.0 & 37.0 & 37.0 & 37.0 \\
\hline metal & 1 & - & 21.5 & 21.5 & 21.5 & 21.5 & 21.5 & 21.5 & 21.5 \\
\hline glass & 1 & - & 208.0 & 208.0 & 208.0 & 208.0 & 208.0 & 208.0 & 208.0 \\
\hline inert & 1 & - & 208.0 & 208.0 & 208.0 & 208.0 & 208.0 & 208.0 & 208.0 \\
\hline $\operatorname{mix}$ & 6 & - & 97.0 & 97.0 & 115.0 & 130.0 & 145.0 & 163.0 & 163.0 \\
\hline
\end{tabular}

*) number of data points

$\left.{ }^{* *}\right)$ number of values below the detection limit 


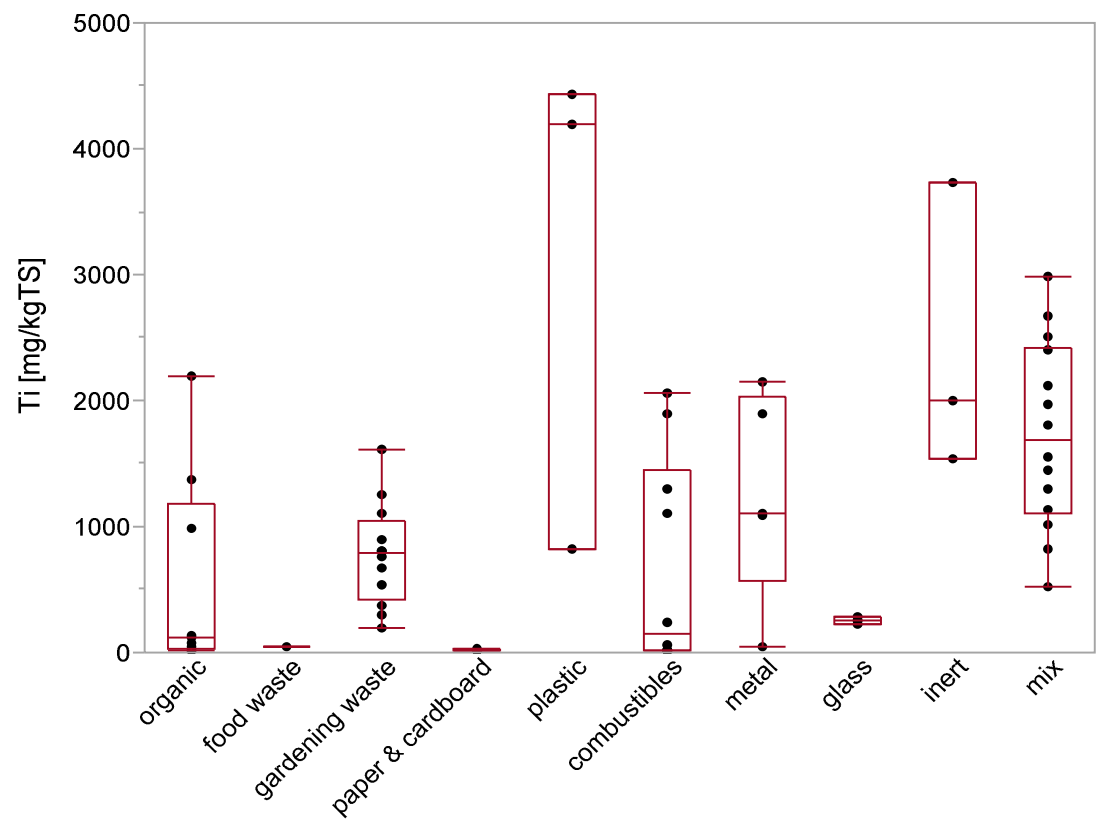

Waste Material Fractions

\section{Quantiles [mg/kgTS]}

\begin{tabular}{|c|c|c|c|c|c|c|c|c|c|}
\hline $\begin{array}{l}\text { Waste Material } \\
\text { Fraction }\end{array}$ & n_data* & $\mathrm{n}_{-}<\mathrm{DL} * *$ & Min & $10 \%$ & $25 \%$ & Median & $75 \%$ & $90 \%$ & Max \\
\hline organic & 9 & - & 8 & 8 & 34 & 120 & 1175 & 2200 & 2200 \\
\hline food waste & 1 & - & 45 & 45 & 45 & 45 & 45 & 45 & 45 \\
\hline gardening waste & 12 & - & 200 & 230 & 413 & 788 & 1050 & 1502 & 1607 \\
\hline paper \& cardboard & 4 & - & 10 & 10 & 10 & 13 & 30 & 34 & 34 \\
\hline composites & - & - & - & - & - & - & - & - & - \\
\hline plastic & 3 & - & 821 & 821 & 821 & 4200 & 4433 & 4433 & 4433 \\
\hline combustibles & 10 & - & 8 & 8 & 13 & 150 & 1450 & 2050 & 2067 \\
\hline metal & 5 & - & 46 & 46 & 568 & 1100 & 2025 & 2150 & 2150 \\
\hline glass & 3 & - & 230 & 230 & 230 & 250 & 289 & 289 & 289 \\
\hline inert & 3 & - & 1533 & 1533 & 1533 & 2000 & 3730 & 3730 & 3730 \\
\hline $\operatorname{mix}$ & 14 & - & 529 & 673 & 1101 & 1680 & 2425 & 2833 & 2990 \\
\hline
\end{tabular}

*) number of data points

$\left.{ }^{\star *}\right)$ number of values below the detection limit 


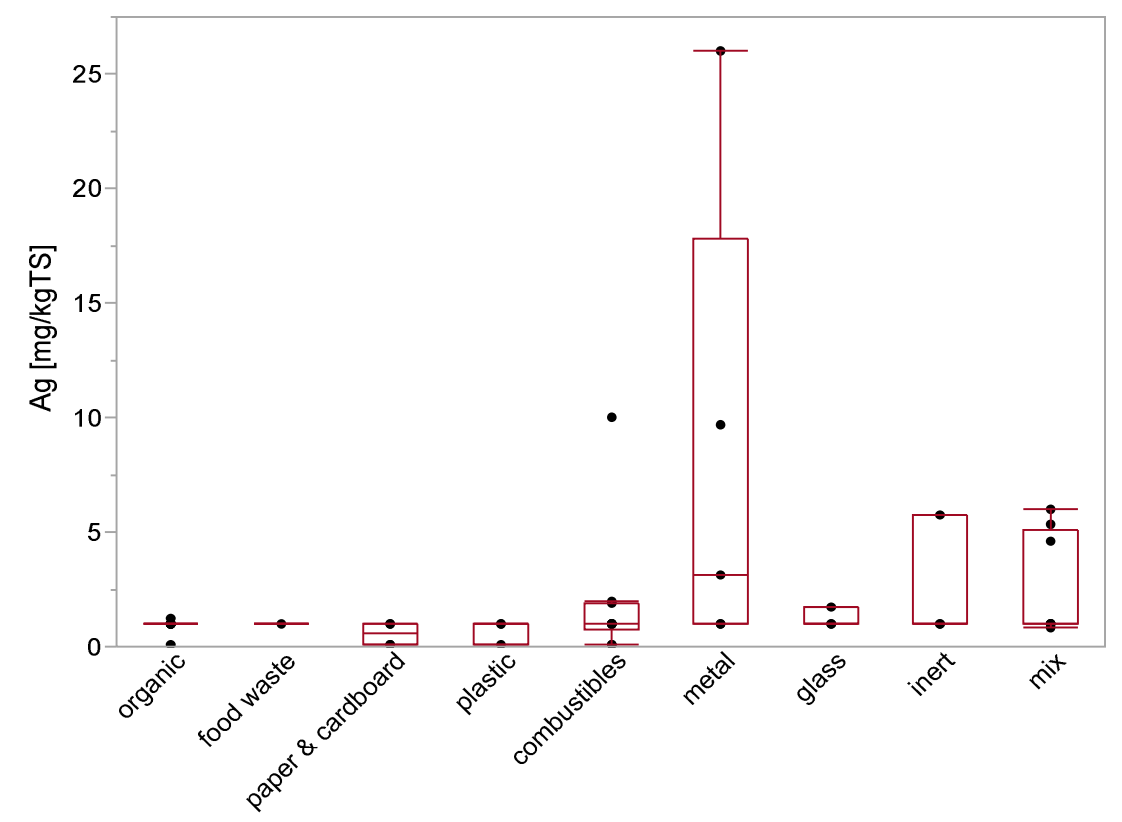

Waste Material Fractions

\section{Quantiles [mg/kgTS]}

\begin{tabular}{|c|c|c|c|c|c|c|c|c|c|}
\hline $\begin{array}{c}\text { Waste Material } \\
\text { Fraction }\end{array}$ & n_data* & $\mathrm{n}_{-}<\mathrm{DL} * *$ & Min & $10 \%$ & $25 \%$ & Median & $75 \%$ & $90 \%$ & Max \\
\hline organic & 9 & 7 & 0.08 & 0.08 & 1.00 & 1.00 & 1.00 & 1.20 & 1.20 \\
\hline food waste & 1 & 1 & 1.00 & 1.00 & 1.00 & 1.00 & 1.00 & 1.00 & 1.00 \\
\hline gardening waste & - & - & - & - & - & - & - & - & - \\
\hline paper \& cardboard & 4 & 3 & 0.08 & 0.08 & 0.09 & 0.56 & 1.00 & 1.00 & 1.00 \\
\hline composites & - & - & - & - & - & - & - & - & - \\
\hline plastic & 3 & 3 & 0.08 & 0.08 & 0.08 & 1.00 & 1.00 & 1.00 & 1.00 \\
\hline combustibles & 10 & 7 & 0.08 & 0.08 & 0.77 & 1.00 & 1.93 & 9.20 & 10.00 \\
\hline metal & 5 & 4 & 1.00 & 1.00 & 1.00 & 3.14 & 17.85 & 26.00 & 26.00 \\
\hline glass & 3 & 2 & 1.00 & 1.00 & 1.00 & 1.00 & 1.71 & 1.71 & 1.71 \\
\hline inert & 3 & 2 & 1.00 & 1.00 & 1.00 & 1.00 & 5.78 & 5.78 & 5.78 \\
\hline $\operatorname{mix}$ & 8 & 4 & 0.86 & 0.86 & 1.00 & 1.00 & 5.12 & 6.02 & 6.02 \\
\hline Total & 46 & 33 & & & & & & & \\
\hline
\end{tabular}




\section{Value ranges for $\mathrm{Al}$}

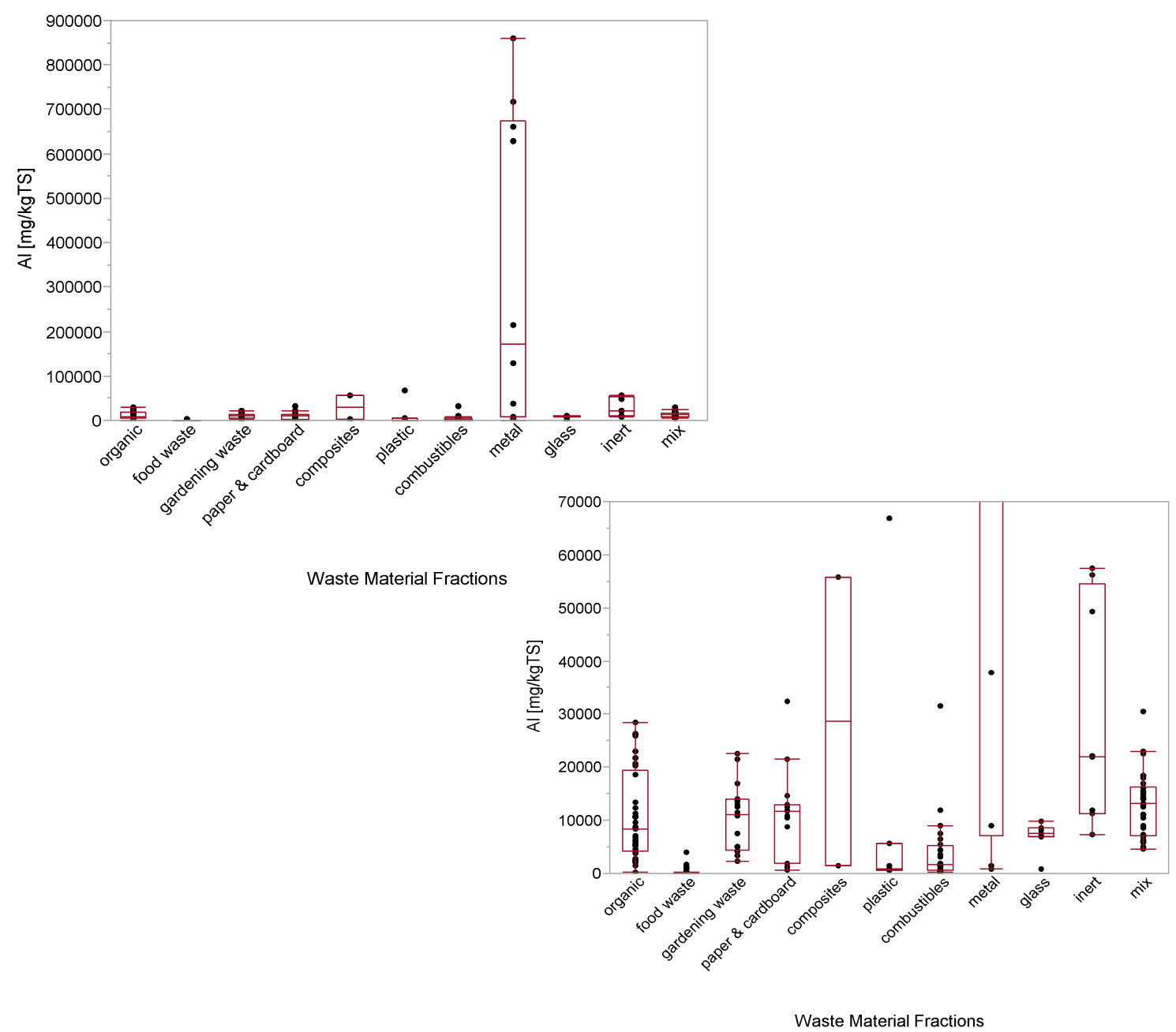

Quantiles [mg/kgTS]

\begin{tabular}{|c|c|c|c|c|c|c|c|c|c|}
\hline $\begin{array}{l}\text { Waste Material } \\
\text { Fraction }\end{array}$ & n_data* & $\mathbf{n}_{-}<\mathrm{DL}^{* *}$ & Min & $10 \%$ & $25 \%$ & Median & $75 \%$ & $90 \%$ & Max \\
\hline organic & 41 & - & 286 & 2160 & 4100 & 8400 & 19464 & 25412 & 28333 \\
\hline food waste & 47 & - & 12 & 21 & 30 & 46 & 103 & 851 & 3890 \\
\hline gardening waste & 16 & - & 2360 & 3088 & 4453 & 11178 & 13916 & 21859 & 22550 \\
\hline paper \& cardboard & 15 & - & 681 & 1033 & 1800 & 11700 & 12933 & 25870 & 32425 \\
\hline composites & 2 & - & 1430 & 1430 & 1430 & 28615 & 55800 & 55800 & 55800 \\
\hline plastic & 7 & - & 692 & 692 & 720 & 820 & 5650 & 66800 & 66800 \\
\hline combustibles & 24 & - & 200 & 250 & 678 & 1570 & 5150 & 10500 & 31600 \\
\hline metal & 10 & - & 860 & 926 & 7055 & 171500 & 674500 & 846700 & 861000 \\
\hline glass & 7 & - & 750 & 750 & 6860 & 7620 & 8470 & 9870 & 9870 \\
\hline inert & 8 & - & 7300 & 7300 & 11361 & 22000 & 54483 & 57500 & 57500 \\
\hline mix & 34 & - & 4670 & 5435 & 7118 & 13080 & 16280 & 20478 & 30500 \\
\hline
\end{tabular}

Grand Total

209

*) number of data points

$\left.{ }^{\star \star}\right)$ number of values below the detection limit 


\section{Value ranges for As}

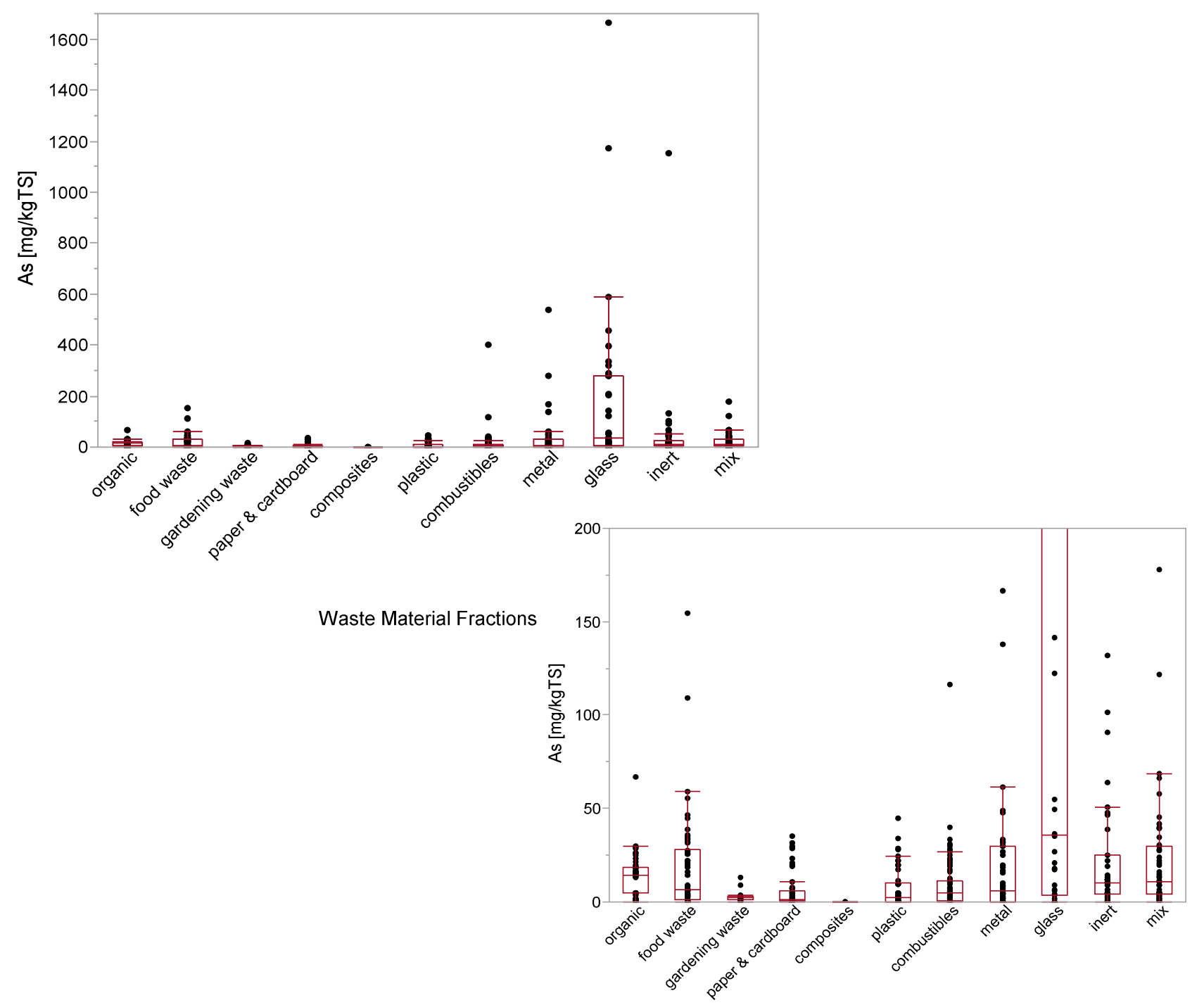

\section{Quantiles [mg/kgTS]}

\begin{tabular}{|c|c|c|c|c|c|c|c|c|c|}
\hline \multirow{2}{*}{$\begin{array}{c}\text { Waste Material } \\
\text { Fraction }\end{array}$} & \multirow[b]{2}{*}{ n_data* } & \multirow[b]{2}{*}{$\mathrm{n}_{-}<\mathrm{DL} * *$} & \multirow[b]{2}{*}{ Min } & \multicolumn{6}{|c|}{ Waste Material Fractions } \\
\hline & & & & $10 \%$ & $25 \%$ & Median & $75 \%$ & $90 \%$ & $\operatorname{Max}$ \\
\hline organic & 48 & 8 & 0.200 & 0.699 & 5.000 & 14.565 & 18.605 & 26.385 & 67.000 \\
\hline food waste & 54 & 1 & 0.000 & 0.000 & 1.000 & 6.750 & 28.350 & 45.550 & 154.400 \\
\hline gardening waste & 18 & - & 0.000 & 0.495 & 1.188 & 2.405 & 3.080 & 9.582 & 13.020 \\
\hline paper \& cardboard & 57 & 4 & 0.000 & 0.126 & 0.345 & 1.090 & 6.100 & 24.100 & 35.100 \\
\hline composites & 3 & - & 0.140 & 0.140 & 0.140 & 0.200 & 0.200 & 0.200 & 0.200 \\
\hline plastic & 46 & 5 & 0.000 & 0.000 & 0.215 & 2.250 & 10.075 & 25.580 & 44.800 \\
\hline combustibles & 89 & 10 & 0.000 & 0.000 & 0.305 & 5.000 & 11.340 & 28.170 & 400.000 \\
\hline metal & 45 & 1 & 0.000 & 0.000 & 0.000 & 6.200 & 29.800 & 92.040 & 539.000 \\
\hline glass & 36 & - & 0.000 & 0.000 & 3.800 & 35.900 & 280.475 & 497.680 & 1664.400 \\
\hline inert & 39 & 2 & 0.000 & 0.000 & 4.000 & 10.400 & 25.000 & 91.000 & 1153.000 \\
\hline $\operatorname{mix}$ & 50 & 2 & 0.000 & 1.633 & 4.060 & 10.950 & 30.068 & 56.465 & 177.990 \\
\hline
\end{tabular}

*) number of data points

${ }^{* *}$ ) number of values below the detection limit 


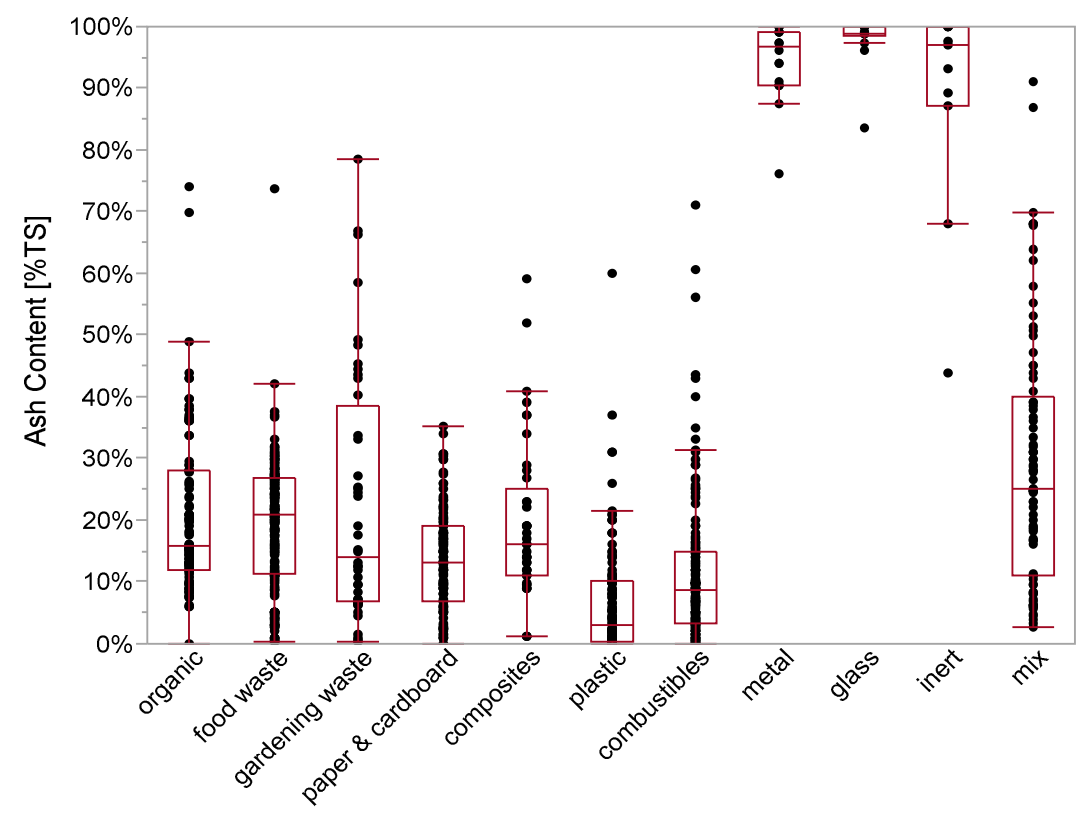

Waste Material Fractions

\section{Quantiles [\%TS]}

\begin{tabular}{|c|c|c|c|c|c|c|c|c|c|}
\hline $\begin{array}{l}\text { Waste Material } \\
\text { Fraction }\end{array}$ & n_data* & $\mathrm{n}_{-}<\mathrm{DL}$ ** & Min & $10 \%$ & $25 \%$ & Median & $75 \%$ & $90 \%$ & Max \\
\hline organic & 106 & - & $0.0 \%$ & $8.5 \%$ & $12.0 \%$ & $15.7 \%$ & $28.0 \%$ & $38.0 \%$ & $74.0 \%$ \\
\hline food waste & 196 & - & $0.2 \%$ & $3.8 \%$ & $11.5 \%$ & $20.9 \%$ & $26.9 \%$ & $30.0 \%$ & $73.7 \%$ \\
\hline gardening waste & 44 & - & $0.4 \%$ & $3.0 \%$ & $6.8 \%$ & $14.0 \%$ & $38.6 \%$ & $53.9 \%$ & $78.4 \%$ \\
\hline paper \& cardboard & 112 & - & $0.0 \%$ & $2.4 \%$ & $6.8 \%$ & $13.0 \%$ & $19.0 \%$ & $25.7 \%$ & $35.4 \%$ \\
\hline composites & 41 & - & $1.2 \%$ & $9.0 \%$ & $11.0 \%$ & $16.0 \%$ & $25.0 \%$ & $38.6 \%$ & $59.0 \%$ \\
\hline plastic & 119 & - & $0.0 \%$ & $0.1 \%$ & $0.4 \%$ & $3.0 \%$ & $10.0 \%$ & $18.0 \%$ & $60.0 \%$ \\
\hline combustibles & 146 & - & $0.0 \%$ & $1.0 \%$ & $3.2 \%$ & $8.7 \%$ & $15.1 \%$ & $26.6 \%$ & $71.0 \%$ \\
\hline metal & 18 & - & $76.1 \%$ & $86.5 \%$ & $90.5 \%$ & $96.7 \%$ & $99.3 \%$ & $100.0 \%$ & $100.0 \%$ \\
\hline glass & 14 & - & $83.5 \%$ & $89.8 \%$ & $98.5 \%$ & $98.9 \%$ & $100.0 \%$ & $100.0 \%$ & $100.0 \%$ \\
\hline inert & 11 & - & $43.9 \%$ & $48.7 \%$ & $87.2 \%$ & $97.0 \%$ & $100.0 \%$ & $100.0 \%$ & $100.0 \%$ \\
\hline $\operatorname{mix}$ & 85 & - & $2.6 \%$ & $6.1 \%$ & $11.0 \%$ & $25.0 \%$ & $39.9 \%$ & $62.8 \%$ & $91.0 \%$ \\
\hline
\end{tabular}

*) number of data points

${ }^{* *}$ ) number of values below the detection limit 


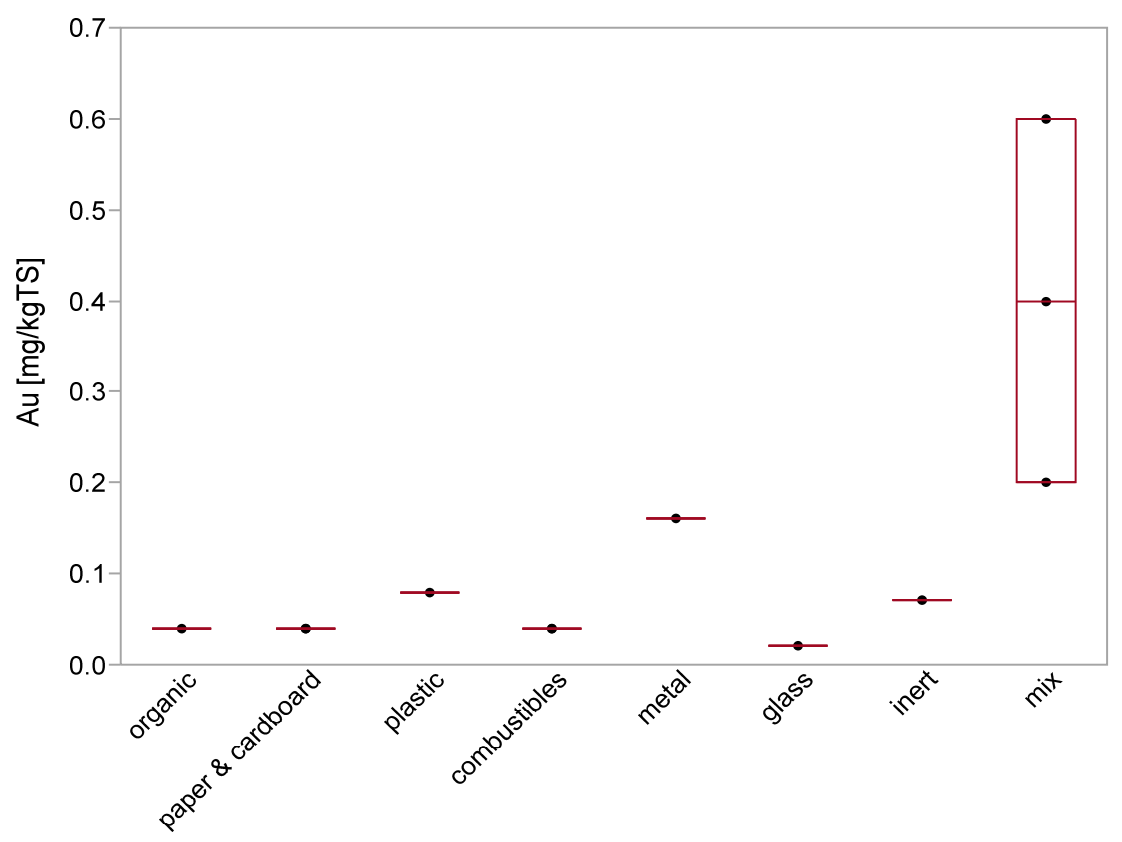

Waste Material Fractions

\section{Quantiles [mg/kgTS]}

\begin{tabular}{|c|c|c|c|c|c|c|c|c|c|}
\hline $\begin{array}{c}\text { Waste Material } \\
\text { Fraction }\end{array}$ & n_data* & $\mathrm{n}_{-}<\mathrm{DL} \mathbf{L}^{* *}$ & Min & $10 \%$ & $25 \%$ & Median & $75 \%$ & $90 \%$ & Max \\
\hline organic & 1 & 1 & 0.04 & 0.04 & 0.04 & 0.04 & 0.04 & 0.04 & 0.04 \\
\hline food waste & - & - & - & - & - & - & - & - & - \\
\hline gardening waste & - & - & - & - & - & - & - & - & - \\
\hline paper \& cardboard & 2 & 2 & 0.04 & 0.04 & 0.04 & 0.04 & 0.04 & 0.04 & 0.04 \\
\hline composites & - & - & - & - & - & - & - & - & - \\
\hline plastic & 1 & 1 & 0.08 & 0.08 & 0.08 & 0.08 & 0.08 & 0.08 & 0.08 \\
\hline combustibles & 2 & 2 & 0.04 & 0.04 & 0.04 & 0.04 & 0.04 & 0.04 & 0.04 \\
\hline metal & 1 & - & 0.16 & 0.16 & 0.16 & 0.16 & 0.16 & 0.16 & 0.16 \\
\hline glass & 1 & 1 & 0.02 & 0.02 & 0.02 & 0.02 & 0.02 & 0.02 & 0.02 \\
\hline inert & 1 & - & 0.07 & 0.07 & 0.07 & 0.07 & 0.07 & 0.07 & 0.07 \\
\hline $\operatorname{mix}$ & 3 & - & 0.20 & 0.20 & 0.20 & 0.40 & 0.60 & 0.60 & 0.60 \\
\hline
\end{tabular}

*) number of data points

$\left.{ }^{\star *}\right)$ number of values below the detection limit 


\section{Value ranges for $B$}

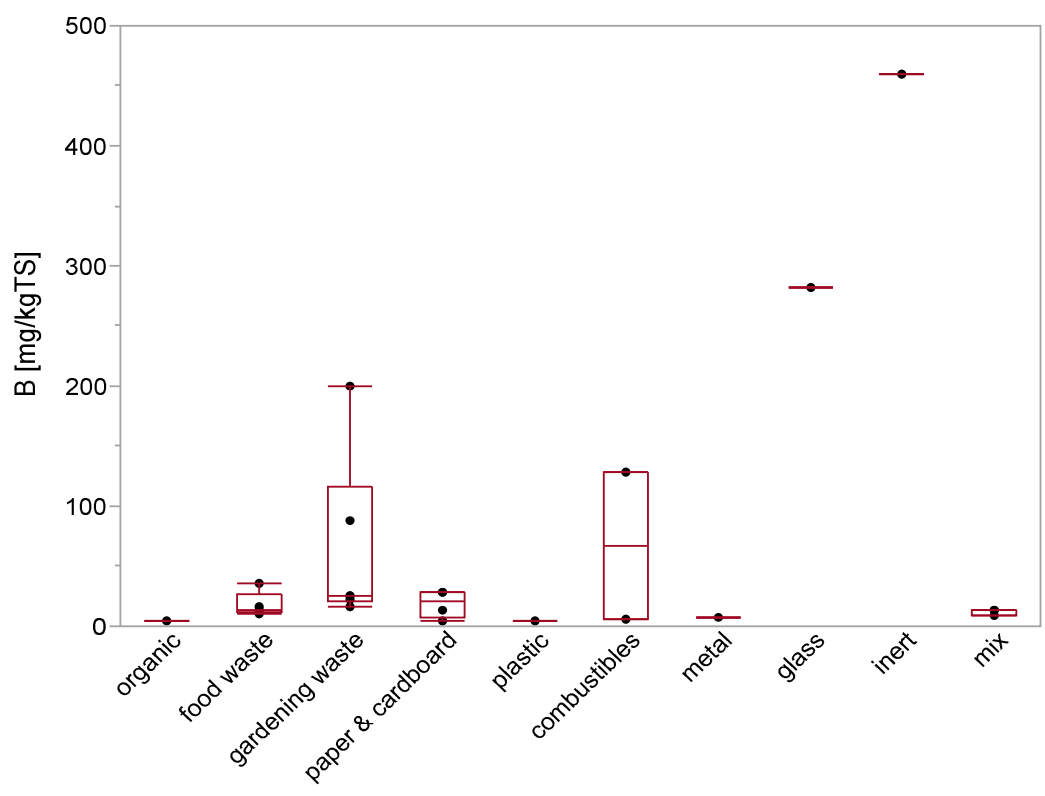

Waste Material Fractions

\section{Quantiles [mg/kgTS]}

\begin{tabular}{|c|c|c|c|c|c|c|c|c|c|}
\hline $\begin{array}{c}\text { Waste Material } \\
\text { Fraction }\end{array}$ & n_data* & $\mathrm{n}_{-}<\mathrm{DL}$ ** & Min & $10 \%$ & $25 \%$ & Median & $75 \%$ & $90 \%$ & Max \\
\hline organic & 1 & - & 5.1 & 5.1 & 5.1 & 5.1 & 5.1 & 5.1 & 5.1 \\
\hline food waste & 5 & - & 11.0 & 11.0 & 11.5 & 13.0 & 26.5 & 36.0 & 36.0 \\
\hline gardening waste & 6 & - & 17.0 & 17.0 & 20.8 & 25.5 & 116.0 & 200.0 & 200.0 \\
\hline paper \& cardboard & 4 & - & 4.6 & 4.6 & 6.9 & 21.0 & 28.5 & 28.7 & 28.7 \\
\hline composites & - & - & - & - & - & - & - & - & - \\
\hline plastic & 1 & - & 4.1 & 4.1 & 4.1 & 4.1 & 4.1 & 4.1 & 4.1 \\
\hline combustibles & 2 & - & 5.6 & 5.6 & 5.6 & 66.8 & 128.0 & 128.0 & 128.0 \\
\hline metal & 1 & - & 7.4 & 7.4 & 7.4 & 7.4 & 7.4 & 7.4 & 7.4 \\
\hline glass & 1 & - & 282.0 & 282.0 & 282.0 & 282.0 & 282.0 & 282.0 & 282.0 \\
\hline inert & 1 & - & 459.0 & 459.0 & 459.0 & 459.0 & 459.0 & 459.0 & 459.0 \\
\hline $\operatorname{mix}$ & 3 & - & 8.6 & 8.6 & 8.6 & 14.0 & 14.0 & 14.0 & 14.0 \\
\hline
\end{tabular}

$\left.{ }^{*}\right)$ number of data points

**) number of values below the detection limit 


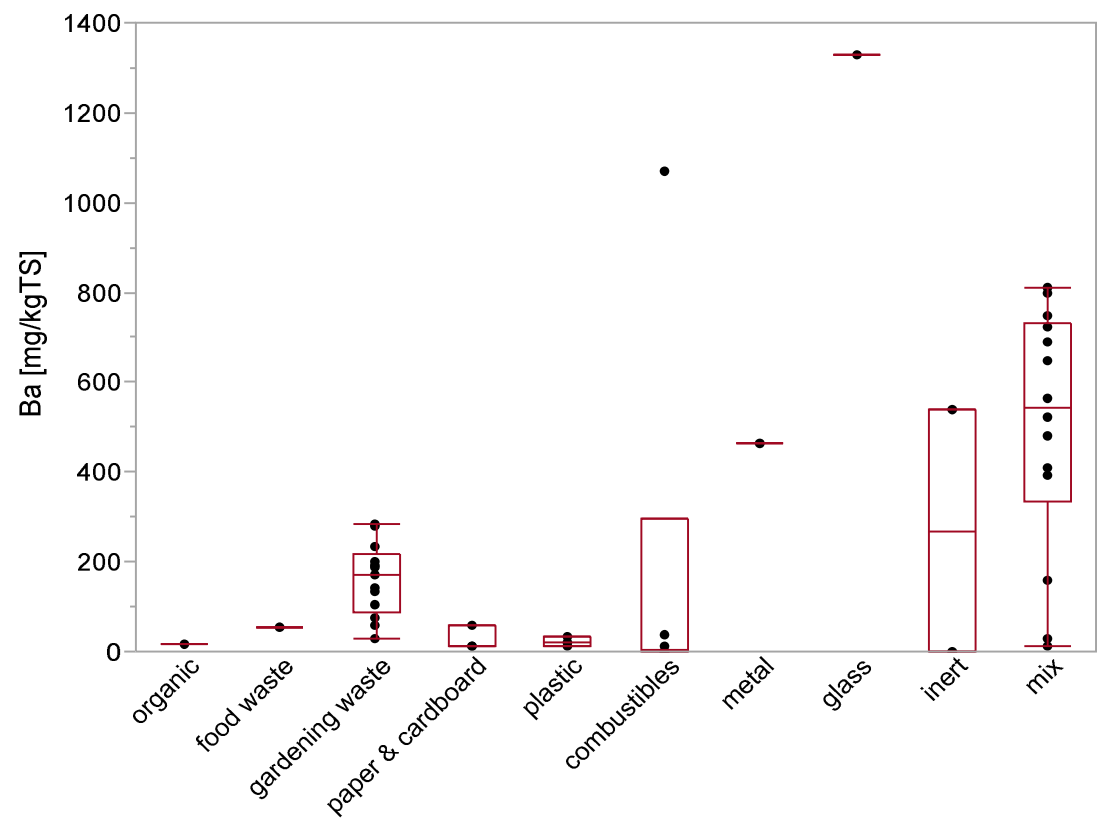

Waste Material Fractions

\section{Quantiles [mg/kgTS]}

\begin{tabular}{|c|c|c|c|c|c|c|c|c|c|}
\hline $\begin{array}{l}\text { Waste Material } \\
\text { Fraction }\end{array}$ & n_data* & $\mathbf{n}_{-}<\mathrm{DL}^{* *}$ & Min & $10 \%$ & $25 \%$ & Median & $75 \%$ & $90 \%$ & Max \\
\hline organic & 1 & - & 18.1 & 18.1 & 18.1 & 18.1 & 18.1 & 18.1 & 18.1 \\
\hline food waste & 1 & - & 55.1 & 55.1 & 55.1 & 55.1 & 55.1 & 55.1 & 55.1 \\
\hline gardening waste & 13 & - & 27.8 & 39.5 & 89.1 & 170.2 & 216.1 & 282.7 & 283.3 \\
\hline paper \& cardboard & 3 & - & 12.3 & 12.3 & 12.3 & 12.5 & 60.1 & 60.1 & 60.1 \\
\hline composites & - & - & - & - & - & - & - & - & - \\
\hline plastic & 3 & - & 12.8 & 12.8 & 12.8 & 22.5 & 33.4 & 33.4 & 33.4 \\
\hline combustibles & 6 & - & 0.0 & 0.0 & 0.0 & 5.3 & 297.5 & 1071.0 & 1071.0 \\
\hline metal & 1 & - & 464.0 & 464.0 & 464.0 & 464.0 & 464.0 & 464.0 & 464.0 \\
\hline glass & 1 & - & 1330.0 & 1330.0 & 1330.0 & 1330.0 & 1330.0 & 1330.0 & 1330.0 \\
\hline inert & 2 & - & 0.0 & 0.0 & 0.0 & 269.5 & 539.0 & 539.0 & 539.0 \\
\hline $\operatorname{mix}$ & 14 & - & 13.6 & 21.0 & 335.8 & 543.5 & 730.0 & 804.5 & 809.0 \\
\hline Grand Total & 45 & 0 & & & & & & & \\
\hline
\end{tabular}




\section{Value ranges for $\mathrm{Be}$}

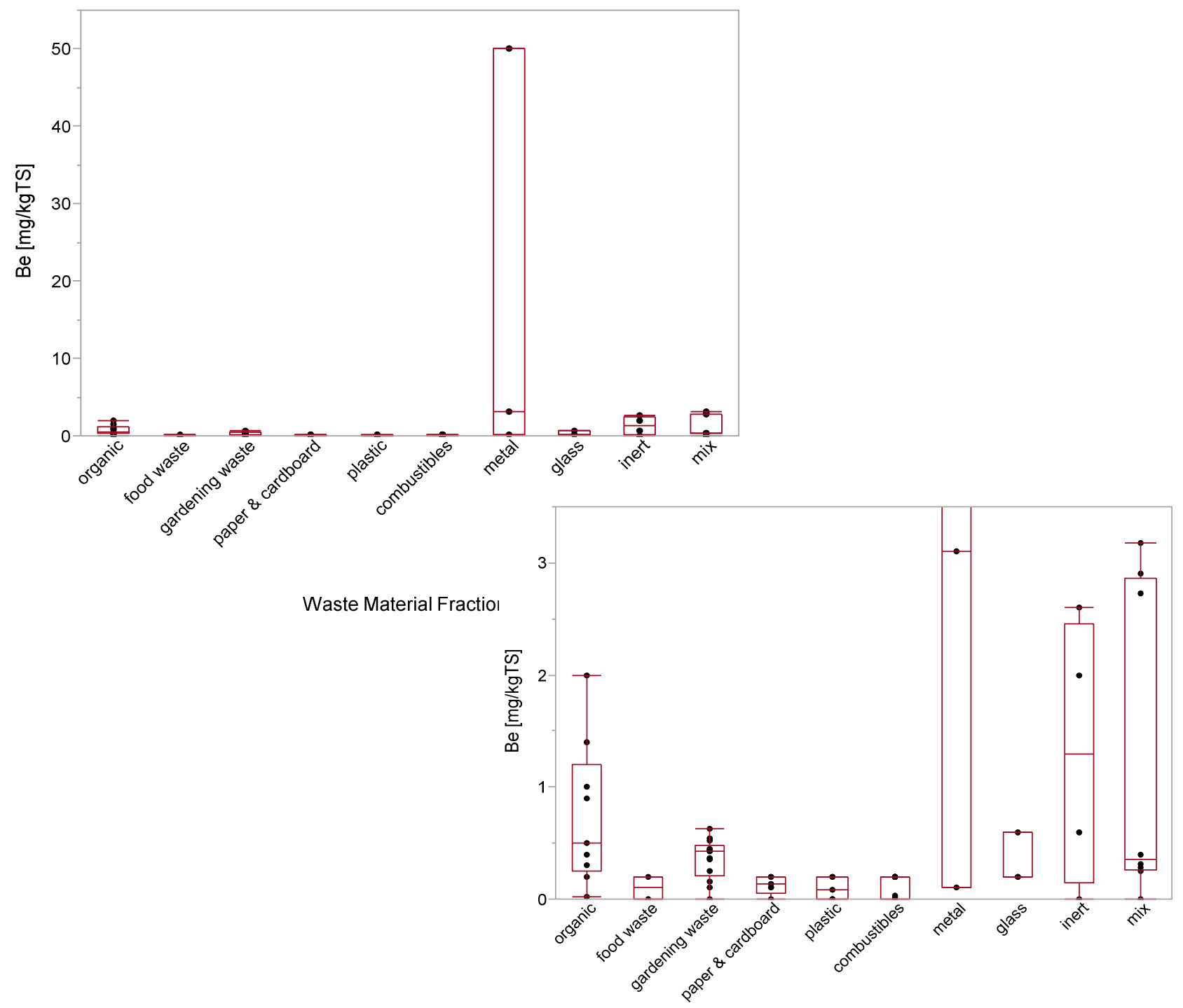

\section{Quantiles [mg/kgTS]}

Waste Material Fractions

\begin{tabular}{|c|c|c|c|c|c|c|c|c|c|}
\hline $\begin{array}{c}\text { Waste Material } \\
\text { Fraction }\end{array}$ & n_data* & $n \_<D L^{* *}$ & Min & $10 \%$ & $25 \%$ & Median & $75 \%$ & $90 \%$ & Max \\
\hline organic & 9 & 1 & 0.02 & 0.02 & 0.25 & 0.50 & 1.20 & 2.00 & 2.00 \\
\hline food waste & 2 & - & 0.00 & 0.00 & 0.00 & 0.10 & 0.20 & 0.20 & 0.20 \\
\hline gardening waste & 13 & - & 0.00 & 0.04 & 0.21 & 0.43 & 0.49 & 0.59 & 0.63 \\
\hline paper \& cardboard & 5 & - & 0.00 & 0.00 & 0.05 & 0.14 & 0.20 & 0.20 & 0.20 \\
\hline composites & - & - & - & - & - & - & - & - & - \\
\hline plastic & 5 & 1 & 0.00 & 0.00 & 0.00 & 0.08 & 0.20 & 0.20 & 0.20 \\
\hline combustibles & 14 & & 0.00 & 0.00 & 0.00 & 0.20 & 0.20 & 0.20 & 0.20 \\
\hline metal & 3 & 1 & 0.10 & 0.10 & 0.10 & 3.10 & 50.00 & 50.00 & 50.00 \\
\hline glass & 3 & - & 0.20 & 0.20 & 0.20 & 0.20 & 0.60 & 0.60 & 0.60 \\
\hline inert & 4 & - & 0.00 & 0.00 & 0.15 & 1.30 & 2.45 & 2.60 & 2.60 \\
\hline $\operatorname{mix}$ & 8 & - & 0.00 & 0.00 & 0.26 & 0.36 & 2.86 & 3.18 & 3.18 \\
\hline
\end{tabular}

*) number of data points

${ }^{* *}$ ) number of values below the detection limit 


\section{Value ranges for $\mathrm{Br}$}

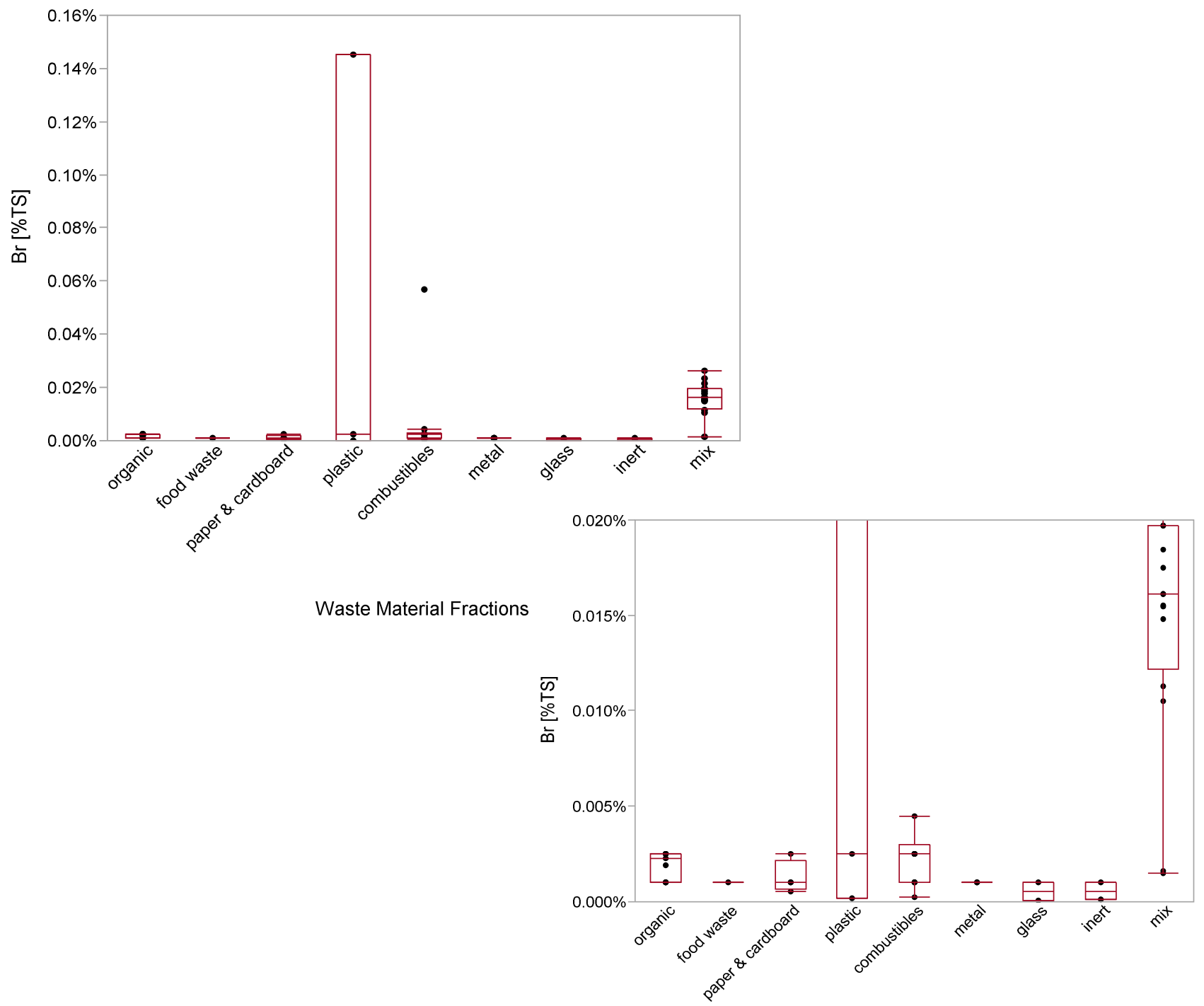

Quantiles [\%TS]

Waste Material Fractions

\section{Waste Material}

\begin{tabular}{|c|c|c|c|c|c|c|c|c|c|}
\hline Fraction & n_data* & $\mathrm{n} \_\mathrm{DL}^{* *}$ & Min & $10 \%$ & $25 \%$ & Median & $75 \%$ & $90 \%$ & Max \\
\hline organic & 9 & 7 & $0.001 \%$ & $0.001 \%$ & $0.001 \%$ & $0.002 \%$ & $0.003 \%$ & $0.003 \%$ & $0.003 \%$ \\
\hline food waste & 1 & 1 & $0.001 \%$ & $0.001 \%$ & $0.001 \%$ & $0.001 \%$ & $0.001 \%$ & $0.001 \%$ & $0.001 \%$ \\
\hline gardening waste & - & - & - & - & - & - & - & - & - \\
\hline paper \& cardboard & 4 & 2 & $0.001 \%$ & $0.001 \%$ & $0.001 \%$ & $0.001 \%$ & $0.002 \%$ & $0.003 \%$ & $0.003 \%$ \\
\hline composites & - & - & - & - & - & - & - & - & - \\
\hline plastic & 3 & 1 & $0.000 \%$ & $0.000 \%$ & $0.000 \%$ & $0.003 \%$ & $0.145 \%$ & $0.145 \%$ & $0.145 \%$ \\
\hline combustibles & 10 & 7 & $0.000 \%$ & $0.000 \%$ & $0.001 \%$ & $0.003 \%$ & $0.003 \%$ & $0.052 \%$ & $0.057 \%$ \\
\hline metal & 2 & 2 & $0.001 \%$ & $0.001 \%$ & $0.001 \%$ & $0.001 \%$ & $0.001 \%$ & $0.001 \%$ & $0.001 \%$ \\
\hline glass & 2 & 2 & $0.000 \%$ & $0.000 \%$ & $0.000 \%$ & $0.001 \%$ & $0.001 \%$ & $0.001 \%$ & $0.001 \%$ \\
\hline inert & 2 & 1 & $0.000 \%$ & $0.000 \%$ & $0.000 \%$ & $0.001 \%$ & $0.001 \%$ & $0.001 \%$ & $0.001 \%$ \\
\hline $\operatorname{mix}$ & 16 & 1 & $0.002 \%$ & $0.002 \%$ & $0.012 \%$ & $0.016 \%$ & $0.020 \%$ & $0.024 \%$ & $0.026 \%$ \\
\hline
\end{tabular}

*) number of data points

${ }^{* *}$ ) number of values below the detection limit 


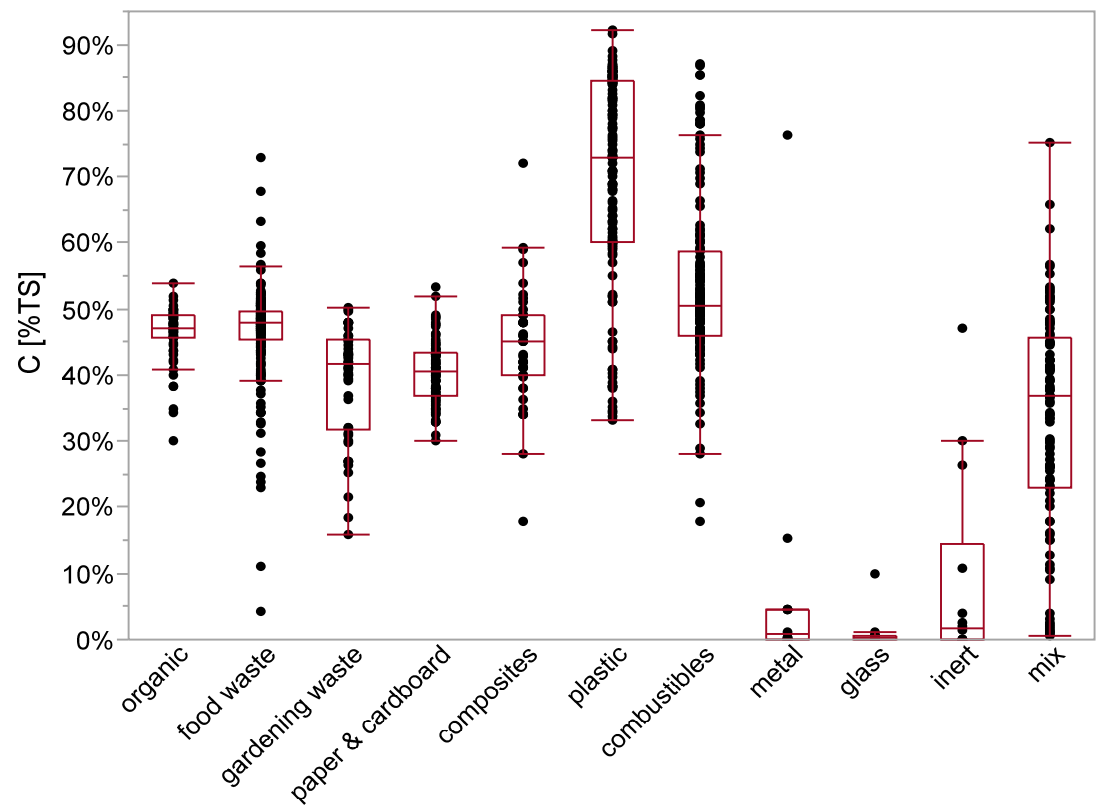

Waste Material Fractions

\section{Quantiles [\%TS]}

\begin{tabular}{|c|c|c|c|c|c|c|c|c|c|}
\hline $\begin{array}{c}\text { Waste Material } \\
\text { Fraction }\end{array}$ & n_data* & $\mathrm{n}_{-}<\mathrm{DL} * *$ & Min & $10 \%$ & $25 \%$ & Median & $75 \%$ & $90 \%$ & Max \\
\hline organic & 61 & - & $30.0 \%$ & $40.2 \%$ & $45.6 \%$ & $47.2 \%$ & $49.0 \%$ & $50.0 \%$ & $54.0 \%$ \\
\hline food waste & 211 & - & $4.4 \%$ & $39.5 \%$ & $45.2 \%$ & $47.9 \%$ & $49.8 \%$ & $51.6 \%$ & $73.0 \%$ \\
\hline gardening waste & 49 & - & $15.8 \%$ & $26.5 \%$ & $31.7 \%$ & $41.8 \%$ & $45.5 \%$ & $47.8 \%$ & $50.1 \%$ \\
\hline paper \& cardboard & 113 & - & $30.2 \%$ & $34.4 \%$ & $37.0 \%$ & $40.5 \%$ & $43.3 \%$ & $46.2 \%$ & $53.4 \%$ \\
\hline composites & 42 & - & $18.0 \%$ & $34.0 \%$ & $39.9 \%$ & $45.0 \%$ & $49.0 \%$ & $56.1 \%$ & $72.0 \%$ \\
\hline plastic & 137 & - & $33.3 \%$ & $40.7 \%$ & $60.0 \%$ & $73.0 \%$ & $84.5 \%$ & $86.1 \%$ & $92.1 \%$ \\
\hline combustibles & 152 & - & $18.0 \%$ & $42.6 \%$ & $46.1 \%$ & $50.5 \%$ & $58.6 \%$ & $76.2 \%$ & $87.1 \%$ \\
\hline metal & 14 & - & $0.0 \%$ & $0.0 \%$ & $0.0 \%$ & $0.8 \%$ & $4.5 \%$ & $45.7 \%$ & $76.2 \%$ \\
\hline glass & 14 & - & $0.0 \%$ & $0.0 \%$ & $0.0 \%$ & $0.4 \%$ & $0.5 \%$ & $5.5 \%$ & $9.8 \%$ \\
\hline inert & 14 & - & $0.0 \%$ & $0.0 \%$ & $0.0 \%$ & $1.6 \%$ & $14.6 \%$ & $38.6 \%$ & $47.1 \%$ \\
\hline $\operatorname{mix}$ & 104 & - & $0.6 \%$ & $3.5 \%$ & $23.0 \%$ & $36.8 \%$ & $45.8 \%$ & $52.2 \%$ & $75.2 \%$ \\
\hline
\end{tabular}

Grand Total

911

$\left.{ }^{*}\right)$ number of data points

$\left.{ }^{\star *}\right)$ number of values below the detection limit 


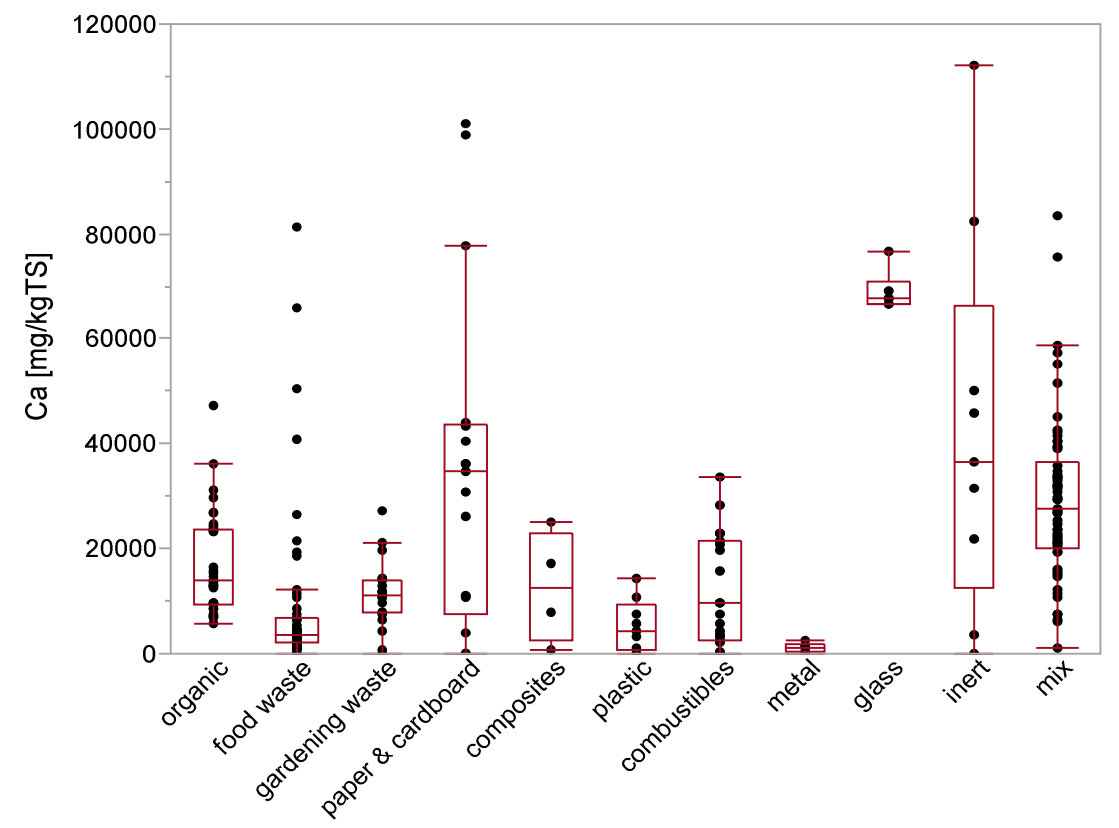

Waste Material Fractions

\section{Quantiles [mg/kgTS]}

\section{Waste Material}

\begin{tabular}{|c|c|c|c|c|c|c|c|c|c|}
\hline Fraction & n_data* & $\mathbf{n} \_<L^{* *}$ & Min & $10 \%$ & $25 \%$ & Median & $75 \%$ & $90 \%$ & Max \\
\hline organic & 38 & - & 5700 & 7180 & 9475 & 14000 & 23750 & 29850 & 47313 \\
\hline food waste & 57 & - & 0 & 1156 & 1977 & 3611 & 6709 & 22553 & 81250 \\
\hline gardening waste & 21 & - & 0 & 1306 & 7750 & 11256 & 14149 & 20838 & 27100 \\
\hline paper \& cardboard & 17 & - & 0 & 0 & 7415 & 34600 & 43600 & 99160 & 101000 \\
\hline composites & 4 & - & 727 & 727 & 2500 & 12555 & 23080 & 25010 & 25010 \\
\hline plastic & 9 & - & 21.5 & 22 & 577 & 4160 & 9270 & 14260 & 14260 \\
\hline combustibles & 23 & - & 45.7 & 51 & 2390 & 9510 & 21522 & 26140 & 33770 \\
\hline metal & 6 & - & 36 & 36 & 192 & 1143 & 1728 & 2410 & 2410 \\
\hline glass & 6 & - & 66730 & 66730 & 66783 & 67775 & 70900 & 76600 & 76600 \\
\hline inert & 9 & - & 0 & 0 & 12675 & 36400 & 66303 & 112110 & 112110 \\
\hline $\operatorname{mix}$ & 62 & - & 1228.6 & 10950 & 20075 & 27500 & 36675 & 49640 & 83550 \\
\hline
\end{tabular}

*) number of data points

$\left.{ }^{* *}\right)$ number of values below the detection limit 
Value ranges for $\mathrm{Cd}$

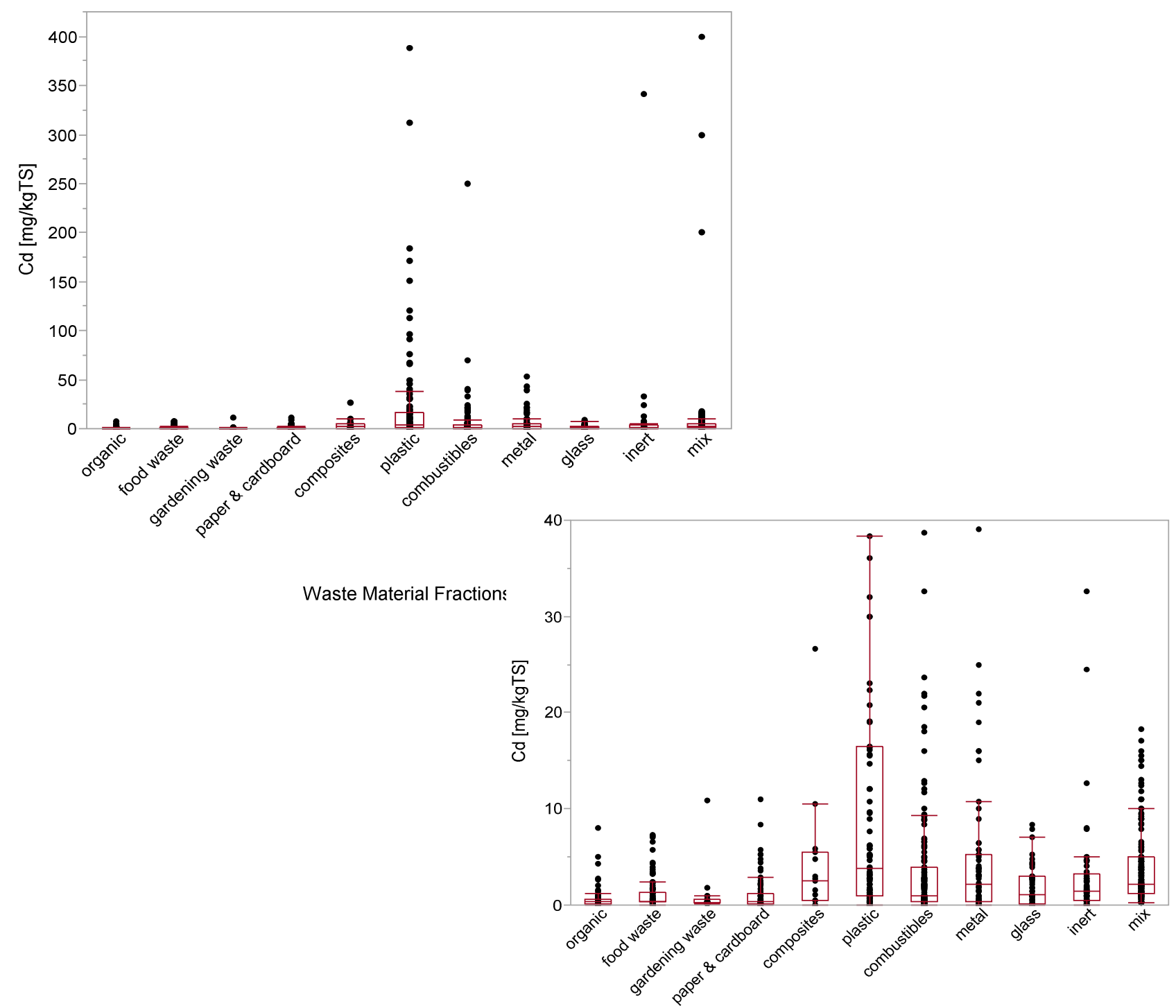

\section{Quantiles [mg/kgTS]}

\begin{tabular}{|c|c|c|c|c|c|c|c|c|c|}
\hline \multirow{2}{*}{$\begin{array}{l}\text { Waste Material } \\
\text { Fraction }\end{array}$} & \multirow[b]{2}{*}{ n_data* } & \multirow[b]{2}{*}{$\mathrm{n}_{-}<\mathrm{DL} * *$} & \multirow[b]{2}{*}{ Min } & \multicolumn{6}{|c|}{ Waste Material Fractions } \\
\hline & & & & $10 \%$ & $25 \%$ & Median & $75 \%$ & $90 \%$ & Max \\
\hline organic & 71 & 5 & 0.00 & 0.08 & 0.15 & 0.35 & 0.60 & 1.56 & 7.95 \\
\hline food waste & 100 & 42 & 0.00 & 0.10 & 0.40 & 0.40 & 1.28 & 3.49 & 7.30 \\
\hline gardening waste & 23 & - & 0.11 & 0.16 & 0.20 & 0.25 & 0.60 & 1.48 & 10.85 \\
\hline paper \& cardboard & 88 & 4 & 0.00 & 0.00 & 0.09 & 0.30 & 1.25 & 3.62 & 11.00 \\
\hline composites & 15 & - & 0.00 & 0.01 & 0.50 & 2.52 & 5.50 & 16.94 & 26.60 \\
\hline plastic & 103 & 2 & 0.00 & 0.20 & 0.90 & 3.80 & 16.50 & 72.68 & 388.00 \\
\hline combustibles & 158 & 3 & 0.00 & 0.00 & 0.30 & 1.00 & 3.93 & 11.73 & 250.00 \\
\hline metal & 71 & 5 & 0.00 & 0.00 & 0.30 & 2.10 & 5.20 & 18.40 & 53.00 \\
\hline glass & 49 & 4 & 0.00 & 0.00 & 0.15 & 1.10 & 2.95 & 4.80 & 8.40 \\
\hline inert & 50 & - & 0.00 & 0.00 & 0.50 & 1.45 & 3.28 & 7.99 & 341.00 \\
\hline $\operatorname{mix}$ & 141 & - & 0.20 & 0.76 & 1.25 & 2.17 & 5.04 & 11.67 & 400.00 \\
\hline Grand Total & 869 & 65 & & & & & & & \\
\hline
\end{tabular}


Value ranges for $\mathrm{Cl}$

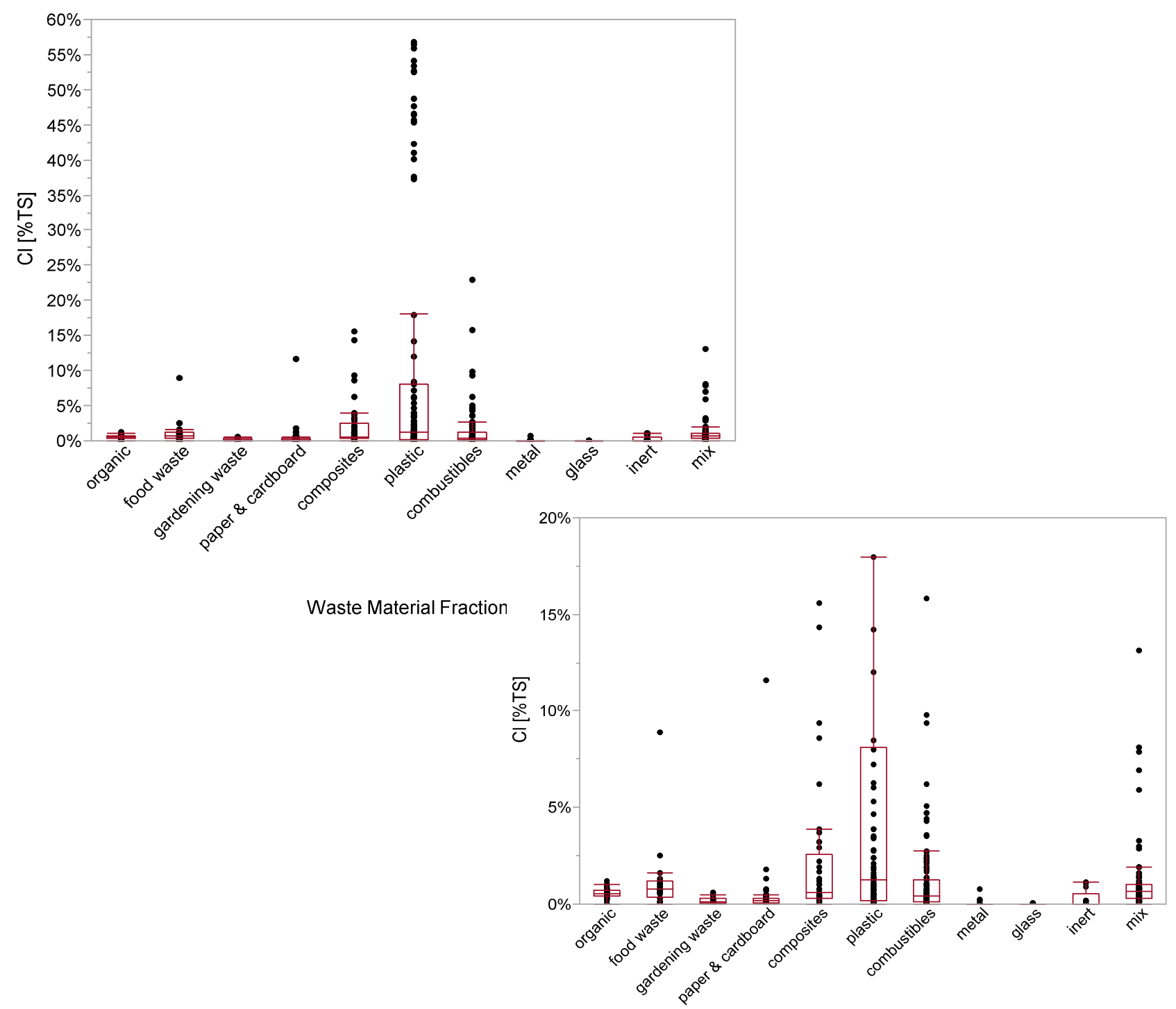

\section{Quantiles [\%TS]}

Waste Material Fractions

\section{Waste Material}

\begin{tabular}{lrrrrrrrrr}
\multicolumn{1}{c}{ Fraction } & n_data* $^{*}$ & $\mathbf{n}_{\mathbf{C}}<\mathbf{D L}^{* *}$ & Min & $\mathbf{1 0 \%}$ & $\mathbf{2 5 \%}$ & Median & $\mathbf{7 5 \%}$ & $\mathbf{9 0 \%}$ & $\mathbf{M a x}$ \\
\hline organic & 58 & - & $0.001 \%$ & $0.165 \%$ & $0.400 \%$ & $0.532 \%$ & $0.700 \%$ & $0.806 \%$ & $1.200 \%$ \\
food waste & 20 & - & $0.000 \%$ & $0.012 \%$ & $0.365 \%$ & $0.765 \%$ & $1.173 \%$ & $2.413 \%$ & $8.900 \%$ \\
gardening waste & 26 & - & $0.000 \%$ & $0.047 \%$ & $0.078 \%$ & $0.110 \%$ & $0.283 \%$ & $0.530 \%$ & $0.600 \%$ \\
paper \& cardboard & 75 & - & $0.000 \%$ & $0.001 \%$ & $0.070 \%$ & $0.160 \%$ & $0.300 \%$ & $0.500 \%$ & $11.600 \%$ \\
composites & 41 & - & $0.000 \%$ & $0.000 \%$ & $0.300 \%$ & $0.600 \%$ & $2.550 \%$ & $8.120 \%$ & $15.600 \%$ \\
plastic & 90 & - & $0.000 \%$ & $0.000 \%$ & $0.200 \%$ & $1.250 \%$ & $8.125 \%$ & $47.605 \%$ & $56.800 \%$ \\
combustibles & 114 & - & $0.000 \%$ & $0.000 \%$ & $0.100 \%$ & $0.400 \%$ & $1.248 \%$ & $3.550 \%$ & $23.000 \%$ \\
metal & 19 & - & $0.000 \%$ & $0.000 \%$ & $0.000 \%$ & $0.000 \%$ & $0.001 \%$ & $0.240 \%$ & $0.760 \%$ \\
glass & 10 & - & $0.000 \%$ & $0.000 \%$ & $0.000 \%$ & $0.000 \%$ & $0.000 \%$ & $0.054 \%$ & $0.060 \%$ \\
inert & 13 & - & $0.000 \%$ & $0.000 \%$ & $0.000 \%$ & $0.020 \%$ & $0.550 \%$ & $1.094 \%$ & $1.110 \%$ \\
mix & 81 & - & $0.000 \%$ & $0.104 \%$ & $0.305 \%$ & $0.670 \%$ & $1.000 \%$ & $2.692 \%$ & $13.160 \%$ \\
\hline Total & 547 & 0 & & & & & & &
\end{tabular}

*) number of data points

$\left.{ }^{\star *}\right)$ number of values below the detection limit 
Value ranges for Co

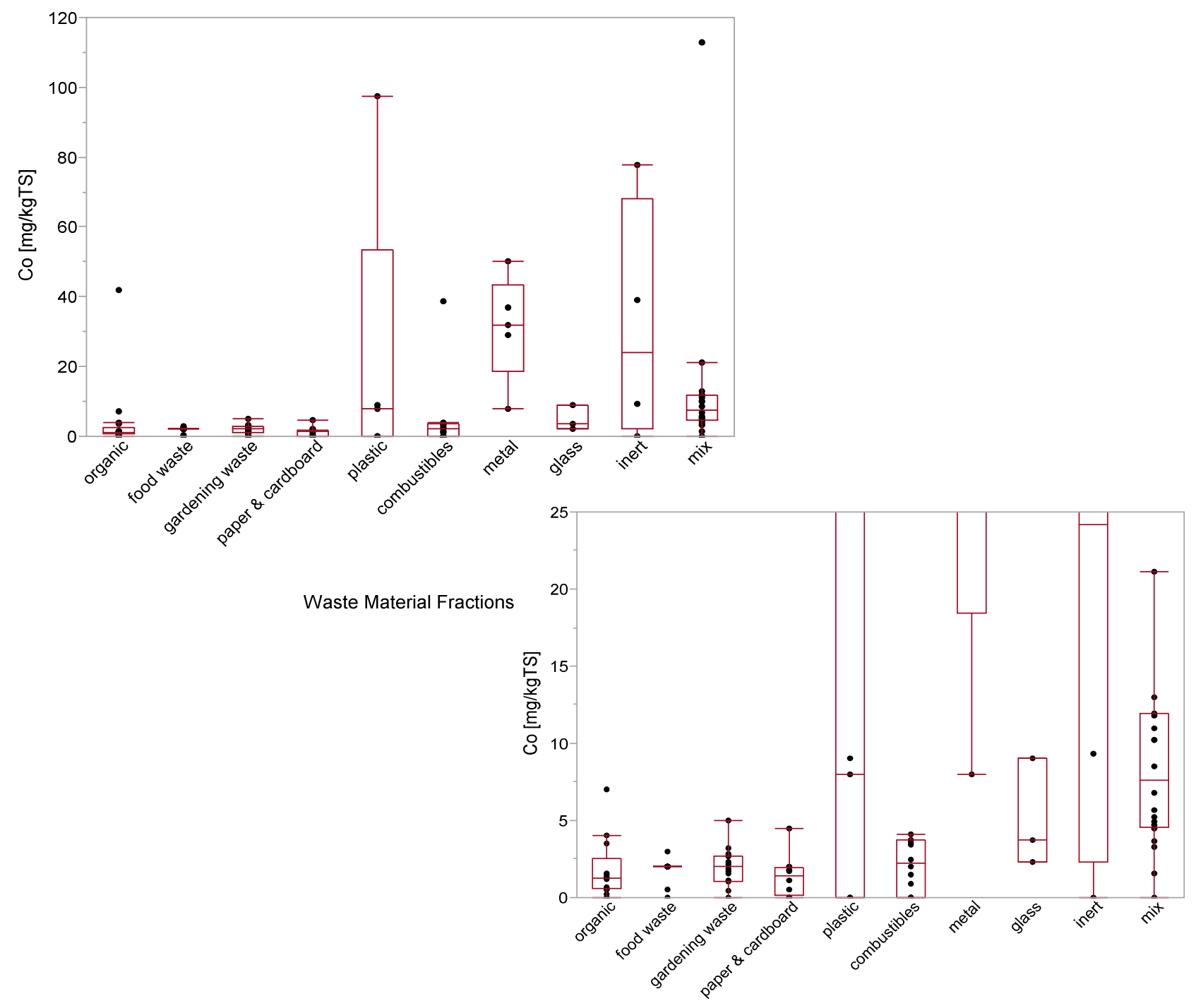

Quantiles [mg/kgTS]

Waste Material Fractions

\begin{tabular}{|c|c|c|c|c|c|c|c|c|c|}
\hline $\begin{array}{l}\text { Waste Material } \\
\text { Fraction }\end{array}$ & n_data* & $n \_<L^{* *}$ & Min & $10 \%$ & $25 \%$ & Median & $75 \%$ & $90 \%$ & Max \\
\hline organic & 17 & 1 & 0.0 & 0.2 & 0.6 & 1.3 & 2.6 & 14.0 & 42.0 \\
\hline food waste & 43 & 41 & 0.0 & 2.0 & 2.0 & 2.0 & 2.0 & 2.0 & 3.0 \\
\hline gardening waste & 14 & - & 0.0 & 0.2 & 1.1 & 2.0 & 2.7 & 4.1 & 5.0 \\
\hline paper \& cardboard & 8 & 1 & 0.0 & 0.0 & 0.1 & 1.4 & 2.0 & 4.5 & 4.5 \\
\hline composites & - & - & - & - & - & - & - & - & - \\
\hline plastic & 5 & - & 0.0 & 0.0 & 0.0 & 8.0 & 53.3 & 97.6 & 97.6 \\
\hline combustibles & 14 & - & 0.0 & 0.0 & 0.0 & 2.3 & 3.7 & 21.4 & 38.7 \\
\hline metal & 5 & - & 8.0 & 8.0 & 18.5 & 32.0 & 43.5 & 50.0 & 50.0 \\
\hline glass & 3 & - & 2.3 & 2.3 & 2.3 & 3.7 & 9.0 & 9.0 & 9.0 \\
\hline inert & 4 & - & 0.0 & 0.0 & 2.3 & 24.2 & 68.0 & 77.7 & 77.7 \\
\hline $\operatorname{mix}$ & 20 & - & 0.0 & 1.8 & 4.5 & 7.6 & 11.9 & 103.8 & 113.0 \\
\hline
\end{tabular}

*) number of data points

${ }^{* *}$ ) number of values below the detection limit 


\section{Value ranges for $\mathrm{Cr}$}

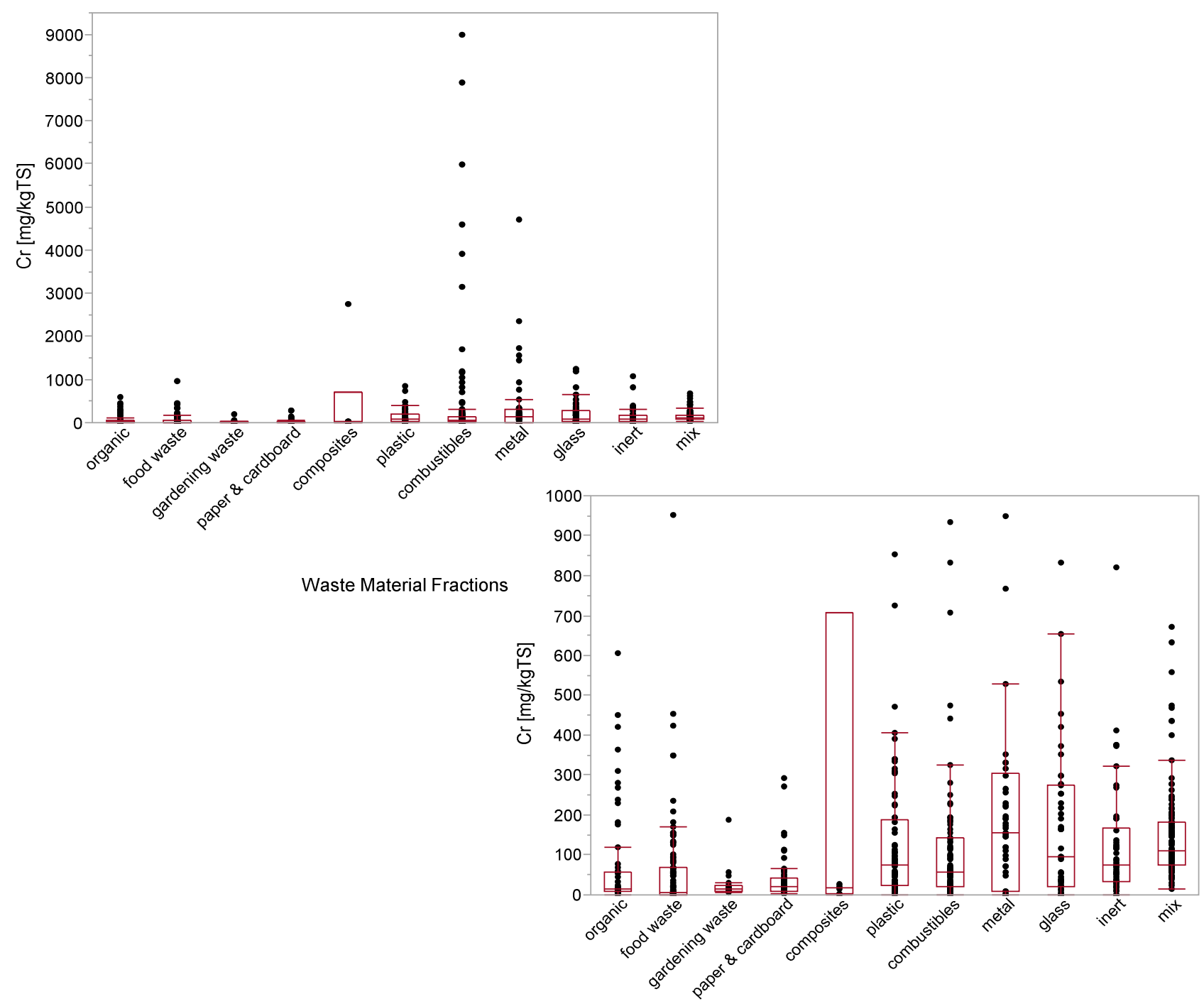

\section{Quantiles [mg/kgTS]}

Waste Material Fractions

\begin{tabular}{|c|c|c|c|c|c|c|c|c|c|}
\hline $\begin{array}{c}\text { Waste Material } \\
\text { Fraction }\end{array}$ & n_data* & $n_{-}<D L^{* *}$ & Min & $10 \%$ & $25 \%$ & Median & $75 \%$ & $90 \%$ & Max \\
\hline organic & 62 & - & 1.3 & 6.2 & 8.4 & 14.8 & 56.3 & 277.0 & 607.0 \\
\hline food waste & 103 & 17 & 0.0 & 1.0 & 1.1 & 5.2 & 69.0 & 155.3 & 951.5 \\
\hline gardening waste & 19 & 1 & 4.5 & 8.0 & 8.7 & 16.2 & 23.0 & 55.5 & 188.7 \\
\hline paper \& cardboard & 65 & - & 2.5 & 5.4 & 8.8 & 20.0 & 40.3 & 99.4 & 291.8 \\
\hline composites & 6 & - & 1.0 & 1.0 & 2.4 & 18.5 & 708.5 & 2750.0 & 2750.0 \\
\hline plastic & 73 & - & 0.4 & 9.7 & 25.4 & 73.9 & 187.0 & 338.4 & 853.0 \\
\hline combustibles & 122 & - & 0.0 & 6.2 & 19.8 & 56.4 & 142.2 & 795.3 & 9000.0 \\
\hline metal & 50 & - & 0.0 & 0.0 & 9.2 & 154.5 & 304.3 & 1387.0 & 4702.0 \\
\hline glass & 49 & - & 0.0 & 0.0 & 21.6 & 95.3 & 275.7 & 534.0 & 1236.8 \\
\hline inert & 50 & - & 0.0 & 13.4 & 34.0 & 74.3 & 167.5 & 377.1 & 1075.5 \\
\hline $\operatorname{mix}$ & 116 & - & 16.0 & 53.0 & 74.8 & 111.8 & 182.3 & 277.1 & 671.1 \\
\hline
\end{tabular}

\begin{tabular}{lll}
\hline Grand Total & 715 & 18
\end{tabular}

*) number of data points

${ }^{* *}$ ) number of values below the detection limit 


\section{Value ranges for $\mathrm{Cu}$}

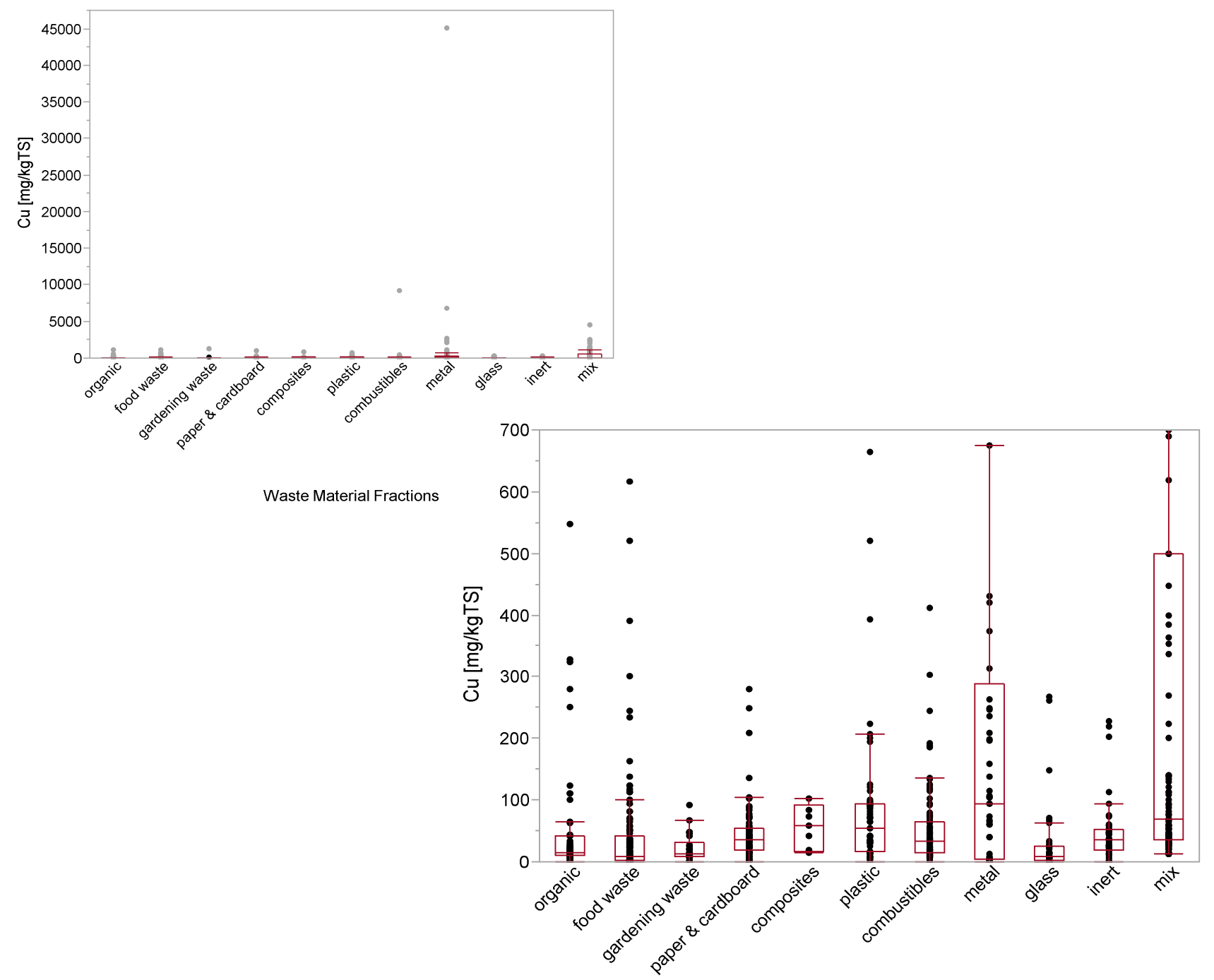

\section{Quantiles [mg/kgTS]}

Waste Material Fractions

\begin{tabular}{|c|c|c|c|c|c|c|c|c|c|}
\hline $\begin{array}{l}\text { Waste Material } \\
\text { Fraction }\end{array}$ & n_data* & $\mathrm{n}_{-}<\mathrm{DL} * *$ & Min & $10 \%$ & $25 \%$ & Median & $75 \%$ & $90 \%$ & Max \\
\hline organic & 59 & - & 0.00 & 7.22 & 10.20 & 15.10 & 41.45 & 250.00 & 1196.59 \\
\hline food waste & 117 & 40 & 0.00 & 2.00 & 2.00 & 9.00 & 42.00 & 126.82 & 1168.20 \\
\hline gardening waste & 30 & - & 0.18 & 0.60 & 7.93 & 13.11 & 31.25 & 64.30 & 1238.61 \\
\hline paper \& cardboard & 72 & - & 0.00 & 7.86 & 17.78 & 34.76 & 55.20 & 98.49 & 1019.60 \\
\hline composites & 9 & - & 14.00 & 14.00 & 17.05 & 59.40 & 92.55 & 834.00 & 834.00 \\
\hline plastic & 57 & - & 0.00 & 8.24 & 16.85 & 54.20 & 93.85 & 201.20 & 665.30 \\
\hline combustibles & 112 & - & 0.00 & 8.79 & 14.35 & 33.60 & 65.35 & 131.93 & 9240.00 \\
\hline metal & 53 & 1 & 0.00 & 0.00 & 4.55 & 94.50 & 288.60 & 1691.20 & 45100.00 \\
\hline glass & 42 & - & 0.00 & 0.00 & 1.85 & 8.50 & 26.00 & 69.64 & 267.50 \\
\hline inert & 46 & - & 0.00 & 0.56 & 18.58 & 35.80 & 51.70 & 99.70 & 227.00 \\
\hline $\operatorname{mix}$ & 110 & - & 12.17 & 19.61 & 35.21 & 67.93 & 500.00 & 1154.99 & 4500.00 \\
\hline Grand Total & 707 & 41 & & & & & & & \\
\hline
\end{tabular}

*) number of data points

${ }^{* *}$ ) number of values below the detection limit 
Value ranges for $F$

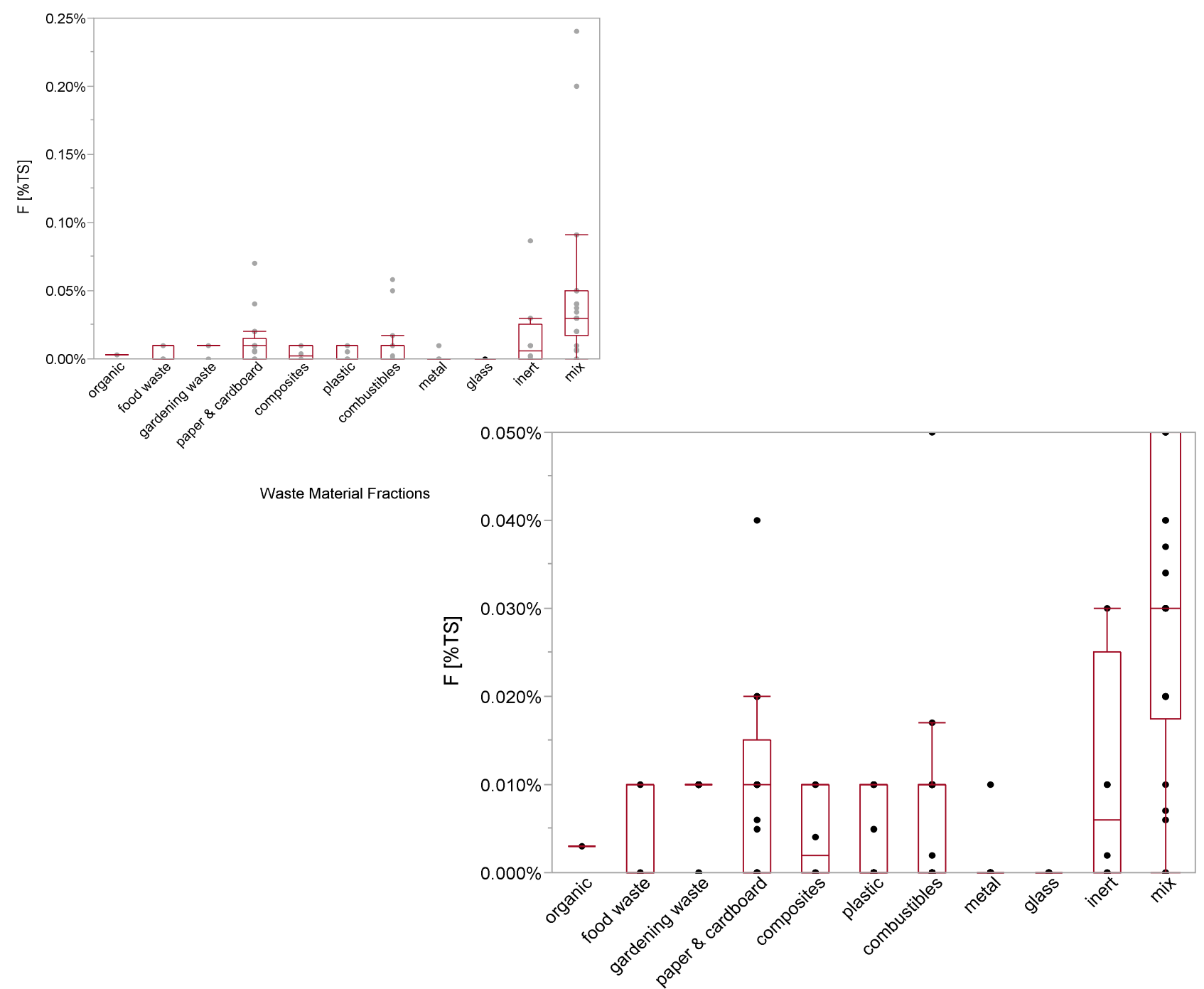

Quantiles [\%TS]

Waste Material Fractions

Waste Material

\begin{tabular}{lrrrrrrrrr}
\multicolumn{1}{c}{ Fraction } & $\mathbf{n}$ data*$^{*}$ & $\mathbf{n}<$ DL** $^{*}$ & Min & $\mathbf{1 0 \%}$ & $\mathbf{2 5 \%}$ & Median & $\mathbf{7 5 \%}$ & $\mathbf{9 0 \%}$ & $\mathbf{M a x}$ \\
\hline organic & - & - & - & - & - & - & - & - & - \\
food waste & 5 & - & $0.000 \%$ & $0.000 \%$ & $0.000 \%$ & $0.000 \%$ & $0.010 \%$ & $0.010 \%$ & $0.010 \%$ \\
gardening waste & 16 & 12 & $0.000 \%$ & $0.000 \%$ & $0.010 \%$ & $0.010 \%$ & $0.010 \%$ & $0.010 \%$ & $0.010 \%$ \\
paper \& cardboard & 21 & - & $0.000 \%$ & $0.000 \%$ & $0.000 \%$ & $0.010 \%$ & $0.015 \%$ & $0.036 \%$ & $0.070 \%$ \\
composites & 6 & - & $0.000 \%$ & $0.000 \%$ & $0.000 \%$ & $0.002 \%$ & $0.010 \%$ & $0.010 \%$ & $0.010 \%$ \\
plastic & 14 & - & $0.000 \%$ & $0.000 \%$ & $0.000 \%$ & $0.000 \%$ & $0.010 \%$ & $0.010 \%$ & $0.010 \%$ \\
combustibles & 25 & - & $0.000 \%$ & $0.000 \%$ & $0.000 \%$ & $0.010 \%$ & $0.010 \%$ & $0.030 \%$ & $0.058 \%$ \\
metal & 17 & - & $0.000 \%$ & $0.000 \%$ & $0.000 \%$ & $0.000 \%$ & $0.000 \%$ & $0.002 \%$ & $0.010 \%$ \\
glass & 6 & - & $0.000 \%$ & $0.000 \%$ & $0.000 \%$ & $0.000 \%$ & $0.000 \%$ & $0.000 \%$ & $0.000 \%$ \\
inert & 8 & - & $0.000 \%$ & $0.000 \%$ & $0.000 \%$ & $0.006 \%$ & $0.025 \%$ & $0.087 \%$ & $0.087 \%$ \\
mix & 22 & - & $0.000 \%$ & $0.002 \%$ & $0.018 \%$ & $0.030 \%$ & $0.050 \%$ & $0.200 \%$ & $0.240 \%$ \\
\hline Total & 140 & 12 & & & & & & &
\end{tabular}

$\left.{ }^{*}\right)$ number of data points

$\left.{ }^{\star *}\right)$ number of values below the detection limit 


\section{Value ranges for $\mathrm{Fe}$}

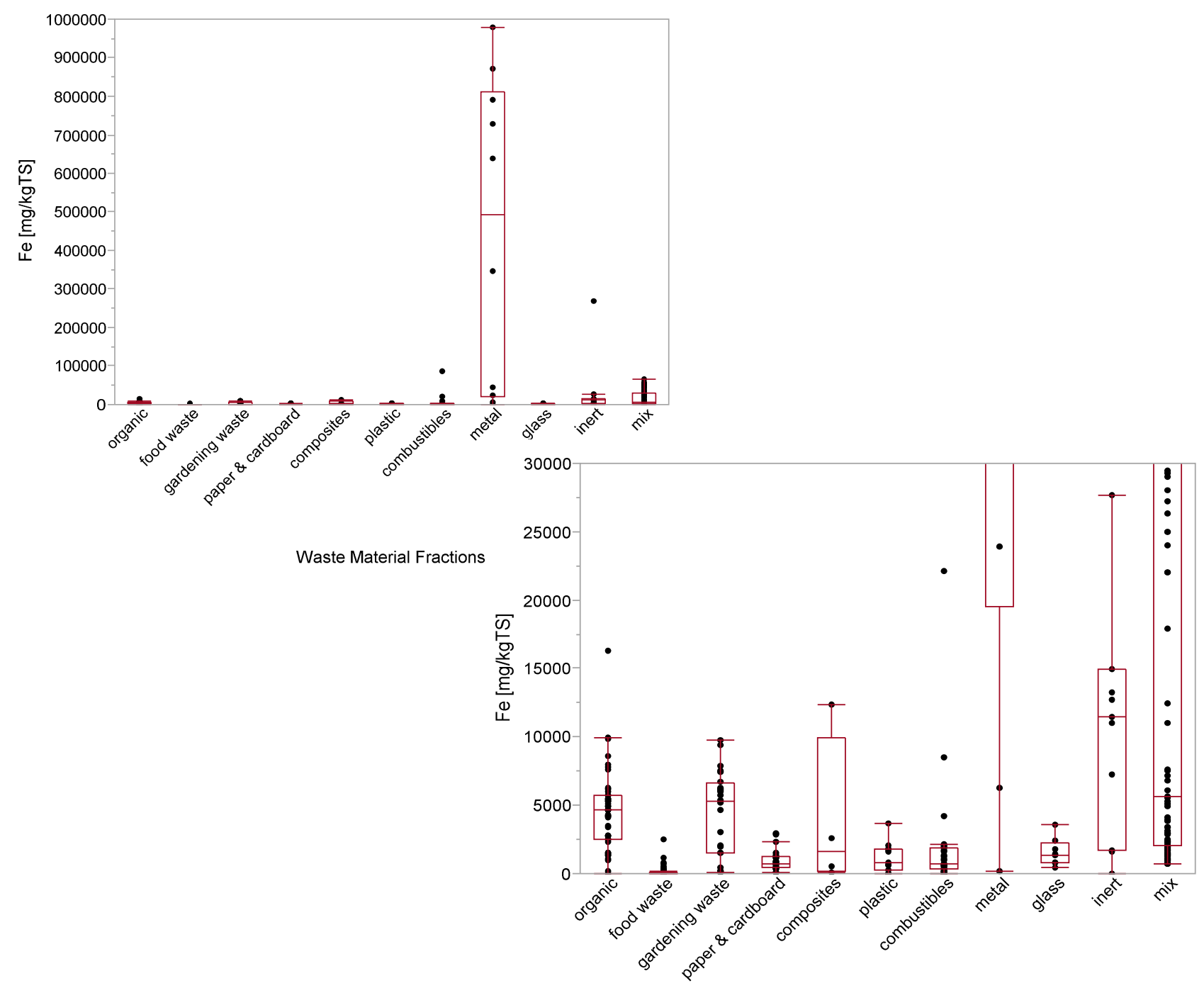

\section{Quantiles [mg/kgTS]}

Waste Material Fractions

\begin{tabular}{|c|c|c|c|c|c|c|c|c|c|}
\hline $\begin{array}{l}\text { Waste Material } \\
\text { Fraction }\end{array}$ & n_data* & $n \_<L^{* *}$ & Min & $10 \%$ & $25 \%$ & Median & $75 \%$ & $90 \%$ & Max \\
\hline organic & 45 & - & 0 & 1220 & 2500 & 4700 & 5700 & 8240 & 16333 \\
\hline food waste & 64 & - & 0 & 18 & 29 & 48 & 88 & 409 & 2478 \\
\hline gardening waste & 24 & - & 76 & 168 & 1485 & 5270 & 6600 & 8643 & 9728 \\
\hline paper \& cardboard & 22 & - & 46 & 147 & 459 & 755 & 1245 & 2722 & 2940 \\
\hline composites & 4 & - & 86 & 86 & 199 & 1585 & 9898 & 12320 & 12320 \\
\hline plastic & 11 & - & 0 & 0 & 305 & 849 & 1830 & 3380 & 3700 \\
\hline combustibles & 31 & - & 0 & 9 & 340 & 733 & 1850 & 7634 & 85100 \\
\hline metal & 10 & - & 150 & 765 & 19500 & 492500 & 810750 & 969300 & 980000 \\
\hline glass & 8 & - & 477 & 477 & 777 & 1350 & 2240 & 3567 & 3567 \\
\hline inert & 11 & - & 0 & 320 & 1730 & 11500 & 14990 & 219940 & 268000 \\
\hline $\operatorname{mix}$ & 82 & - & 684 & 1299 & 2017 & 5605 & 30819 & 49137 & 66000 \\
\hline
\end{tabular}

*) number of data points

${ }^{\star *}$ ) number of values below the detection limit 


\section{Value ranges for $\mathrm{H}$}

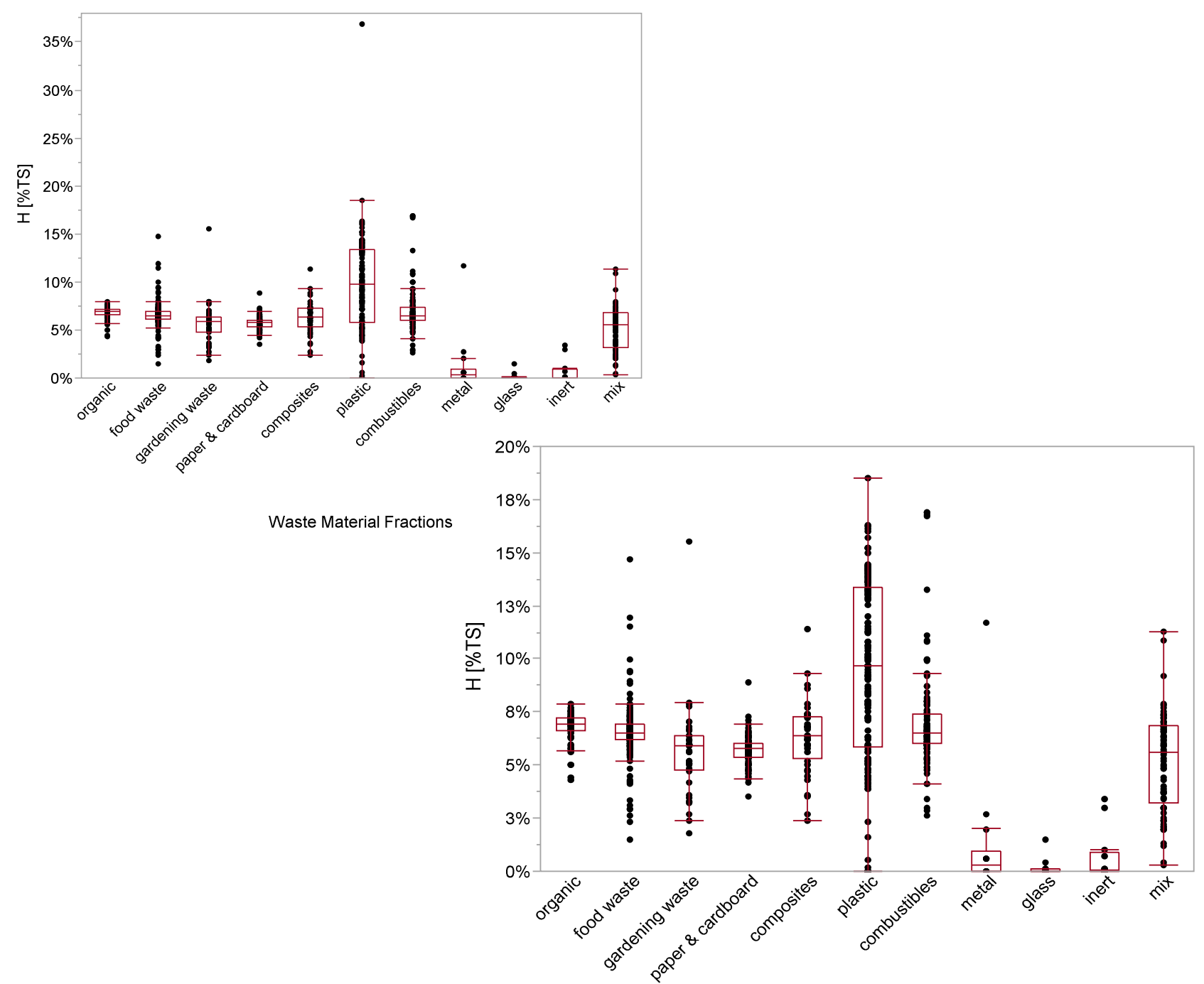

Quantiles [\%TS]

Waste Material Fractions

Waste Material

\begin{tabular}{lrrrrrrrrr}
\multicolumn{1}{c}{ Fraction } & $\mathbf{n} \mathbf{d a t a}^{*}$ & $\mathbf{n}<\mathbf{D L}^{* *}$ & \multicolumn{1}{c}{ Min } & $\mathbf{1 0} \%$ & $\mathbf{2 5 \%}$ & Median & $\mathbf{7 5 \%}$ & \multicolumn{9}{c}{$\mathbf{9 0 \%}$} & \multicolumn{1}{c}{ Max } \\
\hline organic & 59 & - & $4.3 \%$ & $5.7 \%$ & $6.6 \%$ & $6.9 \%$ & $7.2 \%$ & $7.5 \%$ & $7.9 \%$ \\
food waste & 173 & - & $1.5 \%$ & $5.5 \%$ & $6.2 \%$ & $6.5 \%$ & $6.9 \%$ & $7.6 \%$ & $14.7 \%$ \\
gardening waste & 40 & - & $1.8 \%$ & $3.2 \%$ & $4.8 \%$ & $5.9 \%$ & $6.4 \%$ & $7.7 \%$ & $15.5 \%$ \\
paper \& cardboard & 112 & - & $3.5 \%$ & $4.8 \%$ & $5.4 \%$ & $5.8 \%$ & $6.0 \%$ & $6.4 \%$ & $8.9 \%$ \\
composites & 40 & - & $2.4 \%$ & $3.7 \%$ & $5.3 \%$ & $6.4 \%$ & $7.3 \%$ & $8.5 \%$ & $11.4 \%$ \\
plastic & 151 & - & $0.0 \%$ & $3.9 \%$ & $5.8 \%$ & $9.7 \%$ & $13.4 \%$ & $14.4 \%$ & $36.9 \%$ \\
combustibles & 138 & - & $2.6 \%$ & $5.3 \%$ & $6.0 \%$ & $6.5 \%$ & $7.4 \%$ & $9.3 \%$ & $16.9 \%$ \\
metal & 14 & - & $0.0 \%$ & $0.0 \%$ & $0.0 \%$ & $0.3 \%$ & $1.0 \%$ & $7.2 \%$ & $11.7 \%$ \\
glass & 13 & 1 & $0.0 \%$ & $0.0 \%$ & $0.0 \%$ & $0.0 \%$ & $0.1 \%$ & $1.1 \%$ & $1.5 \%$ \\
inert & 12 & - & $0.0 \%$ & $0.0 \%$ & $0.0 \%$ & $0.1 \%$ & $0.9 \%$ & $3.3 \%$ & $3.4 \%$ \\
mix & 73 & - & $0.3 \%$ & $2.0 \%$ & $3.2 \%$ & $5.6 \%$ & $6.8 \%$ & $7.5 \%$ & $11.3 \%$ \\
\hline Grand Total & 825 & 1 & & & & & & &
\end{tabular}

*) number of data points

${ }^{* *}$ ) number of values below the detection limit 
Value ranges for $\mathrm{Hg}$

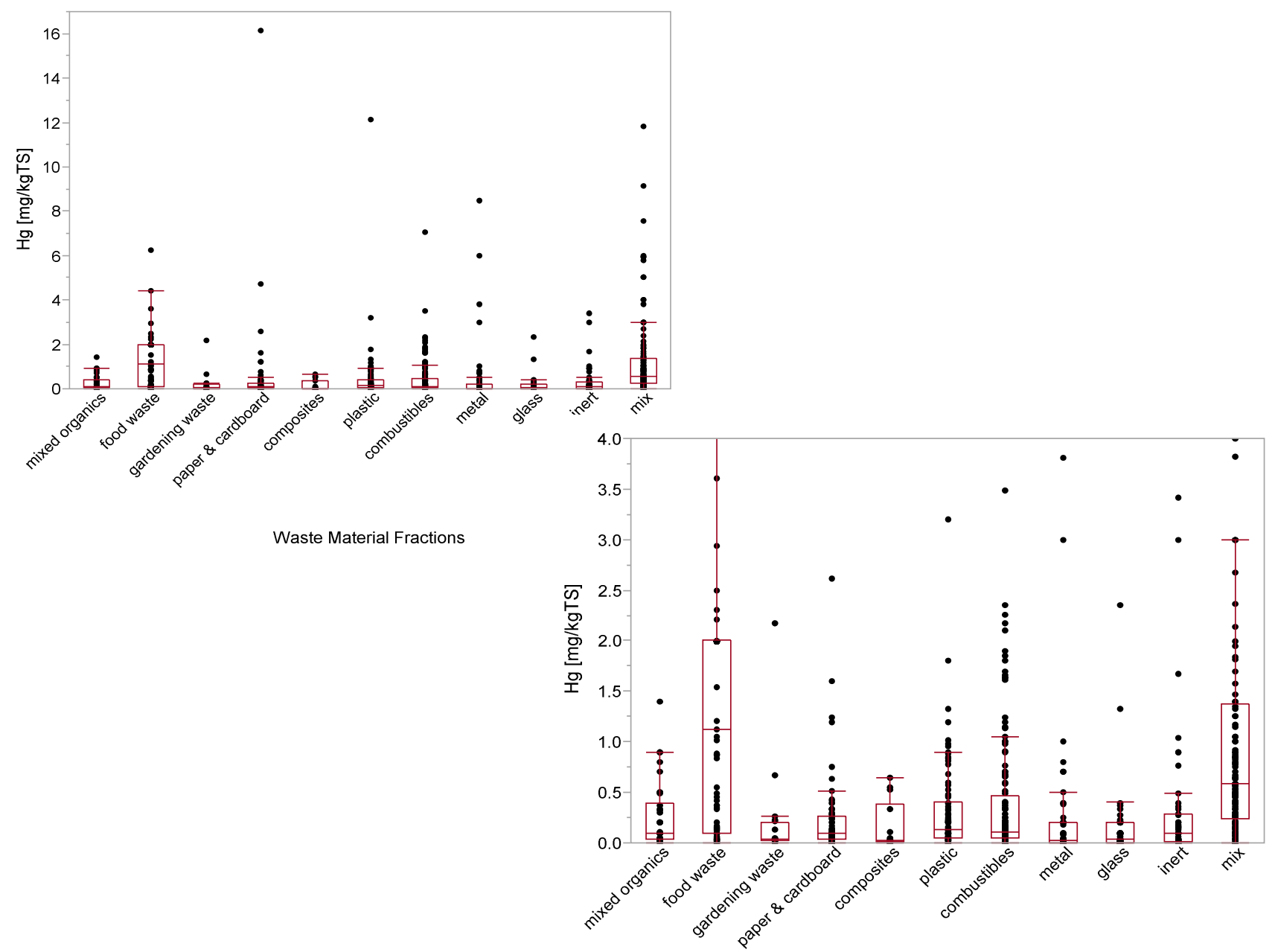

Quantiles [mg/kgTS]

\begin{tabular}{|c|c|c|c|c|c|c|c|c|c|}
\hline \multirow{2}{*}{$\begin{array}{l}\text { Waste Material } \\
\text { Fraction }\end{array}$} & \multirow[b]{2}{*}{ n_data* } & \multirow[b]{2}{*}{$\mathrm{n}_{-}<\mathrm{DL} \mathbf{L}^{\star *}$} & \multirow[b]{2}{*}{ Min } & \multirow[b]{2}{*}{$10 \%$} & \multicolumn{4}{|c|}{ Waste Material Fractions } & \multirow[b]{2}{*}{$\operatorname{Max}$} \\
\hline & & & & & $25 \%$ & Median & $75 \%$ & $90 \%$ & \\
\hline organic & 34 & 4 & 0.000 & 0.020 & 0.040 & 0.100 & 0.396 & 0.850 & 1.400 \\
\hline food waste & 99 & 41 & 0.000 & 0.020 & 0.100 & 1.120 & 2.000 & 2.000 & 6.250 \\
\hline food waste -alt ${ }^{\star \star \star}$ & 59 & 1 & 0.000 & 0.000 & 0.040 & 0.140 & 0.870 & 2.310 & 6.250 \\
\hline gardening waste & 20 & 3 & 0.000 & 0.020 & 0.023 & 0.040 & 0.198 & 0.629 & 2.170 \\
\hline paper \& cardboard & 84 & 6 & 0.000 & 0.000 & 0.030 & 0.098 & 0.265 & 0.570 & 16.160 \\
\hline composites & 14 & - & 0.000 & 0.000 & 0.008 & 0.025 & 0.380 & 0.595 & 0.640 \\
\hline plastic & 89 & 3 & 0.000 & 0.000 & 0.045 & 0.130 & 0.400 & 0.891 & 12.150 \\
\hline combustibles & 140 & 6 & 0.000 & 0.000 & 0.050 & 0.110 & 0.470 & 1.573 & 7.030 \\
\hline metal & 60 & 5 & 0.000 & 0.000 & 0.000 & 0.025 & 0.200 & 0.790 & 8.500 \\
\hline glass & 49 & 6 & 0.000 & 0.000 & 0.000 & 0.040 & 0.200 & 0.340 & 2.350 \\
\hline inert & 49 & 5 & 0.000 & 0.000 & 0.015 & 0.100 & 0.285 & 0.900 & 3.420 \\
\hline $\operatorname{mix}$ & 113 & - & 0.000 & 0.070 & 0.235 & 0.580 & 1.375 & 3.928 & 11.800 \\
\hline
\end{tabular}

Grand Total

$\left.{ }^{*}\right)$ number of data points

${ }^{* *}$ ) number of values below the detection limit

${ }^{* \star *}$ ) alternativ calculation excluding 55 data points from Wrap 2010, which were all below the same detection limit 


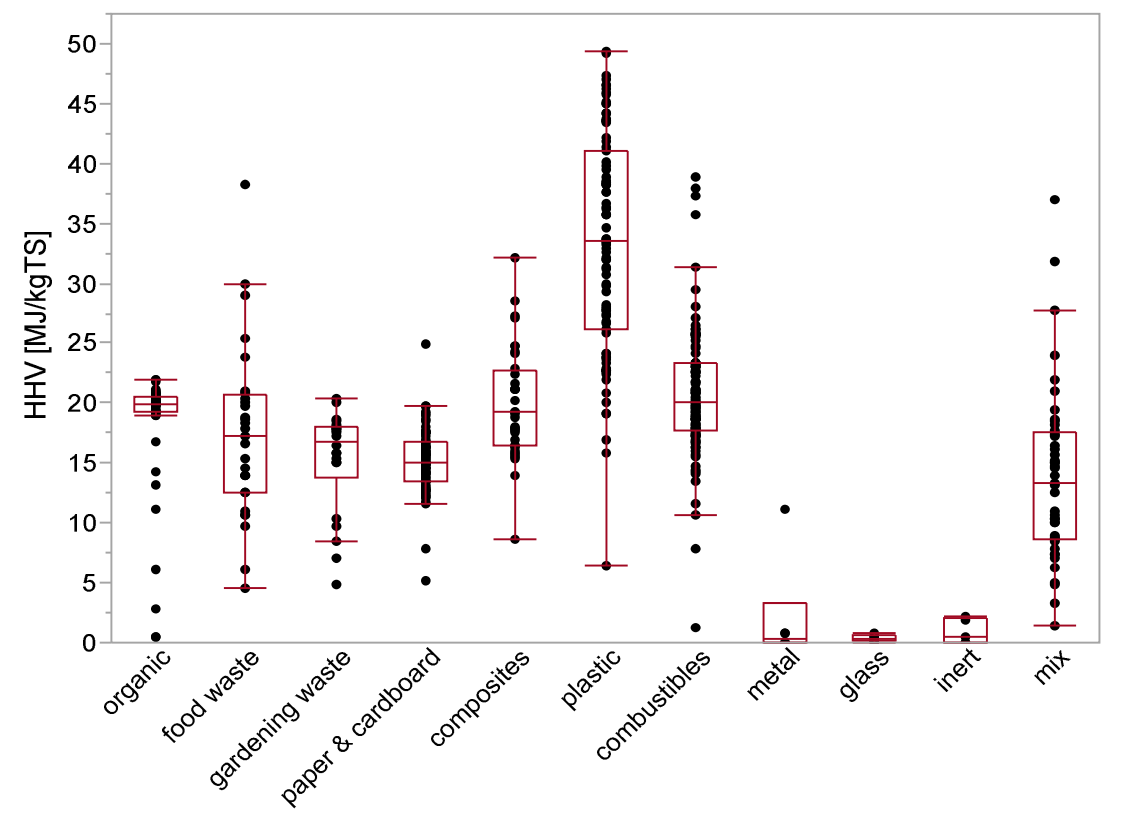

Waste Material Fractions

\section{Quantiles [MJ/kgTS]}

\begin{tabular}{|c|c|c|c|c|c|c|c|c|c|}
\hline $\begin{array}{c}\text { Waste Material } \\
\text { Fraction }\end{array}$ & n_data* & $\mathrm{n}_{-}<\mathrm{DL}$ ** & Min & $10 \%$ & $25 \%$ & Median & $75 \%$ & $90 \%$ & Max \\
\hline organic & 55 & 2 & 0.5 & 12.4 & 19.2 & 20.0 & 20.6 & 21.0 & 22.0 \\
\hline food waste & 29 & - & 4.6 & 9.6 & 12.5 & 17.3 & 20.6 & 29.0 & 38.3 \\
\hline gardening waste & 22 & - & 4.8 & 7.4 & 13.9 & 16.8 & 18.0 & 19.6 & 20.4 \\
\hline paper \& cardboard & 79 & - & 5.2 & 12.4 & 13.6 & 15.1 & 16.7 & 18.5 & 24.9 \\
\hline composites & 36 & - & 8.6 & 15.4 & 16.4 & 19.2 & 22.8 & 27.2 & 32.2 \\
\hline plastic & 91 & - & 6.5 & 22.4 & 26.1 & 33.5 & 41.0 & 45.7 & 49.4 \\
\hline combustibles & 100 & - & 1.3 & 15.5 & 17.7 & 20.0 & 23.3 & 26.2 & 38.9 \\
\hline metal & 6 & - & 0.0 & 0.0 & 0.0 & 0.4 & 3.3 & 11.1 & 11.1 \\
\hline glass & 6 & 2 & 0.0 & 0.0 & 0.1 & 0.4 & 0.6 & 0.8 & 0.8 \\
\hline inert & 5 & 1 & 0.0 & 0.0 & 0.0 & 0.5 & 2.0 & 2.2 & 2.2 \\
\hline $\operatorname{mix}$ & 45 & - & 1.4 & 5.8 & 8.6 & 13.4 & 17.5 & 22.8 & 37.0 \\
\hline
\end{tabular}

*) number of data points

${ }^{* *}$ ) number of values below the detection limit 


\section{Value ranges for $K$}

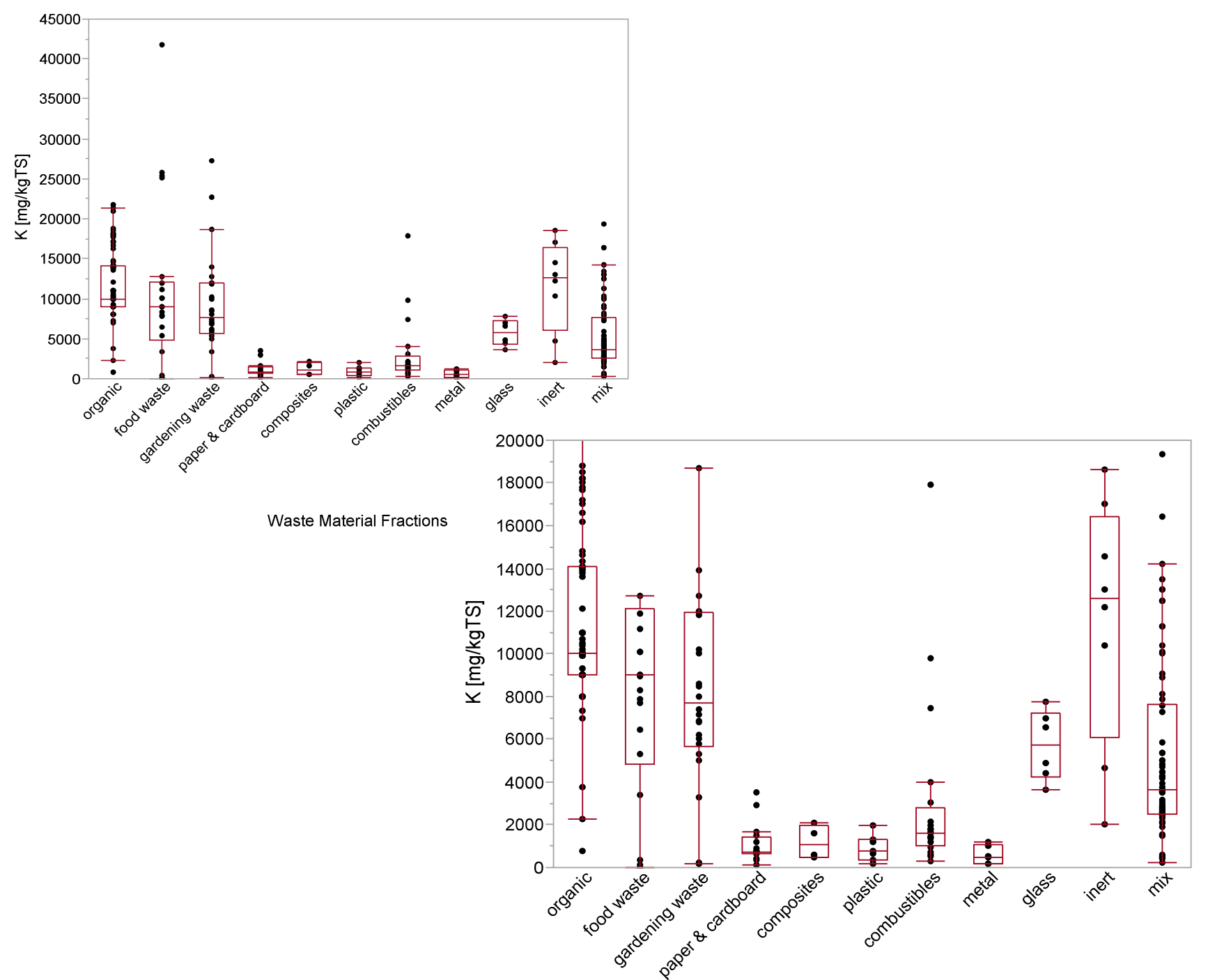

\section{Quantiles [mg/kgTS]}

Waste Material Fractions

\begin{tabular}{|c|c|c|c|c|c|c|c|c|c|}
\hline $\begin{array}{l}\text { Waste Material } \\
\text { Fraction }\end{array}$ & n_data* & $\mathrm{n}_{-}<\mathrm{DL}$ ** & Min & $10 \%$ & $25 \%$ & Median & $75 \%$ & $90 \%$ & Max \\
\hline organic & 76 & - & 795 & 8000 & 9000 & 10000 & 14075 & 18060 & 21700 \\
\hline food waste & 22 & - & 0 & 34 & 4850 & 8989 & 12100 & 25693 & 41800 \\
\hline gardening waste & 26 & - & 161 & 216 & 5677 & 7695 & 11960 & 19900 & 27300 \\
\hline paper \& cardboard & 16 & - & 118 & 297 & 676 & 743 & 1430 & 3080 & 3500 \\
\hline composites & 4 & - & 472 & 472 & 497 & 1096 & 1980 & 2100 & 2100 \\
\hline plastic & 7 & - & 190 & 190 & 372 & 750 & 1300 & 1990 & 1990 \\
\hline combustibles & 20 & - & 278 & 564 & 1016 & 1640 & 2803 & 9565 & 17900 \\
\hline metal & 6 & - & 162 & 162 & 191 & 501 & 1045 & 1190 & 1190 \\
\hline glass & 6 & - & 3650 & 3650 & 4237 & 5730 & 7195 & 7750 & 7750 \\
\hline inert & 8 & - & 2010 & 2010 & 6110 & 12600 & 16408 & 18600 & 18600 \\
\hline $\operatorname{mix}$ & 70 & - & 249 & 1484 & 2500 & 3622 & 7638 & 12497 & 19339 \\
\hline
\end{tabular}

*) number of data points

${ }^{* *}$ ) number of values below the detection limit 


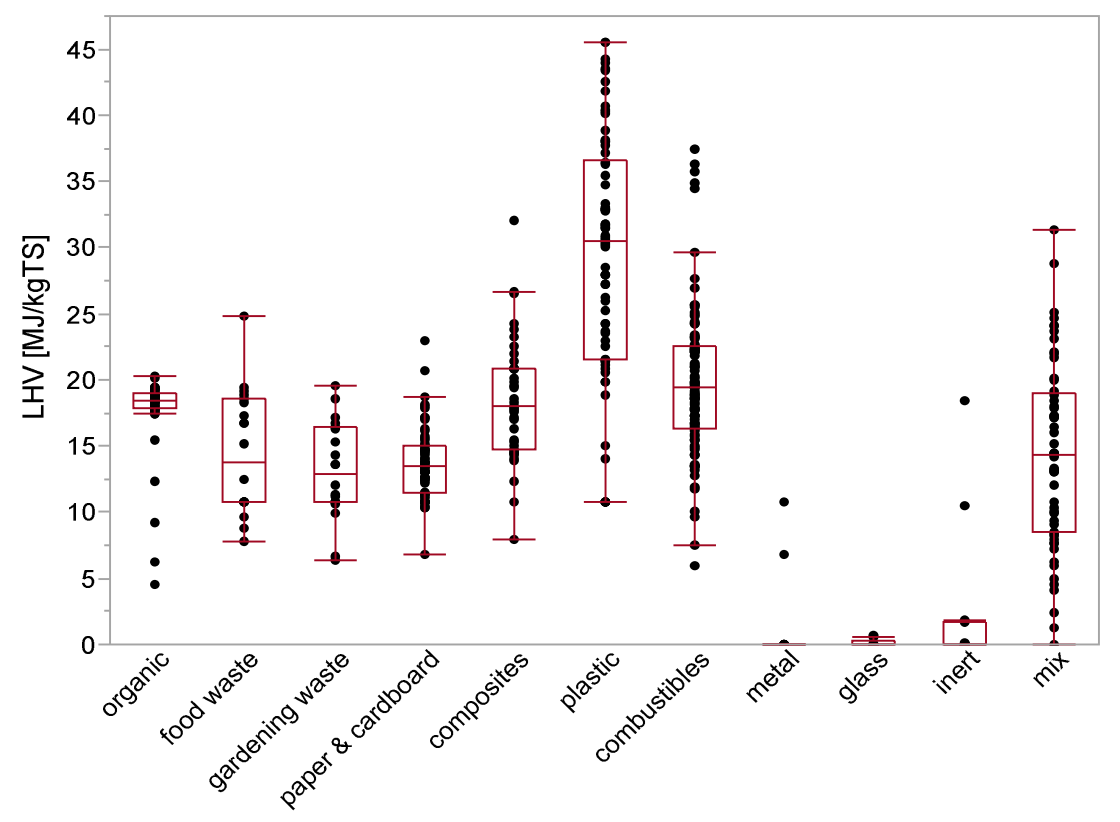

Waste Material Fractions

\section{Quantiles [MJ/kgTS]}

\begin{tabular}{|c|c|c|c|c|c|c|c|c|c|}
\hline $\begin{array}{l}\text { Waste Material } \\
\text { Fraction }\end{array}$ & n_data* & $\mathrm{n} \_<L^{* *}$ & Min & $10 \%$ & $25 \%$ & Median & $75 \%$ & $90 \%$ & Max \\
\hline organic & 50 & - & 4.6 & 15.7 & 17.9 & 18.5 & 18.9 & 19.4 & 20.3 \\
\hline food waste & 20 & - & 7.9 & 8.8 & 10.8 & 13.8 & 18.5 & 19.4 & 24.8 \\
\hline gardening waste & 20 & - & 6.4 & 7.0 & 10.8 & 12.8 & 16.5 & 18.4 & 19.5 \\
\hline paper \& cardboard & 66 & - & 6.7 & 10.8 & 11.5 & 13.4 & 15.0 & 17.3 & 23.0 \\
\hline composites & 39 & - & 7.9 & 13.9 & 14.7 & 18.0 & 20.9 & 24.2 & 32.1 \\
\hline plastic & 74 & - & 10.8 & 12.4 & 21.5 & 30.5 & 36.6 & 42.2 & 45.5 \\
\hline combustibles & 91 & - & 6.0 & 13.4 & 16.3 & 19.4 & 22.5 & 25.7 & 37.4 \\
\hline metal & 11 & - & -0.1 & -0.1 & 0.0 & 0.0 & 0.0 & 9.9 & 10.7 \\
\hline glass & 9 & - & 0.0 & 0.0 & 0.0 & 0.0 & 0.3 & 0.7 & 0.7 \\
\hline inert & 12 & - & 0.0 & 0.0 & 0.0 & 0.0 & 1.8 & 16.1 & 18.5 \\
\hline $\operatorname{mix}$ & 57 & - & 0.0 & 4.9 & 8.5 & 14.4 & 19.0 & 24.1 & 31.3 \\
\hline
\end{tabular}

$\left.{ }^{*}\right)$ number of data points

$\left.{ }^{* *}\right)$ number of values below the detection limit 
Value ranges for $\mathrm{Li}$

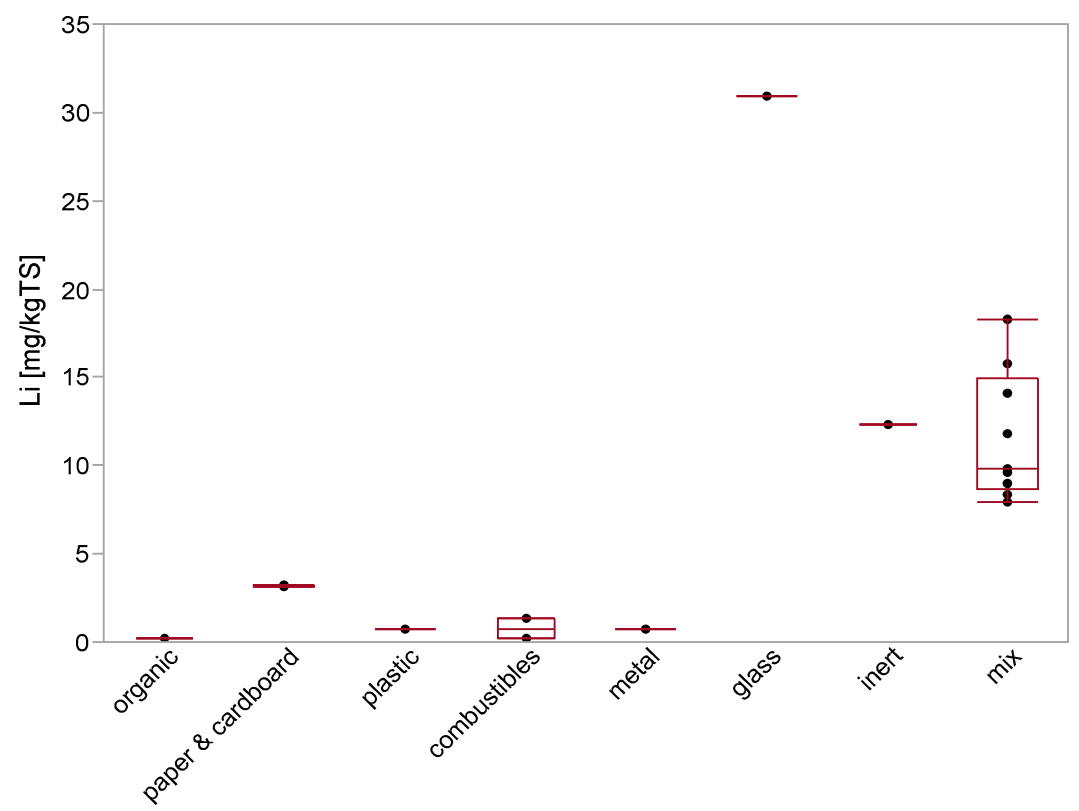

Waste Material Fractions

\section{Quantiles [mg/kgTS]}

\begin{tabular}{|c|c|c|c|c|c|c|c|c|c|}
\hline $\begin{array}{l}\text { Waste Material } \\
\text { Fraction }\end{array}$ & n_data* & $\mathrm{n}_{-}<\mathrm{DL}$ ** & Min & $10 \%$ & $25 \%$ & Median & $75 \%$ & $90 \%$ & $\operatorname{Max}$ \\
\hline organic & 1 & 1 & 0.20 & 0.20 & 0.20 & 0.20 & 0.20 & 0.20 & 0.20 \\
\hline food waste & - & - & - & - & - & - & - & - & - \\
\hline gardening waste & - & - & - & - & - & - & - & - & - \\
\hline paper \& cardboard & 2 & - & 3.14 & 3.14 & 3.14 & 3.18 & 3.22 & 3.22 & 3.22 \\
\hline composites & - & - & - & - & - & - & - & - & - \\
\hline plastic & 1 & - & 0.69 & 0.69 & 0.69 & 0.69 & 0.69 & 0.69 & 0.69 \\
\hline combustibles & 2 & 1 & 0.20 & 0.20 & 0.20 & 0.77 & 1.33 & 1.33 & 1.33 \\
\hline metal & 1 & 1 & 0.70 & 0.70 & 0.70 & 0.70 & 0.70 & 0.70 & 0.70 \\
\hline glass & 1 & - & 30.90 & 30.90 & 30.90 & 30.90 & 30.90 & 30.90 & 30.90 \\
\hline inert & 1 & - & 12.30 & 12.30 & 12.30 & 12.30 & 12.30 & 12.30 & 12.30 \\
\hline $\operatorname{mix}$ & 9 & - & 7.89 & 7.89 & 8.70 & 9.86 & 14.94 & 18.31 & 18.31 \\
\hline
\end{tabular}

*) number of data points

$\left.{ }^{\star *}\right)$ number of values below the detection limit 
Value ranges for $\mathrm{Mg}$

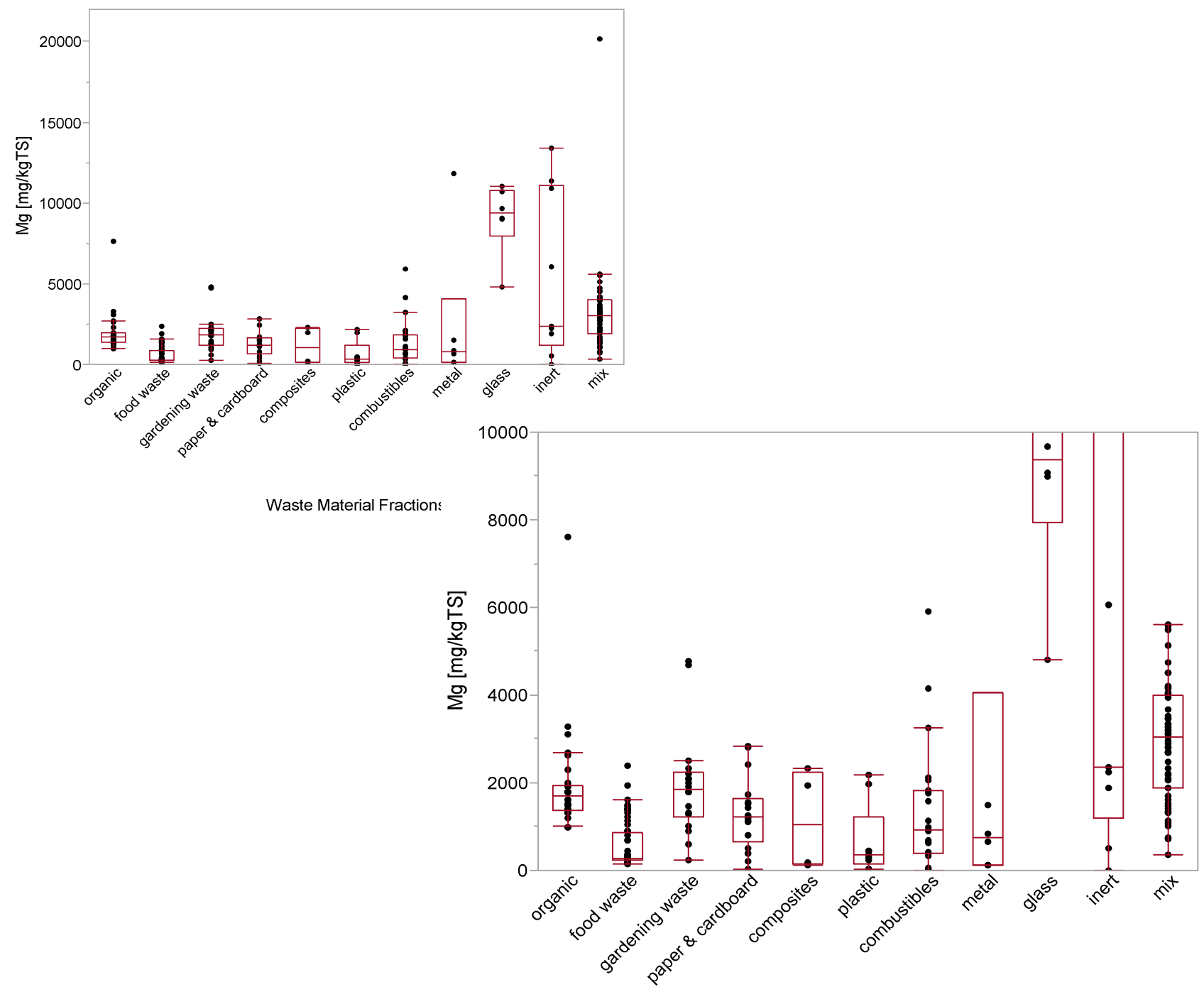

Quantiles [mg/kgTS]

Waste Material Fractions

\begin{tabular}{|c|c|c|c|c|c|c|c|c|c|}
\hline $\begin{array}{c}\text { Waste Material } \\
\text { Fraction }\end{array}$ & n_data* & $n_{-}<D L^{* *}$ & Min & $10 \%$ & $25 \%$ & Median & $75 \%$ & $90 \%$ & $\operatorname{Max}$ \\
\hline organic & 30 & - & 1000 & 1020 & 1375 & 1695 & 1949 & 3060 & 7598 \\
\hline food waste & 60 & - & 136 & 188 & 236 & 274 & 881 & 1400 & 2386 \\
\hline gardening waste & 18 & - & 239 & 564 & 1209 & 1850 & 2230 & 4708 & 4780 \\
\hline paper \& cardboard & 17 & - & 43 & 169 & 651 & 1210 & 1645 & 2817 & 2845 \\
\hline composites & 4 & - & 127 & 127 & 140 & 1060 & 2233 & 2330 & 2330 \\
\hline plastic & 9 & - & 19 & 19 & 142 & 344 & 1213 & 2170 & 2170 \\
\hline combustibles & 23 & - & 13 & 21 & 375 & 917 & 1820 & 3792 & 5920 \\
\hline metal & 6 & - & 105 & 105 & 119 & 756 & 4060 & 11800 & 11800 \\
\hline glass & 6 & - & 4800 & 4800 & 7949 & 9370 & 10780 & 11020 & 11020 \\
\hline inert & 9 & - & 0 & 0 & 1200 & 2350 & 11125 & 13400 & 13400 \\
\hline $\operatorname{mix}$ & 55 & - & 345 & 1117 & 1874 & 3039 & 4000 & 4903 & 20160 \\
\hline
\end{tabular}

*) number of data points

${ }^{* *}$ ) number of values below the detection limit 
Value ranges for $\mathrm{Mn}$

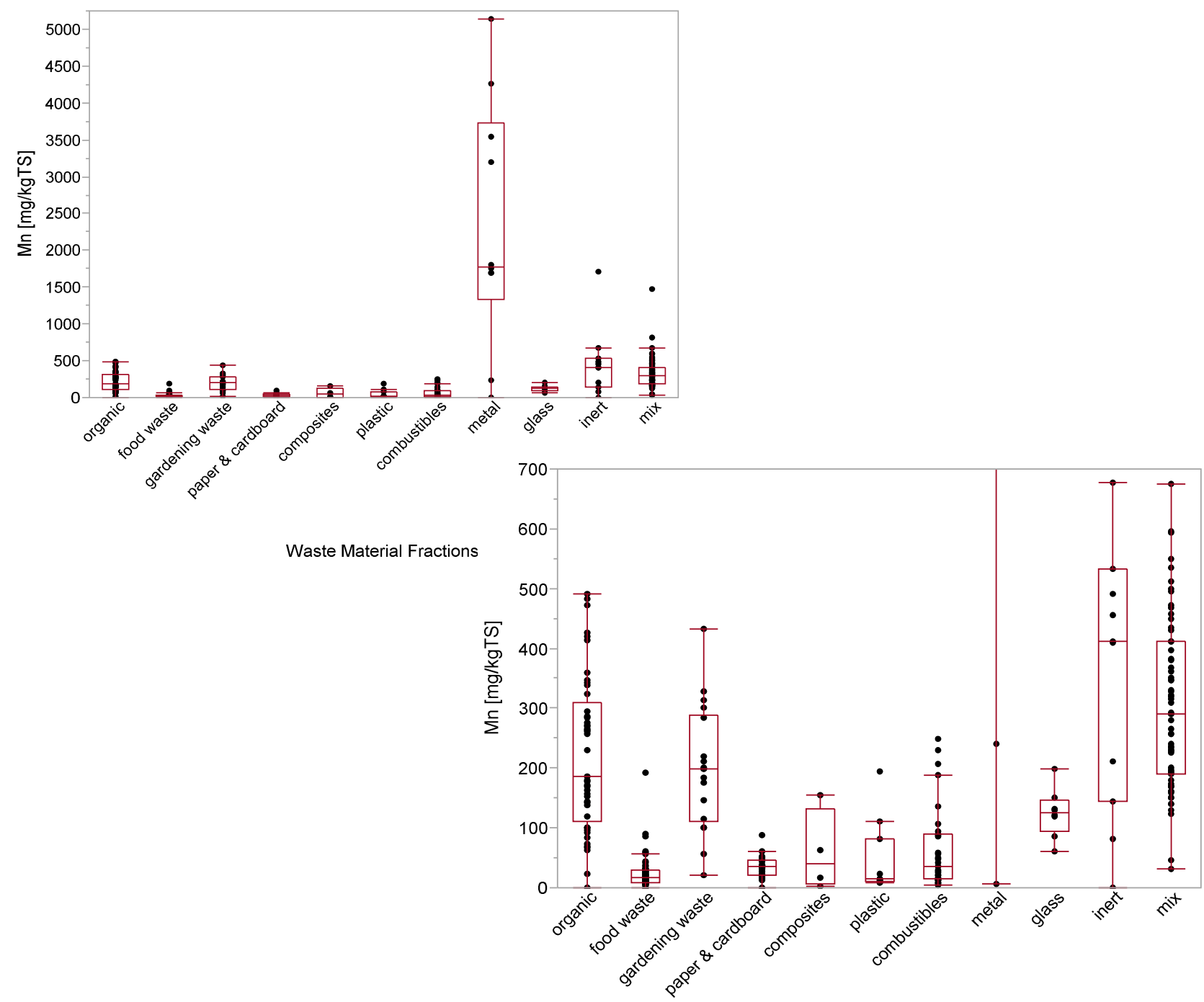

Quantiles [mg/kgTS]

Waste Material Fractions

\begin{tabular}{|c|c|c|c|c|c|c|c|c|c|}
\hline $\begin{array}{c}\text { Waste Material } \\
\text { Fraction }\end{array}$ & n_data* & $\mathrm{n}_{-}<\mathrm{DL}^{* *}$ & Min & $10 \%$ & $25 \%$ & Median & $75 \%$ & $90 \%$ & $\operatorname{Max}$ \\
\hline organic & 45 & - & 0.0 & 67.8 & 110.7 & 185.5 & 308.6 & 422.2 & 490.6 \\
\hline food waste & 58 & - & 0.0 & 5.9 & 9.2 & 16.5 & 28.4 & 56.0 & 193.0 \\
\hline gardening waste & 18 & - & 21.6 & 52.6 & 111.3 & 198.6 & 287.9 & 338.9 & 433.0 \\
\hline paper \& cardboard & 22 & - & 0.0 & 13.2 & 20.3 & 34.7 & 45.3 & 58.3 & 88.2 \\
\hline composites & 4 & - & 2.2 & 2.2 & 5.7 & 39.5 & 132.0 & 155.0 & 155.0 \\
\hline plastic & 11 & - & 7.7 & 7.7 & 10.0 & 14.0 & 82.0 & 178.2 & 195.0 \\
\hline combustibles & 31 & - & 4.8 & 8.1 & 15.0 & 36.0 & 89.0 & 202.6 & 248.0 \\
\hline metal & 10 & - & 6.3 & 29.7 & 1327.5 & 1775.0 & 3722.5 & 5053.0 & 5140.0 \\
\hline glass & 8 & - & 61.0 & 61.0 & 93.8 & 125.5 & 145.3 & 199.0 & 199.0 \\
\hline inert & 11 & - & 0.0 & 16.4 & 145.0 & 412.0 & 532.0 & 1503.4 & 1710.0 \\
\hline $\operatorname{mix}$ & 68 & - & 30.9 & 149.0 & 190.2 & 290.2 & 412.0 & 536.7 & 1476.0 \\
\hline
\end{tabular}

*) number of data points

${ }^{* *}$ ) number of values below the detection limit 
Value ranges for Mo

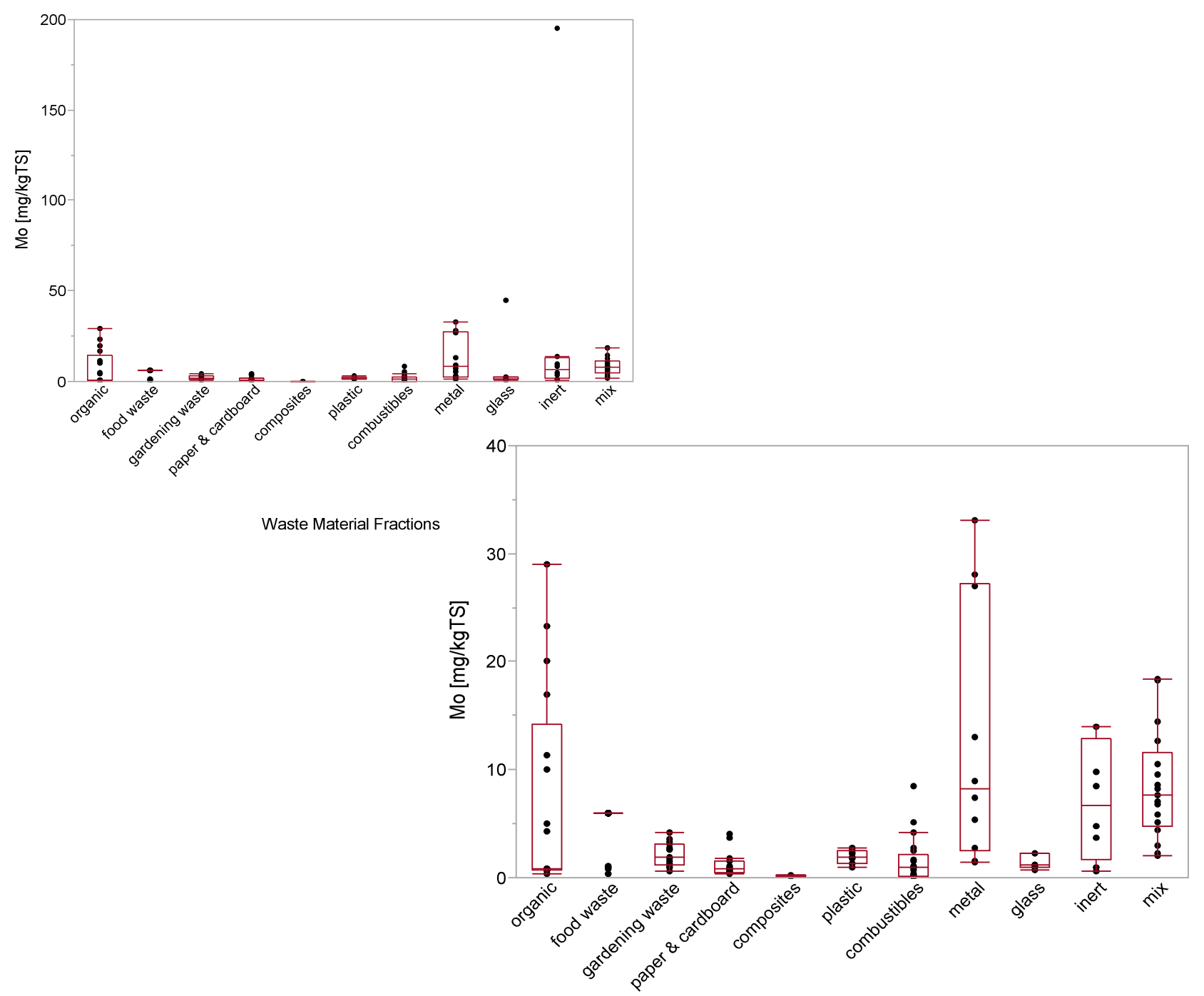

Quantiles [mg/kgTS]

Waste Material Fractions

\begin{tabular}{|c|c|c|c|c|c|c|c|c|c|}
\hline $\begin{array}{c}\text { Waste Material } \\
\text { Fraction }\end{array}$ & n_data* & $n_{-}<D^{* *}$ & Min & $10 \%$ & $25 \%$ & Median & $75 \%$ & $90 \%$ & $\operatorname{Max}$ \\
\hline organic & 17 & - & 0.34 & 0.60 & 0.75 & 0.81 & 14.15 & 24.44 & 29.00 \\
\hline food waste & 44 & 41 & 0.30 & 3.55 & 6.00 & 6.00 & 6.00 & 6.00 & 6.00 \\
\hline gardening waste & 15 & 4 & 0.65 & 0.86 & 1.20 & 1.89 & 3.06 & 3.82 & 4.17 \\
\hline paper \& cardboard & 15 & 1 & 0.32 & 0.40 & 0.50 & 0.79 & 1.50 & 3.86 & 4.10 \\
\hline composites & 2 & - & 0.11 & 0.11 & 0.11 & 0.15 & 0.19 & 0.19 & 0.19 \\
\hline plastic & 7 & - & 0.92 & 0.92 & 1.30 & 1.95 & 2.50 & 2.80 & 2.80 \\
\hline combustibles & 21 & 5 & 0.12 & 0.13 & 0.17 & 1.00 & 2.10 & 4.92 & 8.50 \\
\hline metal & 10 & 2 & 1.40 & 1.42 & 2.50 & 8.20 & 27.25 & 32.59 & 33.10 \\
\hline glass & 7 & 1 & 0.75 & 0.75 & 1.00 & 1.20 & 2.30 & 45.00 & 45.00 \\
\hline inert & 8 & 1 & 0.54 & 0.54 & 1.68 & 6.67 & 12.95 & 195.00 & 195.00 \\
\hline $\operatorname{mix}$ & 17 & - & 2.00 & 2.18 & 4.75 & 7.70 & 11.61 & 18.33 & 18.42 \\
\hline
\end{tabular}

*) number of data points

${ }^{* *}$ ) number of values below the detection limit 


\section{Value ranges for $\mathrm{N}$}

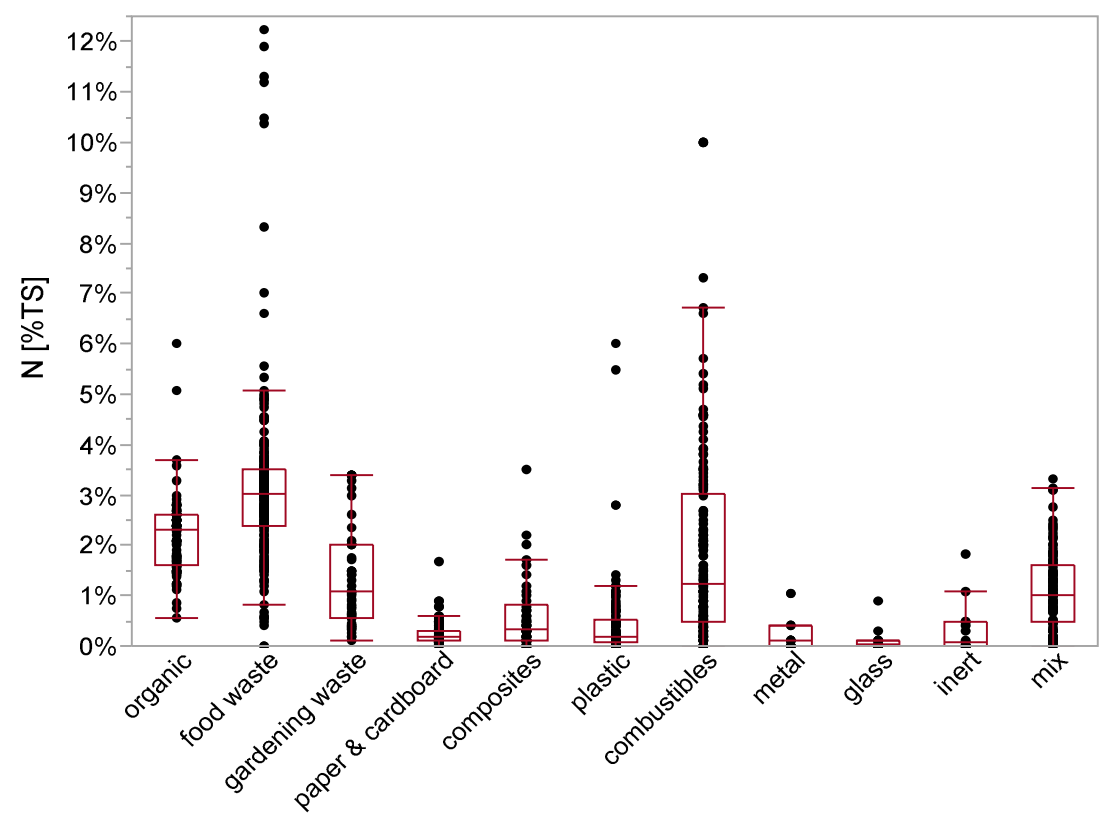

Waste Material Fractions

\section{Quantiles [\%TS]}

\section{Waste Material}

\begin{tabular}{lrrrrrrrrr}
\multicolumn{1}{c}{ Fraction } & $\mathbf{n}$ data*$^{*}$ & $\mathbf{n}<\mathbf{D L}^{* *}$ & Min & $\mathbf{1 0 \%}$ & $\mathbf{2 5 \%}$ & Median & $\mathbf{7 5 \%}$ & $\mathbf{9 0 \%}$ & $\mathbf{M a x}$ \\
\hline organic & 104 & - & $0.56 \%$ & $1.40 \%$ & $1.61 \%$ & $2.30 \%$ & $2.60 \%$ & $2.80 \%$ & $6.00 \%$ \\
food waste & 212 & - & $0.00 \%$ & $1.59 \%$ & $2.39 \%$ & $3.01 \%$ & $3.50 \%$ & $4.55 \%$ & $12.23 \%$ \\
gardening waste & 49 & - & $0.10 \%$ & $0.33 \%$ & $0.57 \%$ & $1.09 \%$ & $2.00 \%$ & $3.40 \%$ & $3.40 \%$ \\
paper \& cardboard & 114 & 1 & $0.00 \%$ & $0.09 \%$ & $0.10 \%$ & $0.20 \%$ & $0.30 \%$ & $0.49 \%$ & $1.69 \%$ \\
composites & 42 & - & $0.00 \%$ & $0.00 \%$ & $0.12 \%$ & $0.35 \%$ & $0.83 \%$ & $1.67 \%$ & $3.50 \%$ \\
plastic & 116 & 1 & $0.00 \%$ & $0.00 \%$ & $0.06 \%$ & $0.20 \%$ & $0.53 \%$ & $1.03 \%$ & $6.00 \%$ \\
combustibles & 146 & - & $0.00 \%$ & $0.18 \%$ & $0.47 \%$ & $1.22 \%$ & $3.03 \%$ & $4.60 \%$ & $10.00 \%$ \\
metal & 13 & 3 & $0.00 \%$ & $0.00 \%$ & $0.00 \%$ & $0.10 \%$ & $0.40 \%$ & $1.05 \%$ & $1.05 \%$ \\
glass & 13 & 3 & $0.00 \%$ & $0.00 \%$ & $0.00 \%$ & $0.04 \%$ & $0.10 \%$ & $0.65 \%$ & $0.88 \%$ \\
inert & 14 & - & $0.00 \%$ & $0.00 \%$ & $0.00 \%$ & $0.08 \%$ & $0.50 \%$ & $1.46 \%$ & $1.81 \%$ \\
mix & 117 & - & $0.00 \%$ & $0.12 \%$ & $0.48 \%$ & $1.05 \%$ & $1.67 \%$ & $2.33 \%$ & $13.16 \%$ \\
\hline Total & 940 & 8 & & & & & & &
\end{tabular}

*) number of data points

${ }^{* *}$ ) number of values below the detection limit 


\section{Value ranges for $\mathrm{Na}$}

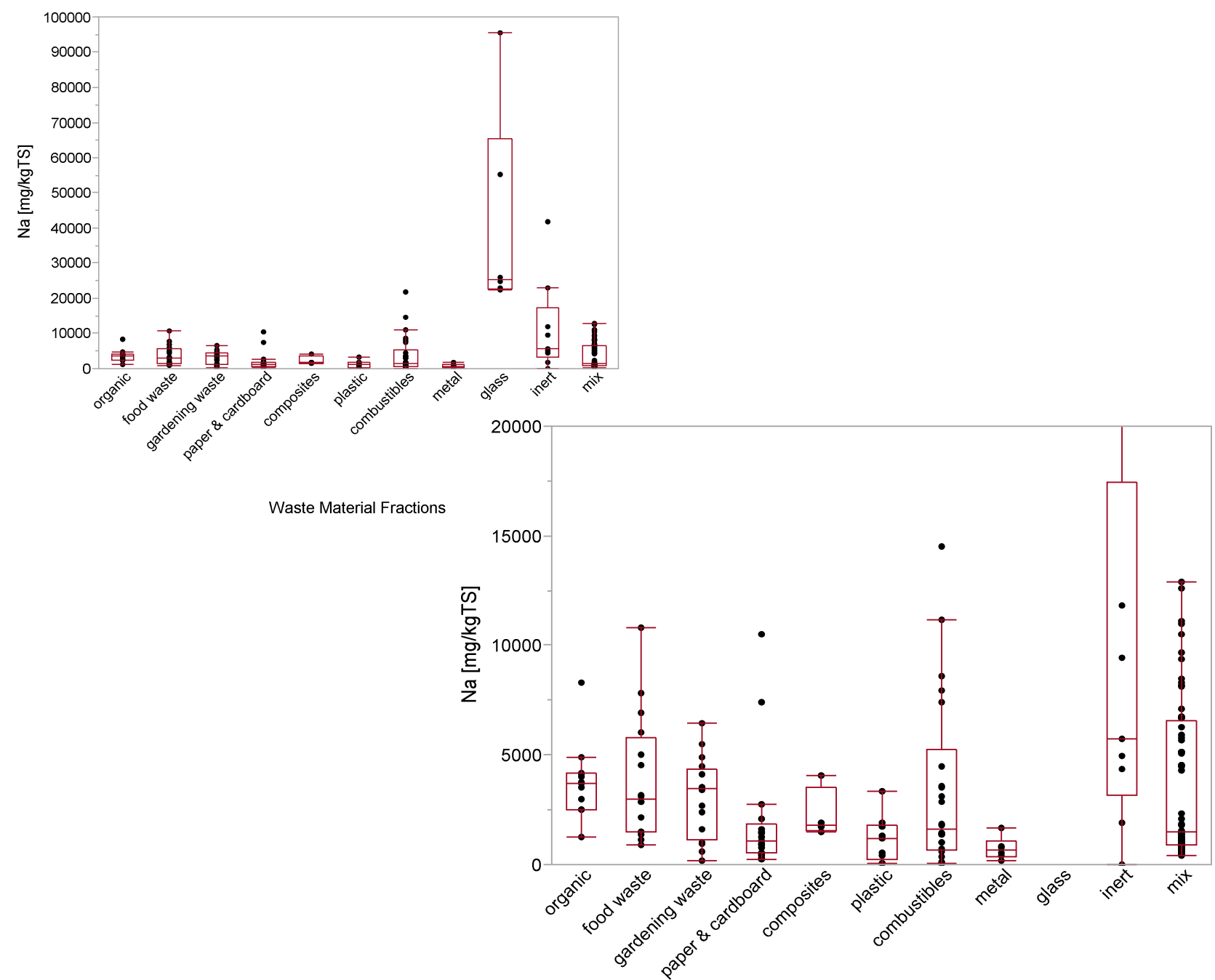

Waste Material Fractions

\section{Quantiles [mg/kgTS]}

\section{Waste Material}

\begin{tabular}{lrrrrrrrrr}
\multicolumn{1}{c}{ Fraction } & $\mathbf{n}_{\mathbf{d}} \mathbf{d a t a}^{*}$ & $\mathbf{n} \_\mathbf{D L}^{* *}$ & \multicolumn{1}{c}{ Min } & $\mathbf{1 0 \%}$ & $\mathbf{2 5 \%}$ & Median & $\mathbf{7 5 \%}$ & $\mathbf{9 0 \%}$ & Max \\
\hline organic & 13 & - & 1250 & 1750 & 2500 & 3720 & 4150 & 6940 & 8300 \\
food waste & 16 & - & 877 & 1058 & 1483 & 2980 & 5767 & 8729 & 10800 \\
gardening waste & 16 & - & 168 & 470 & 1150 & 3441 & 4375 & 5782 & 6423 \\
paper \& cardboard & 17 & - & 246 & 272 & 511 & 1090 & 1835 & 8020 & 10500 \\
composites & 4 & - & 1500 & 1500 & 1560 & 1820 & 3520 & 4060 & 4060 \\
plastic & 9 & - & 36 & 36 & 250 & 1170 & 1810 & 3340 & 3340 \\
combustibles & 26 & - & 39 & 52 & 671 & 1630 & 5225 & 12162 & 21900 \\
metal & 6 & - & 165 & 165 & 334 & 648 & 1054 & 1670 & 1670 \\
glass & 6 & - & 22400 & 22400 & 22820 & 25500 & 65343 & 95500 & 95500 \\
inert & 9 & - & 0 & 0 & 3135 & 5760 & 17411 & 41700 & 41700 \\
mix & 64 & - & 437 & 605 & 890 & 1502 & 6580 & 9534 & 12876 \\
\hline Total & 186 & 0 & & & & & & &
\end{tabular}

*) number of data points

${ }^{* *}$ ) number of values below the detection limit 


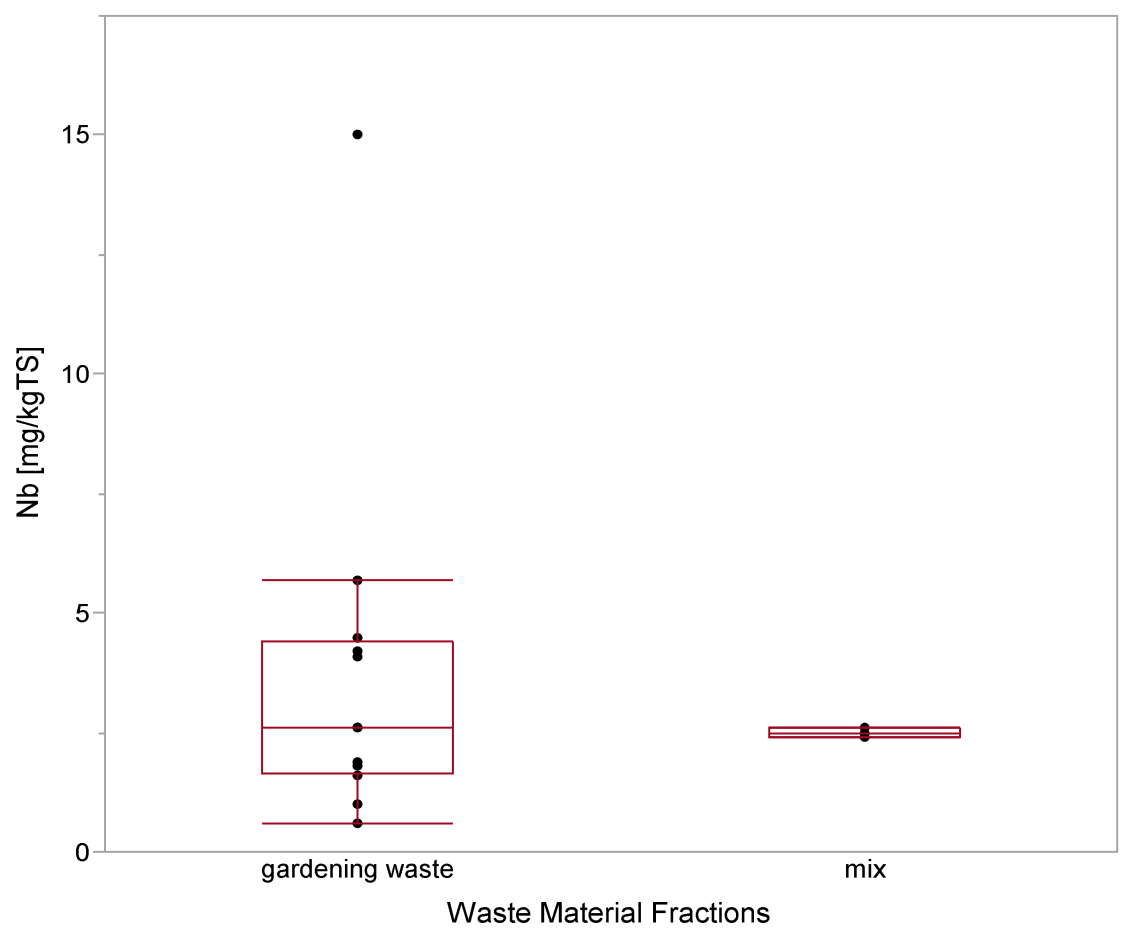

\section{Quantiles [mg/kgTS]}

\section{Waste Material}

Fraction

n_data* n_<DL** $^{*}$

Min

$10 \%$

$25 \%$

Median

$75 \%$

$90 \%$

$\operatorname{Max}$

organic

food waste

gardening waste

12

$11 \quad 0.600$

0.720

1.650

2.600

4.425

12.210

15.000

paper \& cardboaro

composites

plastic

combustibles

metal

glass

inert

mix

2.400

2.400

2.400

2.500

2.600

2.600

2.600

*) number of data points

${ }^{* *}$ ) number of values below the detection limit 


\section{Value ranges for $\mathrm{Ni}$}

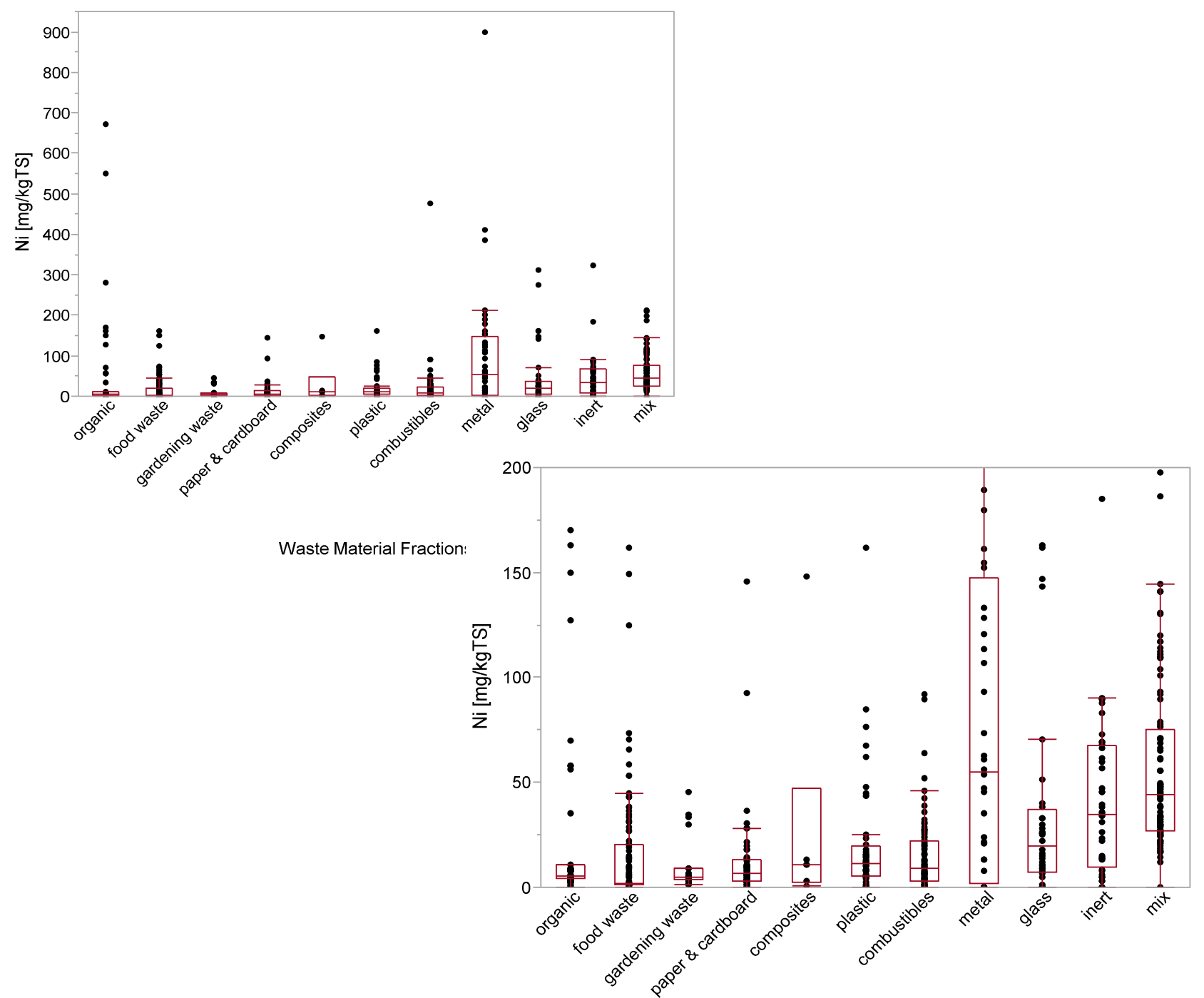

\section{Quantiles [mg/kgTS]}

Waste Material Fractions

\begin{tabular}{|c|c|c|c|c|c|c|c|c|c|}
\hline $\begin{array}{c}\text { Waste Material } \\
\text { Fraction }\end{array}$ & n_data* & $\mathrm{n}_{-}<\mathrm{DL} * *$ & Min & $10 \%$ & $25 \%$ & Median & $75 \%$ & $90 \%$ & $\operatorname{Max}$ \\
\hline organic & 51 & - & 0.0 & 2.3 & 3.9 & 5.6 & 10.5 & 160.4 & 673.0 \\
\hline food waste & 99 & 24 & 0.0 & 1.0 & 1.0 & 2.0 & 20.4 & 44.9 & 162.0 \\
\hline gardening waste & 20 & - & 1.0 & 1.6 & 3.5 & 4.8 & 9.0 & 34.6 & 45.6 \\
\hline paper \& cardboard & 57 & 2 & 0.0 & 0.9 & 3.2 & 6.5 & 13.3 & 28.0 & 145.6 \\
\hline composites & 6 & - & 0.5 & 0.5 & 2.2 & 10.8 & 47.1 & 148.3 & 148.3 \\
\hline plastic & 44 & - & 0.0 & 0.2 & 5.4 & 11.6 & 19.6 & 64.9 & 161.8 \\
\hline combustibles & 97 & - & 0.0 & 0.0 & 3.2 & 8.8 & 22.0 & 33.2 & 476.0 \\
\hline metal & 40 & - & 0.0 & 0.0 & 2.0 & 55.0 & 147.3 & 211.4 & 900.0 \\
\hline glass & 40 & - & 0.0 & 0.0 & 6.9 & 19.9 & 37.1 & 160.5 & 313.0 \\
\hline inert & 44 & - & 0.0 & 1.6 & 9.3 & 34.7 & 67.7 & 89.3 & 322.0 \\
\hline $\operatorname{mix}$ & 104 & - & 0.0 & 20.5 & 26.8 & 44.2 & 75.2 & 118.5 & 211.3 \\
\hline
\end{tabular}

*) number of data points

${ }^{* *}$ ) number of values below the detection limit 


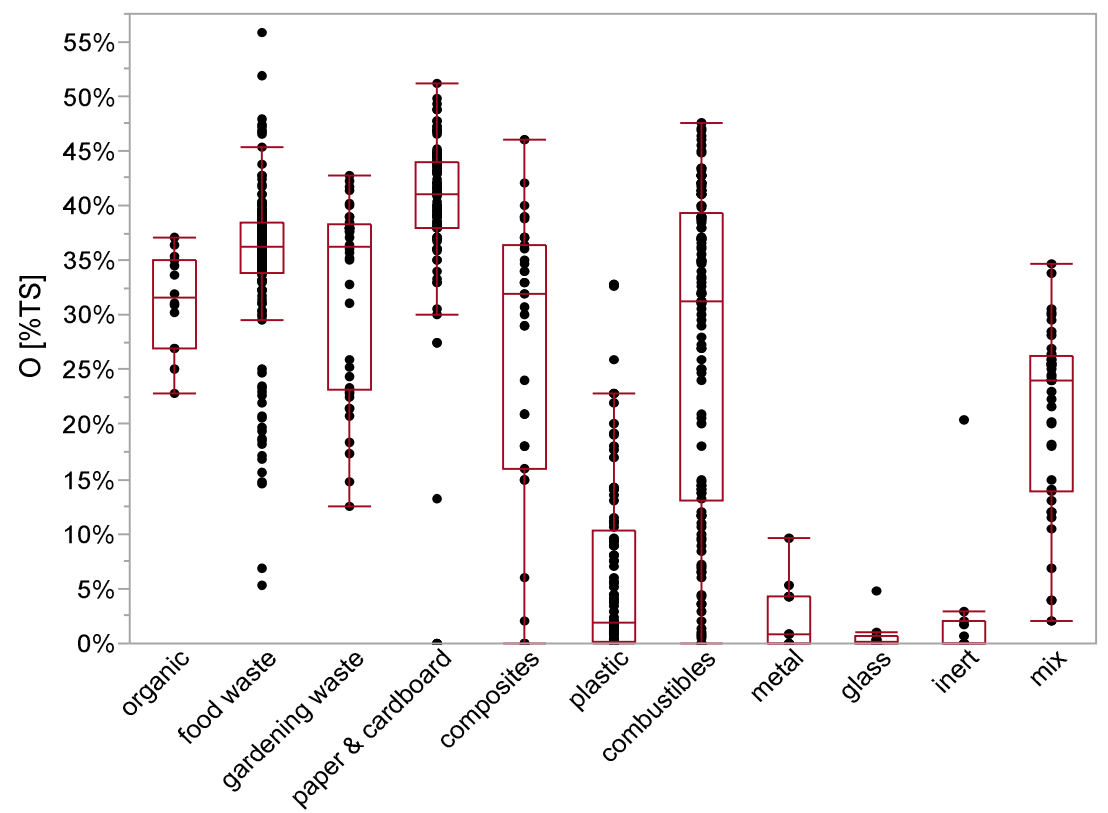

Waste Material Fractions

\section{Quantiles [\%TS]}

\begin{tabular}{|c|c|c|c|c|c|c|c|c|c|}
\hline $\begin{array}{l}\text { Waste Material } \\
\text { Fraction }\end{array}$ & n_data* & $\mathrm{n} \_$<DL** & Min & $10 \%$ & $25 \%$ & Median & $75 \%$ & $90 \%$ & Max \\
\hline organic & 14 & - & $22.9 \%$ & $24.0 \%$ & $26.9 \%$ & $31.5 \%$ & $35.1 \%$ & $36.7 \%$ & $37.0 \%$ \\
\hline food waste & 173 & - & $5.3 \%$ & $23.1 \%$ & $33.8 \%$ & $36.2 \%$ & $38.5 \%$ & $40.7 \%$ & $55.8 \%$ \\
\hline gardening waste & 40 & - & $12.6 \%$ & $18.6 \%$ & $23.1 \%$ & $36.2 \%$ & $38.2 \%$ & $41.2 \%$ & $42.7 \%$ \\
\hline paper \& cardboard & 112 & - & $0.0 \%$ & $32.9 \%$ & $38.0 \%$ & $41.1 \%$ & $44.0 \%$ & $46.8 \%$ & $51.2 \%$ \\
\hline composites & 39 & - & $0.0 \%$ & $0.0 \%$ & $16.0 \%$ & $32.0 \%$ & $36.4 \%$ & $40.0 \%$ & $46.0 \%$ \\
\hline plastic & 112 & - & $0.0 \%$ & $0.0 \%$ & $0.2 \%$ & $1.9 \%$ & $10.3 \%$ & $19.1 \%$ & $32.8 \%$ \\
\hline combustibles & 130 & - & $0.0 \%$ & $3.7 \%$ & $13.0 \%$ & $31.3 \%$ & $39.2 \%$ & $42.7 \%$ & $47.6 \%$ \\
\hline metal & 13 & - & $0.0 \%$ & $0.0 \%$ & $0.0 \%$ & $0.8 \%$ & $4.3 \%$ & $7.9 \%$ & $9.6 \%$ \\
\hline glass & 12 & - & $0.0 \%$ & $0.0 \%$ & $0.0 \%$ & $0.2 \%$ & $0.6 \%$ & $3.7 \%$ & $4.8 \%$ \\
\hline inert & 11 & - & $0.0 \%$ & $0.0 \%$ & $0.0 \%$ & $0.0 \%$ & $2.0 \%$ & $17.0 \%$ & $20.5 \%$ \\
\hline $\operatorname{mix}$ & 43 & - & $2.0 \%$ & $5.1 \%$ & $13.8 \%$ & $24.0 \%$ & $26.3 \%$ & $30.2 \%$ & $34.6 \%$ \\
\hline
\end{tabular}

*) number of data points

${ }^{* *}$ ) number of values below the detection limit 


\section{Value ranges for $P$}

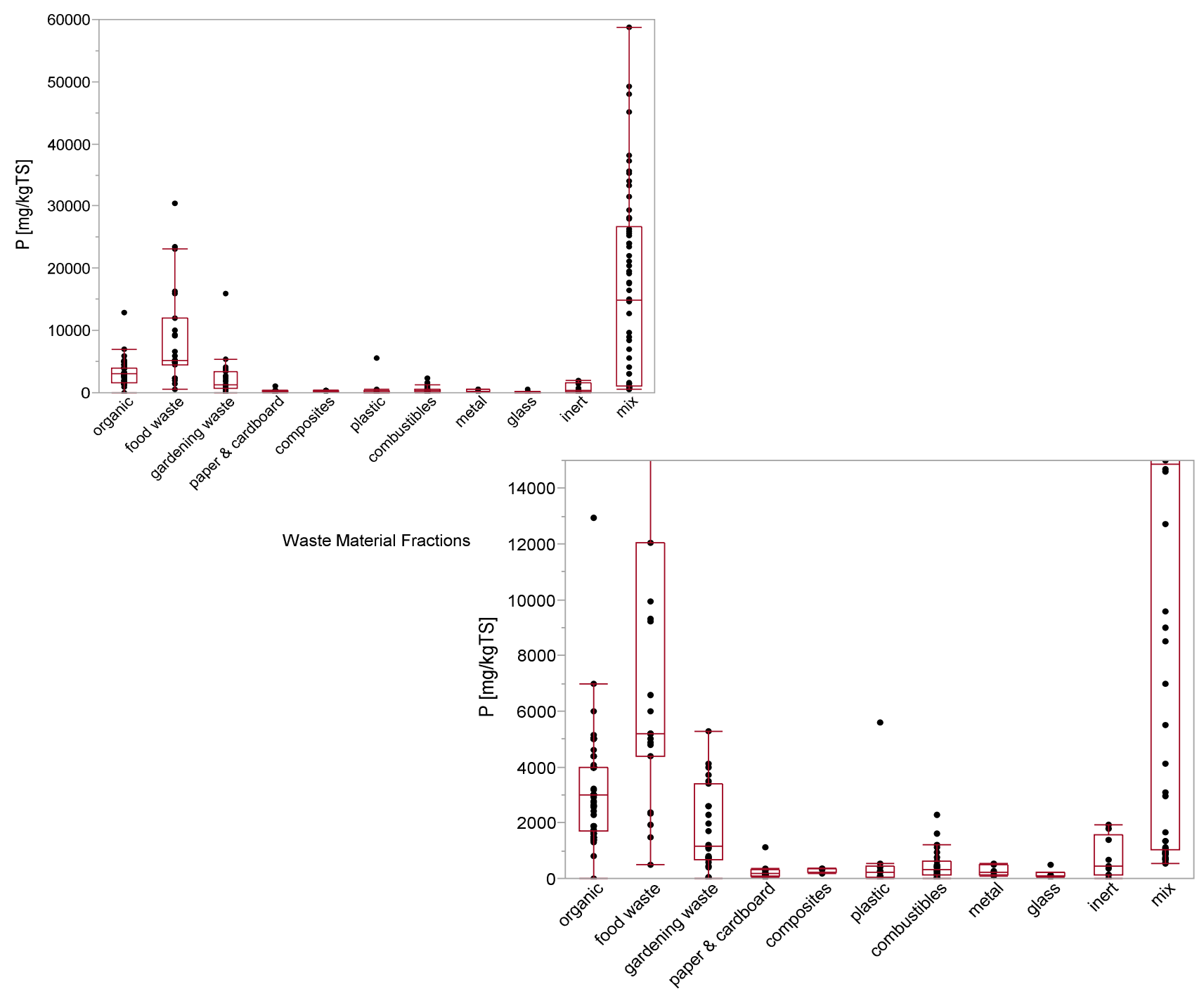

Quantiles [mg/kgTS]

Waste Material Fractions

\begin{tabular}{|c|c|c|c|c|c|c|c|c|c|}
\hline $\begin{array}{l}\text { Waste Material } \\
\text { Fraction }\end{array}$ & n_data* & $n_{-}<D L^{* *}$ & Min & $10 \%$ & $25 \%$ & Median & $75 \%$ & $90 \%$ & $\operatorname{Max}$ \\
\hline organic & 85 & - & 5 & 1438 & 1700 & 3000 & 4000 & 5000 & 12950 \\
\hline food waste & 23 & - & 489 & 1659 & 4400 & 5200 & 12045 & 23386 & 30455 \\
\hline gardening waste & 27 & - & 21 & 28 & 666 & 1184 & 3400 & 4340 & 15900 \\
\hline paper \& cardboard & 18 & - & 38 & 43 & 109 & 164 & 291 & 422 & 1100 \\
\hline composites & 4 & - & 189 & 189 & 224 & 340 & 373 & 380 & 380 \\
\hline plastic & 10 & - & 15 & 16 & 63 & 244 & 445 & 5104 & 5610 \\
\hline combustibles & 27 & - & 13 & 30 & 148 & 300 & 608 & 1294 & 2300 \\
\hline metal & 6 & - & 110 & 110 & 139 & 232 & 498 & 551 & 551 \\
\hline glass & 6 & 1 & 64 & 64 & 70 & 98 & 212 & 480 & 480 \\
\hline inert & 9 & - & 0 & 0 & 141 & 439 & 1585 & 1920 & 1920 \\
\hline $\operatorname{mix}$ & 62 & - & 550 & 736 & 1051 & 14850 & 26725 & 36750 & 58800 \\
\hline
\end{tabular}

*) number of data points

${ }^{* *}$ ) number of values below the detection limit 


\section{Value ranges for $\mathrm{Pb}$}

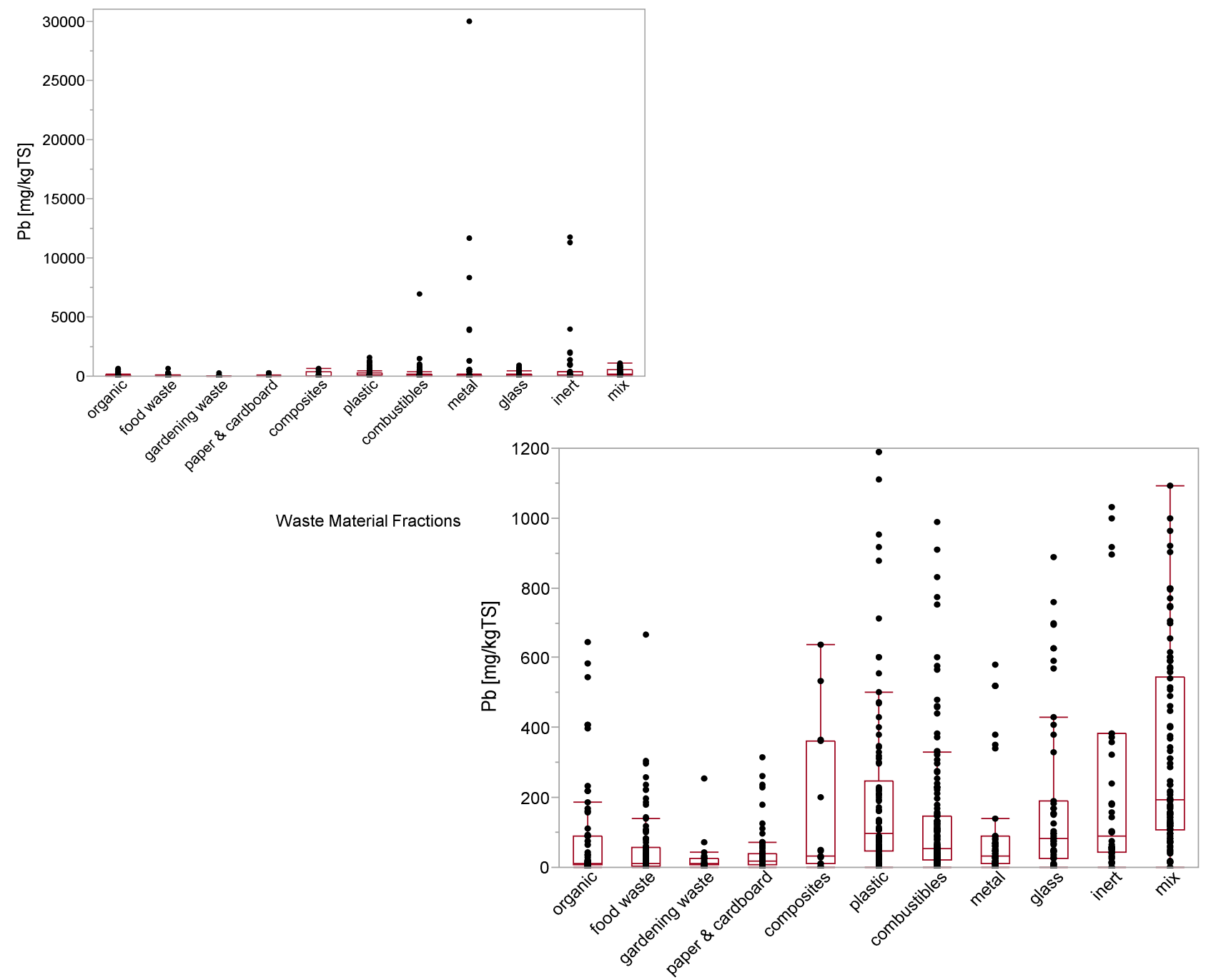

\section{Quantiles [mg/kgTS]}

Waste Material Fractions

\begin{tabular}{|c|c|c|c|c|c|c|c|c|c|}
\hline $\begin{array}{c}\text { Waste Material } \\
\text { Fraction }\end{array}$ & n_data* & $\mathrm{n}_{-}<\mathrm{DL} * *$ & Min & $10 \%$ & $25 \%$ & Median & $75 \%$ & $90 \%$ & $\operatorname{Max}$ \\
\hline organic & 68 & - & 0.0 & 3.4 & 6.7 & 10.7 & 89.1 & 250.3 & 643.2 \\
\hline food waste & 105 & 40 & 0.0 & 2.0 & 2.0 & 11.0 & 56.9 & 157.6 & 666.9 \\
\hline gardening waste & 25 & - & 0.0 & 2.0 & 6.7 & 9.6 & 23.7 & 54.8 & 255.3 \\
\hline paper \& cardboard & 88 & 2 & 0.0 & 2.7 & 7.6 & 17.4 & 39.8 & 74.4 & 316.0 \\
\hline composites & 15 & - & 0.7 & 1.0 & 9.0 & 34.0 & 363.3 & 575.2 & 638.0 \\
\hline plastic & 102 & - & 0.8 & 21.9 & 46.6 & 98.2 & 247.0 & 602.0 & 1595.0 \\
\hline combustibles & 155 & 3 & 0.0 & 9.1 & 23.0 & 53.8 & 147.0 & 405.2 & 6900.0 \\
\hline metal & 67 & 1 & 0.0 & 0.0 & 9.0 & 33.0 & 90.0 & 1283.2 & 30010.0 \\
\hline glass & 51 & - & 0.0 & 0.0 & 24.6 & 81.5 & 189.1 & 628.0 & 889.0 \\
\hline inert & 50 & - & 0.0 & 13.1 & 41.3 & 88.4 & 382.3 & 1910.5 & 11740.0 \\
\hline $\operatorname{mix}$ & 102 & 3 & 0.0 & 47.4 & 107.1 & 191.9 & 544.6 & 764.0 & 1092.1 \\
\hline
\end{tabular}

*) number of data points

$\left.{ }^{* *}\right)$ number of values below the detection limit 
Value ranges for $S$

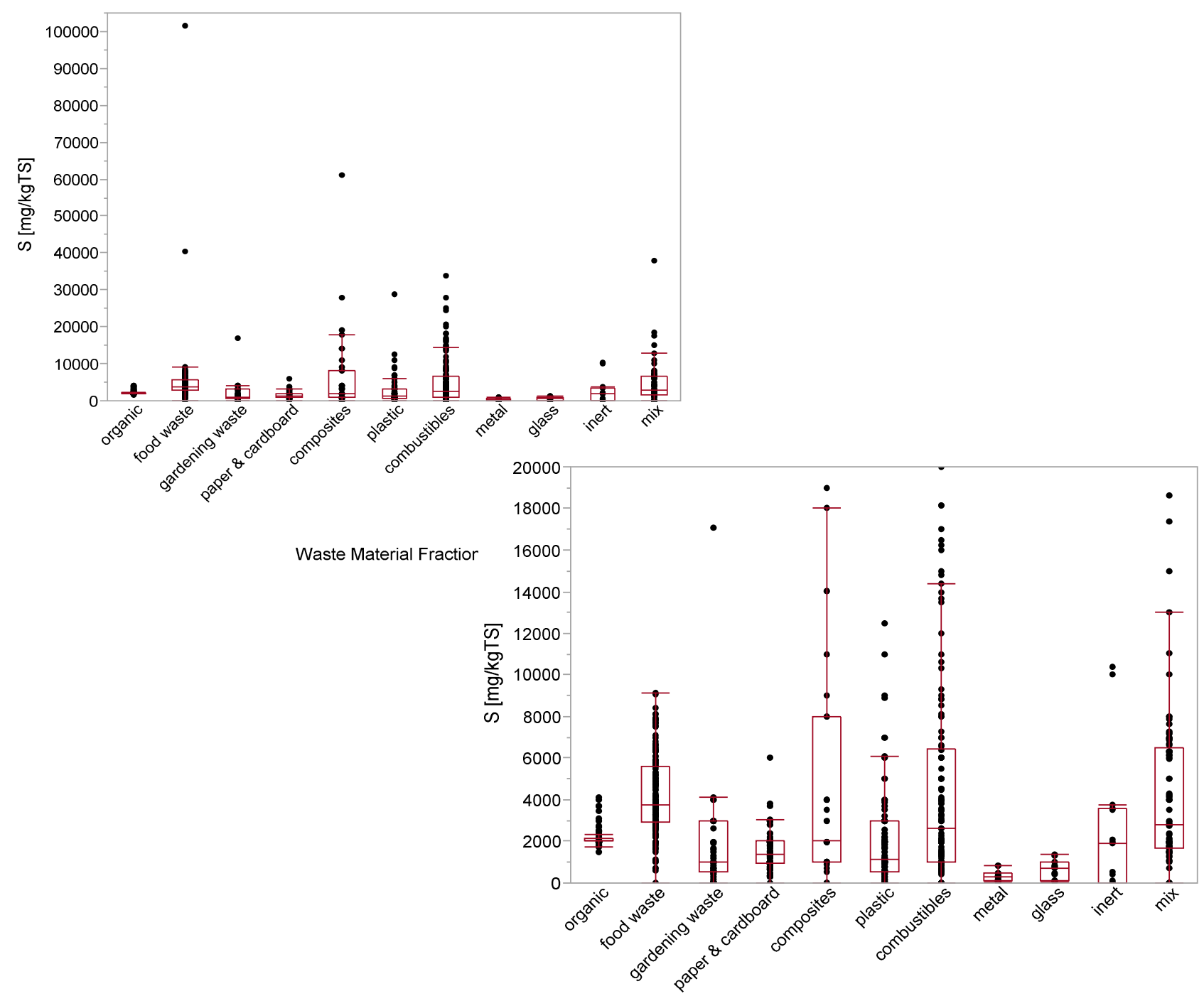

Quantiles [mg/kgTS]

Waste Material Fractions

\begin{tabular}{|c|c|c|c|c|c|c|c|c|c|}
\hline $\begin{array}{c}\text { Waste Material } \\
\text { Fraction }\end{array}$ & n_data* & $\mathrm{n}_{-}<\mathrm{DL} \mathrm{L}^{* *}$ & Min & $10 \%$ & $25 \%$ & Median & $75 \%$ & $90 \%$ & $\operatorname{Max}$ \\
\hline organic & 67 & - & 1500 & 1888 & 2000 & 2000 & 2170 & 3020 & 4100 \\
\hline food waste & 175 & - & 0 & 1960 & 2900 & 3780 & 5600 & 7510 & 101700 \\
\hline gardening waste & 39 & - & 0 & 51 & 557 & 1000 & 3000 & 4000 & 17065 \\
\hline paper \& cardboard & 81 & - & 0 & 526 & 944 & 1400 & 2000 & 3000 & 6000 \\
\hline composites & 37 & - & 0 & 0 & 1000 & 2000 & 8000 & 18200 & 61000 \\
\hline plastic & 101 & 2 & 0 & 0 & 520 & 1125 & 3000 & 6000 & 28740 \\
\hline combustibles & 142 & 3 & 0 & 587 & 1000 & 2600 & 6428 & 14654 & 34000 \\
\hline metal & 13 & 2 & 30 & 30 & 95 & 297 & 500 & 808 & 808 \\
\hline glass & 11 & - & 50 & 58 & 111 & 687 & 1000 & 1383 & 1400 \\
\hline inert & 15 & - & 0 & 0 & 0 & 1920 & 3590 & 10164 & 10410 \\
\hline $\operatorname{mix}$ & 85 & - & 0 & 419 & 1694 & 2800 & 6490 & 8006 & 38000 \\
\hline
\end{tabular}

*) number of data points

${ }^{* *}$ ) number of values below the detection limit 


\section{Value ranges for $\mathrm{Sb}$}

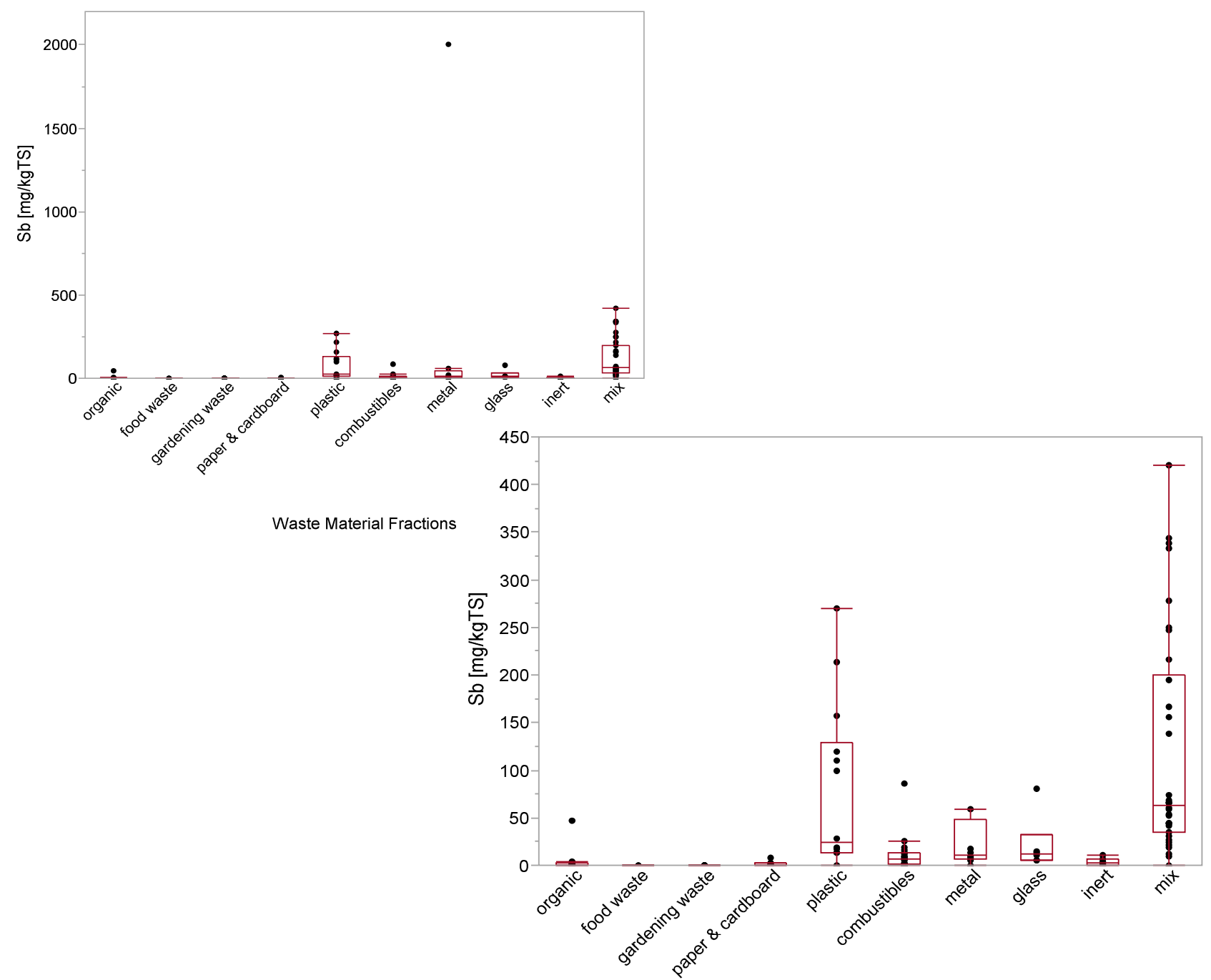

\section{Quantiles [mg/kgTS]}

Waste Material Fractions

\begin{tabular}{|c|c|c|c|c|c|c|c|c|c|}
\hline $\begin{array}{c}\text { Waste Material } \\
\text { Fraction }\end{array}$ & n_data* & $\mathrm{n}_{-}<\mathrm{DL}$ ** & Min & $10 \%$ & $25 \%$ & Median & $75 \%$ & $90 \%$ & Max \\
\hline organic & 12 & 5 & 0.02 & 0.16 & 0.50 & 0.60 & 2.60 & 34.04 & 47.00 \\
\hline food waste & 2 & 1 & 0.00 & 0.00 & 0.00 & 0.25 & 0.50 & 0.50 & 0.50 \\
\hline gardening waste & 13 & 4 & 0.00 & 0.00 & 0.00 & 0.04 & 0.11 & 0.18 & 0.20 \\
\hline paper \& cardboard & 8 & 2 & 0.00 & 0.00 & 0.20 & 0.56 & 2.45 & 7.90 & 7.90 \\
\hline composites & - & - & - & - & - & - & - & - & - \\
\hline plastic & 14 & - & 0.00 & 0.00 & 12.88 & 24.00 & 129.23 & 242.18 & 270.60 \\
\hline combustibles & 23 & - & 0.00 & 0.00 & 0.90 & 6.20 & 13.00 & 22.68 & 86.30 \\
\hline metal & 8 & 1 & 0.50 & 0.50 & 6.45 & 11.40 & 48.73 & 2000.00 & 2000.00 \\
\hline glass & 6 & - & 5.90 & 5.90 & 5.98 & 12.28 & 31.70 & 81.20 & 81.20 \\
\hline inert & 7 & 1 & 0.00 & 0.00 & 0.50 & 2.70 & 6.07 & 11.10 & 11.10 \\
\hline $\operatorname{mix}$ & 34 & - & 0.00 & 15.16 & 34.28 & 62.90 & 200.10 & 336.00 & 420.00 \\
\hline
\end{tabular}

*) number of data points

${ }^{* *}$ ) number of values below the detection limit 
Value ranges for Sc

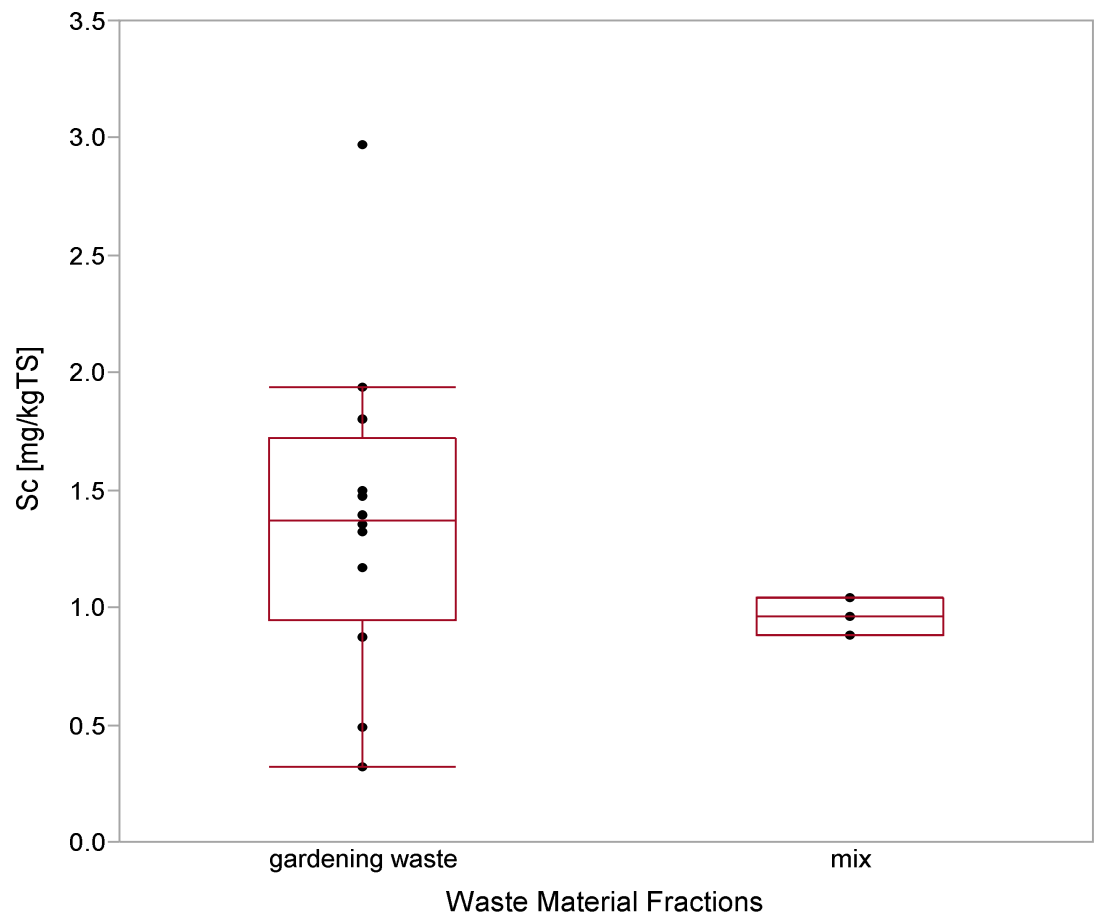

Quantiles [mg/kgTS]

\begin{tabular}{|c|c|c|c|c|c|c|c|c|c|}
\hline $\begin{array}{l}\text { Waste Material } \\
\text { Fraction }\end{array}$ & n_data* & $n_{-}<D L^{* *}$ & Min & $10 \%$ & $25 \%$ & Median & $75 \%$ & $90 \%$ & Max \\
\hline organic & - & - & - & - & - & - & - & - & - \\
\hline food waste & - & - & - & - & - & - & - & - & - \\
\hline gardening waste & 12 & & 0.32 & 0.37 & 0.95 & 1.37 & 1.73 & 2.66 & 2.97 \\
\hline paper \& cardboard & - & - & - & - & - & - & - & - & - \\
\hline composites & - & - & - & - & - & - & - & - & - \\
\hline plastic & - & - & - & - & - & - & - & - & - \\
\hline combustibles & - & - & - & - & - & - & - & - & - \\
\hline metal & - & - & - & - & - & - & - & - & - \\
\hline glass & - & - & - & - & - & - & - & - & - \\
\hline inert & - & - & - & - & - & - & - & - & - \\
\hline $\operatorname{mix}$ & 3 & & 0.88 & 0.88 & 0.88 & 0.96 & 1.04 & 1.04 & 1.04 \\
\hline Total & 15 & 0 & & & & & & & \\
\hline
\end{tabular}




\section{Value ranges for Se}

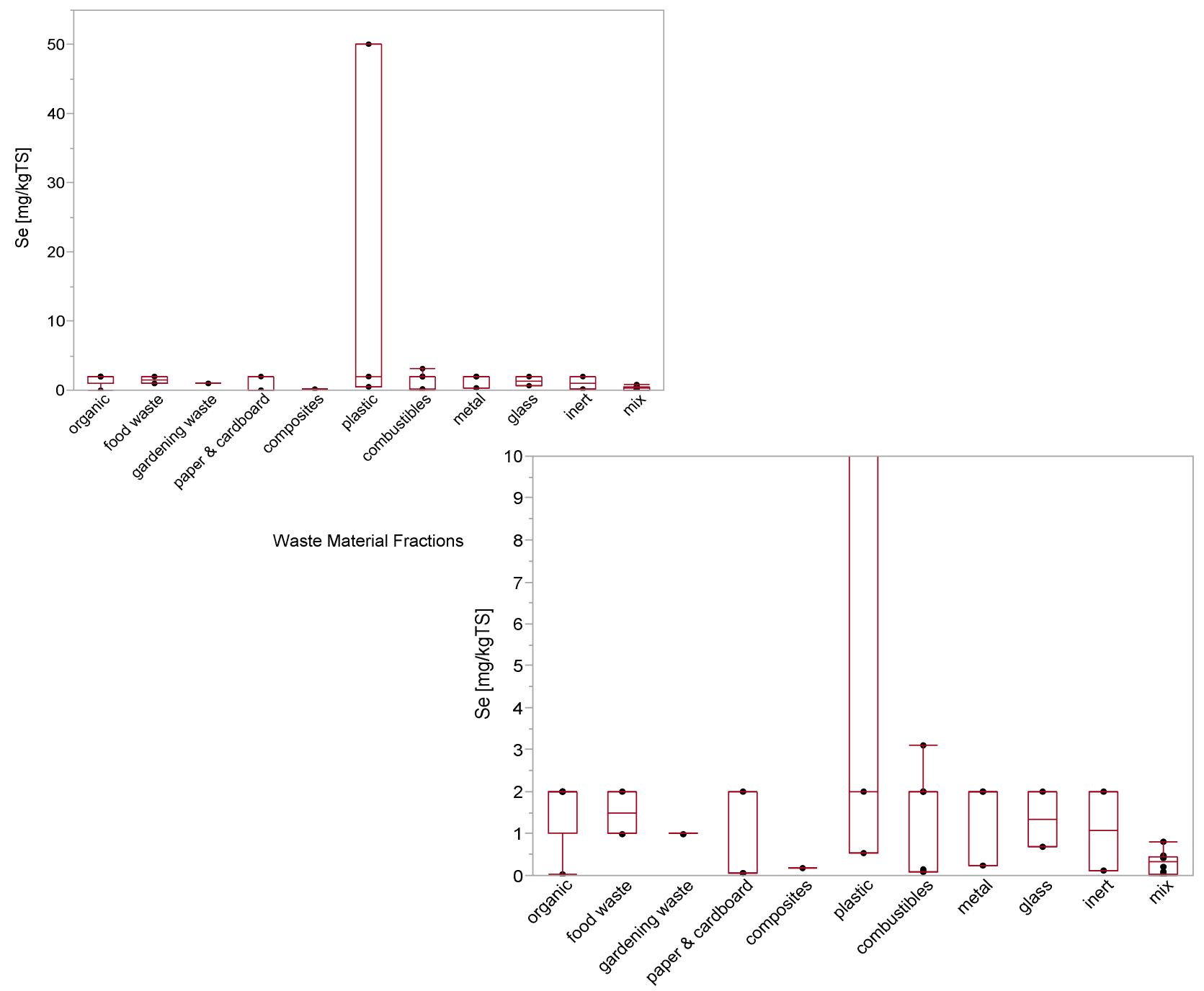

\section{Quantiles [mg/kgTS]}

Waste Material Fractions

\begin{tabular}{|c|c|c|c|c|c|c|c|c|c|}
\hline $\begin{array}{c}\text { Waste Material } \\
\text { Fraction }\end{array}$ & n_data* & $\mathrm{n}_{-}<\mathrm{DL}$ ** & Min & $10 \%$ & $25 \%$ & Median & $75 \%$ & $90 \%$ & Max \\
\hline organic & 5 & 4 & 0.04 & 0.04 & 1.02 & 2.00 & 2.00 & 2.00 & 2.00 \\
\hline food waste & 2 & 2 & 1.00 & 1.00 & 1.00 & 1.50 & 2.00 & 2.00 & 2.00 \\
\hline gardening waste & 1 & 1 & 1.00 & 1.00 & 1.00 & 1.00 & 1.00 & 1.00 & 1.00 \\
\hline paper \& cardboard & 3 & 1 & 0.06 & 0.06 & 0.06 & 0.07 & 2.00 & 2.00 & 2.00 \\
\hline composites & 1 & - & 0.17 & 0.17 & 0.17 & 0.17 & 0.17 & 0.17 & 0.17 \\
\hline plastic & 3 & 2 & 0.55 & 0.55 & 0.55 & 2.00 & 50.00 & 50.00 & 50.00 \\
\hline combustibles & 7 & 3 & 0.08 & 0.08 & 0.10 & 2.00 & 2.00 & 3.10 & 3.10 \\
\hline metal & 3 & 2 & 0.25 & 0.25 & 0.25 & 2.00 & 2.00 & 2.00 & 2.00 \\
\hline glass & 2 & 1 & 0.69 & 0.69 & 0.69 & 1.35 & 2.00 & 2.00 & 2.00 \\
\hline inert & 2 & 1 & 0.12 & 0.12 & 0.12 & 1.06 & 2.00 & 2.00 & 2.00 \\
\hline $\operatorname{mix}$ & 10 & - & 0.00 & 0.00 & 0.02 & 0.32 & 0.46 & 0.77 & 0.80 \\
\hline
\end{tabular}

*) number of data points

${ }^{* *}$ ) number of values below the detection limit 
Value ranges for $\mathrm{Si}$

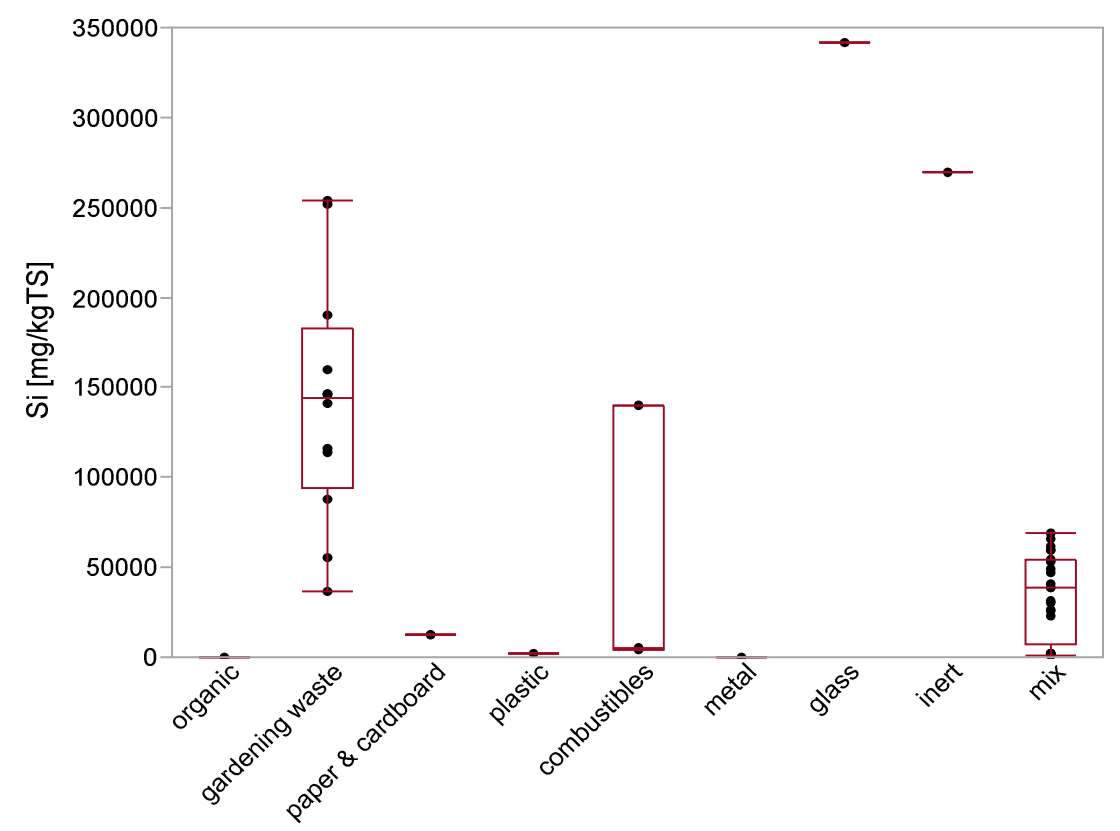

Waste Material Fractions

\section{Quantiles [mg/kgTS]}

\begin{tabular}{|c|c|c|c|c|c|c|c|c|c|}
\hline $\begin{array}{l}\text { Waste Material } \\
\text { Fraction }\end{array}$ & n_data* & $\mathrm{n}_{-}<\mathrm{DL}$ ** & Min & $10 \%$ & $25 \%$ & Median & $75 \%$ & $90 \%$ & $\operatorname{Max}$ \\
\hline organic & 1 & - & 488 & 488 & 488 & 488 & 488 & 488 & 488 \\
\hline food waste & - & - & - & - & - & - & - & - & - \\
\hline gardening waste & 12 & - & 37000 & 42400 & 94283 & 143733 & 182500 & 253663 & 254393 \\
\hline paper \& cardboard & 2 & - & 12200 & 12200 & 12200 & 12400 & 12600 & 12600 & 12600 \\
\hline composites & - & - & - & - & - & - & - & - & - \\
\hline plastic & 1 & - & 1670 & 1670 & 1670 & 1670 & 1670 & 1670 & 1670 \\
\hline combustibles & 3 & - & 3980 & 3980 & 3980 & 5110 & 140000 & 140000 & 140000 \\
\hline metal & 1 & - & 168 & 168 & 168 & 168 & 168 & 168 & 168 \\
\hline glass & 1 & - & 342000 & 342000 & 342000 & 342000 & 342000 & 342000 & 342000 \\
\hline inert & 1 & - & 270000 & 270000 & 270000 & 270000 & 270000 & 270000 & 270000 \\
\hline $\operatorname{mix}$ & 24 & - & 1447 & 1700 & 7443 & 38579 & 54480 & 64099 & 69200 \\
\hline
\end{tabular}

*) number of data points

$\left.{ }^{\star *}\right)$ number of values below the detection limit 


\section{Value ranges for Sn}

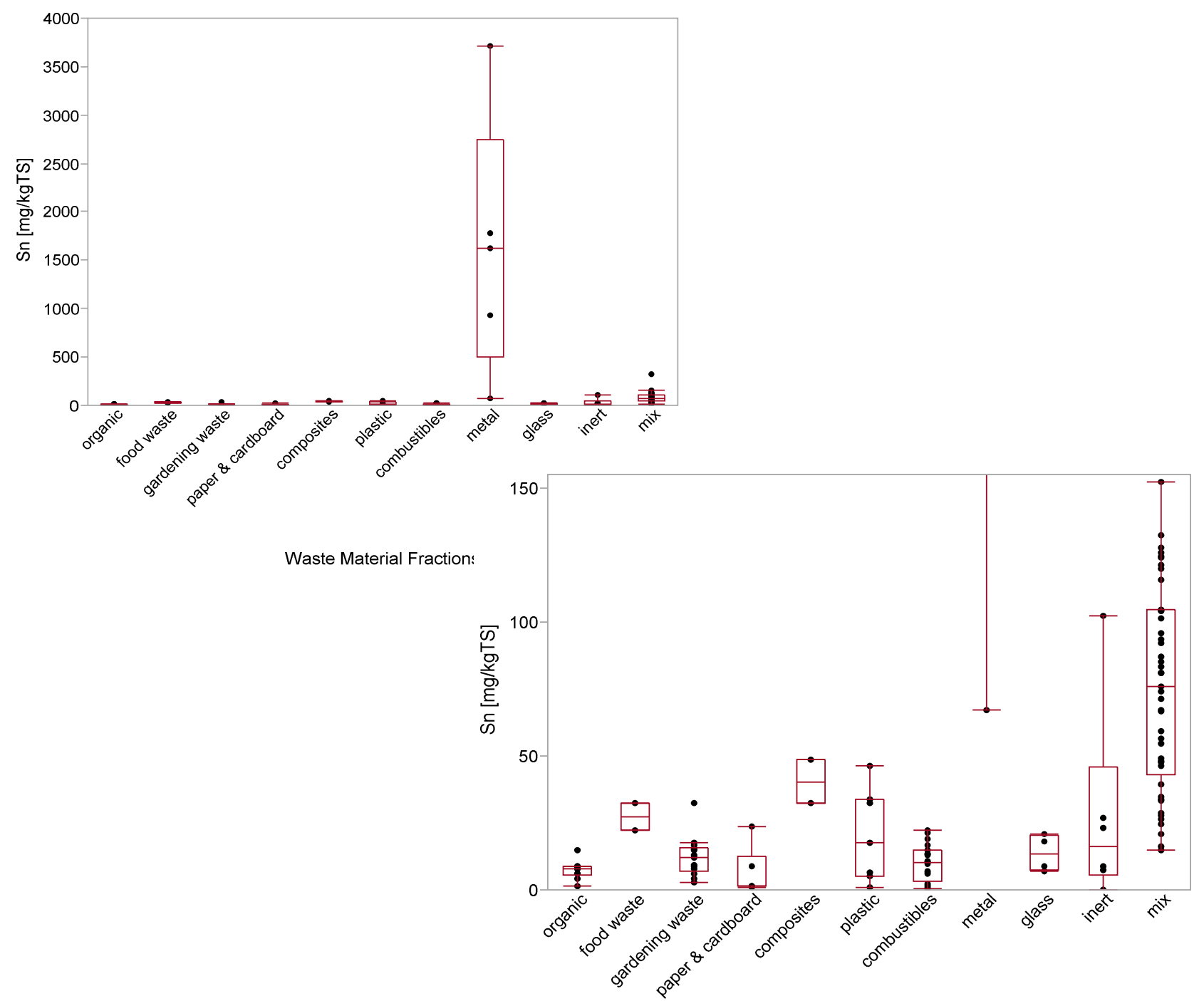

Quantiles [mg/kgTS]

Waste Material Fractions

\begin{tabular}{|c|c|c|c|c|c|c|c|c|c|}
\hline $\begin{array}{c}\text { Waste Material } \\
\text { Fraction }\end{array}$ & n_data* & $\mathrm{n}_{-}<\mathrm{DL} L^{* *}$ & Min & $10 \%$ & $25 \%$ & Median & $75 \%$ & $90 \%$ & $\operatorname{Max}$ \\
\hline organic & 10 & - & 1.2 & 1.5 & 5.6 & 8.0 & 8.9 & 14.1 & 14.7 \\
\hline food waste & 2 & - & 22.0 & 22.0 & 22.0 & 27.3 & 32.5 & 32.5 & 32.5 \\
\hline gardening waste & 13 & 4 & 3.0 & 3.4 & 7.1 & 12.0 & 15.9 & 26.4 & 32.2 \\
\hline paper \& cardboard & 6 & 1 & 1.0 & 1.0 & 1.2 & 1.4 & 12.6 & 23.5 & 23.5 \\
\hline composites & 2 & - & 32.3 & 32.3 & 32.3 & 40.4 & 48.5 & 48.5 & 48.5 \\
\hline plastic & 7 & 1 & 0.9 & 0.9 & 5.0 & 17.7 & 34.0 & 46.4 & 46.4 \\
\hline combustibles & 20 & 2 & 0.6 & 1.0 & 3.4 & 10.3 & 14.7 & 21.2 & 22.4 \\
\hline metal & 5 & 1 & 67.0 & 67.0 & 498.5 & 1620.0 & 2745.0 & 3710.0 & 3710.0 \\
\hline glass & 4 & - & 7.1 & 7.1 & 7.5 & 13.5 & 20.3 & 21.0 & 21.0 \\
\hline inert & 6 & - & 0.0 & 0.0 & 5.6 & 16.0 & 45.9 & 102.4 & 102.4 \\
\hline $\operatorname{mix}$ & 45 & - & 15.0 & 25.6 & 42.9 & 76.1 & 104.4 & 126.5 & 321.0 \\
\hline
\end{tabular}

*) number of data points

${ }^{* *}$ ) number of values below the detection limit 


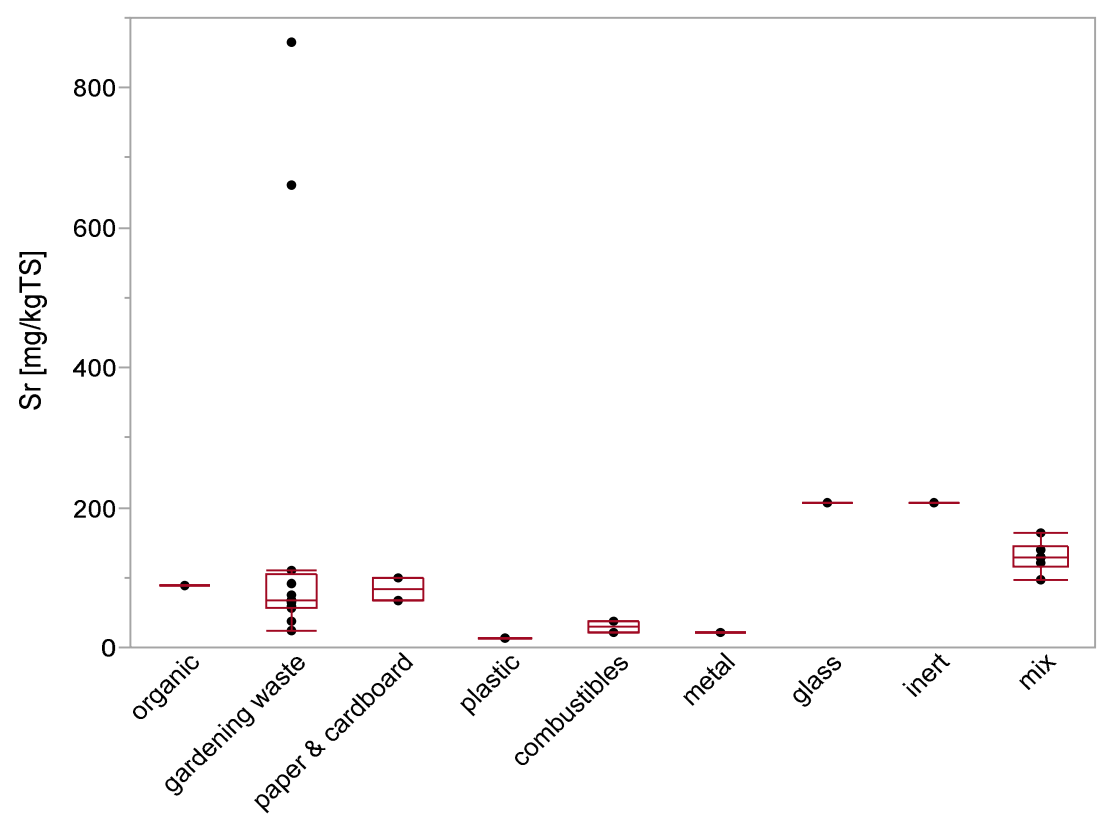

Waste Material Fractions

\section{Quantiles [mg/kgTS]}

\begin{tabular}{|c|c|c|c|c|c|c|c|c|c|}
\hline $\begin{array}{c}\text { Waste Material } \\
\text { Fraction }\end{array}$ & n_data* & $\mathrm{n}_{-}<\mathrm{DL}^{* *}$ & Min & $10 \%$ & $25 \%$ & Median & $75 \%$ & $90 \%$ & Max \\
\hline organic & 1 & - & 88.1 & 88.1 & 88.1 & 88.1 & 88.1 & 88.1 & 88.1 \\
\hline food waste & - & - & - & - & - & - & - & - & - \\
\hline gardening waste & 12 & - & 25.0 & 28.6 & 56.9 & 67.6 & 104.9 & 803.1 & 864.0 \\
\hline paper \& cardboard & 2 & - & 68.5 & 68.5 & 68.5 & 83.5 & 98.4 & 98.4 & 98.4 \\
\hline composites & - & - & - & - & - & - & - & - & - \\
\hline plastic & 1 & - & 13.3 & 13.3 & 13.3 & 13.3 & 13.3 & 13.3 & 13.3 \\
\hline combustibles & 2 & - & 20.9 & 20.9 & 20.9 & 29.0 & 37.0 & 37.0 & 37.0 \\
\hline metal & 1 & - & 21.5 & 21.5 & 21.5 & 21.5 & 21.5 & 21.5 & 21.5 \\
\hline glass & 1 & - & 208.0 & 208.0 & 208.0 & 208.0 & 208.0 & 208.0 & 208.0 \\
\hline inert & 1 & - & 208.0 & 208.0 & 208.0 & 208.0 & 208.0 & 208.0 & 208.0 \\
\hline $\operatorname{mix}$ & 6 & - & 97.0 & 97.0 & 115.0 & 130.0 & 145.0 & 163.0 & 163.0 \\
\hline
\end{tabular}

*) number of data points

$\left.{ }^{* *}\right)$ number of values below the detection limit 


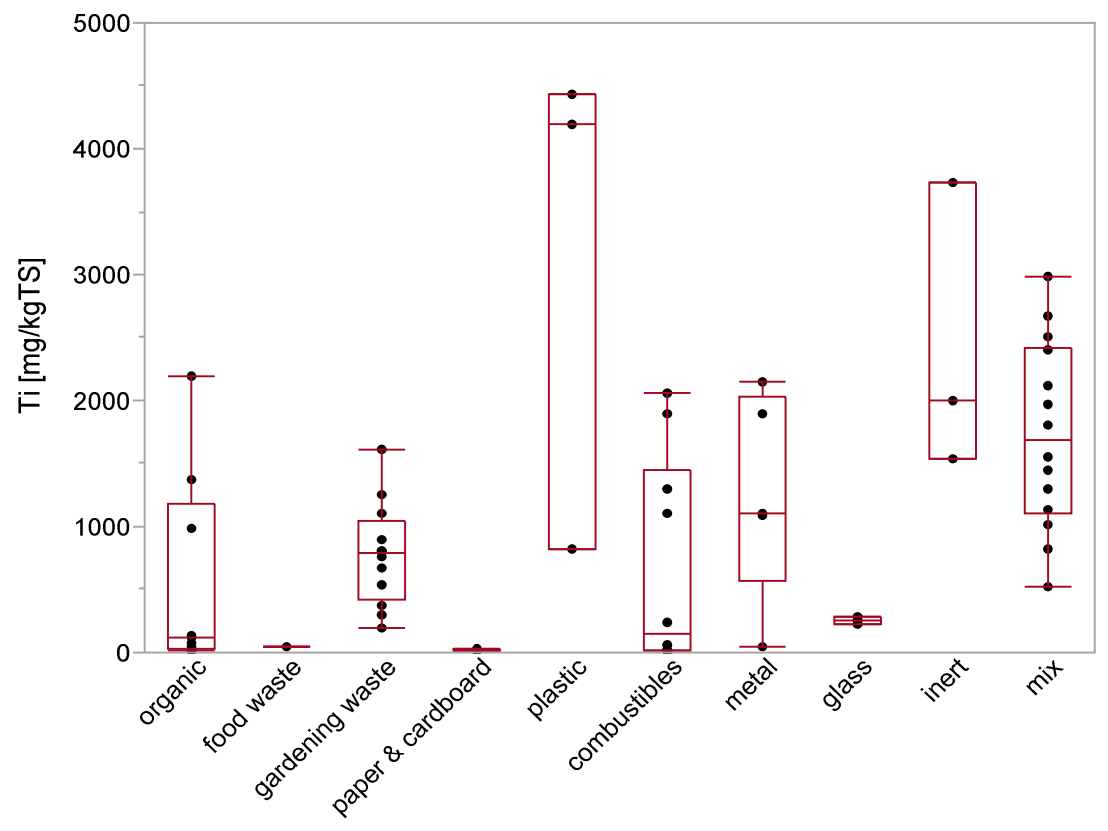

Waste Material Fractions

\section{Quantiles [mg/kgTS]}

\begin{tabular}{|c|c|c|c|c|c|c|c|c|c|}
\hline $\begin{array}{l}\text { Waste Material } \\
\text { Fraction }\end{array}$ & n_data* & $\mathrm{n}_{-}<\mathrm{DL} * *$ & Min & $10 \%$ & $25 \%$ & Median & $75 \%$ & $90 \%$ & Max \\
\hline organic & 9 & - & 8 & 8 & 34 & 120 & 1175 & 2200 & 2200 \\
\hline food waste & 1 & - & 45 & 45 & 45 & 45 & 45 & 45 & 45 \\
\hline gardening waste & 12 & - & 200 & 230 & 413 & 788 & 1050 & 1502 & 1607 \\
\hline paper \& cardboard & 4 & - & 10 & 10 & 10 & 13 & 30 & 34 & 34 \\
\hline composites & - & - & - & - & - & - & - & - & - \\
\hline plastic & 3 & - & 821 & 821 & 821 & 4200 & 4433 & 4433 & 4433 \\
\hline combustibles & 10 & - & 8 & 8 & 13 & 150 & 1450 & 2050 & 2067 \\
\hline metal & 5 & - & 46 & 46 & 568 & 1100 & 2025 & 2150 & 2150 \\
\hline glass & 3 & - & 230 & 230 & 230 & 250 & 289 & 289 & 289 \\
\hline inert & 3 & - & 1533 & 1533 & 1533 & 2000 & 3730 & 3730 & 3730 \\
\hline $\operatorname{mix}$ & 14 & - & 529 & 673 & 1101 & 1680 & 2425 & 2833 & 2990 \\
\hline
\end{tabular}

*) number of data points

$\left.{ }^{\star *}\right)$ number of values below the detection limit 
Value ranges for $V$

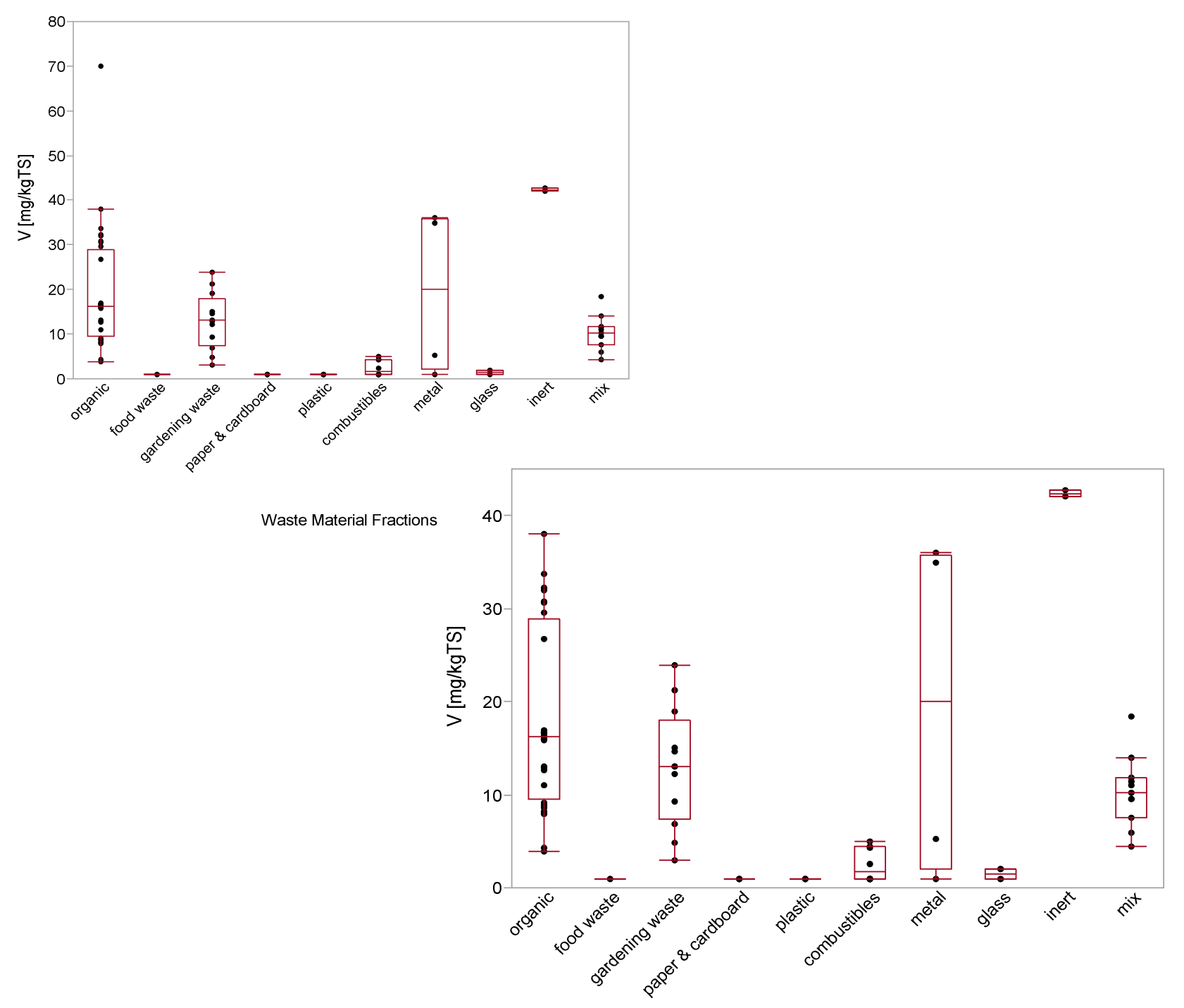

Quantiles [mg/kgTS]

Waste Material Fractions

\begin{tabular}{|c|c|c|c|c|c|c|c|c|c|}
\hline $\begin{array}{c}\text { Waste Material } \\
\text { Fraction }\end{array}$ & n_data* & $\mathrm{n}_{-}<\mathrm{DL}$ ** & Min & $10 \%$ & $25 \%$ & Median & $75 \%$ & $90 \%$ & $\operatorname{Max}$ \\
\hline organic & 32 & & 3.90 & 7.92 & 9.57 & 16.22 & 28.86 & 33.23 & 70.00 \\
\hline food waste & 1 & 1 & 1.00 & 1.00 & 1.00 & 1.00 & 1.00 & 1.00 & 1.00 \\
\hline gardening waste & 12 & & 3.00 & 3.54 & 7.44 & 13.03 & 18.00 & 23.08 & 23.85 \\
\hline paper \& cardboard & 2 & 2 & 1.00 & 1.00 & 1.00 & 1.00 & 1.00 & 1.00 & 1.00 \\
\hline plastic & 2 & 2 & 1.00 & 1.00 & 1.00 & 1.00 & 1.00 & 1.00 & 1.00 \\
\hline combustibles & 8 & 4 & 1.00 & 1.00 & 1.00 & 1.75 & 4.38 & 5.00 & 5.00 \\
\hline metal & 4 & 1 & 1.00 & 1.00 & 2.05 & 20.05 & 35.73 & 36.00 & 36.00 \\
\hline glass & 2 & 1 & 1.00 & 1.00 & 1.00 & 1.50 & 2.00 & 2.00 & 2.00 \\
\hline inert & 2 & & 42.00 & 42.00 & 42.00 & 42.35 & 42.70 & 42.70 & 42.70 \\
\hline $\operatorname{mix}$ & 11 & & 4.39 & 4.69 & 7.58 & 10.20 & 11.80 & 17.52 & 18.40 \\
\hline
\end{tabular}

*) number of data points

${ }^{* *}$ ) number of values below the detection limit 
Value ranges for $\mathrm{W}$

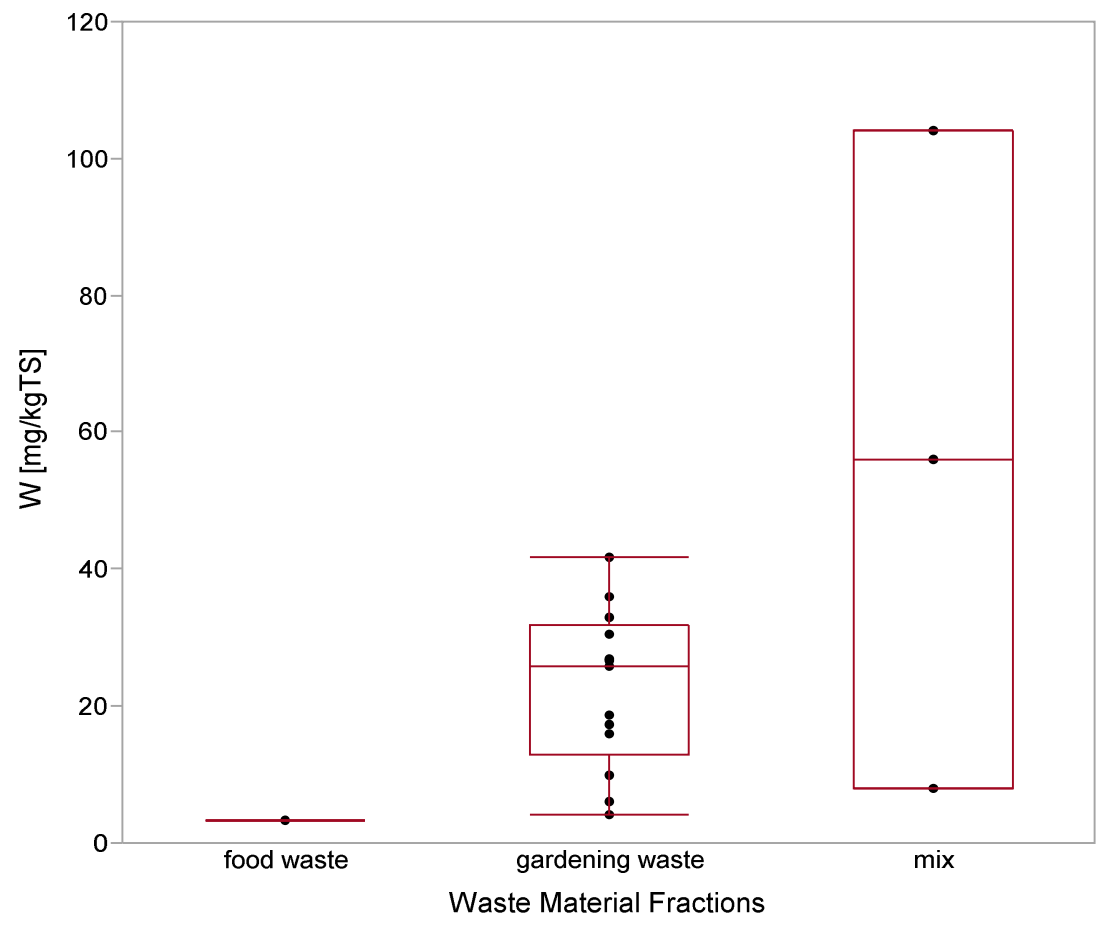

Quantiles [mg/kgTS]

Waste Material

\begin{tabular}{|c|c|c|c|c|c|c|c|c|c|}
\hline Fraction & n_data* & $\mathrm{n}_{-}<\mathrm{DL}$ ** & Min & $10 \%$ & $25 \%$ & Median & $75 \%$ & $90 \%$ & Max \\
\hline organic & - & - & - & - & - & - & - & - & - \\
\hline food waste & 1 & - & 3.3 & 3.3 & 3.3 & 3.3 & 3.3 & 3.3 & 3.3 \\
\hline gardening waste & 13 & 4 & 4.0 & 4.8 & 13.0 & 25.7 & 31.8 & 39.4 & 41.7 \\
\hline paper \& cardboard & - & - & - & - & - & - & - & - & - \\
\hline composites & - & - & - & - & - & - & - & - & - \\
\hline plastic & - & - & - & - & - & - & - & - & - \\
\hline combustibles & - & - & - & - & - & - & - & - & - \\
\hline metal & - & - & - & - & - & - & - & - & - \\
\hline glass & - & - & - & - & - & - & - & - & - \\
\hline inert & - & - & - & - & - & - & - & - & - \\
\hline $\operatorname{mix}$ & 3 & - & 8.0 & 8.0 & 8.0 & 56.0 & 104.0 & 104.0 & 104.0 \\
\hline
\end{tabular}

*) number of data points

$\left.{ }^{\star *}\right)$ number of values below the detection limit 


\section{Value ranges for $Y$}

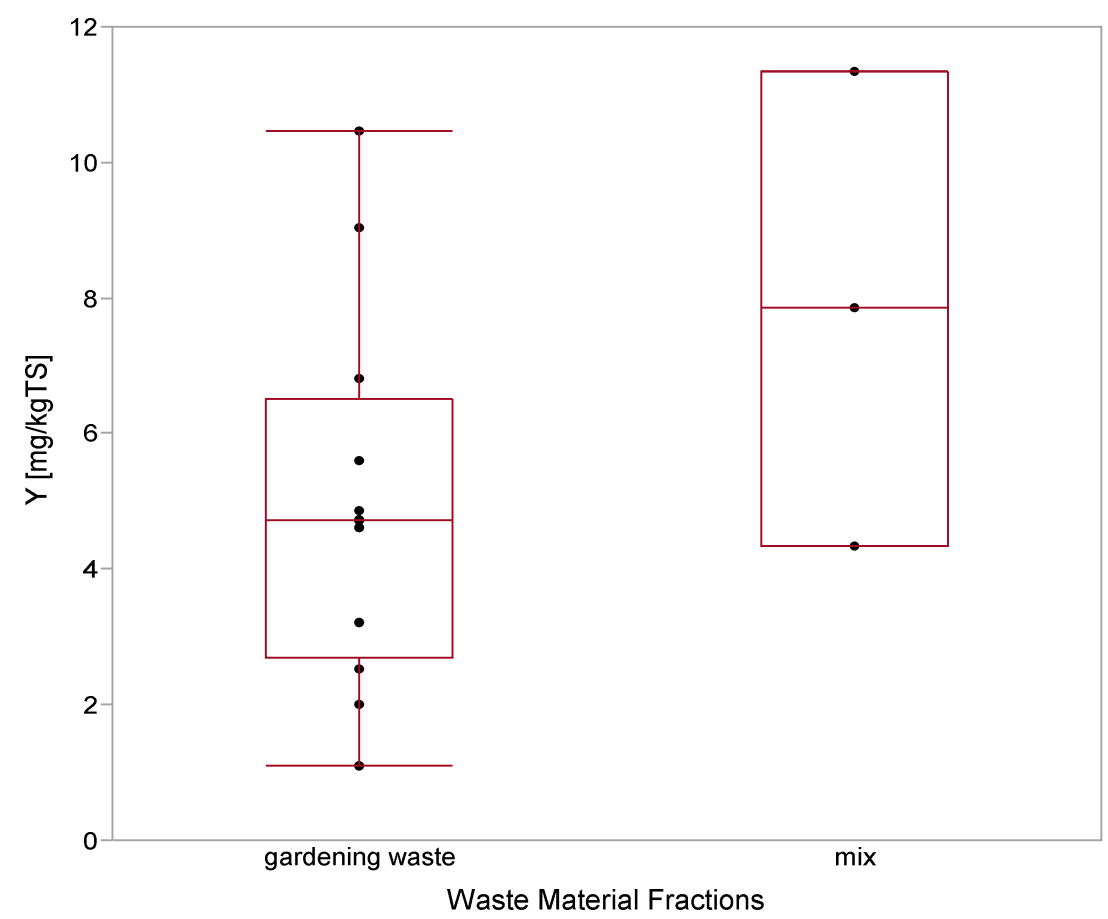

\section{Quantiles [mg/kgTS]}

\begin{tabular}{|c|c|c|c|c|c|c|c|c|c|}
\hline $\begin{array}{c}\text { Waste Material } \\
\text { Fraction }\end{array}$ & n_data* & $\mathrm{n}_{-}<\mathrm{DL}$ ** & Min & $10 \%$ & $25 \%$ & Median & $75 \%$ & $90 \%$ & $\operatorname{Max}$ \\
\hline organic & - & - & - & - & - & - & - & - & - \\
\hline food waste & - & - & - & - & - & - & - & - & - \\
\hline gardening waste & 12 & - & 1.1 & 1.4 & 2.7 & 4.7 & 6.5 & 10.0 & 10.5 \\
\hline paper \& cardboard & - & - & - & - & - & - & - & - & - \\
\hline composites & - & - & - & - & - & - & - & - & - \\
\hline plastic & - & - & - & - & - & - & - & - & - \\
\hline combustibles & - & - & - & - & - & - & - & - & - \\
\hline metal & - & - & - & - & - & - & - & - & - \\
\hline glass & - & - & - & - & - & - & - & - & - \\
\hline inert & - & - & - & - & - & - & - & - & - \\
\hline $\operatorname{mix}$ & 3 & - & 4.4 & 4.4 & 4.4 & 7.9 & 11.4 & 11.4 & 11.4 \\
\hline
\end{tabular}

*) number of data points

${ }^{* *}$ ) number of values below the detection limit 
Value ranges for $\mathrm{Zn}$

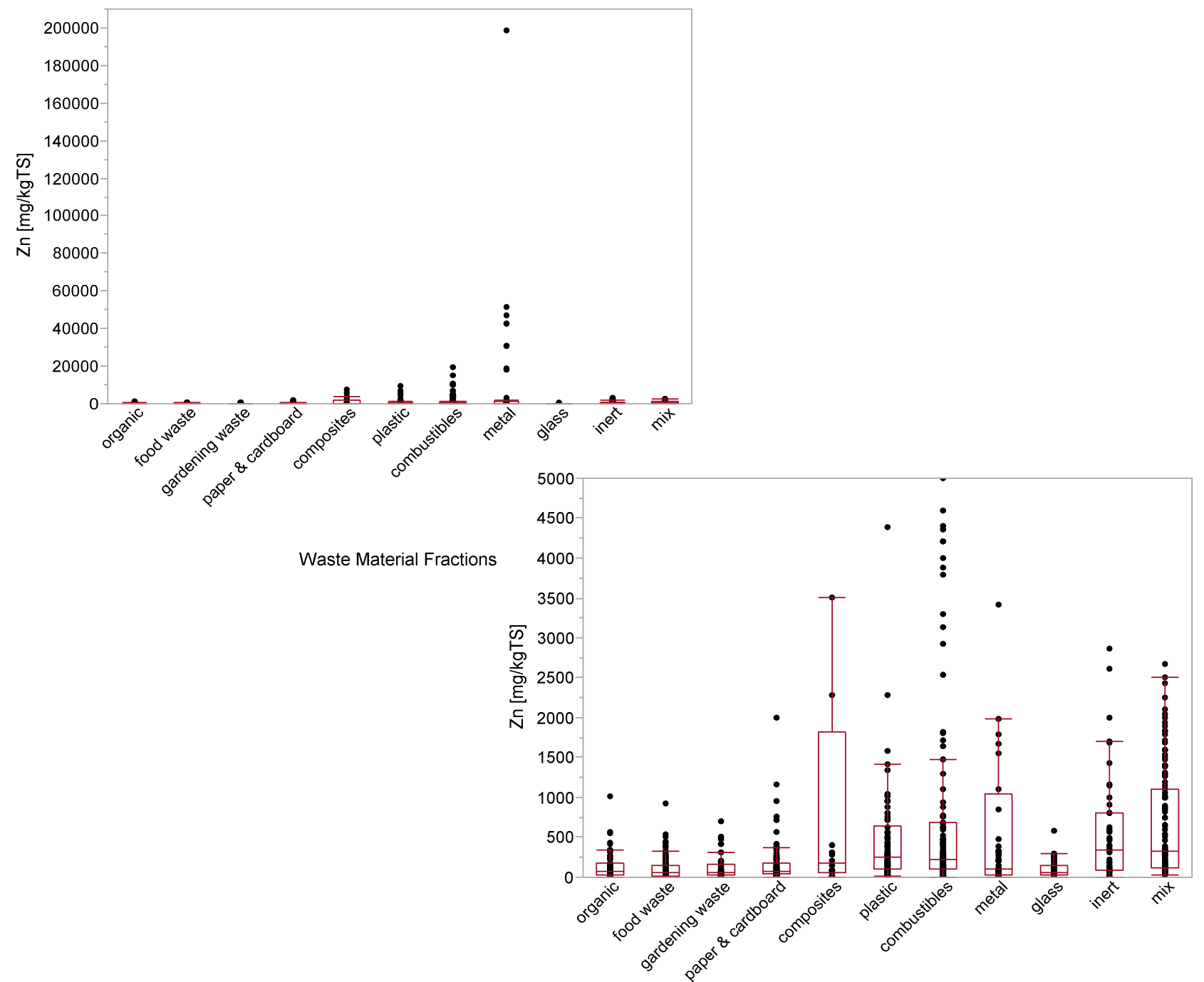

Quantiles [mg/kgTS]

Waste Material Fractions

Waste Material

\begin{tabular}{|c|c|c|c|c|c|c|c|c|c|}
\hline Fraction & n_data* & n_<DL** & Min & $10 \%$ & $25 \%$ & Median & $75 \%$ & $90 \%$ & Max \\
\hline organic & 63 & - & 0.0 & 28.3 & 35.7 & 75.0 & 182.0 & 346.0 & 1010.0 \\
\hline food waste & 123 & - & 0.0 & 7.5 & 12.1 & 56.0 & 144.6 & 295.8 & 931.4 \\
\hline gardening waste & 30 & - & 0.0 & 0.7 & 26.8 & 64.0 & 168.3 & 469.6 & 696.3 \\
\hline paper \& cardboard & 88 & - & 0.0 & 25.3 & 38.2 & 77.7 & 175.5 & 380.4 & 1997.0 \\
\hline composites & 16 & - & 3.7 & 9.0 & 66.1 & 176.0 & 1815.7 & 6153.9 & 7577.0 \\
\hline plastic & 82 & - & 14.3 & 43.5 & 107.1 & 258.7 & 647.3 & 1246.9 & 9204.0 \\
\hline combustibles & 133 & - & 0.0 & 40.8 & 101.2 & 230.0 & 719.5 & 4121.2 & 19475.0 \\
\hline metal & 64 & - & 0.0 & 0.0 & 28.3 & 103.5 & 1045.0 & 30446.0 & 199000.0 \\
\hline glass & 44 & - & 0.0 & 0.0 & 26.3 & 54.5 & 155.6 & 277.6 & 575.9 \\
\hline inert & 44 & - & 0.0 & 28.5 & 88.0 & 343.0 & 807.1 & 1693.2 & 2862.2 \\
\hline $\operatorname{mix}$ & 131 & - & 23.3 & 70.8 & 126.3 & 323.8 & 1100.0 & 1704.4 & 2677.0 \\
\hline
\end{tabular}

$\left.{ }^{*}\right)$ number of data points

$\left.{ }^{* *}\right)$ number of values below the detection limit 
Value ranges for $\mathrm{Zr}$

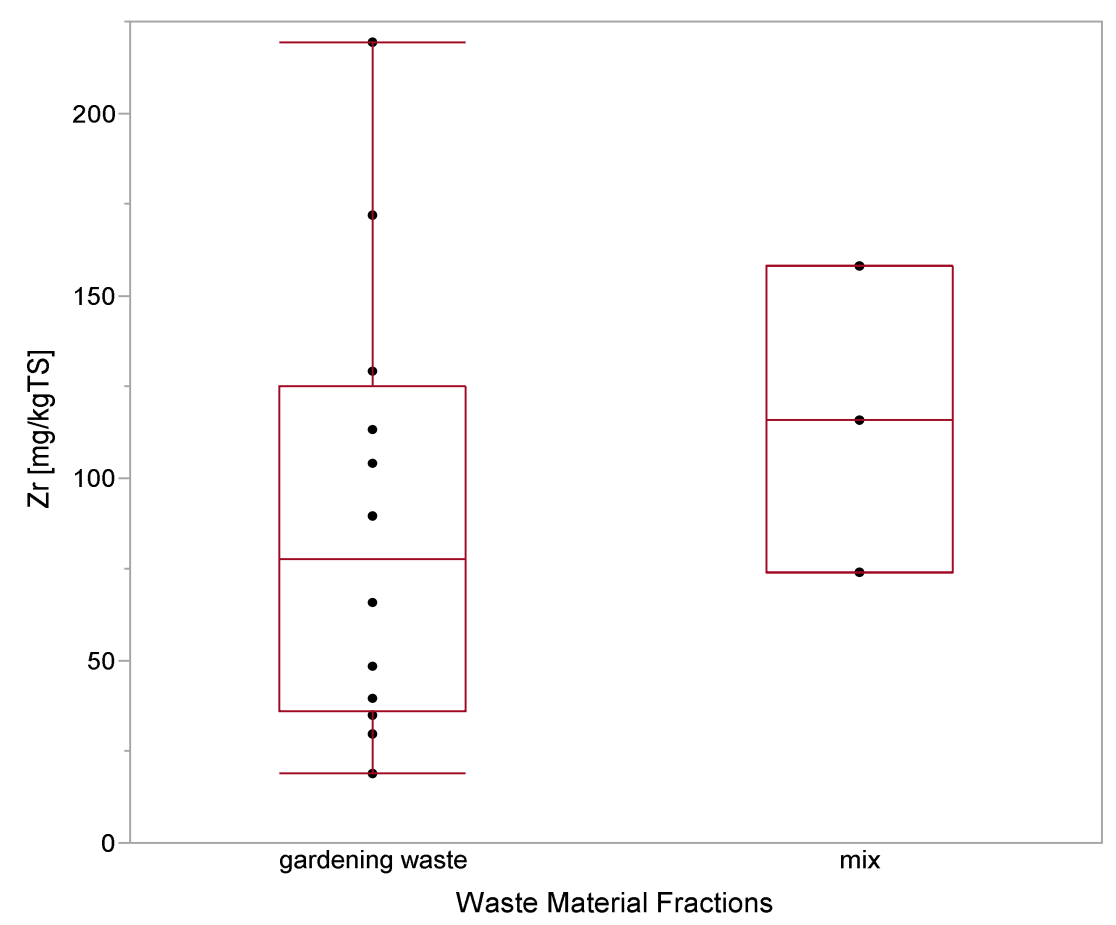

\section{Quantiles [mg/kgTS]}

\begin{tabular}{|c|c|c|c|c|c|c|c|c|c|}
\hline $\begin{array}{c}\text { Waste Material } \\
\text { Fraction }\end{array}$ & n_data* & $\mathrm{n}_{-}<\mathrm{DL}$ ** & Min & $10 \%$ & $25 \%$ & Median & $75 \%$ & $90 \%$ & Max \\
\hline organic & - & - & - & - & - & - & - & - & - \\
\hline food waste & - & - & - & - & - & - & - & - & - \\
\hline gardening waste & 12 & - & 19 & 22 & 36 & 78 & 125 & 205 & 219 \\
\hline paper \& cardboard & - & - & - & - & - & - & - & - & - \\
\hline composites & - & - & - & - & - & - & - & - & - \\
\hline plastic & - & - & - & - & - & - & - & - & - \\
\hline combustibles & - & - & - & - & - & - & - & - & - \\
\hline metal & - & - & - & - & - & - & - & - & - \\
\hline glass & - & - & - & - & - & - & - & - & - \\
\hline inert & - & - & - & - & - & - & - & - & - \\
\hline $\operatorname{mix}$ & 3 & - & 74 & 74 & 74 & 116 & 158 & 158 & 158 \\
\hline
\end{tabular}

$\left.{ }^{*}\right)$ number of data points

$\left.{ }^{\star *}\right)$ number of values below the detection limit 